

\section{Globalization and Capitalist Geopolitics}

Globalization and Capitalist Geopolitics is concerned with the growth of transnational corporate power against the backdrop of the decline of the West and the struggle by non-Western states to challenge and overcome domination of the rest of the world by the West. At the centre of the study is the problematic status of the US as guarantor of global security and imperial nation in decline. The declining power of America in a multipolar world places a question mark under the future of Western leadership of globalization.

Woodley interrogates the structure of contemporary world order and examines competing approaches to globalization and global capitalism in international relations and international political economy. He engages with key scholars in the field, and provides an authoritative yet accessible commentary on debates on globalization and geopolitics in the wake of the global financial crisis.

In a period of increasing geopolitical insecurity and geoeconomic transition, this book is a major contribution to the debate on globalization. It is a key resource for students and scholars seeking a deeper understanding of the historical and economic determinants of neoliberal capitalism, the impact of global economic convergence for Western economies, and the implications of globalization for the reconstruction of contemporary world order.

Daniel Woodley teaches politics at DLD College in London. He is the author of numerous articles and textbooks on ideology and political theory, including Fascism and Political Theory (2010), also published by Routledge. 


\section{Rethinking Globalizations}

Edited by Barry K. Gills, University of Helsinki, Finland and Kevin Gray University of Sussex, UK.

This series is designed to break new ground in the literature on globalization and its academic and popular understanding. Rather than perpetuating or simply reacting to the economic understanding of globalization, this series seeks to capture the term and broaden its meaning to encompass a wide range of issues and disciplines and convey a sense of alternative possibilities for the future.

1. Whither Globalization?

The vortex of knowledge

and globalization

James H. Mittelman

2. Globalization and

Global History

Edited by Barry K. Gills and

William R. Thompson

3. Rethinking Civilization

Communication and terror in

the global village

Majid Tehranian

4. Globalization and Contestation

The new great counter-movement

Ronaldo Munck

5. Global Activism

Ruth Reitan

6. Globalization, the City and Civil Society in Pacific Asia

Edited by Mike Douglass,

K.C. Ho and Giok Ling Ooi
7. Challenging Euro-America's Politics of Identity

The return of the native Jorge Luis Andrade Fernandes

8. The Global Politics of Globalization "Empire" vs "Cosmopolis" Edited by Barry K. Gills

9. The Globalization of Environmental Crisis Edited by Jan Oosthoek and Barry K. Gills

10. Globalization as Evolutionary Process Modeling global change Edited by Geroge Modelski, Tessaleno Devezas and William R. Thompson

11. The Political Economy of Global Security

War, future crises and changes in global governance Heikki Patomäki 
12. Cultures of Globalization

Coherence, hybridity,

contestation

Edited by Kevin Archer,

M. Martin Bosman,

M. Mark Amen and Ella Schmidt

13. Globalization and the Global Politics of Justice

Edited by Barry K. Gills

14. Global Economy Contested Power and conflict across the international division of labor Edited by Marcus Taylor

15. Rethinking Insecurity, War and Violence

Beyond savage globalization?

Edited by Damian Grenfell and Paul James

16. Recognition and Redistribution Beyond international development Edited by Heloise Weber and Mark T. Berger

17. The Social Economy

Working alternatives in a globalizing era

Edited by Hasmet M. Uluorta

18. The Global Governance of Food Edited by Sara R. Curran, April Linton, Abigail Cooke and Andrew Schrank

19. Global Poverty, Ethics and Human Rights

The role of multilateral organisations Desmond McNeill and Asunción Lera St. Clair
20. Globalization and Popular Sovereignty

Democracy's transnational dilemma

Adam Lupel

21. Limits to Globalization North-South divergence William R. Thompson and Rafael Reuveny

22. Globalisation, Knowledge and Labour

Education for solidarity within spaces of resistance Edited by Mario Novelli and Anibel Ferus-Comelo

23. Dying Empire

U.S. imperialism and global resistance Francis Shor

24. Alternative Globalizations An integrative approach to studying dissident knowledge in the global justice movement S. A. Hamed Hosseini

25. Global Restructuring, Labour and the Challenges for Transnational Solidarity Edited by Andreas Bieler and Ingemar Lindberg

26. Global South to the Rescue Emerging humanitarian superpowers and globalizing rescue industries Edited by Paul Amar

27. Global Ideologies and Urban Landscapes Edited by Manfred B. Steger and Anne McNevin 
28. Power and

Transnational Activism

Edited by Thomas Olesen

29 Globalization and Crisis Edited by Barry K. Gills

30. Andre Gunder Frank and Global Development

Visions, remembrances

and explorations

Edited by Patrick Manning and Barry K. Gills

31. Global Social Justice

Edited by Heather Widdows and Nicola J. Smith

32. Globalization, Labor Export and Resistance

A study of Filipino migrant domestic workers in global cities.

Ligaya Lindio-McGovern

33. Situating Global Resistance Between Discipline and Dissent Edited by Lara Montesinos Coleman and Karen Tucker

34. A History of World Order and Resistance

The Making and Unmaking of Global Subjects

André C. Drainville

35. Migration, Work and Citizenship in the New Global Order Edited by Ronaldo Munck, Carl-Ulrik Schierup and Raúl Delgado Wise
36. Edges of Global Justice

The World Social Forum and

Its 'Others'

Janet Conway

37. Land Grabbing and Global Governance

Edited by Matias E. Margulis,

Nora McKeon and

Saturnino Borras Jr.

38. Dialectics in World Politics

Edited by Shannon Brincat

39. Crisis, Movement, Management: Globalising Dynamics

Edited by James Goodman and Jonathan Paul Marshall

40. China's Development

Capitalism and Empire

Michel Aglietta and Guo Bai

41. Global Governance and NGO Participation

Charlotte Dany

42. Arab Revolutions and World Transformations

Edited by Anna M. Agathangelou and Nevzat Soguk

43. Global Movement Edited by Ruth Reitan

44. Free Trade and the Transnational Labour Movement Edited by Andreas Bieler, Bruno Ciccaglione, John Hilary and Ingemar Lindberg 
45. Counter-Globalization and Socialism in the 21st Century

The Bolivarian Alliance for the Peoples of our America

Thomas Muhr

46. Global Civil Society and Transversal Hegemony

The Globalization-Contestation

Nexus

Karen M. Buckley

47. Contentious Agency and Natural Resource Politics

Markus Kröger

48. Social Movements, the Poor and the New Politics of the Americas Edited by Håvard Haarstad, Mark Amen and Asuncion Lera St Clair

49. Development in an Era of Neoliberal Globalization Edited by Henry Veltmeyer

50. The State-Capital Nexus in the Global Crisis

Rebound of the Capitalist State Edited by Bastiaan van Apeldoorn, Naná de Graaff and Henk $W$. Overbeek

51. From Empires to Imperialism The State and the Rise of Bourgeois Civilisation Boris Kagarlitsky, translated by Renfrey Clarke

52. Global Justice and the Politics of Information The Struggle over Knowledge Sky Croeser
53. Labour and Development in East Asia

Social Forces and Passive Revolution Kevin Gray

54. Global Capitalism and Transnational Class Formation Edited by Jason Struna

55. Rethinking Border Control for a Globalizing World

A Preferred Future

Edited by Leanne Weber

56. Global Governance, Legitimacy and Legitimation

Edited by Magdalena Bexell

57. Critical Rationalism and Globalisation Towards the Sociology of the Open Global Society Masoud Mohammadi Alamuti

58. Globalisation Development and Social Justice

A Propositional

Political Approach

Edited by Ann El-Khoury

59. Globalization: The Career of a Concept

Edited by Manfred Steger and Paul James

60. Globalization and Capitalist Geopolitics

Sovereignty and state power in a multipolar world Daniel Woodley 



\section{Globalization and Capitalist Geopolitics}

Sovereignty and state power in a multipolar world

\section{Daniel Woodley}


First published 2015

by Routledge

2 Park Square, Milton Park, Abingdon, Oxon OX14 4RN

and by Routledge

711 Third Avenue, New York, NY 10017

Routledge is an imprint of the Taylor \& Francis Group, an informa business

(C) 2015 Daniel Woodley

The right of Daniel Woodley to be identified as the author of this work has been asserted by him in accordance with the Copyright, Designs and Patent Act 1988.

All rights reserved. No part of this book may be reprinted or reproduced or utilised in any form or by any electronic, mechanical, or other means, now known or hereafter invented, including photocopying and recording, or in any information storage or retrieval system, without permission in writing from the publishers.

Trademark notice: Product or corporate names may be trademarks or registered trademarks, and are used only for identification and explanation without intent to infringe.

British Library Cataloguing in Publication Data

A catalogue record for this book is available from the British Library

Library of Congress Cataloging in Publication Data

A catalog record for this book has been requested

ISBN: 978-0-415-74505-5 (hbk)

ISBN: 978-1-315-79816-5 (ebk)

Typeset in Times New Roman

by Taylor \& Francis Books

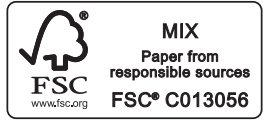

Printed and bound in Great Britain by TJ International Ltd, Padstow, Cornwall 


\section{Contents}

List of tables $\quad \mathrm{x}$

Preface xiii

Acknowledgements xvi

1 Globalization and world order 1

2 Capitalist sovereignty 22

3 Corporate globalization $\quad 47$

4 The state form of transnational capital 74

5 The crisis of Western economic power 106

6 Towards a posthegemonic global growth system 141

$\begin{array}{lll}7 & \text { Capitalist geopolitics } & 175\end{array}$

$\begin{array}{ll}\text { Abbreviations } & 216\end{array}$

Bibliography 218

$\begin{array}{ll}\text { Index } & 267\end{array}$ 


\section{List of tables}

6.1 Multidimensional polarity index, 2004-08 average 157

6.2 Share of world population and global GDP, 1950-2008 159

6.3 GDP and GDP per capita in developing countries and the world economy (in current prices and at market exchange rates) 
For Arkady 



\section{Preface}

In an age of increasing uncertainty and risk, students of international relations are struggling to describe and explain the dissonance between global politics as the study of globalization and transnational governance, and geopolitics as the study of conflict between competing regional blocs or 'great spaces'. This has led many commentators to theorize a new multipolar order, as US leadership falters and emerging powers challenge Western hegemony. It has also led some commentators to retreat from theories of cosmopolitanism and complex interdependence back to classical theories of geopolitics which resituate international conflict in the immutable logic of geographical determinism as if the internationalization of capitalist relations of power instantiated by corporate globalization - which has integrated former communist states and developing economies into the structures of neoliberal global capitalism - had not taken place.

To explain the material determinants of contemporary geopolitics a new approach is required based on insights drawn from critical political economy. Although the US continues to preside over a quasi-imperial system of power based on global military preponderance and financial statecraft, and is reluctant to recognize the realities of global economic convergence, the age of imperial state hegemony is giving way to a new international economic order characterized by capitalist sovereignty and the competition between regional/ transnational concentrations of power for geopolitical security. From this perspective, contemporary geopolitics should be understood as a transnational strategic practice employed by powerful industrialized economies which mirrors predatory corporate rivalry for control over global markets, reproducing the structural conditions for corporate power through the transnational state form of capital. The emerging conflict between the West and 'Hobbesian contenders' such as Russia and China is less a geopolitical struggle between 'great spaces' or a 'clash of civilizations', as some commentators have suggested, than a competition between alternative models of capitalist development and capitalist finance in a multipolar world order in which transnational corporate power is the defining feature of human social organization.

The text outlines a Marxian approach to international political economy, examining the debate on globalization and geopolitics from the perspective of 
capitalist sovereignty. Capitalist sovereignty resolves at a transnational level the tension between equal juridical sovereignty and material inequality in an international political economy mediated by the oligarchic power of finance. Neoliberal global capitalism is defined by a transition from imperial state hegemony to transnational corporatism in a decentred world-system where the determining logic of capital is organized and diffused through structures of economic integration, securitization and financial surveillance necessitated by the growing internationalization of production, trade and investment. This geoeconomic order has its origins in European imperialism, yet the logic of globalization lies not in empire but in the directionless expansion of capital as a mode of power. The transnationally constituted power of financial capital is valorized politically through the global state form of capital which transcends the Hobbesian antinomy of disorder and territorial sovereignty in an attempt to escape traditional categories of territorial political authority. But while the liberal international order founded by the West has irreversibly transformed international political economy, the institutional and ideological form of globalization is now evolving beyond the geopolitical control of the West as new concentrations of financial and economic power are established in Asia and beyond, challenging the transnationally constituted geopolitical power of the Anglosphere for the first time in modern history.

Chapter 1 examines the changing structure of the world-system in an age of transnational corporate power - a transformation which is redefining the international political economy of world order. Chapter 2 then elaborates a theory of capital as the 'objective subject' of a new global sociality founded upon the directionless self-expansion and valorization of value. As a selfexpanding mode of power, capital is structured through the corporate social organization of commodity-producing societies (Chapter 3) and mediated through the transnational state form of financial capital (Chapter 4). Following this, Chapter 5 assesses the extent to which the accumulation crisis of western capitalism is undermining the leadership of the US in the global economy. It suggests that the failure of the Anglo-Saxon nations to accept their declining power in the international system and restructure their indebted economies is leading the West towards financial and monetary collapse as rising powers in Eurasia prepare to move towards a post-US-centric international monetary system.

Chapter 6 then investigates the new economic regionalism in international relations, focusing on the growth of emerging markets in Asia and Latin America as regional economies seek greater autonomy from the constraints of western international financial institutions. Finally, Chapter 7 examines the counterhegemonic challenge to the global monetary power of the West represented by the rise of China and resurgence of Russia as two principal revisionist states in the world-system. While China has thus far refused to aggressively balance the US, restricting itself to the formation of commercial structures and financial institutions to accommodate its expanding economic 
footprint, Russia has made clear it seeks to replace the petrodollar with a new global energy trading system and to promote greater interregionalism in the greater Eurasian space. This lies at the heart of the present confrontation between the US and Russia in Ukraine, a conflict designed to force European powers to choose between a transatlantic past and a Eurasian future as the US pivots towards East Asia and turns to address its approaching domestic political crises. 


\section{Acknowledgements}

First and foremost I would like to thank my partner and soul mate, Dr Wanda Wyporska, for giving me time to complete the research for this book. Without this gift, and her emotional and intellectual support, it might not have been finished. I would also like to thank Dr Gregory Slysz, Dr Miroslav Imbrisevic and Richard Milner for critically reading sections of the manuscript and offering useful suggestions, as well as Charles Abboud for so many invaluable discussions over the years. In addition, I would like to thank my students for putting up with my endless digressions on international political economy. Their input has been brilliant, helping me to sharpen arguments and question received assumptions. Finally, I would like to thank Professor Deepak Nayyar at the Jawaharlal University in New Delhi for allowing me to reprint data from his splendid work on emerging market economies, and the World Bank for giving permission to reprint data from one of their publications. Needless to say, I alone am responsible for any errors or omissions in the text. 


\section{Globalization and world order}

\section{Introduction}

The following study is concerned with the tension between globalization and geopolitics in a multipolar world order where the balance of global economic power is shifting as emerging capitalist states challenge the established financial and political domination of the West in international politics. The aim of the text is to reconnect the twin logics of capital and territoriality separated in Marxist and neorealist international political economy (IPE) through the idea of capitalist sovereignty, and to assess the implications of corporate globalization for the economic security and future prosperity of the West as that region of the world where rationalization traditionally has been most advanced (Stiegler 2010). Globalization is proceeding in a world characterized by cooperative and antagonistic relations between states and regional organizations of states which, despite growing pressure to comply with the norms of global governance, continue to compete for resources and regional dominance. However, while geoeconomic rivalry remains an essential feature of international relations - exemplified by the conflict between the West and the BRICS (Brazil, Russia, India, China and South Africa) economies over the future of the international monetary system - imperialist geopolitics as traditionally practised by hegemonic states is increasingly inconsistent with the transnational organization of trade, investment and production in a post-UScentric global economy in which the balance of economic power is shifting towards Asia. International relations between states and regional economic formations are determined less by territorial fixity and interimperial rivalry than by the overarching logic of accumulation organized through transnational commodity chains, not merely between advanced economies in the 'Lockean heartland', but between advanced economies and 'Hobbesian contenders' seeking to challenge the prerogative right of the West to determine the geopolitical and ideological form of global capitalism in a posthegemonic international system.

The thesis of capitalist sovereignty places the value form-determined relation of power at the centre of theoretical analysis. It is necessary to move beyond well-meaning critiques of the International Monetary Fund (IMF), 


\section{Globalization and world order}

World Bank or World Trade Organization (WTO) as agencies of the 'collective imperialism of the Triad' (Amin 2011) to understand the transnationalization of corporate power and foreign direct investment (FDI) outside the core capitalist economies where accumulation has traditionally been concentrated. While capital is supported by state actors which sustain conditions of accumulation, and while rivalry between a 'plurality of centres of accumulation remains a constitutive dimension of contemporary capitalism' (Callinicos 2002: 262) - and is often organized directly by states through sovereign wealth funds (Woolridge 2012) - it is power over global markets which endows financial capital with the capacity to determine frameworks of global extraction and accumulation, and to consolidate and extend the structural asymmetries of power that sustain transnational corporatism.

As Marx argued in Grundrisse, the 'tendency to create the world market is directly given in the concept of capital itself. Every limit is a barrier to be overcome' (Marx 1973: 408). In the political economy of globalization capital assumes the role of the objective subject: the sole aim capital is capable of realizing is self-augmentation through the valorization of value - not simply the blind accumulation of surplus-value through the direct exploitation of commodified labour-power in spatially bounded production sites, but the exponential growth of synthetic market values through the growth of capitalist finance as an end in itself rather than an instrument for the development of production and commerce. Financial capital is managed for the benefit of transnational investors - an interlocking network of corporate-state elites centred in North America, Europe and Asia whose class profile is fragmented but whose structural power is articulated through a transnationally constituted geopolitics that transcends the territorially embedded interests of national capitals. As transnationally constituted power, global finance structures capital flows, patterns of cross-border investment and commodity production, aligning foreign and security policy between economies in the capitalist core in a hierarchical system of cooperation and competition with peripheral economies.

This process of transnationalization and world modernization - always partial, uneven and incomplete, has implications for the structural logic of anarchy in international relations (IR) by creating incentives for multilateralism, yet globalization simultaneously creates new sources of conflict between transnational capital and regional power centres along the arc of geopolitical insecurity from Central Asia to the Middle East and North Africa (MENA), as advanced capitalist economies try to exploit, yet struggle to contain the legacies of, weak state formation in the periphery (Dannreuther 2013), to limit the rise of an independent Eurasian alliance system resistant to Western geopolitical intervention, to constrain China's diplomatic and economic penetration of pro-Western client states in Asia, Latin America and the Middle East, and to suppress counterhegemonic nationalist and religious movements by direct force. ${ }^{1}$ Despite liberal-cosmopolitan dreams of a 'global commonwealth of citizens' (Archibugi 2008), the 
willingness of Western corporate-state elites to manage globalization through transnational institutions is diminished by their refusal to recognize at an institutional level the changing balance of power in the world economy and the structural imbalances created by the fiscal and monetary crisis of the American state.

To make sense of capitalist sovereignty in a world structured by nationstates, it is necessary to theorize transnational corporatism against the backdrop of debates in IR and the 'relative decline' of the West. As Robinson argues, the dynamic force of global capital and the relative economic power of capitalist nations are increasingly determined by forces and institutions 'grounded in the global system rather than the interstate system' (Robinson 2004a: 56). Yet despite belated recognition of the impact of global capitalism on international politics, IR remains not only epistemologically confined in state-centric theory (methodological nationalism), but fails to deal adequately with three themes in the political economy of world order, namely the consolidation of corporate power in the transition from liberal to postliberal capitalism, the rise of a transnational security system consistent with the defence of corporate property, and the challenge posed by the economic geography of regionalism to the financial and geopolitical power of the West.

Contrary to the claims of cosmopolitan theorists, a world federation founded on shared commitment to liberal universalism is implausible, not merely because revisionist states such as Russia and China favour mercantilism and question Anglo-American leadership of the global economy, but because transnational corporatism itself is incompatible with democratic authority and legal accountability. The pressure to comply with rules-based trade compels all states to adapt to 'complex interdependence' in their own interests, as neoliberal institutionalists correctly argue; yet corporate financial capital (a private mode of power engineered for the pecuniary gain of investors) and democracy (a public mode of decision making for resolving distribution issues in sovereign polities) are essentially antithetical: far from empowering states to establish a rational basis for multilateral co-governance (synarchy), international legal agreements such as the proposed Transatlantic Trade and Investment Partnership (TTIP) between the European Union (EU) and the North American Free Trade Agreement (NAFTA) threaten to restrict market competition and limit the capacity of states to enact legislation to regulate corporations, thereby consolidating the economic and political power of the transnational investor class - while potentially also excluding Russian firms from EU markets.

Dominated by Anglo-American scholarship, mainstream IR has been relatively slow to explore these themes, for while globalization promotes trade and investment and advances 'synarchic' properties in the world-system (cogovernance between states and open interregionalism), the uneven and combined development of global capitalism has produced a 'coexistence of multiplicity' in the international system in which no single economy or economic model is triumphant. In addition, while the rapid development of capitalist forms in 


\section{Globalization and world order}

emerging economies is challenging Western economic leadership, the insertion of core and peripheral economies into structures of global governance - whose agendas are co-determined by corporate power - is problematizing the historic status of the unified state actor as the epistemological ground of IR.

Although globalization requires the national state form of capital to reproduce non-capitalist social structures of accumulation (Kotz 1994, 2007), it simultaneously creates unstable dynamics between economies at different stages of development in a 'heterogeneous interstate system that yields an endless proliferation of transnational actors and identities' (Wilson 2009: 35). This entails not simply the intrusion of 'irrational' identities and practices in an otherwise 'rational' world system formed during five centuries of Western hegemony, but a rupture in the linear modernizing dynamic of liberal universalism characterized by a jettisoning of the growth paradigm of industrialism and progress and a reversion to non-capitalist informal economy/ decommodified labour-power across disaggregated and spatially distributed supply chains in emerging market economies where local firms employing billions of low-paid workers in 'special production zones' compete for contracts to supply global brands (cf. Sanyal 2007).

The securitization necessary to sustain this global accumulation regime has also contributed to the development of 'parapolitics', namely the nexus of transnational power interests that flourishes along the interstices between formal government, the 'deep state' and organized crime which is dyadic to corporate power as a form of globalized predatory entrepreneurialism (Wilson 2009; cf. Deneault 2010; Napoleoni 2009; Blakely 2009). Wilson (2012) derives the deep state from the structure of the liberal 'dual state' which represses and conceals political conflict and which sustains the bourgeois illusion of a rational 'risk-free' business civilization but which cannot overcome its genesis in the originary violence of state formation. In the post-9/11 era the deep state is finally revealed for what it is: the crimogenic dimension of liberal order. Parapolitics, in this sense, is also the 'study of criminal sovereignty, of criminals behaving as sovereigns and sovereigns behaving as criminals in a systematic way' (Cribb 2009: 8).

A second theme of the text is the present contradictory status of the US as self-appointed guarantor of global security and superpower in decline - the 'indispensible nation' whose control over international finance and global security have been severely tested by the failure of the Iraq war and the impact of the global financial crisis (Xinbo 2010). To understand the condition of the last superpower, it is necessary to consider the academic controversy between unipolar optimists - apologists for Pax Americana under a 'liberal Leviathan' (Ikenberry 2011; Kindleberger 1981) - and unipolar pessimists - neorealist and neo-Marxist critics of US foreign policy who reject hegemonic stability theory and/or emphasize the inherently conflictual character of attempts to establish an enduring global hegemony (Kennedy 1987; Mearsheimer 2001; Layne 2012; Monteiro 2014; Waltz 1993; Zakaria 2011; Arrighi 1994, 2007). The thesis of unipolar pessimists is hardly new, for as 
Gilpin argued in the 1980s, while the normative role of a hegemon is to act as the cement binding the international system (providing collective private goods like security where no state can be denied access to a good or where consumption of a good by one actor does not preclude its enjoyment by others), the rapid expansion and financialization of the global economy under American leadership has unleashed centrifugal forces that will ultimately overwhelm the US. Anticipating Arrighi (1994), Gilpin (1987) stressed that corporations in a global capitalist economy must continually restructure and relocate economic activities to remain competitive and expand market share, with major implications for the geoeconomic balance of power: unleashing the global market, he argues, creates a 'new political environment [...] With the inevitable shift in the international distribution of economic and military power from the core to rising nations in the periphery and elsewhere, the capacity of the hegemon to maintain the system decreases' (Gilpin 1987: 77-8).

Unprecedented in the present epoch are: (i) the gap between US military and economic capabilities; (ii) the rapidity of America's decline from unipolar ascendency in the 'permissive environment' of the early post-Cold War period to defensive retrenchment and reluctant multilateralism in the present decade as the geopolitical foundations of the US-centric order are eroded; and (iii) the growing gulf between the wealth of transnational financial corporations headquartered in the US and the collapse of America's economy since 2007. Yet mainstream IR continues to be framed in terms acceptable to US foreign policymakers. The only issues separating neorealists and neoliberals are their respective views on the possibility of multilateral cooperation: both elide not only the precedents for America's intervention in Iraq (Sarai 2008; Burman 2007; Hartnet \& Stengrim 2006; Konings 2010; Stokes 2004), or the manipulation of the international monetary system by the Federal Reserve (Hudson 2003; Wheatley 2013a), but also the illiberal character of neoliberalism as an economic ideology which has destroyed embedded liberalism in favour of corporate ownership and privatized citizenship, leading to a general 'regression in thought and social organization that has been detrimental to the vast majority of individual lives and societies as a whole' (Bone 2010: 725; O’Flynn 2012; Wallerstein 1995).

Despite the deep malaise of US society (Hedges 2009; Berman 2011), as apologists for Western hegemony, neorealists and neoliberals both contend that the US must remain active in the field of global security by countering regional hegemons and binding rising powers within the existing structure of global governance. Yet the shifting nature of world order is reflected in a trend towards 'soft balancing' as proto-peers and regional powers seek to counter US leadership in global institutions without challenging the US directly (Pape 2005; Bobrow 2008). This has caught the Anglosphere by surprise, no less than Russia's willingness to use 'hard balancing' to limit the North Atlantic Treaty Organization's (NATO) encroachment into the post-Soviet space of Eurasia, which has led the US in turn to retaliate with economic sanctions and pressure on Saudi Arabia to depress the market price of Russia's primary export 
and source of hard currency. These developments presage the end of a distinct period in the evolution of the international system:

The post-Cold War era was quite literally defined by endings: of bipolarity, and of the threat of total nuclear annihilation. That ending has, at last, ended. Post-post-Cold War politics are defined by an increasingly chaotic diversity of ideas and practices. That the Chinese, Indian and Russian models of capitalism diverge systematically from the erstwhile simplicity of market fundamentalism is hardly surprising. The same holds in the security realm where these and other rising states seek their own roles, channels of influence, and representation in regional and global governance structures, which the old American-made Cold War and post-Cold War order by its very nature could not accommodate.

(Abdelal \& Krotz 2014: 132)

The US has attempted to impose a rehierarchization of world order, arrogating 'special governance rights' to Western economies while denying equivalent categorial rights to self-determination and non-intervention to emerging economies (Reus-Smit 2005b: 72). Yet the era when international relations could be guided and balanced by a 'superpower' is ending and those observers who still see 'no credible alternative to the American role as lynchpin and guarantor of the global system grossly overestimate the current US capacity' (Cohen 2008: 3; Layne 2012).

What remains to be determined is whether peaceful transition to multipolarity is possible - facilitating the ascent of China, India, Russia and Iran as emerging powers (Zakaria 2011; Hiro 2010; Tselichtchev 2012), or whether the US will attempt to delay global convergence by embroiling contenders in low-intensity regional conflicts (as in Ukraine) or fostering internal unrest (as in Iran). The power of the Anglosphere derives from the transnational organization of capitalist finance, which has accelerated the de-democratization and deterritorialization of political decision making, yet the uncontrolled growth of neoliberal globalization has also accelerated the rapid and uneven growth of capital markets and investment outside the Lockean heartland. The paradox of world order is that having created the institutional basis for multilateral trade and governance, the West is unwilling to sanction a minimum level of geopolitical rebalancing necessary to allow contenders a proportionate voice in international politics or to enable the global market to function as neoclassical theory claims it ought - that is, by yielding positive-sum welfare gains through free trade. This subversion of rationality by Western financial capital lies at the heart of recurring crises in the Western-led global economy which emerging economies blame on the 'domestic needs of the country issuing the primary reserve currency [clashing] with international fiscal requirements' (Hiro 2010: 287).

This leads to a third major theme in the text, namely the origins of America's economic decline and the problem of overaccumulation in financialized 
economies. Much has been written on the origins of the global financial crisis and the financialization of Western economies, and as we shall see in Chapter 5 , the decline of the US economy has been determined less by cyclical than structural economic factors - an historically specific confluence of contingent processes including weakness of demand formation (Cynamon 2013; Foster \& Magdoff 2009; Stiegler 2011), fiscal and monetary instability, misallocation of capital and mass employment (Nasser 2013), constraints to growth posed by declining access to cheap energy (Heinberg 2005; Ruppert 2004), and the reappropriation of developmental sovereignty by non-Western states acting through regional organizations as competitors to the Washington consensus (Nicolas 2012; Telò 2007; Ambrosio 2005; Chance 2010). However, the origins of the crisis lie in the nature of capital itself, and in the attempt by corporatestate elites to overcome the contradiction between accumulation and declining profitability in deindustrialized societies.

In liberal economic theory, overaccumulation is typically defined as capital superabundance, a self-generating process stimulated by financial innovation and securitization, through which investors leverage positions and maximize yields at the expense of long-term investments. In critical IPE, on the other hand, overaccumulation is linked to a decline in the rate of return on capital investment and the failure of the rate of profit to recover from recessions, leading to a structural crisis of valorization where financial and nonfinancial corporations seek higher returns through the accumulation of 'fictitious value'. Defined in orthodox or Marxian terms, however, the assumption is the same: that the value of 'fictitious capital' has expanded so far out of proportion to the 'real' economy of production and consumption that the latter risks being overwhelmed by a glut of idle capital that cannot be usefully or profitably invested. The beneficiaries of this system are assumed to be predatory (and interchangeable) corporate-state elites that have depended on fiat money creation to sustain their power over local economies based on consumption and savings for the last four decades.

However, while it is accepted that revenues generated through financialized capitalism dwarf the level of value generated in commodity production, and while devaluation and deleveraging are sources of instability in financialized economies, the argument that capital accumulation has reached its historic limits must be placed in question, not merely because new potential sources of value augmentation exist beyond the US, EU and Japan, but because the assumption that value is derived exclusively from direct exploitation of labour-power as a commodity is unsustainable. As we shall see in more detail in Chapter 2, capital constitutes an abstract ordering force which anticipates new forms of spatial organization to sustain the subsumption of new geographical regions, populations and resources beneath the category of value.

Yet we cannot proceed with an analysis of dominant capital unless we are prepared (i) to rethink the classical Marxian notion of value as a precise 'crystallization' of abstract labour, and (ii) to question the false dichotomization of real and fictitious value in historical materialism. In recent years, 
energetic attempts have been made to save Marx's labour theory of value from revisionist critique by focusing on its purely symbolic function as a critical discourse on capital enabling individuals to comprehend the hidden nature of capitalist exploitation (Harvey 1982; Hardt \& Negri 1994). However, attempts to disconnect the quantitative and qualitative dimensions of the labour theory of value are extremely problematic, for, as Nitzan and Bichler (2009: 124) argue, studying the 'rationalist order of capitalism without quantities is like studying feudalism without religion, or physics without mathematics'. By definition, the authors observe, capital 'seeks to turn quality into quantity, to objectify and reify social relations as if they were natural and unassailable' (ibid.). Marxian IPE should be concerned less with the production of value through material exploitation of human labour-power than the architecture of global financial capital as a transnational mode of power realized through the organization and manipulation of markets and prices by financialized corporations.

Commodity production remains central to the generation of value in all capitalist formations, yet continuous realization of above-average profit by financialized corporations has less to do with transforming units of abstract labour into surplus-value and more to do with capitalization, namely the capacity of investment managers to speculate on financial outcomes and estimate the precise quantity of money capital to invest in the present in order to realize future gains, a practice that has accelerated as a consequence of the continual innovation of new financial instruments. That is to say, the scale and scope of capitalization have increased through the continual creation of more complex financial instruments to leverage value from investments in equities and securities at higher rates than is possible through the exploitation of labour-power in simple commodity-producing societies or long-term investments in infrastructure and manufacturing industries.

As Mann argues in his critique of McNally (2009), the crisis has consolidated rather than destroyed the 'rule of value', for the economic reality of the crisis "lies not in the destruction of value, the end of "fictitious" capitals and "artificial" assets, but in the movement (or otherwise) of the category of value itself to higher levels of abstraction and opacity' (Mann 2010: 174). The power of capital

lies to a significant extent in the expropriation of labour's surplus product, but the exercise of that power resides more fundamentally in the hegemonic-categorial logic of value: the territorial and historical imperative of equivalence and substitutability. Abstract labour remains a crucial manifestation of this relation, but our current condition demonstrates that value itself is not beholden to labour. The present hegemony of the category of value is buttressed by capital's own accumulatory dynamic, but also by larger transformations in the way that the state exercises its capacity to govern. These include changing ideas of how the state in capitalism should exercise authority and those particular shifts in 
regulatory arrangements that liberate capital, via accelerated financialization, from a dependence on labour's productive capacity, without hindering its mandate for self-expansion.

(Mann 2010: 177-78)

Financialization is usually explained as an intensive mode of value augmentation and self-synthesis characterized by overaccumulation - the production of excess capital in proportion to opportunities for its profitable use where 'individual capitalists driven by competition and striving to maximize their profits through the exploitation of labour power adopt technologies which drive the economy away from a balanced accumulation path' (Harvey 1982: 308). On this view, capital is gradually withdrawn from productive circulation and immobilized in the money form as corporate actors diversify away from productive to speculative investments yielding above-normal returns from market trades in derivatives and other securitized assets unconnected to their core business. Yet it is difficult to distinguish categorially between 'real' and 'fictitious' value, for as Mann (2010: 180) notes, the 'astounding power of the category of value in capitalism lies precisely in the fact that it "really" renders these distinctions meaningless'. What defines capitalist value are the equivalence and substitutability that erase qualitative distinctions between exchangeable commodities: 'Surely,' queries Mann, a 'theory of value that relegates a substantial part of value in circulation to the realm of the fictitious can do little but distract our attention from the fact that the capitalist dynamics which fundamentally determine our lives depend not on artificial variations of value but on value per se?' (ibid.: 181).

Securitized asset values are simply paper claims to future value, and to fetishize the category of real value over its fictitious form is to fall into the trap of reformism which seeks to salvage and relegitimize the productive accumulation of value in state-democratic formations as a benign mode of economic reproduction immune from the pathologies of 'financial gambling' (Mann 2010: 179). Hypothecated values do not negate the pecuniary reality of synthetic paper investments as derivative forms of money capital in financialized economies. What is clear, however, is the discrepancy between the weak financial power of emerging markets and the concentration of capital in G7 financial centres that export inflation and low growth via monetary expansion and financial statecraft to developing societies - treating emerging market economies as 'disposable adjustment mechanisms' (Raghuram Rajan, cited in McKillop 2014).

This reflects the comparative advantage enjoyed by the West of a stable 'trust architecture', namely 'property rights protections, reliable legal systems and institutional depth that owners of capital value' (Bain \& Company 2012: 15). Yet despite this comparative advantage, the West is locked into a spiral of decline as corporate-state elites jettison the growth paradigm of the 1950s for a post-growth economy - a 'socialism for the 1 per cent' where the corporate interests of system-relevant financial institutions prevail over an efficient 
allocation of resources (Luce 2014). This has increased rather than diminished the role of the state in the political economy of corporate power and, as McKillop (2014) argues, the larger the revenue obtained through this rentier system the more elites can ignore the economic performance of any activity. Although supported by a sophisticated national security state (Marshall 2010; Pease 2010), this 'economy' is unsustainable because oligarchy 'seals its own demise by and through dependence on the rent-takers and seekers who are inevitably corrupt' (McKillop 2014), flouting economic rationality and the fiscal stability of states through a restriction of competition and transferral of private corporate debt to taxpayers (cf. Lynn 2010).

\section{The political economy of world order}

At the end of the millennium realists hypothesized three models of world order in the twenty-first century: 'geoeconomic realism' - the assertion that military conflict is giving way to non-violent economic rivalry between states; multipolarity - the view that America's 'unipolar moment' is likely to be shortlived, leading to conflict between the hegemon and revisionist contenders; and a US-centric order where the US refuses to retrench and unipolarity prevails (Mastanduno 1999).

Liberals, on the other hand, have been more concerned with the juridification of international relations and the increasing interdependence between states in a globally integrated economy: however paradoxical, 'the measure of a state's capacity to act as an independent unit within the international system - the condition that "sovereignty" purports both to grant and describe - depends on the breadth and depth of its links to other states' (Slaughter 2005: 63; cf. Chayes \& Chayes 1995; Boyle 2010). Liberals of all schools insist that the world is entering a period of greater transnational institutional innovation and constitutional pluralism in which exclusive sovereignty - a 'political entity's externally recognized right to exercise final authority over its own affairs' (Biersteker \& Weber 1996) - is made redundant by interdependence, where states continue to pursue self-interested cooperation but no longer exercise or claim exclusive prerogative right in the conduct of interstate relations (Keohane 2002; Teubner 1997; Rosenau 2007; Gallarotti 2010). Liberals concede that only national states can claim the "political imprimatur that is bestowed by political accountability' (Slaughter 2005: 35), yet welcome the transition towards disaggregated sovereignty and the diffusion of power in supranational institutions (Guzzini 2012). From a liberal-institutionalist perspective, international order is no longer contingent on 'separation, autonomy, and defined territorial or jurisdictional boundaries, but rather entails connection, interaction, and interpenetrating networks and institutions [...] "Sovereignty as autonomy" makes no sense today' (Slaughter 2004: 7; cf. Willke \& Willke 2012: 74; Bjola \& Kornprobst 2011).

This is complicated by a parallel debate within Marxist IR on the political economy of world order, where discussion centres on the geopolitical and 
sociomaterial conditions of 'empire'. On one side of this debate sit 'traditional' Marxists, who link globalization in a conventional sense to imperialism - an economic system based on the subordination of international political economy to the 'forms of accumulation in the core capitalist states of the world market' (Hanieh 2013: 46; cf. Poulantzas 1975; Petras \& Veltmeyer 2001; Berberoglu 2005; Harvey 2003; Callinicos 2009; Panitch \& Gindin 2004; Bromley 2003). Here the explicit assumption is that US global hegemony after 1945 led to a restructuring of the advanced economies in the 'capitalist chain' in the interests of multinational corporations headquartered in the US and owned primarily by US investors. On the other side of the debate, neo-Gramscian scholars have focused on the conditions of reproducibility of US international hegemony (Cox 1983; Arrighi 1994), rejecting the explanatory emphasis of neorealist scholars who emphasize the cyclical mechanisms of economic change that determine the secular rise and decline of sectors of production and changing patterns of investment in new sectors of economic activity in the evolving hierarchy of capitalist economies. For Gramscians, the rise and fall of empire is linked to financialization and the declining capacity of the hegemon to sustain the material and ideological conditions for military preponderance.

Wallerstein offers a highly sophisticated version of neo-Marxism based on his reconceptualization of Kondratieff long-wave cycles in history. He argues that the capitalist world system that emerged in the sixteenth century has now reached an impasse as a result of the declining profitability of capitalist forms: over coming decades, he predicts, the world system will be characterized by conflict between those committed to sustaining the system (transnational investors and their political allies) and those groups seeking a just alternative (the rest of humanity). On this view, the world system maintains itself via 'mechanisms that restore equilibrium every time its processes move away from it. The equilibrium is never restored immediately, but only after a sufficient deviation from the norm occurs, and of course, it is never restored perfectly' (Wallerstein 2006a: 75). One of these mechanisms is the state form of capital, defined as the 'facilitator of the value-form determined processes of valorisation and accumulation, and reproducer of the right to levels and forms of usevalue consumption adequate to realise the right to existence' (Reuten \& Williams 1989: 264), which stabilizes markets by socializing losses to mitigate the destabilizing effects of financialization. Systemic crises are becoming increasingly serious, but while neoliberals depict the crisis of 2007-09 as a 'normal accident' - the 'temporary breakdown of a high-risk system' that can be managed (if not fully resolved) through governance reforms under Western leadership (Willke \& Willke 2012) - neo-Marxists insist that disruptions of this magnitude are likely to trigger irreversible change in the structural parameters of the world system, exposing the limited range of options available to corporate-state elites acting transnationally (Angeloni 2012). As Wallerstein notes, secular trends 'cannot go on forever because they are hot asymptotes' (leading to diminishing returns as cyclical patterns reach their upper limits). 
As systems approach their asymptotic limits, it is more difficult to reproduce conditions of equilibrium. As a result the system approaches terminal crisis and 'bifurcates - that is, finds itself before two (or more) alternative routes to a new structure, with a new equilibrium, new cyclical rhythms and new secular trends' (Wallerstein 2006b: 75).

Thus while liberals view capitalism as a global force 'sustained within a network of economic financial, technological and regulatory interdependencies' necessary to compensate for systemic risk (Willke \& Willke 2012), critical international theorists focus on the material logic of corporate power in the global economy, emphasizing the limits of globalization and the potential for counterhegemonic struggles (Worth 2009; Bedirhanoğlu 2008; Cutler 2005; Robinson 2006). However, while critical theory is right to identity the illiberal face of corporate globalization and its dependence on coercive force to remove barriers to capital - rejecting liberal normative justifications which state that globalization displaces premodern normative hierarchies with polyarchy and secularism (Willke 2009) - the epistemological substance of their critique is tied to a nineteenth-century model of economic development based on historical materialism. Neo-Marxists are effectively tied to a theory of historical capitalism, failing to notice that the authentic object of Marx's historical science is not history but capital: 'The epistemological warrant for Marx's procedure of inquiry', argues Westra, 'derives from the ontological peculiarity of the object: the tendency of capital towards self-abstraction and self-synthesis, enabling theory to trace the unfolding of all the categories of capital in a dialectical thought experiment' (Westra 2010: $61)$.

In a global capitalist order defined by disaggregated sovereignty, in which territorial state power is reframed through cross-cutting vertical/horizontal institutions of global governance linking state and non-state actors, the transnational organization of global capital is no longer coterminous with the 'sovereign' interests of nation-states, as realists argue, or national capitals, as Marxists claim. Rather than assume that national interests are derived exclusively from the priority of survival in an anarchic international system, national interests should be seen as 'political constructs serving a particular social purpose' (Apeldoorn 2014: 16). That social purpose is the valorization of value, and in a posthegemonic capitalist order no single state can act as the indispensable lynchpin of the global economy (Robinson 2004b). While it is useful to examine the state-specific coherence of capital accumulation and while states show preference to corporations that advance their own geopolitical interests, it is necessary to move away from state-centric approaches to globalization and imperialism towards a conception of world order based on open regions because the national/international distinction is no longer an 'immutable structural feature' of world politics (Robinson 2004a). From this perspective, to describe the international system in the traditional language of 'imperialism' is simplistic because US corporations are 'no longer subservient to any imperial centre or purpose but multiply their private money sequences 
on the back of monopolies of force and money-issue paid for by increasingly impoverished citizens' (McMurtry 2014: 8). It is perhaps more accurate to argue, as Wilson observes, that the extent to which international relations is "subordinated to the paradigm of "securitization" and the technocratic computations of anticipatory self-defense, true politics becomes the exclusive domain of parapolitical entities who are continuously deciding the emergency within an eternal (and historically suspended) present' (Wilson 2012: 27).

In the global capitalist economy, finance is the dominant form of capital and if globalization were nothing more than a cipher for American imperialism, as Panitch and Gindin believe, then 'finance capital would have to be dominated by US institutions', which is not the case, for only 20 per cent of the 495 leading global corporations classified as 'banking and diversified financials' are from the US (Fuchs 2010: 239). The political economy of world order is based less on the prerogative right of the US as a hegemon acting as the executor of Western imperial interests, than on the shift from a US-centred economy to a decentred global corporate system increasingly organized around growth poles in emerging market economies where the global financial crisis is viewed more accurately as a crisis of the Western financial system. The expansion of capitalism in the present epoch reflects the globalizing logic of corporate capital rather than imperial power, such that the 'universality of capitalism - its social relations, rules of movement and contradictions - and the logics of commodity economy, capital accumulation and pursuit of maximum profit have permeated each and every corner of our lives' (Daping 2012: 23). Although US military power is deployed for the destruction of regional and local sovereignties, the radical 'decentring' of world order is determined in an objective economic sense by movements of capital that are beyond the capacity of any state to organize or control. As globalization exceeds the geopolitical logic of liberal internationalism we are witnessing an authoritarian intensification of valorization necessary to structure the global totality through the continual expansion of the value form across globalized and regionalized circuits of power (Liodakis 2010).

\section{After hegemony}

Traditionally understood, hegemony indicates the existence of a single state with the capacity to impose a stable hierarchical organization in the distribution of power which other states support in their own interests, implying an absence of military struggle between states and extended periods of accumulation. The concept has been qualified by neo-Gramscians such as Cox, who argues that hegemony is founded 'not only upon the regulation of interstate conflict but also upon a globally conceived civil society, i.e. a mode of production of global extent which brings about links among social classes of the countries encompassed by it' (Cox 1996: 136). It has also been criticized by Gill, who notes that traditional geopolitical definitions are limited since they link 'social forces with a territorial entity, whereas the global system needs to 
be conceived as a totality, and the social forces that operate within that system are not territorially bounded or determined' (Gill 2008: 36).

The question for critical theory, however, is not whether unipolarity is conducive to global security by providing incentives for strategic restraint, as Ikenberry (2001) and others once argued - overlooking the point that states with an 'elevated position to maintain' possess a 'heightened and exaggerated perception of the importance of threats in a global context, and a tendency to pacify or police "turbulent boundaries" (Jervis 2011: 266; cf. Monteiro 2014) - but whether the notion of 'imperial prerogative' remains a meaningful notion in a posthegemonic world order. As Russia's opposition to US unilateralism has shown, history always returns to remind us of the plurality of the world, and revisionist states will continue to matter in the twenty-first century and will continue to defend their interests by force if necessary. However, while states facilitate the political organization of capital in capitalist societies (including Russia and China whose own elites are adaptive to the opportunities afforded by global capitalism), the dynamic subject of capitalism is not a political force as such: the new nomos of the earth is no longer consistent with the interests of the leading state in the imperialist chain, as Poulantzas (1975) argued, nor does it enact a self-regulating legal balance between competing equal sovereignties, as Schmitt (1950) argued. Rather it reflects the power of capital to incorporate the political in a transnationally constituted structure of private economic power.

Neo-Marxist theories of global capitalism as an historical social system move beyond the confines of realist geopolitics as the spatial organization of human activity. In contrast with Kindleberger (1973), Modelski (1987) and Ikenberry (2008), Marxists stress the economic logic of capitalist forms expressed in cycles of accumulation and financialization in which capital is diverted from trade and production towards more risky investments. An aspiring hegemon creates new frameworks of control at particular stages in its evolution, and must resolve contradictions in the world system or lose supremacy to a competitor better positioned to take advantage of new economic and technological conditions forged under the "carapace of imperial organization' (Arrighi et al. 1999: 37). The US is in decline, argues Arrighi (2007), because it is fixed on a 'path-dependent' course of financialization that it is powerless to change, and it is only a matter of time before the baton of hegemony is passed (peacefully or otherwise) to China as the latter gains ascendancy as the major growth pole in the global economy.

Yet it is unclear whether and to what extent the historical-sociological model identified by Wallerstein or Arrighi fits with the present world system, for while it is instructive to theorize patterns of hegemonic transition, capitalist sovereignty suggests something broader and more diffuse than state hegemony. In addition, there are too few historical cases of hegemonic transition from which to draw positive law-like hypotheses linking the development of capitalist cycles to empire, and predictions of Chinese hegemony in the twenty-first century must be tempered by the fact that the term 
'superpower' is an historically contingent phenomenon reflecting the huge asymmetries of power between the West and the non-Western world during the Cold War. While comparative analyses of historical financializations under the Dutch or the British are instructive, there is no real precedent for the unique conditions that facilitated the spectacular rise of the US after 1945, in particular the role of the US dollar as a global reserve currency, the weakness of competing economies destroyed by US air power during the Second World War, the existence of a common ideological enemy to sustain the transatlantic alliance, and the availability of abundant cheap energy to sustain the permanent warfare state.

More seriously, however, the premises of generic theories of financialization, which see it as a 'deviation' from the normal course of productive capitalism, are highly questionable. While financialization is linked to overaccumulation, characterized by the non-reinvestment of profits in directly productive processes, the tendency of historical sociology to rely on the idea of 'deviant finance' suggests a theoretical blind spot - one that is responsible for the sterile distinction between manufacturing and non-material economic activity. As Marazzi argues, the 'abnormal development' of finance in the global economy of production and consumption may be alarming, but vague notions of reindustrialization are characterized by a lack of realism (Marazzi 2010: 48-9). The violence of financial capitalism may distort local economies and undermine stability, but it is linked to new processes of value production which are increasingly opaque; and, while it is common for writers on the Left to celebrate the class compromise of Fordism, it is futile to glorify 'golden era' capitalism in a global accumulation regime dependent as much on complex financial instruments as production of tangible commodities with use value. In contrast with simple commodity capitalism, value is no longer captured wholly or directly through production (where deriving value from labour-power is increasingly problematic), but through apparatuses for capturing value outside directly productive processes in the sphere of circulation and exchange (ibid.: 55).

Financialization further indicates the specific historic function of biocapitalism, namely the production of value by extracting it not only from the body functioning as the material instrument of work, but also from the body understood in its globality' (Marazzi 2010: 50). Using a transhistorical approach, defining capitalism 'with reference to the state becomes a conceptual straitjacket when [Arrighi] attempts to analyse the contemporary world' (Postone 2007: 15). In addition, his conceptualization of capital lacks specificity as he links the rise and fall of successive capitalist episodes to the actions of hegemonic powers rather than attempt to explain the material logic of capitalist sovereignty in the present period. Rather than dovetail geopolitics and world history, 'the large-scale historical pattern that structured much of the twentieth century suggests the existence of overarching structural imperatives and constraints that cannot adequately be explained in local and contingent terms' (ibid.: 8). 
Critics like Agnew argue that globalization correlates with the economic/ cultural power of the US as a business civilization that posited itself as a universal telos for mankind, and with a 'quickening and geographical reformulation of the progressive universalization of capitalist commodification and accumulation' (Agnew 2005: 2; cf. Boggs 2011a). Yet his additional claim - that globalization is a 'hegemonic project intimately connected to the geopolitical calculus of the US government and economic interests' (ibid.) raises more questions than it solves, because not only does it assume America planned globalization, but that the future of the international system is dependent on US leadership. In fact, Agnew's argument is better expressed in reverse, for the financial and military power of the US in the international system is no longer the determining factor of globalization but the other way around: globalization follows the logic of a corporate business culture that emerged in the US in the nineteenth century, and which required US leadership to arrive at its present state, but this model of economic growth is no longer unique and is no longer organized in the exclusive interests of the US as the 'indispensable' nation because the direction of transnational corporate investment has long been detached from the interests of America as a society.

Financialization has not worked for the US, and 'despite the alleged omnipotence of its Wall Street-Washington Complex, despite its control over key international organizations [...] the bottom line is that the net profit share of US-listed corporations has kept falling' (Nitzan \& Bichler 2012: 60). Confronted by weak domestic growth, US financial capital prioritized its external economy, adapting to changing patterns of trade as emerging markets attracted greater shares of FDI. The changing geoeconomic balance of power is indicated by the sharp decline of America's share of global output, which on a purchasing power parity basis has fallen below 20 per cent (Davidson 2014). Statistics published by the World Bank show that the contribution of developing economies to global trade flows rose from 26 per cent to 42 per cent between 1995 and 2010, due to increasing trade between emerging markets. By 2025, the study concludes, growth

will predominantly be generated in emerging economies. Although many high-income countries are only gradually recovering from the financial crisis, most developing economies have swiftly returned to their fast precrisis growth trend [... S]ix major emerging economies - Brazil, China, India, Indonesia, the Republic of Korea and the Russian Federation will collectively account for more than half of all global growth.

(World Bank 2011: 2-3) ${ }^{2}$

While higher added value has historically been generated in the advanced industrialized economies (Scott 1997; Phelps 2008; Henderson et al. 2002), preserving the comparative technological advantage of the West, all sovereign territorial units are now measured equally on their relative merits by investors as spaces for accumulation, to be integrated into or detached from global 
value chains in pursuit of higher levels of profitability (Milberg \& Winkler 2013; Wallace \& Brady 2010). Furthermore, while US hegemony has been an embedded feature of corporate globalization, establishing relations of production typical of US capital in both core and peripheral economies (Poulantzas 1975), transnational corporate power is no longer coterminous with the economic interests of the US itself. More than 70 per cent of the American economy is based on consumption while internal investment constitutes only 12 per cent of gross domestic product (GDP) - not because there is little to invest in but because US corporations keep profits offshore and direct their investment towards offshore markets which do not benefit the US (Rickards 2011; Standing 2007; Deneault 2010). The gains of offshoring have not been realized in America because it has handed production to foreign subsidiaries, and 'despite the corporate sector's contribution to national savings over the past decade, the offshoring-financialization linkage creates a structural limit on the capacity of non-financial corporations to act as engines of growth and innovation' (Milberg \& Winkler 2013: 211). To explain this contradiction, we have no option but to decouple the transnational power of capital from the future of the US as an 'imperial' nation.

The tendency to define geopolitics in the language of empire is hardly restricted to neo-Marxism. For Schmitt (1950), the historical evolution of world order is always determined by successive secularized theologies of power which derive their force and meaning from the political rationality of a proto-hegemon, which he located (after 1945) in the unrestricted extension of US sovereign power beyond the logic of its geographical territorialization (Ortung). The imperial narrative of American militarism is not difficult to find, for in the US geopolitical imaginary the earth is divided in a 'cartography of separation' between zones of civilized peace and zones of unavoidable conflict which compel the US to adopt a 'warrior ethos' to manage the ebb and flow of violence and pacify the 'remote periphery' (Lipschutz 2009; Kaplan 2002). Although the ideology of benign intervention prevents the US from understanding that its prior actions may have caused the problem 'to which subsequent "interventions" are deemed the appropriate policy response' (Dalby 2013: 38-9), in Schmittian terms it assumes the form of the katechon - that is, the mythic image of imperial authority which 'keeps chaos at bay' (Vaughan-Williams 2011).

Yet, far from standing above the 'ebb and flow' of a rising tide of political violence, this mythic figure stands on closer inspection for the power of a sovereign who strives to withhold and delay a necessary transition in world order - a declining hegemon with its eyes fixed on the ruins of empire that lie before it (Hell 2009). This has led the US to normalize a state of exception (Agamben 2005), engulfing the West in a potentially unending 'global war on terror' to sustain a transnationally constituted system of monetary power threatened by global economic convergence and the evolution of counterhegemonic regionalism. Unable to relinquish its 'geopolitical imaginary', the US remains confined in the fantasy of its 'unipolar moment', seeking to delay 
its inevitable ruin by conflating the universalizing global imperative of capital with the particular interests of the West. Confronted by the spectre of global economic convergence instantiated by the internationalization of capitalist social relations, the US is emerging as a geopolitical barrier to 'reasonable change' in a paradoxical attempt to forestall the overdue end time of empire (Hell 2009). It thus finds itself in a dialectically contradictory position, on the one hand acting as a katechon to delay the inevitable course of history (Verzöger der Weltgeschichte), and on the other acting as an 'accelerator [of world history] despite itself' (Beschleuniger wider Willen) (ibid.).

To explain neoliberal global capitalism as an historically specific form of social life, therefore, we must explain capitalist sovereignty as a transnationally constituted mode of power that transcends national politics but which orders political and cultural forms through the corporate reorganization of advanced and peripheral economies. This reflects the unidimensional rationality of a 'business civilization' (Laski 1936), and the unrestricted economic logic of corporate power as the social embodiment of the law of value which operates with 'ever more force vis-à-vis the states and national economies subsumed under this law' (Smith 2003: 30).

In the new global economy territorial states are being transformed into administrative instruments for restructuring spatial units in response to investment priorities of transnational corporations: corporatism constitutes an objective form of domination based on the differential capacity of dominant capital to gain access to and control markets, to restrict competition and to steer the political decision making of national economies. As the twilight of the Euro-Atlantic age nears, however, there is increasing tension between the plurality and spatiality of capitalism and the imperial self-identity of the West which is unsustainable in a world dominated by the rising power of Asia (cf. Mahbubani 2013). The decline of the West is not simply a result of its ageing population (Sönmezler et al. 2010), but of wage disparities between the Organisation for Economic Co-operation and Development (OECD) and emerging market economies, declining intellectual and physical capital, low investment, rising energy costs and the corruption of democracy by corporate oligarchy (Winters 2011). This is leading to global restructuring as financial capital flees stagnant geographic regions and corporations seek profitable investment in growth poles beyond OECD states. Only if globalization is understood in its totality - as a transition from imperial state authority to transnational corporate power based on the spatialization of labour processes where 'work tasks can be done in different locations with no loss in profitability or control' (Wallace \& Brady 2010: 133) - is it possible to understand capital as the objective subject of modernity. Globalization has altered the connection between territoriality and power, and the global financial crisis has created the momentum for a further transfer of decision making to institutions of global governance.

Corporate power is the political-organizational logic that drives global capital, and the intensification of corporate political and ideological power ultimately 
derives from its capacity to develop a legitimizing rationality comparable in force to that of the medieval Church or the absolutist state. The corporation has evolved as the prevailing form of human social organization for two main reasons: 'First, there was a shift in institutional and organizational structure of lead polities, and second, there was a shift in the relative importance of the groups [...] that held power and produced rationalities, away from political elites and toward corporate elites' (Harrod 2006: 29).

As we shall see in Chapter 3, it is easier for transnational elites to internationalize this legitimizing rationality through globalization than it is for individual states to internationalize the legitimizing rationality of specific political cultures, even as oligopoly undermines the integrity and efficiency of 'free' markets as means for allocating resources (Harrod 2006: 45). As we shall see in Chapter 4, class formation is determined to a greater extent at a transnational level through formal (public) and informal (public/private) networks that insulate absentee corporate actors from the territorial complexity of business operations (Robinson \& Harris 2000; Carroll \& Carson 2006; Carroll 2010; Everling 2010), though such networks are too diffuse to create a unified global class in the orthodox Marxist sense. Lacking class consciousness as such, transnational capitalist elites represent a personification of economic categories of financial capital whose power is reflected in their mobility, their insertion within global and regional networks of power, and their capacity to leverage the mobility and power of finance to consolidate their domestic bargaining power within national polities (Talani 2012: 160). The rise of a transnational capitalist elite forces us to abandon hierarchical conceptions of order based on interstate rivalry where "the (national) state is the point of backward linkage to society and forward linkage to the international order' (Robinson 2006: 168). Instead, we must understand how 'capitalists and allied dominant strata integrate horizontally and in the process move "up" cross-nationally, penetrating and utilising numerous national and transnational state apparatuses to forge their rule' (ibid.).

To understand global corporatism, therefore, it is important to note that capital is power. Carroll identifies three forms of economic power based on control over capital: the operational power of corporate management over the labour process; the strategic control of investment decisions based on majority holdings of interlocking corporate institutional shareholders; and the allocative power derived from control over credit (Carroll 2004: 5; Scott 1997). Following Veblen (1923), Nitzan and Bichler assess the differential power of dominant capital, whose capacity to marshal resources and control human activity through the organization of markets suggests a parallel with Mumford's (1967) model of the 'social machine', the goal of which is to structure the totality through the imposition of labour on society. Accumulation, they suggest, represents the capacity of dominant capital to accumulate faster than the average (Nitzan \& Bichler 2009: 17-18).

On this basis, it is necessary to differentiate business (corporate rivalry) from industry (the creative productivity of society), and the tendency of big 
business to exploit preferential access to financial capital to acquire and/or asset-strip profitable concerns (cf. Froud et al. 2006). Corporations maximize neither competition nor productivity; rather, they seek to limit competition and productivity through asymmetric market power. Dominant capital subverts competition, exposing the liberal myth of ordered risk taking in preference for rent seeking. At stake here is the utility of the idea that competitive risk taking carries a positive value, suggesting the extinction of a moral-political order founded on entrepreneurship as competition becomes less relevant to pricing decisions and as prices reflect not value but market power - that is, the capacity of dominant capital to control the productivity of society for its own pecuniary gain (Picciotto 2011: 108-16), exploiting asymmetries within and between states. Capital thus becomes accumulated power, while politics (as Dewey observed) is the 'shadow cast by big business on society'. In this sense, the differential power of dominant (global) capital is the underlying condition for predatory globalization: accumulation through oligopoly, enhancing the control of transnational investors over markets while limiting the capacity of local communities to resist the privations of corporate power.

\section{Conclusion}

In contrast with the late nineteenth century, when the world economy was governed by clearly demarcated territorial empires, in the new global order states remain 'ontological givens', though global economic integration is increasingly determined by transnational corporations acting through state, regional and transnational structures of power to sustain and expand opportunities for differential accumulation. As Van der Pijl (2001) argues, the present capitalist system is characterized by a combination of the discipline of capital' and the interests of elites in powerful states, sustained by the expansion of consumerism and debt, creating an ecologically destructive system which threatens the integrity of human life. Since the 1980s global capitalism has been reorganized spatially within and between regional blocs in accordance with the security, investment and trade priorities of transnational corporations rather than free trade or liberal cosmopolitanism, which not only raises issues of democratic accountability, but places in question the liberal ideal of a 'global civil society'. In the absence of formally democratic institutions of transnational governance, corporate actors combine with state and interstate actors to facilitate the valorization of capital in globalized and regionalized circuits of power at the expense of long-term investment in their own economies. On the one hand, the directionless logic of transnational finance indicates a trend towards nihilism, collapsing distinctions between culture, law and territory; on the other hand, globalization raises the spectre of neo-medievalism, which Bull (1977) juxtaposed to the 'universal competence' of legal-rational authority, subjecting states to centrifugal pressures while fuelling the growth of supranational regimes that constitute the state form of global capital (Friedrichs 2004). 
Marx stressed the tendency of capital to 'purge or purify its environment of non-economic, non-capitalist encumbrances', although it was already clear by the 1890s that capitalism 'no longer embodied the asymptotic tendency of capital to gravitate towards pure capitalism but rather entailed the maintenance of extra-capitalist excrescences' (Westra 2010: 18, emphasis added). This much, observes Callinicos (2005), is accepted by most serious students of international political economy, and it is inconceivable that financialized capitalism - particularly after the global crisis - could function without the intervention of state, regional and transnational authorities to mediate the growing power of corporate capital. In this global order states are themselves being financialized, as the intensification of derivatives trading forces governments to augment traditional forms of public finance by investing national assets in financial markets via sovereign wealth funds, which 'realign the value component of those asymmetries across global production networks by providing a disadvantaged country with some ownership over the advantaged country's domestic assets and the profits that arise', and which defend national sovereignty, 'protecting fragile political mandates while also limiting external interference' (Dixon \& Monk 2010: 11-12). Yet, while capital recognizes multiple jurisdictions, it falls under none; and while great powers may attempt to subsume the directionless logic of capital to the territorial logic of the state, the differential power of transnational capital over national capitals is an inescapable feature of the international economy in the transition from imperial state hegemony to global corporate power.

\section{Notes}

1 Writing before the dramatic yet ultimately retrogressive events of the 'Arab Spring', Simpfendorfer (2011) suggests that states such as Syria and Egypt were heading towards a period of sustained economic growth in partnership with China, opening up a new 'Silk Road' in Eurasia. Although this project has been undermined by conflicts in Mesopotamia and North Africa - fuelled by the external interference of Western and Sunni Arab states - the eventual re-emergence of a new Silk Road connecting China and Russia to Europe and the Middle East is seen by many observers as an inevitable development with major geopolitical implications for the West.

2 In April 2014, the World Bank estimated that China's economy would overtake the US for the first time (measured in terms of purchasing power parity) (see Giles 2014). The World Bank also estimated that the six largest middle-income economies - China, India, Russia, Brazil, Indonesia and Mexico - now account for 32.3 per cent of global GDP, while the six largest high-income economies - the US, Japan, Germany, France, United Kingdom and Italy - account for 32.9 per cent. 


\section{Capitalist sovereignty}

\section{Introduction}

To make sense of neoliberal global capitalism in the interstate system, it is necessary to examine the contradictory relation between capital as a selfvalorizing value prone to crises of overaccumulation, and the multilevel regulatory and disciplinary structures that transcend territorial states yet simultaneously articulate/augment the particular interests of the West - a hegemonic transnational entity that achieved unrivalled global power in the interimperial wars of the twentieth century. The notion of 'capitalist sovereignty' seems to imply the decline of the nation-state, yet the enduring presence of the state in capitalist society suggests that capital is dependent on its state form to reproduce the conditions necessary for the production of value.

The modern state evolved as a solution to the ontological contradiction between: (i) the universal and the particular, to allow for plurality and diversity within a universal state system; (ii) space and time, to organize and contain time within domesticated spatial contexts; and (iii) the self and other the need to distinguish friends and enemies based on a spatial demarcation of identities (Walker 1993). ${ }^{1}$ From a Marxian perspective, on the other hand, the state is also understood as an epiphenomenal expression of bourgeois class power - although Marxists recognize that all historical formations leave an enduring imprint on future societies and that the territorial unit remains a vital instrument of social control.

Although the geopolitical logic of accumulation in the age of absolutism (acquisition of territory to enhance the prestige of aristocratic/religious elites) is distinct from accumulation in a global economy - where transnational capital is relatively independent of the territorial logic of state power - as Callinicos (2007) argues, the global capitalist system is nevertheless determined by a dialectical interaction between capitalist and territorial logics of power. For this reason there is necessarily a 'realist moment in any Marxist analysis of international relations [...] such analysis must take into account the strategies, calculations and interactions of rival political elites in the state system' (ibid.). Yet contemporary geopolitics is determined less by pursuit of 
power for its own sake than by the specific form of intercapitalist competition in the world system (Pozo-Martin 2007) - that is, by the competition between capitals whose capacity to dominate markets is positively or negatively affected by their alignment and relative proximity to the nexus of financial and military power controlled by states. Geopolitics is not a 'means to its own end', a 'pure power politics aimed at power for power's sake [because] in geopolitical actions and concerns there always have prevailed mostly economic interests' (Adamo 2001: 490).

What, therefore, does it mean to speak of 'capitalist sovereignty'? As we saw in Chapter 1, this issue is inextricably tied to the core problematic of globalization, namely the transition from imperial state hegemony to global corporatism in a posthegemonic order where sovereign power is diffused through new structures of global capitalist integration and control necessitated by the transnationalization of production, trade and investment. Although this economic order has its political origins in colonial relations of domination established by Europe, the logic of corporate globalization lies not in empire building but in the diffuse articulation of capitalist sovereignty through a pluralistic structure of global governance which attempts to transcend the Hobbesian antinomy of disorder and sovereignty through the logic of synarchy, and thus to escape the 'classical categories of political authority, resting instead on the dialectical fusion of segmental autonomy and collective policy formation' (Chryssochoou 2009: 131). As a response to the exhaustion of state-democratic capitalism, globalization points towards new forms of coordinated social management which originate in, yet potentially override, the prerogative power of sovereign states which collectively defined the spatial and legal order of international law and politics in the early modern period. On the one hand, capitalist sovereignty resolves at a global level a tension between equal sovereignty and material inequality in a world system mediated by finance: sovereign equality is interdependent with the historical development and universalization of capitalist social relations by which the formal separation of the purely "political" states system and the "economic" sphere (the world market) was effected' (Spronk 2004: 1). On the other hand, it 'deterritorializes social forms and liberates flows of desires from restrictive codes. As it deterritorializes and decodes, it creates artificial neo-territorialities that reconcile the liberated flows from the requisites of surplus accumulation' (Gammon 2010: 368).

This problematic was examined by Hardt and Negri (2000) in a groundbreaking yet ultimately flawed study in which the authors posited an abstract conceptualization of empire as a global network of 'biopower', which dominates life in its entirety leading to a 'perpetual and universal peace outside of history'. Brilliant as their intervention was, however, the authors not only prematurely announced the death of the state (failing to anticipate the enduring relevance of spatial and legal boundaries for globalization in the absence of a single binding juridical value beyond the capitalist logic of equivalence), but failed to specify how capitalist sovereignty - as an immanent 


\section{4}

Capitalist sovereignty

and deterritorializing constitutive force expressed through the homogenizing, centralizing force of striation (patterning/rendering/homogenizing) - is reconciled with the transnationally constituted geopolitical power of the Anglosphere as it struggles to delay the inevitable transition to a multipolar global growth system presupposed by corporate globalization. Whether advanced by cheerleaders or critics of the Washington consensus, however, accounts of global order as a seamless totality without an exterior governed by a single disciplinary logic must be rejected if we are to explain the interrelationship between state territoriality and corporate power, and the persistence of space for the valorization of financial capital (Mezzadra \& Neilson 2013).

To explain the emerging institutional form of transnational corporate power it is necessary to go beyond the sweeping generalities of post-Marxism to investigate how capitalist sovereignty is instantiated at a regional and transnational level, colliding with older articulations of legal and political regulation embedded in the nation form as a fetishistically constituted territorial unit. As Robinson argues, states are 'social relations that have historically been territorialized but those relations are not by definition territorial' (Robinson 2007: 15), yet states fulfil an indispensible function in the reproduction of capitalist power. Contra Hardt and Negri, the theory of capitalist sovereignty must be grounded in a more comprehensive theory of global corporate power supported by state actors, rather than a 'plane of immanence' juxtaposed to the transcendental sovereignty of states: as the most advanced form of human social organization, transnational corporate power constitutes an agent of globalizing capital which transgresses historic territorial sovereignties yet cannot exist in unstriated space - that is, cannot overcome barriers to accumulation in unsecured space at risk from a potential 'deviation from the dominant that enables the generation of new subjectivities and forms of community' (Gonzaga 2009: 34).

While non-capitalist social forms provide fertile soil for the global violence of capital accumulation, as Luxemburg (1913) argues, capital does not expand without the infrastructural support of non-capitalist structures which it then assimilates and degrades. In this respect, Deleuze and Guattari's (1977) work on deterritorialization remains a key resource for explaining the non-linear transition from a 'primitive socius' (the despotic machine) which resists decoding/striation to a 'deterritorialized socius' (the capitalist machine) characterized by a 'general axiomatic of decoded flows'. The contemporary form through which the latter is realized is capitalist globalization, yet the world system 'includes among its elements the various nation-states which play a crucial role in the regulation of capital movements and in the realization of surplus value' (Patton 2000: 95). Deleuze and Guattari recognized that deterritorialization is ultimately inseparable from correlative reterritorializations', a geoeconomic process discernible in the spatial fixity, embedding and rescaling which structure capital flows as state space and world space incorporate "precapitalist landscapes with specifically capitalist sociospatial configurations', and where frameworks of capitalist organization 
are intertwined with historically specific patterns of uneven development insofar as [this] entails the systematic privileging of some locations, places, territories, and scales, and the marginalization and exclusion of others' (Brenner 2011: 106).

Before proceeding to an evaluation of corporate power (Chapter 3) and its global state form (Chapter 4), our first task is to define the 'objective subjectivity' of capital. Capital is a complex category - a dynamic and selfperpetuating value which constitutes the directionless, nihilistic subject of modernity as value-augmentation for its own sake. In Marxist scholarship capital exists in the process of exchange as a value that expands through circulation, but capital also possesses a relational dimension reflecting the social relations of power which facilitate the production of value through the labour process and through financialization.

Van der Pijl disaggregates the self-perpetuating logic of capital into three phases: (i) original accumulation - the 'stamping of the commodity form on social relations'; (ii) production - the subordination of labour-power and creativity to the process of expanding value (valorization of capital); and (iii) social reproduction - the subsumption of the biosphere to the requirements of capital (Van der Pijl 2001: 2). Marx theorized capital as a structuring force that subsumes economic and cultural processes to its own determinate logic yet possesses no fixed directionality or rationality beyond the incessant drive to accumulate. Capital is not a static entity or quantity in the everyday sense that an individual may be said to 'hold' commodities, equities or securities with definite values; it is, rather, a 'mode of power' driven by a logic of accumulation derived from the legal right to exclude - that is to say, from the capacity of capitalists as agents of capital combined in joint-stock ventures protected by the principle of limited liability to remove valued resources from general societal use. 'Objective subjectivity' implies volition and cognition, and it is admittedly difficult to attribute volition or cognition to an abstract mode of power, no matter how dynamic or constitutive. Yet capital does indeed have the quality of subjecthood: a form of subjectivity that is simultaneously dynamic yet involuntary and unconscious.

In philosophy, subjectivity is typically defined and determined by the limited range of free actions open to actors, and debates on free will/determinism are concerned primarily with those actions for which we hold individual agents morally accountable. Marx, on the other hand, was interested in the preconstituted structure and constitutive dynamics of commodity-determined societies, and outlined a systematic account of the social and economic processes in history that are determined independently of human moral agency while indicating those aspects of collective existence that might be changed through praxis - although this concept was left for philosophers such as Bloch (1959), Feenberg (2014) and Marković (1974) to develop more fully. Marx's conception of subjectivity is revealed in The Poverty of Philosophy, where he criticizes Proudhon for romanticizing the artisan as the 'master of the means of production': 
The producer, the moment he produces in a society founded on the division of labour and on exchange (and that is M. Proudhon's hypothesis), is forced to sell. M. Proudhon makes the producer master of the means of production; but he will agree with us that his means of production do not depend on free will. Moreover, many of these means of production are products which he gets from the outside, and in modern production he is not even free to produce the amount he wants. The actual degree of development of the productive forces compels him to produce on such or such a scale.

(Marx 1936: 36-37, emphasis added)

However, not only is the producer's will restricted by the constraints posed by the historical evolution of productive forces in actual historical societies. In addition, the subject-consumers of capitalism are only 'free' to choose to the extent that they occupy a specific location in the division of labour, and their predispositions are framed by the practices of society:

The consumer is no freer than the producer. His judgment depends on his means and his needs. Both of these are determined by his social position, which itself depends on the whole social organization. True, the worker who buys potatoes and the kept woman who buys lace both follow their respective judgments. But the difference in their judgements is explained by the difference in the positions which they occupy in the world, and which themselves are the product of social organization.

(Marx 1936: 36-37)

Thus, Marx inquires, do social needs 'arise directly from production or from a state of affairs based on production [...] to choose another example, does not the need for lawyers suppose a given civil law which is but the expression of a certain development of property, that is to say, of production?' (Marx 1936: 37). A similar conclusion is reached by Wilson (1996), who observes the contradictions between bourgeois freedom and human sociality exposed in the myth of liberal individualism. Developing Marx's position in Grundrisse, Wilson notes that regardless of how particular individuals view their own life situations and choices, the private interest of individuals in commodity societies is 'bound to the reproduction of these conditions and means. It is the interest of private persons; but its content, as well as the form and means of its realisation, is given by social conditions independent of all' (Marx, quoted in Wilson 1996: 7; cf. Macpherson 1962). The commodity, argues Wilson, represents the 'freedom of the isolated individual and this a freedom to choose within the rules but not the rules themselves [...] Rather than "combination-for-itself", the commodity-form consists in "combination-initself", an association "subservient to and led by an alien will and intelligence" (Wilson 1996: 7). In Roemer's (1988) formulation, the subject in capitalist society is always free to lose. 
Yet Marx was not a philosophical incompatibilist who rejected social mediation between free will and determination. He observed that objective historical development has a logic if and only if human subjectivity is also asserted, which is to say, progress is possible only to the extent that socioeconomic development is mediated by self-directed historical actors possessed of a given synthetic and creative quality of mind able to recognize and negotiate objectively determined constraints. Progress derives not simply from objective facts such as the 'law' of the declining rate of profit or the tendency towards a concentration and centralization of capital; structures may be determinate to the extent they mark the boundaries within which effective human agency is possible, yet as Bloch warned, the socioeconomic conditions for progress are 'never completely ripe or so perfect that they are in no need of a will to action and an anticipatory dream in the subjective fact of this will' (Bloch 1959: 580). For Marx, praxis is an essential productive component of human life and he employs the term to signify free, productive self-activity through which mankind reflexively shapes society and nature, and therefore also itself.

As Feenberg comments, Marx 'represented the practical meaning of historical materialism in the form of a plausible truth: men can only change their life if they alter their mode of living, that is, the actual-concrete activities which constitute their specific existence, and from which they can only separate themselves in their imagination' (Feenberg 2014: 12). Unlike Arendt (1958), Marx rejects the Aristotelian dualism of poeisis (productive action) and praxis (critical diagnosis) which had been transformed through German Idealism into the binary of Arbeit and Ethik. In its place he substitutes selfalienated labour and authentic self-activity, stressing the historical necessity for the emancipation of alienated labour as a reflexive mode of domination (Postone 1993). It is ultimately because the "historically determined relations of production and exchange are in their estranged form also themselves products of social labour,' argues Schmied-Kowarzik (1981: 116), 'that the possibility of their overcoming is given in the overthrow of alienated relations through the consciously revolutionary praxis of associated producers'.

Yet while critical Marxists since Georg Lukács, Karl Korsch and Ernst Bloch have rejected economistic readings of Capital as a 'scientific' study of the laws of value in capitalism (denouncing the 'scientization' of Marxism as an administrative resource in favour of praxis as an epistemological category while stressing the possibility of an autonomous subjectivity for labour in an idealized discursive space where counterhegemonic consciousness can flourish), whether capital reproducing or capital transcending, human agency in capitalism occurs under conditions determined by the alienated movement of capital, just as 'fictitious capital' is still derived from value produced under capitalist conditions rather than surplus-value generated in the labour process. As Althusser (1969) observed, Marx provided an explanation for the systemic logic of commodity-determined society: in its developed form the systemic logic of capital lies in the determinate relation between its parts, and the ways 
in which these interrelations are regulated by the structuring principle of the system itself (value augmentation). Subjectivity, therefore, is always already an expression of the "qualitatively determinate material forms of productive subjectivity developed in the course of history by the movement of the real subsumption of labour to capital' (Westra 2010: 49). The dynamic subject in capitalism is not a proletariat or global multitude, but an immanent process of abstraction through which value is realized as the adequate social subject bearing the relation of capital. To make sense of this, it is necessary to reconsider Marx's theory of abstract labour as 'empty self-equivalence', namely the production of a subjectivity inseparable from its relation to value.

\section{Capital as subject}

The tension between capital-logic and historicist approaches hinges on disagreement between those who see the law of value as the structuring principle of capitalist society, a theory of the necessary inner connections between the essential social forms assumed by capital, and those who posit the subjectiveobjective act of class struggle as the main factor in historical change - and hence the appropriate focus of academic inquiry. For the former, the attempt to understand capitalism systematically means to approach it in an abstract logical fashion to reveal the 'inner laws' of capital that underlie commoditydetermined societies. For the latter, understanding capital in a concrete historical sense means to abandon the reified straightjacket of Marx's critique of political economy as a 'scientific' analysis of the law of value and to pay attention to the subjective role of historical actors whose agency extends beyond the act of reproducing the commodity-determined structure of class society through abstract labour as a socially mediating activity.

As one critic of capital-logic approaches argues, acceptance of a logic created "prior to what people do in history generates a problematic trade-off since theory is "explanatory" only to the extent that people do not alter substantially what was defined abstractly' (Knafo 2002: 148). Defenders of capitallogic approaches, on the other hand, argue that what is being explained is the agency of people whose social relations are reified by the logic of capital, irrespective of whether their actions 'interfere' with that logic - which, if history is to change, presumably they must. For the purposes of the present discussion, it is unnecessary to unravel all the complex issues in this debate, which would inevitably require a separate book. Yet we must first define in non-opaque terms the material logic of capitalist sovereignty as a precondition for global corporate power, in order to identify a materialist geopolitics consistent with globalization. It is necessary, therefore, to consider capital in its pure form as a sovereignty unconstrained by spatial or natural limits, before interrogating the changing structure of global finance and the implications of decentred globalism for Western hegemony.

In contrast with poststructuralism, which stresses the absence of any originating source of action, the purpose of our investigation is the totalizing 
power of capital as the subject of modernity. While writers associated with the 'new' global political sociology (Urry 2003; Nash 2010; Taylor 2010) offer illuminating insights into the fragmentation and individualization of agency in global capitalism, the cultural turn in social science is rejected, for neither pluralism nor poststructuralism is adequate to a systematic critique of the corporatization of political power and the alienated form of commodity relations in the corporate economy. On the one hand, pluralists remain tied to a polyarchic model of liberal capitalism that has been refuted by critical elite theorists and neo-Marxists (Domhoff 2014; Lukes 2005). As Rueschemeyer et al. (1992: 297) argue, in Western democracies the 'economically powerful are able to exert sufficient control over the political process that political decisions rarely challenge their interests'. Neopluralism quickly collapses into an eclectic mix of neo-Marxist and functionalist propositions, conceding the structural determination of action while retaining a neo-Parsonian general theoretical scheme. On the other hand, postmodernists highlight weaknesses in evolutionary and progressivist approaches, yet their focus on identity leads to a dramatic underestimation of the continued relevance of state power in the reproduction of capitalist hegemony in the advanced economies, where despite the appearance of diversity a genuine plurality of power sources is in decline, weakening the ability of social movements to challenge concentrations of power organized through the state. As Nash (2010) concedes, in the academic stampede to establish how the site of political action has shifted from fixed institutions to non-state actors there has been a tendency to place excessive emphasis on symbolic resources and 'alternative repertoires of contention'. This extreme decentring, suggests Taylor (2010: 21), means the cultural turn has 'little to say about the complex ambiguities generated by the insertion of these political forms into a context of complex and globalized hypermodernity'.

While the cultural turn is rejected as unsuitable for explaining the social logic of corporate power in neoliberal capitalism, so is traditional Marxism. For while the grand modernizing project of liberal modernity has proven ultimately self-limiting - if not self-annihilating (Wagner 1994) - the revolutionary expectations of Marxism anticipated in the polemical works of Lenin, Trotsky and Luxemburg have been refuted by history:

on the one hand the world is more overwhelmingly capitalistic than ever, and so to that extent [...] the fundamental categories of Marx's critique, as the thinking of capital, remain indispensable; on the other, politically the world looks more like neo-Realism than it does anything envisaged in the Communist Manifesto. World-spanning capital does not generate its own supersession from within itself but produces an ungoverned international political space comprising a multitude of sharply delimited nation-states, identical 'units' iterated across the globe.

(Davenport 2011: 6-7) 
The historical trajectory of capitalism, argues Davenport, has 'superseded the kind of theory intended to transform it [...] The theorising that it was once thought would lead beyond the condition of unfreedom that Realism is a part of has failed' (Davenport 2011: 46). However, he observes, although history has 'passed by' the revolutionary Marxist vision of international class struggle, it also reveals a 'mute Marx':

the negative, critical element of Marx's thinking, more clearly; a Marx whose themes - critique of ideality [sic], of capital, of domination, and of society as second nature - have a depth and resonance beyond his own subjective understanding of them. It is this element that thinks the objectivity of society and history most deeply, and that still demands interpretation. After Marxism, Marx becomes more, not less, radical.

(Davenport 2011: 8)

The early Marxist assumption that crisis would yield appropriate economic conditions for a transition to global socialism is clearly erroneous, for in corporate globalization political reaction is omnipresent: private economic power and cultural nationalism have emerged as two self-reinforcing narratives in the discursive organization of postliberal capitalist society, and as the precarization and casualization of employment confronts manual and intellectual workers, the working class as a 'class for itself' is collapsing as atomized workers are reduced to petty commodity sellers - 'squabbling wage-slaves fighting over the table scraps of capital. Each is compelled, under penalty of starvation, to employ every advantage - race, nationality, language, religion, gender - for survival' (Eaves 2011: 3). The middle-class 'precariat', on the other hand, which reproduces the system of value and value hierarchy as a 'referent point' of commodity capitalism, is no longer capable of instigating or advancing progressive social change because the sociological category 'middle class' denotes a 'stratified field of subjectivity disciplined to a large degree to the norms of a modern society in which capital has a fundamental role in organizing social production through disciplinary markets, enclosures, governance and its profit-seeking enterprises' (De Angelis 2010: 960; cf. Buck 2008; Lazonick 2013).

Postone (2003: 95) theorizes capital as a totalizing subject that 'generates ceaselessly what is "new," while regenerating what is the "same", namely value. Although the epiphenomenal axioms of capital (trade unions, welfare, financial regulation, etc.) produced by successive capitalist cycles appear or disappear following each new crisis, capital continually reproduces value through the augmentation of new spatiotemporal conditions for the valorization of capital. Once a new limit is posited, argues Patton (2000: 96), capital 'approaches this limit only to displace it further ahead by reconstituting its own immanent relative limits'.

Moving beyond narratives of class which proceed from the transhistorical standpoint of labour (labour as a generic social category in the production of 
use values), Postone argues that neither class exploitation nor private property constitute the 'fundamental' features of capitalism. In contrast with Lukács (1923), who developed an otherwise penetrating critique of modernity in his study of reification, Marx categorized the subject with 'reference to social relations constituted by the forms of objectifying practice grasped by the category of capital'. Marx's theory of the Subject with reference to the category of capital, argues Postone, indicates that the social relations at his critique's centre should not be understood essentially in terms of class relations but rather in terms of the social mediation expressed by categories such as value and capital' (Postone 2003: 86, emphasis added). Lukács recognized that Marx's goal in Grundrisse was to explain how qualitatively distinct products of an historically specific form of labour become quantitatively equivalent to all other products. Yet, despite the brilliance of his materialist appropriation of Hegel, Lukács reads the commodity form in traditional Marxist terms as a general framework based on a theory of class exploitation in which he identifies Hegel's Geist with the proletariat as the identical subject/object of history. Lukács imputes to the proletariat an objectively possible class consciousness unimpaired by reified relations, an approach informed by Weber's ideal types, yet posits the rationality of action beyond the immediacy of the individual to the 'action of a class as a totality' (Frisby 1992: 93).

For Postone, labour and the extended process of reproduction it requires and instantiates are not simply detached from capital in a workers' state because socialism is possible only through the abolition of abstract labour as a socially mediating activity which creates an objective form of domination. 'Really existing socialism' in the Soviet Union failed to eradicate or transcend the capital relation, attempting instead to mediate it through the state and impose centralized state control over all areas of social, political and cultural organization. The result was 'socialist rationalization', complicated by the efforts of 'socialist labour science' to design new forms of labour organization to compensate workers for the elimination of labour tasks with a conceptional dimension that would otherwise limit the authority of management over production (Offe 1976).

Traditional Marxism is inadequate for four reasons: first, it falsely reduces emancipation to overcoming unjust distributions of resources (to be corrected through patterned redistribution); second, it proceeds from the transhistorical standpoint of labour as a timeless activity mediating metabolic exchange between society/nature; third, it ignores the complex determination of sociopolitical and ideological phenomena through the commodity form; and fourth, it misses the point that there is no need to posit a unified global capitalist class because corporate power constitutes itself as a radically decentred subject - as an organized system of transnational profit-making capacities indifferent to the determination of use value. An adequate account of capital as subject must therefore explain the objectification of institutions and practices in global capitalism through a formal analysis of the 
marketization of global exchange, and the rescaling of capital flows and production. With the rescaling of production and the intensification of flows in the global economy, hegemony is no longer consistent with the 'imperial' authority of states, but with the determinate logic of capital flows expressed in the reified form of capitalist commodity relations. Capitalism is ontologically unique, 'inasmuch as it is constituted by a qualitatively homogeneous social "substance" [... Preceding] social formations are not so totalized; their fundamental social relations are not qualitatively homogeneous' (Postone 2003: 87). These relations cannot be 'grasped by the concept of a "substance", cannot be unfolded from a single structuring principle, and do not display an immanent, necessary historical logic' (ibid.).

Attempts to explain capital as a totalizing subject require a closer appreciation of the philosophical and methodological parallel between Hegel and Marx as two of the most important theorists of modernity (Murray 1988; Habermas 1987; Schmidt 1971). Central to the lineage of Marx and Hegel are the structures of reason appropriated by the former in his reading of the Science of Logic, a systematic study in non-formal logic in which the third term of each successive categorial triad in the development of thought concludes by integrating (or 'sublating') the first two terms via the continual resolution and re-emergence of contradiction (thesis/antithesis/synthesis). This dialectical method was applied by Marx in Grundrisse to elucidate the 'organic unity' of capital, and Hegel's ordering of categories is reflected in Marx's ordering of economic categories in his mature critique of political economy (Meaney 2002). Marx substitutes movement of exchange for movement of thought, leading to the development of value in and for itself as capital (Arthur 2002: 89). The contradiction resolved by the mode of exchange in commoditydetermined society is that which exists between sociation (the immediate social contextualization of production) and dissociation (atomization of commodity-determined society which separates historical actors from the use values necessary to satisfy general social needs). The immediate function of exchange is qualitative: the acquisition of socially useful goods, yet this is disrupted by the fetish character of the commodity form which connects the 'materiality of the capitalist social relation to the way this relation is cognitively apprehended' (De Angelis 1996: 12). As a consequence of the commodity fetish this qualitative and localized reciprocal act gives rise under the capital relation to a more powerful self-augmenting value, namely exchange value: the quantitative value of acquiring a commodity not for its utility or intrinsic value but its value to be realized through future exchange (i.e. through a process of capitalization), as a result of which 'all its natural properties are extinguished' (Marx 1973: 141).

To progress from a simple aggregation of isolated acts of exchange to a self-reproducing market, exchange value necessitates the emergence of money as a universal equivalent posited as a value in and for itself. It is here that the conditions of possibility for the emergence of money (and ultimately global money) take shape - that is, for the emergence of capital as a self-valorizing 
value distinct from the contingency of simple commodity circulation based on the medium of money (expressed as $\left.C-M-C^{\prime}\right):^{2}$

Starting from money [on the other hand] gives rise to the movement (M-C-M'), and therewith a systematic advance is made possible in the interweaving of money and commodities, namely that the $M-C-M^{\prime}$ circuit has built into it greater possibilities of continuity and self-reproduction than the $C-M-C^{\prime}$ circuit. Value is now immanent in the activity of exchange; it is itself the object, not the effect and medium of other motives. With the form of capital, value becomes its own end rather than mediator of other relations; that is to say with capital we have before us an individual subject.

(Arthur 2002: 102)

Marx's mature social theory developed from Hegel thus reveals what capital would be if it functioned unconstrained in accordance with its own immanent principles. For, since value is nothing more than pure quantitative form, the telos of capitalist production is the limitless augmentation of value irrespective of its social and environmental costs. The money form facilitates the intensification of capital through the inversion of simple commodity production $\left(C-M-C^{\prime}\right)$ into the more complex capital relation $\left(M-C-M^{\prime}\right)$, as a result of which abstract socially necessary labour subordinates concrete labour, leading to the separation of needs and capacities, while eliminating all other possible rationale for exchange except one: quantitative gain (Kay \& Mott 1982: 56-7; cf. Foley 1986).

The restlessness of capital is thus a function of its continual need to expand, for the single goal capital is capable of realizing is value augmentation, 'a onedimensional purely quantitative measure of its achievement which negates all content' (Arthur 2002: 141). The 'true infinite' of capital derives from its selfmovement: as self-valorizing substance and subject, capital proceeds from itself and, to continue being itself, must become continually larger. As Marx put it, the 'only utility whatsoever which an object can have for capital can be to preserve or increase it' (Marx 1973: 270), and for this to occur, the complex circuit of capital must differentiate itself from a simple circulation of commodities. Marx distinguishes capital from simple circulation because in capitalism exchange value "preserves and perpetuates itself in and through circulation', which, argues Arthur, 'entails a form of exchange-value-creating production which presupposes circulation as a developed moment. In this "self-movement" of the creation of exchange values, there is a "return to the point of departure", i.e. production' (Arthur 2002: 49). By means of this process, production posits circulation and 'presupposes it in its "constant return to itself in order to posit it anew". This new mode of production arises from, and is imposed on, an older mode, from sources external to it' (ibid.: 49-50).

Although as a mode of power capital may flourish on the basis of bonded labour, the self-expansion of capital is typically dependent on the 
commodification of labour-power as a condition of possibility for future value-positing activity, a capacity appropriated by capital in its drive to selfexpansion and self-supersession through the generation of surplus-value. It is also contingent on the economic socialization of human agents as mutually suspicious rivals who continually strategize and monitor each other's behaviour, creating a society of privatized corporate agents incentivized by material gain. Unlike previous forms of political organization, however, the object of capital is not territory as such, but 'value, the commodity form of private property where this has become a type of convertible abstract right, an entitlement to profit share, a futures contract or a financial derivative' (Patton 2000: 102). As the objective subject of modernity, capital rationalizes inchoate social and cultural forms to appropriate the results of human industriousness and creativity, although this appropriation is unstable in the absence of corporate social organization and incoherent and defenceless in the absence of its state form.

\section{The tyranny of abstraction}

Commodities are bought for their qualitative specificity but exchanged as social means, generalized at a societal level as a social mediation not comprising multiple forms of abstract labour but as socially total abstract labour (gesamtgesellschaftliche Arbeit). For the purposes of the present discussion, the self-movement of capital as the structuring principle of modernity (and hence its objective subjectivity) is based on the emergence of the commodity which contains in its own structure an accretion of use values that are continually superseded to create a higher form of use value which is simultaneously a specific quantity of exchange value. Marx is clearly indebted to Hegel for his analysis of the self-valorization of capital as a self-causing agent which, through its own self-positing and self-expansion, is actualized as a totality which in turn imposes an objective structure of social domination over human existence. However, in contrast with Marx's own initial synchronic presentation of capitalism as a 'fully formed' system based on the law of value, historical capitalism as a mode of production specific to the advanced societies has only come into existence in a gradual and contingent form, and has only developed fully where labour-power is able to evolve properly into a self-mediating commodity and thus where the commodity form becomes 'totalizing'. Yet Marx's enduring achievement was to apply Hegel's method in a radically inverted form to reveal the 'tyranny of abstraction' in commodity-determined society:

$[T]$ o the degree that Hegel's notion of the Subject does have historical and social validity, according to Marx, that Subject is not a concrete human social agent, collective or individual. Rather, the historical Subject analyzed by Marx consists of objectified relations, the subjective-objective categorial forms characteristic of capitalism, whose 'substance' is abstract 
labor, that is the specific character of labor as a socially mediating activity in capitalism. Marx's Subject, like Hegel's, then, is abstract and cannot be identified with any social actors. Moreover both unfold in time in a way that is independent of human will.

(Postone 1993: 76)

This point is articulated by Marx in Grundrisse, where he considers the geoeconomic consequences of capital accumulation as a process of selfrealization:

while capital must on one side strive to tear down every spatial barrier to intercourse $[\ldots]$ and conquer the whole world for its market, it strives on the other side to annihilate this space with time, i.e. to reduce to a minimum the time spent in motion from one place to another. The more developed the capital, therefore, the more extensive the market over which it circulates, which forms the spatial orbit of its circulation, [and] the more does it strive simultaneously for an even greater extension of the market and for greater annihilation of space by time [...] There appears here the universalizing tendency of capital, which extinguishes from it all previous stages of production.

(Marx 1973: 539-40)

This insight has been developed by theorists of globalization like Harvey, who notes that a 'reduction in the cost and time of movement has proven a compelling necessity of a capitalist mode of production' (Harvey 2003: 98). To this end, he adds, 'the evolution of the geographical landscape of capitalist activity is driven remorselessly by round after round of time-space compression' (ibid.).

Capital therefore becomes a force independent of living labour and possesses the 'objectivity of a subject distinct from living labour capacity and standing independently over against it' (Marx 1973: 462). Through abstraction, capital as 'dead labour' operates as a social mediation - a homogenous substance derived from alienated social relations 'constituted by structured forms of practice [that] acquire a quasi-independent existence and subject people to determinate quasi-objective constraints' (Postone 1993: 80). With the concentration of capital, all aspects of society and culture become embedded in this mode of power. Despite the gross iniquity of global capitalism, this is not the traditional authority of a minority over the majority, but the impersonal, self-reflexive domination of individuals by their own position in the division of labour. Domination in capitalism is grounded not simply in class relations, but in the "pervasive structuring social forms of capitalist society that are constituted by determinate forms of social practice' (ibid.: 159), that is, the capitalist form of alienated labour which brings into being a social system defined by the 'quasi-independent, abstract, universal Other that stands opposed to the individuals and exerts an impersonal compulsion on them' (ibid.). 
Yet this abstract domination is concealed through a process of naturalization that presents labour as transhistorical, as a natural rather than historically determinate necessity. This insight into the objectivity of capitalist domination highlights the constitutive power of capital as a causal force that arrests consciousness in societies governed by the power of spectacle, which Agamben (1993) defines as 'capital to such a degree of accumulation that it becomes an image' (in Barkan 2009: 249). In the society of spectacle, capitalist relations develop to the point that human life is 'governed by exchange value; even use value itself has become indistinguishable from its representation as exchange value', where the 'economy expands to a dominant position over all other spheres of social life' (Barkan 2009: 249; cf. Gorz 2011). Capital directs culture towards a monolithic telos of value augmentation - towards a one-dimensional rationality that incorporates workers who relate to themselves as 'object[s] opposed to and enabling capital to exist for-itself as subject and as subject[s] opposed to and enabling capital's internal differentiation as object - as capital's constitutive outside and vanishing mediation throughout the entire process' (Gawel 2012: 4). Through capitalist subjectification - through the performance of abstract labour as a lived process of reification - the worker

relates to himself as the very abstraction by which capital relates to itself, and this is the ground of both his specificity in the original exchange as naked object and free subject relating only to itself in its independence, and also his negative auto-relationality as a pure generality without identical sameness, the literal undoing of the ideological self-equivalence entailed by the contract. His individuality thus is both poverty and generality, in each case the negative image of capital as the subject of its own process of valorization.

(Gawel 2012: 4, emphasis added)

The process of valorization is thus both equally disempowering and totalizing, for the 'abstract individual - a processual relationship of domination that negates its relational origins by propagating itself as its own formal equivalence - has been capital's form throughout' (Gawel 2012: 4).

Arthur accepts with qualification the assertion that capital can be considered a 'self-constituting Subject' based on a single structuring principle: 'Whereas a simple inversion of Hegel produces a materialist philosophy of history founded on some a priori dialectical schema', he notes, Marx's critique of political economy denotes the forms that Hegel's concepts absolutize and idealize. "In these forms a historical "logic" can indeed be seen; but it is one restricted to the parameters of capitalist development, because its social forms are uniquely constituted through material abstraction in a way that grounds a dialectic' (Arthur 2004: 94). As the objective subject of modernity, capital is thus a material abstraction of the value form which unfolds independently of human will - that is to say, unfolds in ways that are less 
responsive to human agency during periods when the system achieves a state of 'normal functioning', but which may become more susceptible to human agency as the system begins to fail (cf. Wallerstein 2010, 2011a).

Yet Arthur is critical of the indeterminacy of the notion of capital as an unself-conscious quasi-Subject without cognition. This raises questions about the nature of agency, for what kind of subject has no self-consciousness or self-knowing? Such agency might be attributed 'to animals whose activity secures their subsistence, just as capital bent on self-valorisation preserves and increases its "substance" through reflexively incorporating its increment. But is this tendency to self-preservation enough to constitute a subject?' (Arthur 2004: 94). Arthur is also critical of Postone's interpretation of the term substance, which has more than one meaning. In particular, we should distinguish between substance as material form and substance as self-constitutive force - something that exists on its own account - and he questions Postone's failure to specify whether labour or value is fundamental to the totality. If capital is a subject, he argues, 'and only its totalising activity posits value as an actuality and abstract labour as a practical truth, then it seems plausible to argue that labour is not the self-mediating social ground, but rather a moment in the self-mediation of capital, with value as both origin and product of this subject' (ibid.: 98). Marx posits the self-constitutive power of capital: abstract labour is understood as the substance of value, and Postone may be in danger of placing the cart before the horse, so that capital posits itself as its own product. Finally, Arthur is critical of Postone's failure to emphasize class struggle as if labour were fully integrated into the logic of capital. Against this view, he insists, we must recognize labour is at once in and against capital; bearers of its forms to be sure, but always incipiently in revolt against such "interpellation" (Arthur 2004: 101). Labour is not identical to a "class of labourers', and although Postone is correct to emphasize the integrality of labour as a category for the totality, this does not disqualify the 'proletariat from forming itself as a counter-subject to capital [...] no one is more aware of this than capital itself which certainly does not rely only on "dull economic compulsion" to secure labour services' (ibid.: 101). This is echoed by Albritton, who argues that Postone fails to consider the condition of labour in his totalizing narrative of self-valorizing value: 'If we follow through with his claim that "Marx characterizes capital as a self-moving substance which is Subject", he contends, "the result will be a theory which represents the selfunfolding of capital, or, in other words, capital's theory of itself' (Albritton 2004: 81).

These criticisms are apposite and must be considered before proceeding with our analysis, yet do they not substantially weaken Postone's critique of traditional Marxism or his theoretical conceptualization of capitalist subjectivity as a form of non-intentional causality which produces outcomes consistent with the self-expanding logic of capital as a mode of power rather than simply class actors. ${ }^{3}$ Both Arthur and Albritton are right to question the apparent functional automaticity of Postone's approach, which seems to rule 
out all political opposition to capital by reaffirming the absolute causality of value. Furthermore, as Feenberg argues, Postone's depiction of 'traditional Marxism' contains elements of caricature: far from being idealistic, Lukács's intention was to demonstrate how, 'starting out from the specific degradation of its life and work under the reign of the law of value, the proletariat can break with capitalist forms of thought and action and realize the potentialities for a very different type of society contained and repressed in capitalist industrialism' (Feenberg 1996: 609). In addition, few activists could feel inspired by Postone's gloomy professorial exegesis of Marx's social theory even if he is correct to argue that capitalist temporality pushes the rate of technical and financial innovation to the point where labour becomes less important for the generation of surplus-value (cf. Marazzi 2010). Yet, as Starosta argues, the essential importance of Postone's intellectual contribution lies in his argument that, if

concretely and consistently developed, the mature Marxian notion of alienation amounts to the social constitution of capital as the (alienated) concrete subject of the historical movement of modern society. The essential determination of social reproduction in its capitalist form is to become totally subsumed under [...] the autonomized movement of selfvalorizing value, thereby determining human beings as 'personifications of economic categories', that is, objectified social relations.

(Starosta 2004: 45)

Furthermore, he adds, 'this personification does not derive from an uncritical relapse into the abstract principles of structural-functionalist methodology'. On the contrary, it 'necessarily follows from a consistently materialist understanding of the specifically capitalist inverted constitution of practice underlying both the forms of objectivity and subjectivity of present-day social life' (Starosta 2004: 45). The error of traditional Marxism is that it only 'provides an objective context which is seen as spurring, accelerating or facilitating the self-determining movement of the subjective factor [...] there is no real mediation between the materiality of the production process of human life and the political consciousness of the emancipatory subject' (ibid.: 49). On the contrary, even if radical political practice is not diverted by nationalism, religious sectarianism or consumerism, anti-capitalism in its fundamentalist and pragmatic varieties is typically founded on progressive forms of misrecognition where 'movements are blind to the larger context of which they are a part [and thus] generate consequences that are undesirable for them as well' (Postone, in interview with Blumberg \& Nogales 2008).

Capital is a value that is self-activating, 'both substance and subject' (Murray 1988: 216). In addition, the circuit of capital should be seen as performative: capital is a constantly mutating substance and subject which is 'always engaged in experiment, as the project is perpetually unfinished' (Thrift 2005: 3). The singular monolithic telos of capital can be better appreciated by 
considering the structural limits placed on value augmentation not simply by the barriers to production of a given value but by the effects of a separation of wealth from the circuit of capital (hoarding/demand for liquidity), which leads in turn to disinvestment and recession. Capital must continually reproduce itself anew by producing commodities drawing on the stimulated demand of consumers, for the "particularity of the commodity has to be converted into the universality of money which is much more problematic than going from money [...] to commodities. Somebody must need, want or desire the particular commodity' (Harvey 2010: 106). The constraints imposed by competition on the expansion of value are insufficient to deter capitalists from introducing new commodities by creating new needs to overcome the barriers of existing markets (Clarke 1989: 13). Idle capital is dysfunctional, for as McNally observes, 'every finite form of capital as a sum of money stands as a barrier to capital's drive towards infinity, its telos as absolute wealth. Inherent in capital', he argues, 'is an unending process of self-negation; capital drives beyond its previous limit only to find itself separated from its goal: absolute wealth' (McNally 2003: 6). Capital cannot capitalistically produce its own 'vital presupposition', and its sovereignty is therefore constrained by given structural variables reflecting the cultural and political organization of market economies. The 'solution' developed by capital is to

strive endlessly to negate all the limits imposed upon it by actual usevalues, to try to overcome its own fixity (finite determination) by reducing the time spent in the sphere of production [...] If it were possible - which it is not - capital would take leave entirely of the sphere of production of use values in order to assume a 'pure' form of money breeding money; it would utterly annihilate space in favour of time.

(McNally 2003: 8)

One response to this conundrum is the creation of credit markets which, by selling (or creating ex nihilo) the universal commodity form of money, allow capitalists access to capital to finance innovation and further reduce dependency on living labour. Another is globalization which accelerates the 'socialization and global integration of capitalist production, whilst constituting a powerful means of economic and social restructuring' (Liodakis 2010: 46). Neoliberal financialization has led to an economic transformation of advanced economies based on the expanded role of finance relative to other spheres of activity, where: (i) non-financial corporations reduce reliance on bank capital to acquire financial capacity for themselves; (ii) banks extend their mediating activities in financial markets; and (iii) households are integrated more intensively into the debt/credit nexus of capitalist finance (Lapavitsas 2011; Brown 2010).

Debt is not in itself an impediment to economic growth, but the debtcreation system that compels the process of financialization constitutes a relation of power: "a "capture", "predation", and "extraction" machine for 
macroeconomic prescription and management', and hence a 'mechanism for the production and "government" of individual subjectivities' (Lazzarato 2012: 29). Developing Nietzsche's genealogical investigation into the origins of the dual phenomena debt/guilt (in German both concepts are signified by the word $S$ chuld), Lazzarato argues perceptively that debt not only facilitates the purchasing power necessary to sustain capital, but socializes consumers into 'correct' forms of subjectivity necessary to sustain the debt (power) relation itself - to remain 'free' (despite the guilt/burden of being in debt), and able to 'act in such a way that you are able to honour your debts even if, like the IMF, it has a tendency to devour "debtors" by imposing economic policies that promote "recession"” (ibid.: 31).

Financialization announces the moment when capital becomes potentially self-constitutive (M-M'), although this moment may be short lived, for as McNally argues, in spite of the appearance of limitless self-valorization,

speculative capital can no more escape the dynamic of bad infinity [movement towards an infinite destination that is never actually fulfilled] than can any other form. Every financial crisis and stock market crash represents a revenge of the finite as interest-bearing money discovers its infinite ties to the finite world of use-values. After all, fixed capital and fictitious capital are two interconnected extremes within the contradictory unity of capital as a whole.

(McNally 2003: 12)

'Revenge of the finite' notwithstanding, however, the expanding systemic role of finance in the transformation of global capitalism reveals the objective subjectivity of capital as a constitutive mode of power: in an era defined by accelerated global flows, extraction and speculation, and the increasing role of language and mnemotechnics ${ }^{4}$ in the sphere of exchange (Marazzi 2011; Stiegler 2010), we are witnessing the emergence of a purely quantitative logica logic of valorization that requires the "plundering of all other potential values of the earth' (Elsner 2012: 133). On the one hand this leads to a subjugation and subsumption of autonomous forms under the value relation, substituting a one-dimensional rationality for autonomously grounded values/ codes that underpin communities. On the other hand, this increases the potential for geopolitical conflict as corporate-state interests maximize opportunities for new sources of accumulation as rates of profitability decline.

The quantitative logic of financialization is typically justified in financial economics through a synthesis of 'efficient market theory' and 'portfolio optimization theory', neither of which reflect the imperfect function of capital markets which periodically defeat themselves by diverting excess surplus capital (the accumulated surplus corporations cannot invest productively) into overinvestment in credit markets and the innovation of complex financial instruments which assume 'all products of human economic activity' and risk can be efficiently priced (Nesvetailova 2013: 70). However, the realities of 
leveraged finance and the unstoppable growth of shadow banking (where asset deals and loans are conducted off-balance sheet to maximize returns and avoid the intended effects of intensified regulation) indicate the de facto limits of transnationally constituted public authorities (the IMF/Bank of International Settlements, etc.), to reduce risk and control 'financial innovation' which is increasingly a 'front for borderline practices and outright fraud, the sole purpose of which [is] self-enrichment of financial institutions and banks' (ibid.: 71).

As Haiven notes in an insightful essay, if the purely quantitative logic of value seeks to co-opt the 'dense world of qualitative social values under its cyclopean logic of quantified economic value', then the modern structure of finance should be understood as the 'redoubling of the complexities and abstractions of money [which] creates a world-embracing matrix of signals that allows for a form of synthetic comprehension of social totality and futurity' (Haiven 2010: 93). Financial capital is a destabilizing force, yet also functions as capital's 'imagination' - a more complex moment of the capitalist abstraction of value (ibid.: 94). Anxious not to anthropomorphize a category without self-consciousness, Haiven argues that capital has "no agency of its own but is a durable pattern that profoundly influences people's agency, subjectivity, expectations, and dispositions toward actions that reproduce and expand capitalist social relations' (ibid.: 98-99, emphasis added). He notes furthermore that the logical function of global finance is to resolve a contradiction between capitals through combination, effectively 'pooling the surplus value they have extracted from labor and putting it toward geographically or temporally distant projects that no single capitalist agent can afford to risk'. While it appears finance has a 'will of its own', however, it is a 'complex means by which the abstract system of capital - which is, after all, an imagined presence given real-world power by its influence on human actions subtly mobilizes, disciplines and coordinates the agency of social actors towards its perpetuation and expansion' (ibid.: 107). In the global economy finance has shed its older mercantilist form as money transcends its traditional functions as medium of exchange, store of value and unit of account. To achieve ever-increasing rates of return in a world characterized by declining rates of profit, finance must colonize new areas of human life constructing "what is liquid (saleable/convertible) in all "assets" and in the process giving once non-financial things a liquid, financial dimension to which a rate of return attaches' (Bryan 2012: 172).

This analysis bears comparison with Habermas's (1984) juxtaposition of system and lifeworld, where vital sociocultural forms are recombined through rationalization into differentiated, complex and self-sufficient systems. For Habermas, this leads to a 'colonization of the lifeworld' by an overarching structure of power driven by narrow criteria of rationality which drastically limit the capacity of agents to engage in free communication. Rationalization sustains the lifeworld within an atomized and rigidified structure, initiating a form of cultural and ecological decay which can only be reversed through the 
constitution of ideal speech scenarios where alternative technologies for life develop free from the distortion effect of unequal power.

For Marazzi, who emphasizes the centrality of language in late capitalism, linguistic-discursive mediation establishes the condition for a substantive rationality which 'allows us to justify and legitimize the governance of society by referring to collective interests and needs' (Marazzi 2011: 36). Yet, for Haiven, the instability of finance derives from its tendency to (mis)calculate value by focusing exclusively on exchange value, which explains its incapacity to articulate and measure the 'social totality of value' - a deficiency he defines as capital's 'imaginative gap' (Haiven 2010: 112). Unlike Thrift (2005), who naïvely applauds the elevated status of information workers under what he terms 'soft capitalism' (i.e. the collective brain of knowledge economies), or Hardt and Negri, who misconstrue the category 'immaterial labour' - a questionable idea which falsely accords autonomy to emancipated workers who control information flows and ideas (reminiscent of knowledge economy discourse in liberal management theory) (Sherman 2011), Haivan (2010: 115) observes that by appropriating and transforming use values into metrics of risk, financialized capitalism 'functions as a weapon of social discipline'. Imagination can only serve as a metaphor, for capital is 'inhuman and possesses no agency of its own nor any unique intelligence' (ibid.). Rather, we might say, 'capital amassed through the credit system has the potential to fine-tune the engine of accumulation through sophisticated coordination of investment decisions across an economy' (Harvey 1982: 284), and while this may lead to 'irrational forms of overproduction and overspeculation' (ibid.: 288), it constitutes the central nervous system of a complex and interdependent global financial structure that exists objectively and independently of the transitory agency of really existing historical individuals and most sovereign governments.

Liodakis acknowledges the significance of the 'general intellect' in capitalism which he grounds in the 'transformation of the mode of socialization and the social division of labour, which tend to upset formerly private commodity production and partly supersede the operation of the law of value' (Liodakis 2010: 17). Yet labour is never actually immaterial, for it is not the 'content of labour but its commodity form that gives "weight" to an object or idea in a market economy. Its physicality or otherwise is wholly irrelevant. [...] transformation of knowledge or intellect into saleable commodities relies precisely on separating knowledge from the knower' (Thompson 2005: 41). This point is critical: individual subjectivity is an 'abstraction of the social relations that produce it, which as such concretely reproduces these social relations' (Gawel 2012: 1). This mystification becomes possible because value

constitutes this ground of sociality precisely as an independent subject. Nor is this an innocent fact as value achieves this independence as the subject of its own valorization process only insofar as the individual worker $[\ldots]$ forms its constitutive outside and mediation, and as such can 
never partake in the form of independent subjectivity it casts upon her as its empty shadow [...] Labor is initially posed by capital in exchange as a propertyless object whose necessary opposition to capital is realized via its appearance as free subject, and subsequently posed in production as pure subjectivity excluded from the objective value that it produces. In being posited by capital as separate and independent from it only as object, and as originating agency as subject only insofar as it cannot take part in its own objective product, labor in each instance is formed as the reverse image of value.

(Gawel 2012: 1)

This process is vital to the separation and perpetuation of the value form as abstraction in action. For, once the process of exchange between value and labour takes place, the appearance of equality disappears, uncovering the capital relation as the 'assertion of capital's necessity to valorize itself by incorporating yet maintaining itself as opposed to what must exist outside of it as its use, namely labor' (Gawel 2012: 2). The worker, argues Gawel, is 'always ejected from the general wealth of capital through the act of accepting (and thus using) a portion of it, and in this way finds himself in need of renewing the contract' (ibid.: 2). In the same sense, the debtor - especially the sovereign debtor who defaults - is ostracized from the capital markets to find herself at the mercy of the IMF. Regardless of the materiality of specific economic processes, intellectual and manual workers are both separated from the product of their labour as capital is reproduced in new ways through the value form as a tyranny of abstraction which accelerates the universal development of the forces of production (industrial or financial) in its drive for self-expansion, but which exhibits no substantive rationality of its own and posits no logical telos beyond its own continuous self-valorization. In this sense, the tyranny of abstraction (capitalist tyranny) is distinct from earlier forms of political totalitarianism, yet is 'more subtle, more insidious, more hidden from general view' (Wood 2004: 64). As Wood concludes: 'What could be more seductive and disarming than the insinuation of the new tyranny into every facet of human reality and thought under the beguiling cover of democracy, legal and juridical equality, individual freedom, equality of opportunity, classlessness and progress?' (Wood 2004: 64).

\section{Conclusion}

If capital has no self-conscious agency, it nevertheless abstracts from the activities and mentalities of the multitude, constituting durable patterns and structures that influence subjects' dispositions, which in turn reproduce and extend capitalist relations of power. It is the logical function of finance to resolve the contradiction and competition between capitals by aggregating value and orchestrating investments that would otherwise be beyond the scope of individual ventures even to conceptualize. As we shall see, this is a 
basic organizing principle of dominant capital as the driving force of transnational corporate power in the international political economy of neoliberal globalization. Yet the constitutive power of capital is incomplete in the absence of its state form as the sphere of juridical organization that stands outside and above social reproduction yet remains integral to it. The capitalist state form is a political technology to manage: (i) contradictions between deterritorialized capitals and embedded regimes of accumulation; (ii) the tendency towards overaccumulation, where despite increasing productivity, conversion of surplus-value into capital is periodically blocked, leading to declining profitability; and (iii) geopolitical tensions created between state actors in the organization of transnational corporate power.

Developing Hobbes's characterization of the legal exemptions granted by charter to corporations to pursue the public welfare, Barkan argues that corporate power reflects the 'doubling' of sovereignty in modernity, which forces us to rethink corporate agency as a mode of political sovereignty:

corporations are legal creations - fictitious persons formed when states recognize the power of individuals to organize collectively. Corporations are fictions, created by states, but given such social power that they threaten to undermine the political sovereignty that created them. In other words, corporations are an 'imaginary relationship of individuals to the real conditions of their existence', produced by the state and law and thus, strictly speaking, ideological. They are also the means by which states attempt to marshal the collective power of individuals towards public ends by granting them a special legal status. This paradoxical relation, in which corporations emerge from law but continue to threaten the existence and legitimacy of the state, suggests something more complex than the declining power of states in the face of a global corporate economy.

(Barkan 2013: 4)

Indeed, one of the significant features of the global financial crisis is not the support of Western governments for the banking system, but the spectacle of the Lehman Brothers collapse and its presentation in corporate media discourse as a threat to national security. The global crisis that followed revealed the fusion of corporate-state power in postliberal capitalism - which Barkan redefines through the parallel logics of state sovereignty and corporate hegemony. Following Agamben (1998), he posits an affinity between formal political sovereignty as exceptional power (where rule of law is legitimately suspended to defend democracy against itself), and corporate sovereignty as legally sanctioned immunity from law (where rule of law is suspended as value augmentation reaches high levels of intensity). These dual logics which coincided in September 2008 as the US Congress passed the Emergency Economic Stabilization Act - should not be juxtaposed but seen as two dimensions of prerogative right expressing the constitutive power of capital as a 
self-valorizing value in neoliberal capitalism. This formulation offers a more reliable basis from which to comprehend the evolution of capitalist sovereignty as a mode of power - as a precondition for generating value through financial instruments that have 'little direct connection to the material economy of countries' (Sassen 2011: 43). Capitalist sovereignty augments and displaces rather than destroys the political sovereignty of states, and by exploiting legal distinctions between territorial accumulation regimes, capitalist sovereignty provides a basis for the expansion of the commodity market system at the level of the global economy.

In the next chapter, we shall examine the logic of corporate power and the development of the modern corporation as a vehicle for extending capitalist sovereignty through the legal construction of 'limited liability' and 'corporate personhood'. If, as we have argued, capital has no actual conscious agency, the same is not true with regard to the modern corporation, which constitutes a reflexive intentional system. As Gupta argues:

The agency which is contained in the manifest form of the capitalist corporation not only explains and predicts its own behaviour with a view to achieving its predetermined end, it acts upon its self-explanations and self-predictions to direct itself towards that predetermined end. This means that the agency within the corporation can effect suitable changes and modifications within its own constitution, can impinge upon its own behaviour, can moderate itself according to its own projections. One may think of the capitalist corporation as some sort of collective organic entity: self-contained, self-determining, self-projecting, self-modifying.

(Gupta 2002: 58)

Once we have examined the legal basis and political rationale of capitalist sovereignty, expressed in terms of the prerogative right of capitalist corporations to accumulate at a differential rate, we can proceed towards a more concrete analysis of the state form of transnational capital as a precondition for the expansion and consolidation of corporate power in the global economy. Global economic governance can be understood as an attempt to impose regulatory structures on capital flows, yet as the regulatory experiments that followed the global financial crisis clearly demonstrate, capital will quickly and perhaps inevitably overcome all political attempts at regulation in order to exploit unequal terms of trade and achieve above-average returns.

\section{Notes}

1 Walker (1993: 159) is critical of rigid ontological distinctions in neorealism which, he suggests, reveal the 'limits of modern political discourse in an era perplexed by temporal accelerations and historical/structural transformations. These limits are especially apparent in the categories and debates of international relations theory as the discipline most explicitly constituted as a limit of authentically political life within the territorial container of the sovereign state'. 


\section{Capitalist sovereignty}

2 Where $\mathrm{C}=$ commodity, $\mathrm{C}^{\prime}=$ new commodity, $\mathrm{M}=$ money, and $\mathrm{M}^{\prime}=$ new quantity of money.

3 As we shall see in Chapter 4, IR scholars like Wendt (2003) have attempted to combine intentional and non-intentional causality to explain the inevitable emergence of a 'world state', a form of teleological reasoning that explains the development of global economic and political integration without reference to the self-movement of capital as the real subject of corporate globalization.

4 Mnemotechnics is concerned with the 'art of memory'. Stiegler (2010: 29) defines the term as 'writing which functions as a fabricator of illusion and technique for the manipulation of the mind', contraposing dead memory to living memory. Van Camp (2012: 3) observes that for Stiegler, 'audio-visual media have become indispensable for the creation of the large scale markets required for the return on investment in research and development and industrial production. They provide access to a meta-market of millions of minds whose attention can be captured and conditioned to adopt new consumption goods'. However, he adds, while this is not a new phenomenon, it certainly is the case that 'the industrial exploitation of the mnemotechnical system which we are currently experiencing tends toward the destruction of both psychic and collective individuation processes' (ibid.). 


\section{Corporate globalization}

\section{Introduction}

In Chapter 2 it was shown that while possessing no autonomous agency as such, as self-valorizing value capital acquires an 'objective subjectivity' as a dynamic structuring force - the constitutive mode of power in commoditydetermined societies whose social function is obscured by the formal separation of property ownership and political supremacy in classical theories of sovereignty. Rejecting Marxism from the standpoint of labour, it was shown that an adequate account of capitalist sovereignty must explain not simply the global relevance of corporate capital as a causal variable in international politics but the tendency of capital to develop new economic forms and social structures while continuously regenerating the 'same' - that is, continually reproducing contingent yet functionally identical commodity-determined relations rooted in the value form. In this contingent sense, capital creates the social conditions for historical change and the juridical evolution of the national and transnational state, yet adapts its sociopolitical form to reincorporate and neutralize this modernization effect. It is for this reason that capitalist formations structured in accordance with the value relation characterized by equivalence and substitutability cannot be superseded (Mann 2010).

This is not to refute the possibility of progress, only to assert that fundamental political change cannot take place in commodity-determined societies of self-alienated labour. From this perspective, the global financial crisis promises not the end of capitalism but its reconstitution in a totalizing postliberal form (cf. Liodakis 2010; Crouch 2011; Stockhammer 2011; Hart-Landsberg 2013). Despite limited reform, the value relation has not been superseded; on the contrary, it is running at near full capacity, and critical observers who fetishize a normative distinction between real and fictitious capital 'overstate the extent and depth of the crisis for capital, and underestimate the virtually uninterrupted consolidation of the rule of the value, i.e. the territorial and historical imperative of equivalence and substitutability' (Mann 2010: 172).

Corporate globalization encompasses two manifestations of sovereignty. The first is articulated in the timeless anarchy of international relations as a 
neo-Darwinian struggle between identity-based communities of fate, articulated most forcefully in the 'friend-enemy distinction' (Schmitt 1927), where mere potential for conflict is adequate to activate war between rivals. The statecentric model of international politics is by no means redundant: the national state form of capital matters for the political organization of class power and the cultural mediation of globalizing capital (Hobsbawm 1992). The global hegemony of capital is possible precisely because capitalism is a world system that incorporates and reproduces in itself a plurality of political forms. As Wallerstein argues, 'capitalism as an economic mode is based on the fact that the economic factors operate within an arena larger than that which any political entity can totally control. This gives capitalists a freedom of manoeuvre that is structurally based' (Wallerstein 1974: 230).

The second manifestation of sovereignty is entailed in the geocentric logic of corporate globalization and the intensification of capitalist power through its transnational state form: corporations possess non-legitimate power yet their power is articulated through complex structures of global economic governance which confer legitimacy on capital as the real subject of globality. As Davenport argues, interstate relations and global corporate power 'reinforce and reproduce each other: political fragmentation facilitates the mobility of capital and the uneven development of capitalist production means that dominant classes in core powers export capital to other areas' (Davenport 2011: 26). This, he adds, restrains 'core powers from attempting to impose political dominance through conquest' (ibid.: 26; cf. Chase-Dunn 1981). These twin articulations of sovereignty are typically separated in IR and IPE, yet their intermediation is revealed in the principles of legal nonliability and political unaccountability that underpin the capitalist value form.

This phenomenon is revealed most obviously, perhaps, in the corporate impunity of private security contractors whose exceptional legal status and parapolitical function are articulated via a discourse of security/risk/expertise based on practical authority linked to experience/engagement, a discourse of market rationality based on the efficiency of private firms, and a discourse of acquired authority predicated on the incorporation of governmental functions (augmentation of states' monopoly of violence) (Leander 2010: 471-81; cf. Krahmann 2012). Parapolitics implies a 'system of politics in which accountability is consciously diminished' (Wilson 2012: 1), and with the intensification of war economy 'the marriage of government, business and military tightens; "privatization" of military functions simply comes with the terrain, as many corporations simply take on greater "battle-field responsibilities" (Boggs 2011a: 109). This permanent war system, Boggs adds, 'legitimates and reinforces state power on a grand scale' (ibid.: 110), providing additional justification for the security-industrial complex while minimizing the accountability of states for human rights violations and 'collateral damage' to civilians and infrastructure (Hoppe 2008). Capitalist sovereignty is also revealed in its opposition to 'constituent power' as the popular ground of political freedom - an always potential and recurring force which precipitates 
political change at contingent stages in the historical development of capitalism, but which typically exists outside the purview of the constituted state and is therefore indeterminate in form. As Gupta (2002: 163) observes, the 'capitalist state is such because it colludes with corporate capitalist processes'. Yet it would be misleading to argue that these articulations of sovereignty are identical, for the public authority of the state and private power of the corporation embody distinct forms of intentionality:

The means-orientation of the political state may (or may be made to) cohere with the ends-orientation of the capitalist corporation, but equally it may not. It may not precisely because ultimately the political state (with its definitive means orientation) is with regard to the people-landresources it represents, and the capitalist corporation (with its definitive ends-orientation) has no such necessary allegiance.

(Gupta 2002: 52)

This, concludes Gupta (2002: 52), 'means that two different kinds of intentionality are implied in the two definitions which may happen to complement each other but which do not coincide'.

In what follows, we analyse the logic of corporate globalization as an economic system based on differential accumulation, applying a theory of dominant capital as 'forward-looking' power (Nitzan \& Bichler 2009). We begin by examining the consolidation of US corporate power in the twentieth century as a feature of 'political' capitalism, which Kolko defines as the 'utilization of political outlets to attain conditions of stability, predictability and security [...] in the economy' (Kolko 1964: 3). In postliberal capitalism political and economic power are not separate, but rather intertwined in a single social order. The polity and economy of society are not discrete self-referential action systems as autopoiesis theory claims (Luhmann 1990), but comprise a conceptual duality reflecting the complementary right to compel obedience (political control) and exclude (economic domination) (Pels 1998: 3).

Corporate power is ontologically linked to the sovereign power of the state: as the legal embodiment of capital, corporate power is founded on legally sanctioned immunity from law, in large part because corporatism emerged as the 'inescapable horizon for securing human welfare' (Barkan 2013: 162), but also because the corporation is a powerful form of social organization which it is too prohibitive for states to bring under real public control (Wilson 2009: 19). Capitalist sovereignty, in effect, acquires prerogative right; and the transnational expansion of US corporate capitalism must count as a central narrative of modern world history, even if competing models of regional capitalism also emerged in Germany and Japan in the interwar period leading to the creation of closed political spaces (Grossraumordnungen) in Europe and Asia which temporarily threatened Anglo-American naval hegemony and Soviet land power before the establishment of a bipolar world order at Yalta. ${ }^{1}$ Although the term empire offers an appealing and analytically convenient 
basis for understanding transnational corporate power, attempts by modern states to create closed political spaces fail because they are incapable of obtaining sufficient support in a system in which expanding and deepening commodity production and the continuation of the multi-centric interstate system hold greater promise for national ruling classes than the presentiment of shares within world imperium' (Chase-Dunn 1989: 8). As a result, the 'centrality of markets and capitalist accumulation undercuts the tendency towards empire formation' (ibid.). A hegemonic state may resort to coercion to defend corporate interests; however, as global competition from emerging markets grows, unilateralism becomes less appropriate and less effective as 'capital is exported from the declining hegemonic core state to areas where profit rates are higher. This reduces the level at which capitalists within the hegemonic core state will support the "economic nationalism" of their home state" (ibid.: 147), leading to divisions between transnationally oriented and national capitals - an intra-class conflict within the transnational capitalist class (Robinson 2002, 2004a).

Our second task is to explore differential accumulation as an institutional precondition for capitalist sovereignty. Building on the economic sociology of Veblen, Nitzan and Bichler critically assess the differential power of dominant capital expressed in the monopolistic organization of markets. Differential accumulation indicates the 'ability of dominant capital, namely the leading corporations and key government organs [...] to control, shape and transform society against opposition' (Nitzan \& Bichler 2009: 17). What matters is not absolute but differential accumulation, the capacity to 'beat the average'. The aim is not productivity but control, which enables 'some agents to set the conditions under which others must act [...] undermining or even destroying the productive capacity of society in order to preserve the structural market power of dominant capital' (Scott 2001: 72). This applies to transnational oligopolies which 'influence the environment in which they operate, rather than simply react to it in an easily predictable manner like a small firm under "perfect competition" [...] By operating at any one time in a number of different economic and political environments, and, what is more, by exploiting these differences, [global corporations] are even more powerful and "unpredictable" than oligopolies confined to a single country' (Panić 2011: 143). This 'unpredictability' reveals the directionless character of transnational corporate capital as the subject of globality which in a financialized global economy cannot easily be contained within or subordinated to the culturally determined interests of territorial states.

Finally, we shall examine transnational neoliberalism as the ideology of corporate globalization that articulates the prerogative power of capital. Transnational neoliberalism has its origins in the accumulation crisis of the Keynesian national welfare state and the deregulation of finance capital in the 1980s. Anticipating the discussion in Chapter 5, we assess the extent to which transnational neoliberalism is consistent with the national interest of the advanced economies of the West where debt, monetary instability and 
negative demographic trends are reducing the capacity of governments to create growth. This breach in the growth-oriented logic of Western capitalism is already corrosive for Western economies, causing social fracture and political instability as inequality and oligarchy triumph on the ruins of social democracy. While globalization has increased GDP per capita among the global elite and among the new middle classes of India and China (Milanovic 2012), it has done so by freeing global capital from dependence on the traditional matrix of consumerism in Western economies (Westra 2010). This reflects the proletarianization the Western middle class as an exhausted social force in low-growth, deflation-prone economies of America and Europe that are dependent on bank-created private debt to sustain mass consumption.

\section{The logic of corporate power}

Veblen argued that the logic of corporate power lies in the capacity of the capitalist to 'block the industrial process at some one or more points. His strategy is commonly directed against other business interests and his ends are commonly accomplished by the help of some form of pecuniary coercion' (Veblen 1904: 21). Corporate rivalry, he added, is a 'struggle between rival businessmen and more often than not the outcome of the struggle depends on which side can inflict or endure greater pecuniary damage' (ibid.). Our primary question, however, is not whether markets are 'free' - as Žižek (2010) observes, the myth of free trade smoothes over the reality of persistent market failure - but why we have corporations rather than markets in the first place (cf. Bodie 2012). One answer lies in the nature of corporate organization as a mode of power founded on the principle of institutionalized advantage: in corporate social discourse - at least since Coase's (1937) theory of the firm - corporations operate outside market structures because the costs of maintaining market share and control over commodities and markets are too high if exposed to competition. In practice, it is too expensive for firms to operate in a free market for labour-power because commercial profitability is linked to investments in specialized human capital secured and defended by inculcating loyalty and conformity in return for legal guarantees of employment. The corporate workplace is a 'totally administered system' where unequal wealth is 'translated into naked institutional and social power' (Boggs 2011b: 26).

The status of corporate power in a global economy raises questions about the prerogative right and the legal accountability of capital, yet the logic of corporate power is poorly understood - despite the efforts of writers like Bakan (2002), whose exposure of corporate psychopathology in The Corporation was adapted into an eponymous film revealing the hollowness of corporate social responsibility in American media discourse. Addressing the systemic corruption of the US political and legal system by corporations, Bakan notes that the myth of corporate legal personhood exists to protect those who 'own and run large corporations from legal liability, leaving the 
corporation, a "person" with psychopathic contempt for legal constructs, the main target of criminal prosecution' (Bakan 2002: 79). The decision on whether to comply with law is, he adds, a 'matter of costs and benefits', for even where costs of non-compliance are substantial, these are factored into the normal accounting strategies of managers and lawyers.

However, while this type of critical investigative approach is valid, it fails to provide an adequate theoretical framework for explaining how capitalist sovereignty is articulated through the objective economic domination of the corporate business form. To achieve this we must understand that corporate social organization is the most effective means devised for accumulating and concentrating capital and for advancing the range and complexity of human economic activity through extended systems of logistics, extraction and financial control. Corporate hegemony is not a pathology or 'unintended consequence' of capitalism, but the logical institutional form assumed by capital to overcome natural, legal and moral constraints which impede the valorization of value in the reproduction of capitalist social relations. Impersonal and combined ownership allows corporations to withhold valued resources from social use, restricting the industrious/creative capacity of society while co-opting or incorporating counterhegemonic initiatives to promote non-corporate organizational forms (Bruno \& Karliner 2002).

Since the nineteenth century the corporation has acquired the legal status of personhood in US law - a legal fiction that has become a norm of international business law. In US law, argues Ransel, corporations held no rights as such, only "privileges granted them by the people of their chartering states, because there are only two parties to the Constitution, the people, who are sovereign and have constitutional rights, and the government, which is accountable to the people, and has duties it must perform to their satisfaction' (Ransel 2009: 1). The acquisition of legal personhood was made possible because 'corporations are a creation of government, and government must perform to the satisfaction of the people'. As a result, they 'would have to discontinue being a creation of government - which serves the people - and, in effect, become people, entitled to the rights of the sovereign under the Constitution, if wealthy corporate shareholders were to continue minority rule' (ibid.).

Nace (2003) locates three stages in the consolidation of corporate rights in US law and subsequently international law: first, corporations benefited from the legislative creation of quasi-rights, yet remained constrained by charters regulating their size and longevity, extent of ownership, geographical scope, liabilities and profits; second, corporations successfully challenged legal restrictions on their freedom to act through judicial admission of corporate constitutional rights; third, corporations gained global rights through the negotiation of international trade agreements which enable business to operate with a minimum of legal and financial constraint in multiple jurisdictions by universalizing from particular legal and financial norms operative in their countries of origin. 
It is in the US that corporations first acquired political power not simply by eliminating legal constraints on their growth and influence over government policy but by actively defining the structure and substance of American society as the ontological ground for the self-valorization of capital. Corporate power also emerged as a primary determinant of the socialization of labour for the normative and substantive reproduction of consumer culture. In the 1890s intensive competition, weak demand, organized labour and overcapacity all conspired to produce deflation and reduce profits, with the result that capital's share of income declined as the cost of new fixed capital (machinery) and variable capital (labour) rose. This fuelled an accumulation crisis characterized by 'bloated inventories, feverish competition, and more business closures as simultaneously rising interest rates entice[d] capital away from productive to speculative endeavours' (Westra 2010: 32). Exiting this crisis called not only for changes to statute at state and federal levels and the disciplining of labour, but the cultivation of a new class consciousness among corporate elites, and the transcendence of traditional petty bourgeois hostility to corporate power fuelled by a populist preference among industrial workers and artisans for the political economy of republicanism (dispersed assets/ competitive markets/autonomous labour-power). With the intensification of class conflict, American society faced a 'stalemate', and the crisis of 1896-97 demonstrated in stark terms that 'the social foundation of economic growth was the central and unavoidable issue of American politics' (Livingston 1986: 54).

Yet the depression of the 1890s facilitated a major structural adjustment of the US economy and validated the corporate critique of "unfettered competition among entrepreneurs whose enterprise was "excessive", "wasteful" and "ruinous" because it produced a volume of commodities that overran remunerative demand, reduced prices and profits, and transferred income from capital to labor' (Livingston 1986: 54-55). This period of US history is popularly known as the 'Progressive Era', but as Kolko (1964) argues, it was less a triumph for middle-class opponents of corporate power than a victory for conservative capitalist interests who favoured federal regulation to reduce competition and stabilize profits (cf. Weinstein 1969). The corporate rationalization of US society was achieved at the expense of smaller propertied interests, who, albeit formally equal subjects under US law, could not compete with corporations at an interstate level. The Progressive Era effectively reduced intercapitalist competition and the dependence of capital on skilled labour (Saros 2009). It also led to the privatization of monetary policy in the US with the founding of the Federal Reserve in 1913, completing the transition from self-regulating market libertarianism to political capitalism, while transferring the right to create new currency to financiers (Livingston 1986: 229).

Thompson notes the significance of oligopoly for entrepreneurial capitalism in that the "most likely candidates for entry into corporate dominated markets are other giant enterprises having requisite financial and organizational resources, and looking for ventures with above normal expected profitability' (Thompson 1974: 6). In the corporate state, he adds, competition 'resembles a 
contest among giant enterprises for consumer patronage and loyalty than it does an impersonal struggle of nameless firms against omnipotent market forces' (ibid.). The corporate social form offers a practicable combination of conflictual and hierarchical value orientations that is inconsistent with the ideal of inter-firm competition in market libertarianism. This model of business organization based on large vertically integrated multiunit enterprises quickly superseded the decadent social form of family enterprise established under British hegemony. Against the backdrop of the Depression, the corporate model was supported by Federal government policies to stimulate aggregate demand and new measures to promote full employment - primarily within the corporate sector, which by the 1940s accounted for more than four-fifths of US GDP (Arrighi et al. 1999a). After 1945 the corporate model was adopted on a global scale, reflecting the rise of the US to global hegemony, although as the "ranks of multinational corporations were swollen by these new arrivals, a global system of production, exchange and accumulation came into existence that was subject to no state authority and had the power to subject to its own "laws" even the most powerful states, the United States included' (ibid: 146).

Yet, while historians view organizational innovation as the principal independent variable for explaining the success of corporate capitalism, it is clear corporate organization - like the culture it organizes - instantiates the sovereign constitutive logic of capital in its postliberal transnational form. That is to say, structural features of capitalist organization (global division of labour, rules-based trade, etc.) do not come into existence independently of the capital relation, but are determined by changes in the value form-determined character of production organized through global networks of corporate power. Perrow protests that academic discussions of corporatism fail to 'take into account any of the many characteristics of organizations that shape society' (Perrow 2002: 11), but organization itself cannot be abstracted as a causal variable from the objective socioeconomic conditions of capitalism which necessitate changes in the legal and technical regulation of ownership and control. Perrow is correct to argue that under corporate capitalism large-scale organization is a necessary condition to maintain the concentration of power required for the reproduction of capitalist class domination; yet it is capitalist relations rather than formal organization that predetermines the rationalization of social norms and political-organizational practices in corporatism, a process which seems certain to accelerate as alienated labour is divested of socially productive powers and society is further weakened by a cognitive deficit of understanding (lack of global perspective) and a societal deficit of solidarity (social alienation).

The prerogative power of corporate social organization reveals the correlation between capitalist sovereignty (capital as subject) and legal right expressed in the fiction of legal personhood. From a Marxian perspective law is not a neutral body of codified norms but a juridical condensation of past conflicts of interests enforced by the threat of coercion - a social 'truce' expressing the 
balance of social power at given historical junctures. In the corporate state 'law is the site of open and avowed political conflict that undermines even the fiction of community, a conflict that brings to the fore the relation of power and privilege already (and necessarily) inscribed in law' (Dean 2009: 14). It is not enough to reduce law to ideology, however, for this would be to rehearse an economistic fallacy. Searching for the deeper roots of law in the economic relations of capitalist society, Pashukanis (1924) observed that bourgeois right articulates ideological precepts, yet a more fundamental correlation exists between capitalist exchange and the idea of legal personality embodied in sovereign individuals (corporations) as 'bearers of rights'. In capitalism all production is for exchange and production takes place on the basis of exchange:

The form of law - with its aspect of a subjective investiture with rights is born in a society which contains isolated possessors of private egoistic interests. When the entire economic life is built upon the principle of the accord of independent wills, then - as if reflected in a mirror - every sort of social function takes on a legal character - that is to say, it becomes more than a social function: it becomes also the right of the person who is carrying out that function. However, since private interests cannot attain such complete development and such overwhelming significance in a political organization (by its very essence) as in the economy of a bourgeois society, so subjective public rights also come out as something ephemeral and without genuine roots, and are constantly subjected to doubt.

(Pashukanis 1924: 155)

Right is derived from commodity-determined relations: the commodity is the 'private property of its owner, given in return for the commodity owned by the other. Each agent in the exchange must be an owner of private property, and formally equal to the other agent(s). Otherwise what occurred would not be commodity exchange' (Miéville 2004: 282). For Pashukanis, this is a conflictual process, for it is axiomatic that between equal rights force must decide. In an intra- and interstate context, bourgeois right expresses the contradictory 'opposition and equality' of equal legal subjects, for where conflicts of interest arise between formally equal individuals through exchange then a certain type of regulation is required. This must 'formalize the method of settlement of any such dispute without diminishing either party's sovereignty or equality. That form is law, which is abstract, based on the equality of its subjects and pervasive in capitalism' (ibid.). In effect, the 'equality of distinct and different individuals is in exact homology with the equalization of qualitatively different commodities in commodity exchange [...] Thus with the generalizing of legal relations, "legal fetishism complements commodity fetishism"” (ibid.: 284).

Pashukanis was executed in the Great Terror and his work discredited by Soviet ideologists charged with codifying 'socialist legality' as a new juridical 
model of social regulation in the USSR and - after 1945 - in Eastern Europe. Pashukanis became an 'unperson' because he refused to acknowledge the transhistorical element of legality as a prior condition for social order which no political system - not even fascism - can dispense with entirely (Neumann 1942).

Yet the point of this excursion into Marxian legal theory is not to highlight the link between the commodity form and the legal form, but to indicate the relevance of capital-logic approaches for understanding the state form of transnational capital. As Miéville observes, Pashukanis's real theoretical error was not that he jettisoned the bourgeois notion of rule of law in its totality (thereby denying any transhistorical value to the concept of rule of law), but that in attempting to derive a coercive abstract state as a guarantor of legal relations in capitalist society, he failed to notice that coercion is always already implicit in the structure of the commodity form itself as the organizing principle of capitalism. Pashukanis theorized coercion as an 'imperative addressed by one person to another', backed up by a transcendent force (the state); yet the principle of contestation is implicit in the very form of the commodity, which is to say, in the sense that private ownership of commodities constitutes a logic of exclusion. Yet violence is at the "heart of the commodity form. For a commodity to be meaningfully "mine-not-yours" - which is, after all, central to the fact that it is a commodity that will be exchanged - some forceful capabilities must be implied' (Miéville 2004: 287). Violence is integral to all historical formations structured through commodity exchange, and this feature of the capital relation is extended and intensified by the corporate reorganization of capitalism, the advent of permanent war readiness and the institutionalization of differential accumulation as a precondition for oligopoly.

This is not a deviation from the 'correct' course of capitalism, for the corporatization of US society and the globalization of corporate power are logically entailed in the commodity form itself - and, by extension, in the legal and political structures derived from it. Capitalist sovereignty (the actualization of capital as the subject of modernity) is realized only through recognition of corporate legal personhood as a precondition for legal non-liability and political unaccountability - which (like states, but unlike non-corporate persons) have a potentially infinite lifespan enabling them to accumulate power indefinitely. In this sense, corporate personhood intensifies in a radical and totalizing way the commodity-determined logic of exclusion in the doctrine of bourgeois right - signalling the de facto supersession of private right over public law in the constitution of global capitalism.

Thus the specific question that presents itself is how dominant capital secures its prerogative power as the subject of global capitalism, and what the consequences of this are for Western power in general and US hegemony in particular. For some, the fusion of corporate-state power in neoliberalism indicates the absence of contradiction between economic domination and imperial state authority: the latter is simply conceptualized as a function of 
the former, and it is through globalization that the hard power of the US military has become an instrument for consolidating Western economic interests (Petras 2005). Yet for others the fusion of state and corporate power heralds the decline of Western hegemony as Anglo-American capital struggles to prosper at the expense of its own labour force, leading to inequality, precarious employment and the disappearance of 'middle-class' (skilled) employment (Lazonick 2013; Lipietz 2001).

Following Duménil and Lévy (2001; cf. Kotz 2007), Westra notes that corporatism entailed four stage-specific transformations in the structure of capital accumulation, namely: (i) a radical separation of ownership and management (the technostructure); (ii) a tendency towards integration (intrafirm transactions) and shaping of demand to guarantee commercial viability of consumer goods (termination of market economy); (iii) offsetting of high fixed costs of consumer durable production through new product lines and geospatial expansion; and (iv) a union of finance between banking and industry to provide credit to support consumer demand for expensive items like automobiles and houses (Westra 2010: 80). The corporate model achieved temporary stability through demand management, generous welfare and private debt, but as we shall see in Chapter 5, it merely delayed an accumulation crisis which has destroyed the class compromise of Fordism. The result is 'neoliberalism', which has brought to a head a 'multiplex process that would cement both the abdication of the state from support for consumerist capital accumulation and fundamentally accelerate the reshaping of material economic life primarily in the US, though increasingly across the globe' (Westra 2010: 116).

Corporate globalization implies not simply a flight of finance capital to low-wage economies or the dependence of Western non-financial corporations on financial assets (Cox 2013), but the declining coherence of advanced nations as capital degrades the infrastructural basis of industrial society in a 'race to the bottom' to coerce American and European workers to compete with low-wage earners in Asia and Latin America. For critics like Boggs (2011a), Wolin (2010) and Cox $(2012,2013)$, the subordination of US foreign policy to the interests of capital indicates the increasing control of the US and global economy by a system-integrating transnational bloc. The largest corporations, argues Cox, have increased

global market share across a range of industries from the 1980s to the present, a trend which is closely linked to the growing importance of global value chains. Such chains link a highly competitive world of small and medium-sized business entrepreneurs at the bottom of the chain with corporations at the top who are increasingly able to act as 'system integrators' that set the terms for increasing complex global production networks $[\ldots]$ In the contemporary global supply chains most large-scale global corporations no longer produce a product from start to finish, but instead use their position at the top of the global supply chain to set the 
terms for doing business with thousands of potential suppliers, who are engaged in fierce competition to be included in these global production networks.

(Cox 2012: 13-14; cf. Cowling \& Tomlinson 2005)

The result is an increasingly decentred global economy that articulates corporate power through the institutionalization of differential accumulation in a global network of value chains that facilitate a periodic return to profitable investment ('business as usual') through cycles of overaccumulation followed by a managed destruction of wealth in regimes of 'anti-production' characterized by financialization, recession and war. The trigger for financialization was market liberalization in the 1980s, an attempt to correct historically high levels of inflation inherited from the 1960s and the end of the New Deal (Kawamura 2013: 39). Global corporations, financial and non-financial, have grown to depend on the financialization of leveraged profits to compensate for falling rates of profit experienced by even globally competitive firms in the 1970 s (Cox 2012), but banks in particular have extended the limits of discretionary lending to integrate broader sections of the working class into the credit/debt nexus of capital - accelerating the global financial crisis when hundreds of thousands of US mortgage holders defaulted in 2007. Rather than protect borrowers, regulatory policies have tended to shield 'system-relevant' institutions from the effects of financialization, underlining the 'institutionalized relationship between financial capital and the US state that is the product of a long-term transformation in global capitalism [...] responsible for a widening gap between rich and poor - in the US and globally' (ibid.: 14). The subsequent transfer of corporate debt to the public increased the power of the banking sector which effectively exploited the financial crisis to effect a leveraged buy-out of the US economy (Ivry 2014), while extending opportunities for speculation in peripheral economies as emerging markets seek to develop their own capital markets and regional structures of financial integration independent of Western control.

\section{Dominant capital and corporate agency}

As Nitzan and Bichler (2009: 251) argue, the modern corporation 'emerged not to enable large-scale industry, but rather to prevent it from becoming "excessively" productive'. Following Veblen, they suggest that the growth of capitalist competition after the Civil War led to a massive growth in productivity to satisfy rising demand, and that if this "pattern of competitive production were to continue, industry would tend to generate much more output than could be profitably sold, bringing pricing down and business enterprise to a halt' (ibid.: 252). The rise of the corporation in the US was a response to the need to reduce competition and curb overproduction by reducing the number of small businesses through vertical and horizontal consolidation. In the 1890 s, they observe, the US witnessed a 
widespread incorporation of business firms, the rapid growth of stock and bond markets and the expanding use of credit as a form of ownership. It was during that period that the separation of business from industry was finally completed. Firms were turned into corporations and investors into absentee owners of discounted future earnings. From then on, the predicament of excess capacity remained a more or less permanent feature of US capitalism.

(Nitzan \& Bichler 2009: 252)

Consolidation was facilitated by mergers and acquisitions which meant that companies required a quantitative pecuniary value: in effect, capital had to become 'vendible', stimulating the development of capital markets as a means to drive the growth of equity while retarding 'excessive' competition and productivity growth. From this perspective, dominant capital thrives only by limiting competition and restricting the industrious activity of society for its own gain through mergers and acquisitions which generate the power to increase earnings, set market prices and reduce risk. The maturity of capital as a mode of power correlates with the variable level of sabotage which can legally be inflicted on communities, because the corporation - like a bellicose state - can only increase relative gain through the production of uncertainty, instability and dissonance: 'It is only by propelling industry in ways that interfere with and partly hamper its open integration, coordination and the well-being of its participants that business earnings can be appropriated and capital accumulated' (Nitzan \& Bichler 2009: 227, 256-58). Corporate power is also conditional on the capacity of corporations to sustain monopolistic/ oligopolistic market conditions over time in partnership with the state: serious capital accumulation 'is only possible when one firm or a small group of firms has a quasi-monopoly of world-economy-wide production [...] We call such quasi-monopolies leading industries, and they foster considerable forward and backward linkages' (Wallerstein 2011b: 1).

The primary issue here is not the economic power that inheres in the mere act of controlling resources, but the ways in which absentee ownership and the institutionalization of social exclusion deny economic power to a majority of citizens - a point Marx recognized in his analysis of the composition of total social capital. ${ }^{2}$ In contrast with Marx, however - who was more concerned with defining the substance of capital - Veblen (1923) approached capital as a pecuniary value based on its capacity to incapacitate society: the corporate organization of the US in the early twentieth century led to the institutionalization and political legitimation of 'strategic sabotage' as a basis for realizing pecuniary value - that is, the pecuniary capitalization of earning power which depends less on capacity to produce than on capacity to incapacitate:

With the twin emergence of the modern corporation and the modern state, capitalism has acquired a 'civilized' face: absentee ownership has 
become a legitimate norm; open violence has been replaced by latent threats underwritten by hefty advertising budgets, bloated security services and overflowing jails; and power has solidified into a mystical structure (at least for those subjected to it). In this new order, the power to incapacitate - or sabotage, as Veblen liked to call it - becomes a fully legitimate convention, carried out routinely and invisibly through the very subordination of industry to business. The blueprints of capitalist production are already programmed for business limitation [...] In order to merely earn the normal rate of return, all the owner has to do is own.

(Nitzan \& Bichler 2009: 232, emphasis added)

Although Nitzan and Bichler insist that strategic incapacitation is a common feature of all systems of hierarchical production that exist at the expense of (rather than in the service of) their constituent populations, it is clear this model of order reached its zenith with corporate capitalism, which thrives not on efficiency but market power - the power to determine the extent (or existence) of competition and hence the power to set prices and establish control of markets: value is created not by promoting maximum growth, but by sustaining differential earnings. If maximizing efficiency and growth were the real aims of business, then differential accumulation would be impossible and business would be susceptible to unmanageable uncertainty and risk. In such conditions capital could not be sovereign; on the contrary, sovereignty would pass to workers/consumers, who would acquire the leverage to force corporations to make and sell socially useful low-cost goods or go out of business. To demonstrate this, Nitzan and Bichler (2009: 237-38) plot a time series measuring profitability against unemployment, revealing the disutility of full employment for maintaining differential rates of return by corporations: 'Business as usual' (the necessary level of strategic limitation imposed on industrious communities) is defined as a median point between the extremes of maximum sabotage (complete incapacity) and minimum sabotage (full capacity leading to overproduction and loss of earnings). For this reason, the persistence of recession is not in and of itself an issue for dominant capital, only its capacity to 'beat the average' rate of return in a relative sense. Although most mainstream economists insist that income share of capital and unemployment should be negatively correlated, in the US the correlation is positive, rising in downturns and falling in upswings. This was the case in the 1930 s, and is the case now as the income share of the top 1 per cent rises due to upward redistribution amid general economic stagnation and rising poverty (Nitzan \& Bichler 2014).

The search for above-normal returns is the conditio sine qua non of capitalist power based not simply on the ability of corporations to increase and maintain profit rates relative to their rivals, but on the capacity of dominant capital as a power bloc to restrict average rates of return in the wider economy and prevent effective government protection of public enterprises. The means for achieving this outcome are extensive, including 'direct limitations' 
(predatory pricing, etc.), and indirect strategies such as 'patent and copyright laws, industrial policies, financial regulations, preferential tax treatment, legal monopolies, labour legislation, trade and investment pacts and barriers and, of course, the use of force, including military, for differential business ends' (Nitzan \& Bichler 2014: 247). The limitation of democracy in the corporate state follows similar principles: to reduce levels of political unmanageability and risk, corporate-state elites routinely limit civil liberties and reduce executive accountability to legislative and judicial institutions. In this way, the constituent power of subjects (popular sovereignty) and the mediating role of their representatives are both overwhelmed by the constituted prerogative power of the state which responds to the private lobbying power of vested interests, extending and intensifying the relations of domination and elite rule (Domhoff 2014). ${ }^{3}$

The capital relation is the determining factor in differential accumulation because capital itself is power: the aim of corporate capitalism is not production but control over production through complex global networks of extraction, production and supply in competition with other transnational concerns (brands) which generate similarly above-average rates of profit. It was declining profitability in the non-financial corporate sector that drove globalization, leading US corporations to draw on the power of government to advance the interests of transnational investors by 'enacting trade and investment agreements that provided legal, institutional and political support for the expansion of global supply networks' (Cox 2012: 13).

This phenomenon is still visible in the pressure applied by corporate lobbyists on the US government and the EU Commission to ratify the new TTIP. When the secret text of the proposed agreement was leaked in March 2014, it became clear that its purpose was not free trade but to institute a new 'investor-state dispute settlement' (ISDS) which will allow private corporations to sue national governments if they consider that legislation has negatively harmed their legal 'rights' - for example, by blocking corporate investment in public services. The aim of ISDS is to depoliticize disputes between transnational investors and public authorities over a range of issues from environmental and consumer protection to public health and education. Although discussions on TTIP have largely been ignored by corporate media, if successful the agreement will establish an important precedent, enforcing the logic of privatization and making it 'financially ruinous for EU countries or the US to introduce any legislation which was not in the interests of corporations' (Dunt 2014: 3).

The machinic structure of corporate capitalism creates order by projecting the social power of capital onto an infinite horizon until it acquires a level of facticity that ensures its own dynamic self-reproduction as further forms of power are rendered quantifiable and open to augmentation by harnessing the creative and innovative capacity of human communities, or through the institutionalization of permanent and unpayable indebtedness. The 'crucial group' in this machinic order is dominant capital, comprising corporate- 
governmental coalitions. By contrast, the 'periphery' of capital is a permanent threat to differential accumulation: by providing competition, small enterprises

undermine the collusive underpinnings of business 'sabotage' and therefore the very possibility of accumulation. It is only to the extent that dominant capital can retain and augment its exclusive power against these lesser capitals [...] that the capitalization process can be sustained and extended.

(Nitzan \& Bichler 2009: 315)

Corporate sovereignty thus constitutes an exceptional form of capitalist power which Deleuze and Guattari defined as machinic enslavement - an 'apparatus of capture' that arises where 'human beings themselves are constituent pieces of a machine that they compose among themselves and with other things $[\ldots]$ under the control and direction of a higher unity' (Deleuze \& Guattari 2004a: 457). This higher unity is capital - a mediated global totality in which relations of power unfold logically from a single structuring principle - the valorization of value. In neoliberal disciplinary capitalism, however, this structure of machinic enslavement produces more subtle forms of subjectivation through the allocation of complex identities and roles supportive of the credit-debt nexus which 'constitutes the human being as subject linked to a now exterior object, which can be an animal, tool, or machine. The human being is no longer a component of the machine but a worker, a user' (ibid.). Subtle modes of subjectivation thus reconstruct the totality; their integration in the structure of alienation is produced through conformity, buoyed by the corporate culture industry as an ancillary structure of political socialization which disseminates a complex array of private rewards and dividends that anaesthetize and immobilize public opinion.

Separation of ownership and control, restriction of competition and reproduction of dominant capital through differential accumulation and the interpellation of subjects reinforce the power of corporate elites which constitute the human personification of capitalist subjectivity. As Marx argued:

As the conscious bearer of this movement [of capital] the possessor of money becomes a capitalist [...] The objective content of the circulation we have been discussing - the valorization of value - is his subjective purpose, and it is only in so far as the appropriation of ever more wealth in the abstract is the sole driving force behind his operation that he functions as a capitalist, i.e. as capital personified and endowed with consciousness and a will.

(Marx 1859: 254)

If capital is understood as the subject of modernity, then to explain corporate agency it becomes necessary to examine more closely the interests of the 
various contenders for control, the information that is available to them, the conditions under which each may enter the dominant coalition, and the consequences for corporate behaviour that follow from the particular composition of the coalition' (Scott 1997: 43). Where impersonal possession becomes the norm, argues Scott, 'control is structured through corporate and institutional shareholdings, but corporate rule is exercised by the individual agents who represent the shareholders and financiers [...] The corporate strategy that is formulated by corporate rulers is the outcome of their struggle to determine corporate behaviour' (ibid.).

Corporate agency is a characteristic feature of all capitalist economies, but the hegemonic core of Anglo-American financial capital is constituted in 'constellations of interests' - intercorporate shareholdings which form structures of impersonal possession that are controlled by dominant coalitions of directors and investors. The core of Anglo-American dominant capital is formed by constellations of financial interests, financial intermediaries that operate through interlocking networks of directorships and inter-investment, maintaining strategic control over the long-term direction and management of financial and non-financial businesses. These constellations can be compared broadly with similar structures of ownership and control in other capitalist systems, including 'corporate filiations' in Germany (enterprises with overlapping vertical filiations), and 'alliance capitalism' in Japan, but in a general sense it is the balance between corporate blocs 'that defines the characteristics of the major forms of capitalist development and their particular structures of impersonal possession' (Scott 1997: 52).

Scott also observes the relative impact of variant forms of impersonal possession on corporate agency, and notes critically that academic 'discussions of corporate strategy have often taken a rather simplistic view of markets, seeing enterprise behaviour in terms of the interaction of supply and demand. Very little attention has been given to the role of "non-market" factors in structuring commercial relations' (Scott 1997: 204). Non-market structures come into being or increase in power where advantages for accumulation outweigh the cost of their maintenance. Yet there is a reluctance in liberal economic theory to acknowledge both the extent to which corporate agency is determined by motives of power rather than productivity, and the weakness of ordinary shareholders in constraining the actions of major institutional shareholders and corporate directors through effective corporate governance. Echoing Simon (1945), Scott concludes that in the real world, corporations 'formulate strategies on the basis of their knowledge of the economic environment as they perceive it [...] Business leaders can never be sure that they have chosen the optimal course of action' (Scott 1997: 218-19). This creates a tendency towards 'satisficing', leading to a 'search for those courses of action that will generate sufficient profits for them to survive over the long-term' (ibid.: 219).

Recent studies of corporate power challenge the neoliberal 'corporate governance doctrine' in IPE which overstates the democratizing effect of 
shareholder activism on corporate agency, rationalizing the failure of shareholders to exert control as a result of inadequate governance strategies. As Soederberg (2010: 12) argues, it is only by acknowledging the "material conditions of our social existence that we can understand more fully the paradoxes, the nature of power and the politics of domination and resistance inherent in the corporate governance doctrine'. To achieve this, she argues, we must accept four premises, namely: (i) that the corporation is a social relation of capitalism rather than an autonomous entity (and that the evolution of corporate power as a vehicle for capital accumulation is inextricably tied to the contradictory logic of capitalist societies); (ii) that existing studies fail to emphasize the historical importance of credit as a condition for accumulation in capitalist economies where personal liability has been replaced by legal non-liability; (iii) that the growing power of institutional investors has led to greater economic interdependence between publicly traded corporations and social security capital ('labour's capital'), which has in turn increased incentives for workers to accept the status quo by linking their savings to the performance of corporate actors; and (iv) that the capitalist state continues to play a major role in depoliticizing the contradictions of private ownership through neoliberal market ideology (ibid.: 16; cf. Holloway \& Picciotto 1978; Dean 2009).

Yet the role of the corporate state is also to manage overaccumulation and the declining rate of profit. In periods of prosperity, capital accumulation assumes 'a relatively constant composition, absorbing progressively larger numbers of workers into the production process' (Itoh 1988: 301), but as Westra (2010: 32) argues, rapid accumulation spurs a new period of 'precipitancy which reveals the existence of a superabundance or overaccumulation of capital in relation to the size of the working population'. Once rising wages reduce profit, the economy is propelled into crisis as businesses close and interest rates 'entice capital away from productive to speculative endeavours' (ibid.). At this point the state typically assumes an extraordinary function of demand management, and as we shall see in Chapter 5, intensive accumulation based on extraction of relative surplusvalue does not destroy the labour force (as in the case of absolute surplusvalue), but operates by tendentially expelling variable capital (labour-power) from production, which in turn leads to an increase in the organic composition of capital (technology, fixed capital, etc.) and a decline in the general rate of profit. For some Marxists this constitutes a general economic 'law'; for others, it is an economic expression of class struggle. In expansionary moments of the cycle, however, overaccumulation is typically accompanied by an increase in speculative trade and credit growth, creating inflationary debt bubbles and the eventual collapse of commodity and equity markets as investors sell off devalued assets ahead of market corrections.

Bracketing for the present the distinction between excess-commodity and excess-capital approaches to declining profitability, we may agree with Itoh, who notes that the inner contradictions of capital 'appear most obviously in 
those periodical self-destructive crises, in the process of business cycles' (Itoh 1988: 290). Overaccumulation reveals the dynamic quality but also the potential inner limits of capital in its present phase: this tendency takes the form of rivalry between concentrations of capital for control over material and human resources, leading to a contradiction where on the one hand corporations seek to increase profits by expanding productive capacity beyond the natural limit of the market (while sustaining a necessary quantity of 'lack' by failing to satisfy elementary social needs), yet on the other hand seek to reduce economic activity at the cost of destroying the productive capacity of society and creating unemployment. It is corporate financial capital that brings the modern state form of capital into being as an active economic actor which 'contributes to retarding the fall of the rate of profit of private capital or even to compensating for it in crises by a policy of "socialization of losses" (Altvater \& Hoffmann 1990: 147). There is no alternative to this fiduciary system because corporate capital requires the state to overcome an irresolvable antagonism between production for private profit and underconsumption by absorbing into itself the mass of surplus-value that cannot be realized and invested profitably. At the point of downturn, which Marx termed the absolute overaccumulation of capital, no additional investment of capital produces any increase in surplus-value, which therefore goes into precipitate decline. When this occurs, further profitability depends on the capacity of capital to purchase labour-power below its actual market value by sustaining conditions of dependency, undermining the productive capacity of society and the possibility of consumption either by diverting capital into militarized accumulation to absorb excess capacity (fascism), or by ransacking public budgets through austerity programmes which sabotage the livelihoods of productive and unproductive citizens (neoliberalism). The cyclical onset of recession signals the return of a bear market that re-establishes conditions for valorization, enabling corporate-state elites to restructure the political economy of capitalist power within and between regimes of accumulation. Paradoxically, therefore, capitalism tends towards the securitization and authoritarian re-regulation of society at a global level, reasserting the power of the state form of capital as the 'concentrated force of free economy' (Bonefeld 2013).

\section{Transnational neoliberalism}

Three approaches have been developed in international political economy to explain the occurrence of neoliberal hegemony, namely state power relations theory, the theory of the transnational capitalist class and the theory of privatized authority (Plehwe et al. 2006). The first examines neoliberal hegemony as a function of US state hegemony and has been advanced primarily by neorealists who do not - as Plehwe argues - appear to have noticed that neoliberalism was gaining support before the US economy went into decline in the 1970s, and certainly before the dramatic reassertion to US economic 
and military power in the 1980s which destroyed détente and accelerated the collapse of the Soviet Union (Halliday 1986). The second approach, associated with the Amsterdam School (Overbeek \& Van der Pijl 1993; cf. Sklair 2001; Bieler \& Morton 2006; Carroll 2010), stresses the ideological links between neoliberalism and transnational corporate power, focusing on the rise of a global investor class with interests distinct from those of national capitals. Transversing this perspective, a third approach stresses the influence of transnational private authorities in global economic governance - specifically those agencies engaged in the advancement of neoliberalism. The category 'private authority' is pluralistic, and includes not just corporations but also advocacy networks, think tanks and international nongovernmental organizations (NGOs) that influence policy at national, regional and global levels (Stone 2000; Taylor 2010). Supporters of this view argue that despite potentially overstating the relevance of transnational non-state actors, it grounds a transnational civil society perspective which 'provides us with crucial insights into the contribution of a wide range of civil society forces in the transformation of order and hegemonic constellations' (Plehwe et al. 2006: 16).

Neoliberalism must properly be understood as a hegemonic class project of the transnational right aimed at reasserting capitalist sovereignty through the consolidation of corporate hegemony. Capitalist sovereignty is formally instantiated only through the establishment of corporate personhood as a precondition for legal non-liability which intensifies the form-determined logic of exclusion entailed in the doctrine of bourgeois right. Globalization in turn signals the instantiation of bourgeois right at a transnational level incorporating the anarchic geopolitical logic of international relations into the geoeconomic logic of corporate power. In its original form, argues Dean, neoliberalism had a 'critical purchase', but has since evolved into such a 'catch-all term that it not only denies the empirical diversity of political rationalities and governmental techniques of contemporary societies but has [...] ended up legitimating the self-description of dominant power-formations and down-played their positively illiberal, authoritarian and despotic components' (Dean 2014: 70). Neoliberalism is neither a completed project nor unchallengeable reality, but a partial and always temporary resolution of contradictions in the organization of corporate power produced by uneven economic development and global 'free trade'. It is not a coherent political theory but a context-dependent discourse condensing market rationality, private power and international competition which builds upon existing economic forms and cultural practices while eroding embedded structures of national economic organization through the creation of competition states adapted to corporate globalization (Desai 2006; Cerny et al. 2005; Shaikh 2005). ${ }^{4}$

Considerations of space rule out an extended analysis of the intellectual origins of neoliberalism - a topic well covered in the literature (Menz et al. 2005; McVeigh 2005; Aidi 2009; Bedirhanoğlu 2008; Birch \& Tickell 2010; Smith et al. 2010; Dussel-Peters 2006; Bohler \& Neunhöffer 2006). The term 
'neoliberalism' has its origins in economic debates in the 1930s in the US, Germany and Britain between right-wing liberals keen to reinvigorate classical economic theory. In the 1940s, an international network of academics emerged centred on Friedrich Hayek, which sought to mobilize academic and political opinion against socialism. The network maintained a radical stance through an extended war of position rather than subscribe to 'feasible change' (Plehwe 2009: 6; cf. Birch \& Tickell 2010). Monetarist ideology was inserted in and rearticulated through nationally specific counterrevolutionary projects, most powerfully in the authoritarian-populism of the New Right in the US, Britain, Chile and Argentina, where experiments in neoliberal regime change were conducted (Harvey 2005; Miller 2010; Haslam 2005; Durham \& Power 2010), although paradoxically the emphasis on private authority advocates a rationality that 'appears in a fetishized form as neutral and devoid of politics' (Cutler 2011: 49).

For Cutler, neoliberalism is an economic regulatory regime specific to the international political economy of capitalist globalization - a mode of regulation 'exercised by corporations under the global investment regime [that] effectively freezes out democratic participation' (Cutler 2011: 51). Drawing on the ideology of desire in commodity-determined society, neoliberalism also 'seduces the individual to give himself or herself up to a definition of a consumer subject and object, promising pleasure, happiness, wealth and success' (Penttinen 2000: 218). This dogma of private citizenship and consumption reconstructs the Lockean ideal of the 'ownership society' founded on bourgeois right and non-interference, in which prudent citizens trade their loss of social rights for a "healthy economy coupled with a revival of the punitive nineteenth century language of moral failure, individual blame, the shame of "dependency", and the celebration of "personal responsibility" (Somers 1999: 123).

A key intellectual source of neoliberalism is Nozick (1974), who believed that exclusion was ultimately beneficial because while bourgeois right creates exclusion, it puts 'resources into the hands of those who can use them most efficiently and profitably' (Plant 2010: 101). It should be clear from the discussion in the previous section that this welfare effect is meaningless in the case of corporate capitalism, which is based on sabotaging the industrious creativity of communities (and rival independent producers) for the private pecuniary gain of dominant capital whose aim is long-term market domination rather than competition. The 'ownership society' of neoliberalism is legitimated via the ideology of free trade, yet the fiction of free trade between liberal democracies is really invoked 'to close down possibilities for the actualization of free trade and equality' (Dean 2009: 57). Furthermore the prescription for material acquisition and choice undermines civic duty and personal responsibility, illustrating the prescience of Max Weber's concern that cultural rationalization under capitalism would outstrip the capacity of individuals to act rationally and morally. As sociologists have demonstrated, ownership societies tend to foster an uncritical acceptance of presanctioned 
corporate identities, leading to a "neurotic immersion in and adherence to narrowly focused routines and systems of regimentation, measurement and control' (Bone 2010: 732; cf. Bauman 2002; Roberts \& Ng 2012; Offer 2006).

The ultimate political goal of transnational corporate power is the competition state as a response to the accumulation and legitimation crises of the 1970s, indicating three processes of change, namely: (i) movement towards a hypothetically borderless global economy and the expansion of global value chains and international portfolio capital flows; (ii) the institutionalization of neoclassical trade theory - articulated most forcefully in the logic of comparative advantage; and (iii) the transition from outcome-oriented interventionism to a competition state based on the privatization of collective assets, reduced corporate taxation and reduced welfare entitlements (Gamble 2006; cf. Leys 2008). Yet this competition state is not the creature portrayed in Western corporate media - a lean form of administration based on minimal intervention; it is, rather, a postliberal formation, signalling 'the ideological collapse of familiar verities of market relations, individualism, free choice and the comfortable equation of capitalism with democracy' (Boggs 2011a: 102). Corporate globalization is a response not only to the legitimation crisis of state-democratic capitalism (Habermas 1975), but a transnational reassertion of the general class interest of capital against gains made by labour, resulting in the deindustrialization of the capitalist core and increasing corporate investment in emerging market production via offshoring to create opportunities for a more 'refined' division of labour while exploiting technological changes that reduce costs and raise the efficiency of spatially dispersed supply chains. This reflects the oligopolistic power of transnational corporate networks which act as vehicles for the restructuring of capital markets and value chains in emerging market economies where suppliers must compete in asymmetric markets for contracts with 'lead firms' defined in technical economic jargon as 'oligopsony buyers in the market for inputs' (Milberg \& Winkler 2013). In more straightforward language, this indicates an asymmetric relation of power where a large number of local/regional producers compete for contracts with a small number of powerful corporations. Led by the US, argues Cox, the global restructuring of peripheral economies, has been supported by a nascent

transnational class within the developing world that was increasingly linked to global finance. In circumstances where these alliances were particularly strong, the greater the chances for the advancement and implementation of neoliberal policies favouring the establishment of global supply networks, by way of laws governing foreign direct investment and through expanded access to portfolio markets.

(Cox 2013: 13-14)

Intensive lobbying by transnational corporate-political networks has resulted not only in the growth of foreign access to capital markets in developing 
economies - formalized in regional trade agreements (RTAs), but in the formation of a transnationally oriented capitalist class which places its wealth offshore yet relies on strategic and financial statecraft by powerful governments in the West to leverage entry into new markets where the opportunities for corporate investment are greater than those in the depressed economies of the US, Europe and Japan. Although successful in North-East Asia (particularly South Korea), neoliberalism has been directly responsible for a restoration of asymmetric relations of power between core and peripheral economies which has undermined hopes for a 'New International Economic Order', leading to a reversal of 'priorities from developing production to securing profit and so subordinating the industrialization plans of the Third World to the discipline of capital' (Overbeek \& Van der Pij1 1993: 19). As Milberg and Winkler observe, this is reflected in the capacity of oligopolistic corporations to 'divide the production process into numerous steps and tiers [which] creates both a distance between lead firm rents and suppliers, and a greater ability to weaken labor bargaining power by creating more competition in segmented labor markets' (Milberg \& Winkler 2013: 126). This tilt towards capital has been formalized and extended through a reorientation of global governance from economic development to structural adjustment, reasserting debt as a lever of asymmetric power in the transnational political organization of capitalist sovereignty.

Transnational neoliberalism is supported by corporate-state elites in the West as a means for sustaining Anglo-American power, yet results in contradictory outcomes. As Gill observes, the expanding influence of financial corporate power in the 1990s reflects the determination of a transnational coalition of forces to enlarge its influence through an 'extension of the structural power of market discipline' (Gill 1993: 264). While the reorientation of the global economy towards financial deregulation and the erosion of national forms of capitalism were intended to reinvigorate US hegemony (and did so in the short term aided by the opening of opportunities for accumulation and development of new digital communications technologies which facilitate instantaneous transmission of market data between financial centres), the hypertrophied capitalism unleashed in the 1990s has led to a decline in US industrial power and unravelling of consumer society. Although not reflected in corporate media discourse, there is growing awareness in the US of the real human cost of financialization and offshoring which creates undeserving clear winners and losers as a result of shocks generated by the unrestrained movement of global capital (Freeman 2007).

The political function of neoliberalism is to replace state-democratic capitalism, co-opting popular classes and labour at a subordinate level within the transnational historic bloc, leading to a 'precarious hegemonic constellation' of embedded neoliberalism (Bohle 2006). As Reifer (2012) argues, rather than continue New Deal welfarist capitalism through progressive corporate taxation, US monetary policy 'ushered in its global demise' (Reifer 2012). The New Deal had subordinated private capital to public finance through 
Keynesianism, but neoliberalism made possible through the growth of global capital markets has led to a subordination of democratic public authority to capital, an increase in sovereign debt and the imposition of austerity, which have poisoned debates on welfare and equality as legitimate political issues. Whether the dismantling of US politics is an intended effect of globalization is an open question; the real issue is the distinction between globalization as the internationalization of capitalist relations of power based on the predatory search for new sources of accumulation, and globalism as a normative justification for the institutional complex of formal/informal transnational organizations that mediate between states, markets and non-state actors, through which the general class interest of transnational capital is articulated globally (cf. Panić 2011).

Cosmopolitans and internationalists who criticize the unaccountability of existing forms of global governance fail to note that the political origins of the state form of transnational capital lie not in internationalism but in the need for transnational corporations to augment extractive, productive and distributive operations, necessitating new forms of policy coordination where states converge voluntarily towards similar structures of administration and governance. Following Sassen (1999), Reifer traces the origins of this to the development of an international legal regime centred in the early twentieth century in the US and UK, created to manage the complexity of cross-border capital flows. Within this emerging system of capitalist power (contested by German fascism and other authoritarian capitalist states), international lawyers began to play an intermediary role in 'overlapping processes of warmaking, state-making and capital accumulation [... raising] funds on the money and capital markets for states and firms, along with engaging in more pure forms of financial speculation' (Reifer 2012: 32).

Unlike liberal capitalism, transnational neoliberalism requires not competition as a precondition for exchange but corporations with 'system relevance' in a financially integrated global economy without the autonomous producers, legal protections or civil liberties associated with embedded liberalism (Crouch 2011). Corporate capitalism, in this respect, is a 'rigged' politicaleconomic system that functions in the interests of dominant capital. Neoliberal corporate capitalism also places a higher value on primitive accumulation than productivity, removing entire sections of the manual and non-manual working class from 'traditional capitalist encasements' (Sassen 2011: 23), thus eroding the commodified form of labour-power itself (Westra 2010). Furthermore, neoliberal corporate capitalism flourishes in a postliberal managerialist environment founded on the privatization and instrumentalization of capital and technical expertise, transforming societies into 'laboratories' for refining the means of extraction and accumulation while eroding legal restraints on surveillance and control (Suarez-Villa 2010: 10).

Classical sociologists (Berle \& Means 1933; Rizzi 1939; Burnham 1941; Djilas 1957) defined this managerialist deformation of market society as a shift away from liberal capitalism, placing theoretical emphasis on the power 
of managers over the social surplus and the formation of a managerial 'class interest'. Yet the managerialist character of corporate globalization is deceptive: on the one hand, it requires the complicity of centralized state managers to negotiate structural adjustment in participation with international financial institutions (IFIs), to privatize national assets and to suppress political resistance; on the other hand, it bypasses centralized state management through the ruthless logic of 'new public management' - a system of autonomization and decentralization where policymaking is divorced from democratic scrutiny, where private NGOs exert disproportional influence on policy development, and where individual government departments must 'compete against one another for central funding, and market-based incentives increasingly become part of budgetary calculations' (Hanieh 2013: 67). The implication of the state in the privatization of national assets not only facilitates the circulation of financial capital as the real subject of global modernity - where value is valorized as the adequate subject bearing the relation of capital - but through increased state borrowing transforms the fiscal function of the state from sovereign redistributive mechanism to net contributor to the international financial system.

Although the popularized myth of 'postindustrial' society suggests a world beyond production and accumulation - a leisure society populated by sophisticated consumers - insofar as they are consumers proletarianization threatens intermediate strata in a material and spiritual sense (Stiegler 2011). Proletarianization entails not only sale of labour-power and loss of initiative/ control, but disindividuation and social-psychological impoverishment. Neoliberalism also undermines working-class capacities at local, regional and global levels, adapting modes of labour intensification, technological innovation and subtle forms of repression developed in the advanced economies to new accumulation regimes in emerging economies - although this process functions in reverse, as rich countries import regressive labour practices from peripheral economies in response to corporate demands for 'flexibility'. In the US, offshoring and unemployment have decimated 'middle-class jobs', turning large parts of the country into 'fourth world' enclaves with impoverished and socially excluded sub-populations, reduced to servicing the needs of a narrow elite. In the UK the gutting of employment law has led to 'zero-hour' labour contracts allowing employers to appropriate labour-power ad hoc, cancelling shifts without warning while demanding responsiveness and obedience from workers whose fear of unemployment and ostracism are intensified by inflows of economic migrants willing to tolerate lower job security and wages.

As Glyn (2006: 119-20) observes, lower pay/fewer jobs is the "nasty tradeoff' for workers in the West, accompanied by a reduction in welfare entitlements. In both America and the EU the precarization of labour is also fuelling right-wing populist demands for the exclusion of welfare claimants and foreigners among indigenous workers encouraged to blame 'metropolitan' elites for their predicament, deflecting resentment from corporate tax 
avoidance, collapsing infrastructure and falling wages. In this way capital shapes its own opposition to globalization and resolves political tensions via a counterrevolutionary interpellation of subjects through (i) state-based narratives fusing identity/power, and (ii) the (re)incorporation of workers into the hedonistic/disciplinary logic of consumerism. The credit-debt nexus thus 'blurs income as a stratification signal, so that knowing someone's income is insufficient for understanding that person's real economic position' (Sullivan 2012: 36). This enables declassed individuals to simulate class positions while reaffirming their actual propertylessness and insecurity (cf. Leicht \& Fitzgerald 2007).

\section{Conclusion}

The 'many faces' of transnational corporatocracy and its consequences for the West are ably documented by Boggs (2011a) in a sustained critique of the new power elite who preside over America's 'phantom democracy'. This analysis extends the arguments of Wolin (2010) and the more pessimistic arguments of Orlov (2011) and Berman (2011), who predict the collapse of the US in its present political form. Yet, it is Barkan (2013) who perhaps most skilfully captures the logic of transnational corporate power, which he defines as coexistent with political sovereignty. For Barkan the modern corporation and sovereign power are grounded in legally sanctioned immunity from law which renders attempts at criticism or regulation by public authority irrelevant. Corporations are legal creations of states which acquire power over those states; but the evolution of corporate-state legal immunity, the victim of which is the public, is best conceptualized as a 'doubling' or 'conjoining', by means of which the political unaccountability of the state is extended to the legal and organizational form of the modern capitalist enterprise.

In Chapter 4 we extend the analysis of capitalist sovereignty to the sphere of global governance, examining the political structures of transnational corporate power which Kurz (1994) terms the regulatory form of the global commodity production system. At the core of this structure is the disciplinary power of international financial institutions which facilitate differential accumulation by enabling dominant capital to extend its control over and capacity to extract value in global commodity chains which allow the formation of the general rate of profit to assert itself (Starosta 2010), and which effectively exclude non-corporate actors from competing in markets, and - if the proposed TTIP and Transpacific Partnership (TPP) are agreed - will penalize public authorities that attempt to impose legal obstacles on corporate trade and investment or access to public contracts. Before proceeding to this analysis, our first step is to analyse the structural and ideological links between the transnational capitalist class and the transnational capitalist state, examining the formal and informal networks of power that transgress and override the interests of workers in national economies. We then consider Wendt's (2003) concept of a world state as a teleological progression towards 
supranationalism. We argue that while the scale and scope of global economic and political governance have widened since the financial crisis, the principal intergovernmental organizations that comprise the state form of transnational capital do not possess the necessary coordinative capacity or supranational power to supersede or override state sovereignties or regional specificities to impose 'governance without government' in a multipolar world. As we shall see in Chapter 4, the emerging yet unstable transnational state form of neoliberal capitalism must be understood in this context, namely as the contemporary global form of the capitalist state. By augmenting the local management of investment and capital flows within national economies and regional blocs, this emergent structure seeks to manage the economic activity of a hierarchized and differentiated global society in its totality through the expansion of the state circuit of capital to meet the needs of overaccumulated capital for valorization and continual self-expansion. And as we shall see in Chapter 5 and Chapter 7, while the US dollar has functioned for seventy years as the monetary conduit for overaccumulated capital, absorbing surplus-value which cannot be reinvested profitably in productive activity, its position as a global reserve currency and safe haven for investors is increasingly in question as the growth of emerging market economies and China's capital markets in particular attract investors away from the West (Lynn 2015).

\section{Notes}

1 The concept of Grossraumordnung was Carl Schmitt's answer to the Monroe Doctrine. He believed Germany should consolidate Europe under its economic and political leadership as the US had done in Latin America. As an imperial sea power in decline, Britain could not tolerate German penetration of the 'Eurasian Heartland', which Mackinder (1904) termed the geographical 'pivot' of history.

2 In Capital volume III (1895), Marx argued that capital expansion indicates an absolute expansion of the technical composition of capital, leading to an increase in the means of production and the mass of labour-power: accumulation also means multiplication of the working class; for accumulation to take place, the poor must remain poor, in a state of need, although this later clashes with their role as consumers.

3 This feature of American politics is revealed in a major study by US political economists who argue that 'economic elites and organized groups representing business interests have substantial independent impacts on US government policy, while mass-based interest groups and average citizens have little or no independent influence' (Gilens \& Page 2014: 1).

4 As Harmes (2008) suggests, cultural nationalism is perfectly compatible with neoliberalism because neoliberals favour economic globalization as a way of promoting the inter-jurisdictional competition (rivalry between competition states for transnational corporate investment and good credit ratings) that they believe consolidates neoliberalism at a domestic-political level. 


\section{The state form of transnational capital}

\section{Introduction}

Writing shortly before the global financial crisis which alerted many to the insolvency and instability of the Western financial system, Olivier Giscard d'Estaing - chair of the French Comité pour un Parlement Mondial, stated that the overwhelming task facing world leaders is to 'restore confidence in the G[7] and global governments and corporations' (D'Estaing 2007: 23). For D'Estaing, the absolute priority for international politics is the consolidation of global governance through an intensification of political interaction between state and non-state actors in order to resolve issues affecting more than one state or region in the absence of a single overarching authority with the power/legal competence to enforce compliance across the domains of global economic and political security.

Reflecting the institutionalist bias favoured by Western liberal elites, D'Estaing suggests two ways of restoring confidence in the public and private institutions of global governance, namely promotion of greater transparency at all levels of public and private decision making, and ethical responsibility in public and corporate life, for - in his esteemed opinion - the "capitalist system does not work if people do not behave in a moral manner, if they cheat or are corrupt' (ibid.: 24). Only if surveillance, visibility and ethical responsibility are ensured and improved will it be possible for transnational elites to consolidate existing institutions of global governance and persuade sovereign governments of the need for supranational cooperation and compliance with some form of global governmental agency (funded by a transaction tax on energy, armaments and transport) to manage more effectively the tensions of capitalist globalization. ${ }^{1}$ Only a genuine transnational response to the crisis, argues D'Estaing, can address the political-economic contradictions of neoliberal globalization by enhancing institutional structures to legitimate corporate power and ensure effective rules-based governance of the global economy (cf. Garnaut 2013; Boyle 2010; Hicks 2002).

In this chapter we examine debates on the implications of corporate globalization for global governance and transnational policy coordination after the global financial crisis, building on the analysis of capitalist sovereignty 
and corporate power. Although our main focus is the regulatory power of the global state form of capital - capital decoupled from the political constraints of national economies based on a fusion of identity and power - it is also essential to consider the structural interrelation between capital organized through international financial institutions and the regional, sub-regional, national and sub-state political forms of capital as these have emerged in the long development of the capitalist world system. This complex interrelationship is in a condition of flux as leading powers struggle to develop coherent forms of multilateral governance to manage the contradictions caused by uneven economic development and the monetary turbulence unleashed by a crisis that has exposed the fragility of the liberal international order.

Whether the liberal order can transcend the structural logic of anarchy in international relations depends not only on the capacity of contenders such as China to adapt to the norms of 'international society' and 'rise peacefully', but on the willingness of Western financial and security elites to adapt to the need for genuine multilateral global governance by enabling emerging market economies to exercise a level of decision-making power in proportion to their growing economic weight. It is in the "most powerful clubs of states (the WTO, IMF and World Bank) that neoliberalism is triumphant' (Murphy 2000: 797), yet it is simply not possible to explain the 'nature of global governance without understanding the ways in which powerful states construct and pursue their strategies' (ibid.). From a rationalist perspective, orderly transition towards a multipolar international system is unlikely as inadequate incentives exist for Western elites to settle for positive-sum gains and relinquish their prerogative to determine geopolitical outcomes through offensive diplomacy, statecraft and war.

This interpretation is supported by the attempt by the US to exploit the crisis in Ukraine to isolate Russia in the G20 precisely as the US was under pressure for failing to ratify reforms to IMF governance agreed by the G20 in the wake of the global financial crisis (Stuenkel 2014). Indeed, America's brinkmanship contradicts the early 'G20 spirit', according to which 'advanced economies would support a greater voice for emerging economies in global governance arrangements and the latter would take more responsibility as full-fledged stakeholders of the global economy' (Lombardi, cited in Callaghan 2014: 1). ${ }^{2}$ To this extent, at least, Bremmer's (2012) conception of a 'GZero' world order in which no state or alliance of states can provide global leadership, seems disquietingly correct. This failure to embrace multilateralism, argues Lombardi, is likely to 'give new momentum to regional alternatives like the Chiang Mai Initiative which set up currency swap lines between [...] Asian countries' (ibid.). It is also likely to accelerate the development of international monetary reset as the BRICS economies move to establish their own currency-swap arrangements and conduct trade outside the dollar system (Chandran 2015). Western condemnation of Russia over its policy in Ukraine reveals the link between Western financial and security interests after Russia - in its bid to promote multipolarity - hinted in January 


\section{The state form of transnational capital}

2014 that the G20 should proceed with IMF governance reforms without explicit US support (Harding 2014). Yet prevarication by the US is unlikely to silence calls from emerging economies for reform of transnational institutions to limit the fallout from Western mismanagement of the global economy and to expedite the introduction of a suprasovereign global currency based on the IMF special drawing right (SDR) model (Yong \& Pauly 2013).

As a precondition for the reproduction of capitalist relations of power, sovereign states do not cease to exist in a financialized global economy. In contrast with traditional geopolitics which is defined by the logic of 'national security', capitalist geopolitics is defined by what Apeldoorn (2014) terms 'ruling class security'. Within the emerging global totality, the state becomes 'immanent to the field of social forces, enters into their service, and serves as a regulator of the decoded and axiomatized flows' (Deleuze \& Guattari 1977: 235 , emphasis added). Indeed, it is important not to view the interrelation between world space and national territoriality as a

zero-sum game in which the importance of the former is presumed necessarily to entail the decline of the latter. By conceiving geographical scales as mutually exclusive rather than as co-constitutive, relationally intertwined levels of social interaction, this dualistic conceptualization cannot adequately theorize the essential role of sub-global transformations - whether of supranational political-economic blocs, national state territories, regions, cities, localities or places - in contemporary processes of global restructuring.

(Brenner 2011: 122)

The question is not whether the state form of transnational capital has undermined the national state by appropriating its powers, but how states will execute their competences in an integrated global economy. Despite predictions of its demise by 'hyperglobalists' (Friedman 1999; Jha 2006), the Westphalian state identified by Gellner (1983), Mann (1993) and Giddens (1985) as a 'power container' remains an effective structure for managing the contradictions between security, identity and sovereignty, ensuring the stable organization and reproduction of its internal properties. Yet the role of the state is being transformed through the assertion of capitalist sovereignty and the development of interlocking arenas of transnational agency corresponding to the changing juridical requirements of capital. To understand this process it is essential to consider the triadic structure of interstate, intercorporate and corporate-state bargaining which characterizes global political economy (Stopford \& Strange 1991).

The state form of capital is a dimension of political-ideological organization which stands above social reproduction yet remains integral to it. While cosmopolitans embrace supranational agencies that transcend the juridical limits of sovereign power (Held 1995; Archibugi 2003), critical theorists approach global governance with scepticism: who, or more precisely what, do 
these emerging structures/global actors represent, and how can they be made accountable? (Peet 2009).

To understand corporate globalization, we must explain how the state form of capital sustains the juridical conditions for global accumulation, for the core indispensable function of the capitalist state is neither to reproduce the necessary illusion of a neutral political order standing above class divisions based on property ownership, nor to establish the general societal interest in atomized societies, but to ensure the continuous uninterrupted reproduction of total social capital. While it is impossible to derive the content of state power from accumulation in any direct sense, 'the starting-point for the analysis of this activity, of the development of the state and its limitations, must be the analysis of the process of accumulation and its contradictory development' (Holloway \& Picciotto 1978: 25).

The tendency towards absolute overaccumulation reveals both the dynamism and inner limits of capital: in all branches of production and exchange this tendency appears as rivalry between concentrations of corporate power for control over human and material resources. This creates a contradictory tendency where corporations maximize expected profits on the one hand by expanding the productive capacity of the societies in which they operate beyond the limits of the market, while on the other hand production is periodically returned to the limits of the market by collapsing economic activity at the cost of destroying productive capacity which fails to generate expected rates of surplus-value. This process operates across spatial scales but typically leads to global recession because there are no geographical limits to the collapse of demand in the core consumer economies. Capitalist value is therefore indistinguishable from crisis, and its expansion and contraction develops through recurring cycles of decadence, destruction and renewal, reestablishing conditions for accumulation while enabling consumers to forget the origins of previous crises in the overrapid expansion of economies, the irrational exuberance of asset-price inflation and unrealistic performance of the financial sector through the growth of new synthetic values (Jameson 2011).

In the following sections we examine the institutional structures of financial regulation which facilitate the directionless expansion/contraction of capital in the global economy and the consolidation of capitalist commodity chains within and between territorially demarcated regimes of production and consumption. Here it will be necessary to review developments in the literature on global governance, focusing on the debate between institutionalists, internationalists and cosmopolitans who attach normative significance to supranational policy coordination, neorealists who question the viability of transnational governance and the capacity of intergovernmental institutions to enforce multilateral decisions, and critical theorists who highlight the dangers of technocratic governance as the alienated political form of corporatism. We then examine the surveillance function of transnational institutions which articulate capitalist sovereignty, imposing financial discipline on the global 
economy. Our primary concern is not the legal competence of IFIs or their capacity to enforce compliance - issues dealt with elsewhere in the literature (Djelic \& Sahlin-Andersson 2006; Picciotto 2011; Kirton 2013; Avgouleas 2012; Lin 2013), but the channels through which capitalist sovereignty is projected and diffused in a decentred global capitalist order. Institutions of global governance continue to privilege transatlantic interests, despite the shifting centre of gravity in international trade towards emerging economies. The implications of this contradiction are clear, for in a decentred global economy increasingly managed by private corporations, the West dominates the international community but is no longer in a position to determine the future of globalization because capital is no longer concentrated exclusively in Western financial centres.

\section{Towards a world state?}

Few observers question the importance of global governance in international politics, yet there is disagreement over the extent to which institutions of global governance possess the multilateral authority or legitimacy to resolve global issues. There is also disagreement over the extent to which global governance can evolve into a consolidated form of 'world government' - a world federation with executive authority, supported by a world parliament and world court, with a mandate to make decisions binding on all states. ${ }^{3}$ Realists stress the contradiction between sovereignty and transnational organization, arguing that attempts to enforce supranational authority fail if confronted by noncompliance or defection by principals. Yet government and governance are distinct concepts: 'governance should not be understood as a weaker or less developed form of rule because it lacks a unified government. Although global governance may seem amorphous, it operates at more levels than formal systems' (Sinclair 2012b: 28). It is the decentred and diffuse character of global governance that distinguishes the state form of transnational capital from earlier experiments in liberal internationalism which sought to impose norms of interaction on a fragmented world.

Discussing the changing nature of transnational governance following the global financial crisis, one conservative journalist observes that the word global has acquired 'sacred connotations': 'Any action taken in its name must be inherently virtuous, whereas the decisions of individual countries are necessarily "narrow" and self-serving. (Never mind that a "global agreement" will almost certainly be disproportionately influenced by the most powerful nations.)' (Daley 2009: 14). Reflecting the natural scepticism of the conservative mindset, however, she adds:

There is a whiff of totalitarianism about this new theology, in which the risks are described in such cosmic terms that everything else must give way. 'Globalism' is another form of the internationalism that has been a core belief of the Left: a commitment to class rather than country seemed 
an admirable antidote to the 'blood and soil' nationalism that gave rise to fascism.

Daley is fearful of globalist projects that detract from the discursive legitimation of the nation-state, and associates 'globalism' not with the internationalization of capitalist relations of power but with a socialist world state which, like the Soviet Union, would presumably develop into a similar model of tyranny (cf. Goodman 1959). Yet the idea that globalization is leading to socialism is unsustainable, even if conservatives indicate parallels between the Soviet Union and the EU as 'failed' experiments in supranationalism based on the coercive alignment of interests between nations. It is no less misleading to conflate Marxism with the positivistic form of historical materialism popular during the Second International. The real subject of global modernity is not a class for itself that personifies the 'spirit of the age', but the relations of power constituted by capital whose sole purpose is value augmentation - a 'purely quantitative measure of its achievement which negates all content' (Arthur 2002: 141).

The conservative equation of globalism and socialism has so far failed to gain resonance among a depoliticized generation that takes globalization for granted. The appeal of reactionary anti-globalism is restricted to nationalists and neofascists who reject prima facie all forms of supranationalism that detract from the inward-looking orientation of culturally bounded 'communities of fate', or who equate the emancipatory potential of capitalist modernity with the 'totalitarian straightjacket of egalitarianism' (Krebs 2012). ${ }^{4}$ Globalization has indeed led to a partial homogenization of distinctive cultures, often obliterating the traditional existence of autochthonous peoples unable to adapt to the rationalizing effects of capitalism. Yet few serious observers equate the uneven development and iniquitous distribution of wealth created by neoliberalism with 'global socialism' (Svedberg 2004; Rapley 2004; Navarro 2007; Lazzarato 2009; Collins et al. 2008). On the contrary, the main consequences of globalization are: (i) growth and intensification of intergovernmental decision making in the management of global monetary and trade issues; and (ii) a disaggregated network of overlapping global, regional and transregional regulatory authorities to manage the security and environmental threats affecting multiple states where no means of compliance exists, as a result of which participant states show a propensity to converge towards similar forms of political and legal administration, either voluntarily or to avoid violating global norms.

Global regulatory institutions are considered valuable because they 'create norms and information that enable member states and other actors to coordinate their behaviour in mutually beneficial ways' (Buchanan \& Keohane 2006: 3; cf. Keohane 1984). In addition, they 'reduce transaction costs, create opportunities for states and other actors to demonstrate credibility, thereby overcoming commitment problems, and provide public goods, including rule- 
based resolution of conflicts' (ibid.). However, it is immediately apparent that any transnational 'institution can only perform these functions if those to whom it addresses its rules regard them as binding and if others within the institution's domain of operation support or at least do not interfere with its functioning' (ibid., emphasis added).

The challenge of global governance has led to contradictory responses from the principal theoretical traditions in IR and IPE reflecting the wide divergence of academic opinion on the extent to which norms of reciprocity regulating international society can be formalized into transnational rule-making institutions, and the extent to which this development is necessary, desirable or inevitable. While liberals and English School theorists stress the importance of reciprocity and multilateralism as evolving features of international society, reflecting an ideal-typical interpretation of world order based on a projection of Western values in international relations theory (Keene 2009), critics insist that transnational rule-making regimes only mitigate the structural logic of anarchy in international relations by advancing temporary and/ or limited modes of cooperation because: (i) their authority is contingent on the willingness of sovereign actors to acknowledge the validity of rules to structure collective behaviour and restrict some actions; and (ii) such institutions are unlikely to survive the eclipse of a hegemon with the determination to defend a given status quo and the international authority to enforce minimum standards of compliance (even where the hegemon itself refuses to comply).

From a realist perspective the geocentric idealism of liberalism is indicative of a flawed commitment to supranationalism which runs through internationalist and cosmopolitan ideologies of power - positing a unified global social order 'stripped of power, national interests, and interstate conflict; its proponents envisage a world nearly devoid of either domestic or international politics, a world in which technocrats, bureaucrats and experts can solve issues outside the realm of domestic and international politics' (Gilpin 2000: 245; cf. Schmitt 1950). Realists are willing to recognize opportunities for conditional cooperation where unified state actors remain the primary units of political rule and the potential for interstate conflict is structurally determined and omnipresent, but 'peace' is understood as a period of subdued rivalry between two or more periods of open hostility, because states have an 'incentive to conceal or misrepresent information to gain strategic advantage' (Mastanduno 1999: 22). On this view, states are concerned largely with ensuring freedom from threat in a world where enmity is inescapable: not only are periodic outbreaks of conflict inevitable - either because states seek relative gains from conflict or fail to prevent crises from escalating into open warfare - but cooperation between states within transnational institutions is dependent on perceptions of relative advantage. Even critical realists such as Bacevich (2008) who disavow US exceptionalism defend a definition of exclusive sovereignty that privileges state actors as primary units of analysis in IR, questioning liberal theories of normative commitment and 
constructivist theories of structural/ideational change that emphasize the mutual constitution of international society based on a 'logic of appropriateness' (cf. March \& Olsen 1989).

For institutionalists, by contrast, transnational regulatory regimes are a 'necessary component of the international system which arise out of the selfinterested cooperation between states' (Emadi-Coffin 2002: 9). Rosenau (1992) argues that the purpose of governance is to create a plurality of mechanisms for steering global processes. In response to neorealism, neoliberals highlight a broader range of shared policy goals in the transition from state-centric geopolitics to supranationalism, leading to consolidation of a rules-based order integrating autonomous territorial units. As Keohane (2001: 1) argues, 'interdependence and the lack of governance, when combined, make a deadly mixture'.

For Keohane and Nye (1997), global governance presupposes a plurality of channels of action in the organization of interstate and supragovernmental relations, which implies recognition of three phenomena, namely: (i) multiple channels linking complex societies, including interstate diplomatic relations, transgovernmental relations between nongovernmental elites, and transnational interconnections between non-state actors; (ii) multiple international agendas (economic security, environmental protection, etc.); and (iii) a presumption in international society in favour of a norm ruling out the unilateral use of military hard power to resolve territorial disputes. Despite its origins in liberal political theory, neoliberal institutionalism retains a strongly realist emphasis on the centrality of rational state actors in international relations 'unified entities with particular, specifiable goals, rather than composites of many different domestic actors and competing interests' (Sterling-Folker 2010: 117). Transnational cooperation and norm compliance are feasible but only where states identify opportunities to advance their self-interest through collective action. Institutionalists assume general recognition of the need for compliance with rules-based regimes, but even where global institutions create expectations of future interaction ('iteration'), such cooperation may be difficult to sustain in a geopolitical order characterized by uncertainty and insecurity.

Focusing on the absolute rather than relative benefits of long-term functional interdependence and cooperation with transnational regulatory regimes, neoliberals depart from the neorealist paradigm, yet neoliberalism offers an essentially static model of international politics reminiscent of normative functionalism: by emphasizing the capacity of transnational institutions to enforce world order, and by exaggerating the importance of institutional design as a way to increase compliance, the model assumes the infinite reproducibility of the existing balance of power and thus fails to provide a dynamic theory of change in the world system linked to economic development. Institutionalism is thus conservative in orientation: its purpose is to sustain an eternal present in the interests of Western capital which rules out alternative modes of cooperation and emancipatory development (Agathangelou \& Ling 2009). 
Moving beyond neoliberalism, internationalists and cosmopolitans posit theories of world order and supranational democracy that build on complex interdependence, but also call for just institutions, moral reciprocity and 'citizen efficacy' as counterweights to Realpolitik (Cabrera 2004). This normative approach reflects a universalist tradition in Western political theory dating back to Ancient Greece, whose thinkers identified (i) the need to define a common purpose for civilized mankind, and (ii) enduring peace as a condition for the realization of human potential.

Transgressing the doctrine of exclusive sovereignty, a democratically constituted international community acting in and through multilateral institutions constitutes more than a 'great power concert' and thus enjoys a cosmopolitan prerogative to override sovereign exceptionalism to advance the concerns of liberal universalism - according to which the 'universal' principles associated with the Western Enlightenment tradition (individualism, secularism, materialism, etc.) should apply to all states regardless of their cultural heritage. Contra Rawls (2001), who rejects a unified global regime with the legal power of government as a potential source of tyranny (and perpetual warfare), cosmopolitans stress that world citizenship requires more than simple adherence to mutually acceptable legal norms, for if we take seriously a universalist approach to moral obligation beyond state borders, then there is no option but to strive for supranational political and legal structures to distribute resources and enforce compliance with norms in international law (Cabrera 2004).

On this view, global governance becomes an 'arena within which the interests of both states and agencies of civil society are articulated and reconciled in the process of global policy formulation' (McGrew 2011: 279), although recent studies focus more specifically on the problems of multilateral coordination, legitimacy and accountability that bedevil attempts to institutionalize 'postsovereign' decision making, particularly in the evolving informal convening power of the G20 (Subacchi \& Pickford 2011; cf. Wouters \& Ramapoulos 2012; Kirton 2013; Smith 2014). As Scholte argues, there is a 'danger that governance agencies exploit these postsovereign circumstances of diffuse polycentric decision making to avoid accepting responsibility for their actions and omissions' (Scholte 2011: 19). However, he cautions, 'to reaffirm accountability in respect of polycentric public policy networks requires a shift in assumptions away from a now obsolete "sovereigntist" mindset that seeks to attach ultimate responsibility to a single highest authority' (ibid.). This point is echoed by Bjola and Kornprobst, who stress a tension between demands for collective action and the fragmentation of collective agency created by the privatization of political power in international politics: collective action, they argue, 'sustains global ordering, while fragmentation of collective agency undermines it. This fundamental summarizes the main challenge of global governance: how to create political order among a multiplicity of actors having different identities [...] and power resources' (Bjola \& Kornprobst 2011: 3). 
Whether cosmopolitanism has a future outside scholarship depends on whether states might be willing to support the actual development of diffuse and flexible forms of popular global participation, and whether 'global citizens' could acquire the competence to support these systems and fashion a moral framework for international relations (cf. Heater 2000: 191). This is doubtful, for while cosmopolitans seek to augment existing interstate arrangements to enhance accountability/legitimacy, transnational institutions with extensive regulatory powers might in fact contradict the liberal demand for limited government (McGrew 2011).

Yet for supporters of a postsovereign global order, governance with government remains inadequate to the task of enforcing global justice and resolving planetary issues. The solution is a globally empowered political authority with the right to override sovereignty - a world federation with the power to transcend the legislative and executive limits of intergovernmentalism in the domains of global political economy and international security, leading to the possibility of governance without government - a new 'political order with other means or through other modes than with classical government tools' (Guzzini 2012: 4). In this vision, argues Guzzini, 'governance is not thought of in terms of (state) government but beyond it; indeed, order through government (by whatever actor) is but a part of governance' (ibid.). This implies new systems for steering, coordination and regulation in which transnational organizations act in accordance with their own supranationally constituted authority to formulate policy on behalf of states, in partnership with corporate and non-state actors, leaving states to implement supranationally constituted policy within their own limited sovereign jurisdiction.

Yet two objections to this ideal can be identified: on the one hand, while issues of high politics can be co-determined within a security alliance such as NATO, they cannot be democratized because they are decided by professional elites responding to the exigencies of international politics which citizens are powerless to understand or influence; on the other hand, even where states are internally democratic or encourage a positive spill-over effect for foreign policy, this is no guarantee for a democratization of international politics because in spite of the interdependencies created by globalization, the allocation of resources in the global economy is determined by private corporations rather than public authorities.

Nevertheless, federalists such as Tännsjö (2008) look towards the EU to support their demand for genuine supranationalism. As the most advanced regional organization, the EU is presented as a model for transnational democratic coordination which could be emulated at a transnational level by creating a 'world parliament' to deliberate on the formulation of international law on the model of the European Parliament in Strasbourg (Tetalman \& Belitsos 2005). Despite its treatment of Greece as the weakest economy in the eurozone (and its interference in Greek and Italian democracy with the appointment of non-parliamentary caretaker governments in 2011), neofunctionalists applaud the EU as a beacon of Enlightenment values and 'soft 
power projection' which states along its eastern and southern periphery are encouraged to emulate (Joffé 2001). Trends towards constitutionalism in the $\mathrm{EU}$, it is argued, have transformed the EU from a 'treaty-based intergovernmental regime to an entity representing an embedded continental liberal market order underwritten by an emphatic corpus of supranational law' (Rosamond \& Wincott 2006: 1). However, Europeanization has led to a situation where

the 'imagined community' of the nation which served as the affective basis for the post-French Revolution social contract, as well as its modern institutional counterpart, the welfare state, is [...] under critical duress as states lose control over what were once referred to as the 'national economies'.

(Trägårdh 2004: 2)

Under the leadership of Germany and France, member states have been reformed into 'complex structures of strategic coordination', leading to a partial destatization of the Union as a regional political structure of transnational neoliberalism (Jessop 2004: 65). This has intensified the 'ecological dominance' of financial capital over competing fractions of capital in the regional political economy of Europe and its near periphery, where 'profitoriented, market-mediated capitalist economic order [... exerts] a greater impact on the evolution of other social orders than these orders have on it' (ibid.: 74). As the monetary and fiscal problems of the eurozone have revealed, the contradiction between capitalist sovereignty and capitalist democracy has led to a crisis in the 'spatio-temporal fix' of multilevel regional governance, for despite facilitating a sophisticated articulation of interests via a hierarchy of decisional scales, financial capital 'can freely jump these scales, while accompanying modes of social regulation cannot perform this feat so easily' (Kramsch \& Hooper 2004: 5).

The flight of capital from Greece in 2011 and the angry response towards George Papandreou's proposed referendum to facilitate Greece's exit from the eurozone indicate the depth of the contradiction between supranationalism and popular sovereignty, which resulted in the collapse of the Greek economy, the resurgence of Greek fascism, and the reperipheralization of the Hellenic state. ${ }^{5}$ Those who defend the ideal of a capitalist peace based on the assumption that private property rights and contractual obligations encourage cooperation or that market economies are better able to 'indicate resolve' overlook the financial violence inflicted by the 'Troika' (IMF/European Central Bank/EU Commission) that prevented Greece from reasserting its monetary sovereignty and defaulting on its 'odious debt' - a debt inherited from past authoritarian governments, which forces peripheral economies to become net creditors to the rest of the world (Manolopoulos 2011; cf. Woodley 2013).

Ironically the cosmopolitan ideal can be traced back to Antiquity, for allusions to the idea can be found in Aristotle's famous letter to Alexander of 
Macedon, suggesting that the interests of classical civilization could best be served through the achievement of 'lasting peace' (Stern 1968: 35). Aristotle calls for a focus on that which is 'common to all men' (ibid.: 41), although Alexander's own more modest and pragmatic goal was to co-opt the Persians into his unified empire through limited self-rule under his suzerainty (cf. Heater 1996). As Stern notes, while Aristotle's letter 'speaks of all men living in concord, it does not expressly say that they will live together in equality [... his] interest is centred on the future happiness of mankind brought about by general peace rather than on equality between Greeks and barbarians' (ibid.: 42).

The ideal of world government subsequently reappears in European history, and is typically linked with 'benign hegemony' - that is to say, under benevolent leadership geopolitics is 'frozen' and 'world union' achieved without tyranny. This theme takes shape in the writings of pan-Europeanists of the early modern era, including the Project for Perpetual Peace by Abbé SaintPierre, and the General Consultation Concerning the Improvement of Human Affairs by Johannes Komensky (ibid.). Other examples can be found, indicating the continuity between Enlightenment cosmopolitanism and Renaissance neo-Stoicism, leading to the famous defence of 'global pacific federation' in Kant's Perpetual Peace. In contrast with Hobbes, who favoured a lawful interstate order, and Rousseau, who believed in the moral perfectibility of states, Kant saw world republic as desirable yet implausible. Instead he stressed the possibility of domestically well-ordered republican states which would be less likely to precipitate conflict. Heater identifies five types of appeal in the literary output of cosmopolitan thinking:

The first appeal is the felt need to give political reality to the belief that states are artificial in the context of the recognised essential unity of mankind. Second is the crude urge for world power. Thirdly, some ideologies have contained the ambition of their worldwide political accomplishment. In the fourth place, much support has been accorded the idea of world political unity because of the proclaimed practical benefits that would flow from the arrangement. Finally, the possible methods have ranged from conquest to acceptance of mass popular will.

(Heater 1996: 202)

It is this belief in a foreordained destiny that drives constructivists like Wendt (2003) to assume the inevitable emergence of a world state through teleological reasoning, positing world government as an outcome linked to a design or purpose implicit in and necessary for the fulfilment of human history.

Falk defines world government as a political system founded on 'compulsory peaceful settlement of all disputes by third-party decision in accordance with law; general and complete disarmament at the state and regional levels; a global legislative capacity backed up by enforcement capabilities; and some form of centralized leadership' (Falk 1995: 207). While world government may appear unfeasible in practice, for Wendt it is 'made inevitable by the 
interaction between a self-organizing, bottom-up process and a structural, top-down one: struggles for recognition mediated by technological change at the micro-level, conditioned by the logic of anarchy at the macro[-level]' (Wendt 2003: 494).

On this view a world state is both desirable and inevitable given the demand for security, enabling collective identity formation and collective political authority to reduce the risks posed by the production of new destructive military technologies. This process, he believes, will lead to a 'universal security community' - that is to say, a supranational authority mandated to make binding decisions over the use of coercion. Eventually, the resistance of powerful state actors who enjoy the benefits of sovereignty will be reduced as they find it more difficult to insulate themselves from escalating risks and violence. Humanity has three choices, namely a pacific federation of republican states, an anarchical society with states as self-sufficient totalities, or a world state. As it is currently constituted, the international system must inevitably evolve towards world government as a 'stable end-state', although Wendt recognizes that this supranational authority would co-exist alongside the irreducible pluralism of national cultures, and that a centralized supranational executive would be unlikely:

As long as binding choices can be made, decision making in a world state could involve broad deliberation in a 'strong' public sphere rather than command by one person. In short, as long as it has a common power, legitimacy, sovereignty and agency we should not prejudge the form a world state might take. The EU is already not far from meeting these requirements on a regional level. Were a 'completed' EU to be globalized it would be a world state.

(Wendt 2003: 506)

He accepts that great powers will resist surrendering their right to the unilateral use of force, yet insists that in a world of 'rogue powers' with destructive military arsenals it will be rational to join a world state with security based on an extension of the 'NATO model' rather than a United Nations (UN) army: 'Individuals and states alike will have lost the negative freedom to engage in unilateral violence, but gained the positive freedom of fully recognized subjectivity. The system will have become itself an "individual" (Wendt 2003: 525).

In response to Wendt, realists argue that without a means to overcome social and cultural homogeneity world government is an impossibility. In addition, a world state could hardly function as a disinterested 'technocratic actor' supplying impartial justice because its officials would inevitably be driven by their own functional interests and priorities - precisely as the European Commission has developed interests at variance with those of its 28 member states (as in the case of Greece). Although a hypothetical world state might reduce the incidence of military conflict as the 'court of last resort in a 
world of anarchy' (Tetalman \& Belitsos 2005: 78), for realists a plurality of states that preserves the unique qualities of nations is preferable to a monolithic entity controlled by a universalizing governmental rationality. This argument was emphasized by Schmitt (2003), who observed that a perfectly functioning world state would close off the possibility of the political by eliminating the 'empty space' necessary to facilitate future historical action, 'creating a perfectly ordered world that excludes the possibility of conflicts and resistance - at least any meaningful resistance' (Ojakangas 2007: 208). Such a world would be 'devoid of meaning, because it would become an automaton, a "self-propelling machine" (ibid.). There must be something that still stands outside and transcends this perfectly functioning order - a vital space for political action as a condition of possibility for rupture and, therefore, for the enactment of constituent power. As Schmitt argued cryptically in Political Theology, it is through the exception that the "power of real life breaks through the crust of a mechanism that has become torpid by repetition' (Schmitt 1985: 15).

Wendt also comes in for criticism by IR scholars opposed to realism. Shannon (2005), for example, argues that because agency is denied by the logic of inevitability in his teleological method, Wendt seems ready to abandon the constructivist emphasis on contingency and indeterminacy in the intersubjective production of institutional norms and practices in international politics. Furthermore, Shannon argues, Wendt views struggle for recognition as an exclusive monocausal motive for agents, and his excessive emphasis on inevitability makes it difficult to examine or even imagine the unpredictable social and political context in which a world state might actually come into being. Instead, Wendt predicts transnationalism as an outcome conditional on nationalism, where submission to a supranational global authority on a macro-level follows a struggle for national recognition at the micro-level:

Wendt's reference to nationalism acknowledges both the influence of non-
state agents and the potential for system disintegration, yet he tries to
reconcile this with his teleology by claiming that such a 'step back' is a
'precondition for moving forward'. In fact, Wendt says a [world state] is
only possible if it embraces nationalism, which seems contradictory since
nationalism is about self-rule and statehood. (Shannon 2005: 584)

In Wendt's defence, there are historical occasions when precisely this has occurred - for example, the accession of Eastern European states to the EU after the collapse of the Soviet Union. Yet as a general theoretical position, Wendt's reasoning makes little sense because 'fragmentation is rewritten as evidence of consolidation, raising falsifiability problems as well as the logical conundrum of why new nationalist groups achieving independence from tyranny would turn and submit to another superstate' (Shannon 2005: 85). 
For constructivists, the flaw in Wendt's reasoning lies in his methodological assumptions, namely a scientific-realist commitment to the unitary actor in IR theory: while Wendt is a leading figure in constructivism, he is biased towards systemic constructivism, and approaches his task from within the state-centric framework of realism. He therefore 'risks becoming hijacked by this orthodoxy: his theory must reproduce it [...] Through his statist theory, he reproduces the embedded understanding of politics of a narrowly defined international society - which might appear out of touch with world politics' (Guzzini \& Leander 2006: 74; cf. Reus-Smit 2005a).

Wendt belongs to a tradition of social theory strongly committed to synthesis, and the point of his intensely theoretical labour is to 'abstract, reconfigurate, indeed sometimes "assimilate" apparently antagonistic theoretical positions within one (his) social theory' (Guzzini \& Leander 2006: 73). He also problematizes the epistemological assumptions of rationalism in neoliberal/neorealist debates, affirming the intersubjective and ideational construction of social reality which reproduces structures that in turn acquire quasi-permanent features that reflexively order the lives of individuals. From a Marxian perspective, however, the obvious conceptual weakness of idealism lies in the assumption that the structure and organization of international trade and security are products not of material determinations but of ideational processes conditioned through mutually constitutive intersubjective engagement. This recalls Giddens's (1984) theory of 'structuration', where structures are no longer immutable reified constructs external to individuals, but constituted through a reproduction of social patterns institutionalized in specific contexts.

For neo-Gramscians who dislike Cox's (1983) reconstruction of historical materialism, this problematization of structure is not unwelcome: it highlights a political need to explain how hegemonic structures are embedded in the norms and practices of national and transnational communities - and how a philosophy of praxis (collective emancipatory action) must simultaneously function as a critique of common sense understanding by a transnational intellectual-moral bloc in order to begin to reveal and overcome ideologically determined social divisions (Rupert 2006; cf. Bedirhanoğlu 2008; Lacher 2008). Yet for those who refuse to reduce structure to intersubjective relations (collapsing material objectivity into historical subjectivity), this approach fails to explain the objective domination implicit in embedded structures of capitalist power, which in the present state of neoliberal globalization acquire political valence through formal and informal global governance - transnational disciplinary regimes that augment traditional structures of political power organized through the state.

As Joseph (2008) argues, there is little to be gained from denying that structures possess a logic: capitalist relations of power can be understood analytically, for capital exhibits an inner logic that can be accessed though a dialectical analysis of its main categories. Hegemony should not, therefore, be 'contrasted with either social structure or material conditions. Rather, these 
are its very conditions of existence. Unless we have a structurally grounded approach, there is little basis for understanding the powers and possibilities that agents may possess' (Joseph 2008: 68). Rarely, he adds, is there 'direct reciprocity between structure and consciousness. Social structures have a real existence that is ontologically distinct from our intersubjectivity and consciousness' (ibid.: 70). As we saw in Chapter 2 and Chapter 3, the structures of capitalist power constitute a totality of social relations determining the framework of choices available to individuals and state actors, and the point of Marx's theoretical intervention - which Althusser recognized - was to analyse the economic level of deep structural relations of power (Scott 2012: 190). In addition, the sociomaterial conditions of capitalist power have an objective existence grounded in the reflexive domination of abstract labour over itself: abstract labour is not merely the 'object of domination and exploitation but is itself the essential ground of domination' (Postone 1993: 125-26). The reproduction of capitalist relations of power presupposes the existence of propertylessness workers whose labour-power constitutes a vital (but not exclusive) precondition for generating value. As the real subject of globality, capital constitutes itself as a self-valorizing force, subsuming human creativity, political initiative and energy in its inexorable logic, outside which little of value can flourish.

The asymmetric structures of power that govern the political economy of world order are inaccessible and resistant to normative critique - not because critical theory is devoid of normative foundations, nor because there is an inevitable contradiction between the interests of global financial investors and embedded political structures, but because the state form of transnational capital that constitutes global governance bears little real relation to the cosmopolitan idealism of liberalism or the supranational global authority posited in Wendt's systemic constructivism. Although cosmopolitan idealism draws on a tradition of Western philosophical idealism that conceives world order as an indirect effect of the internal ordering of states, it excludes from its analysis any formal consideration of the material logic of capitalist sovereignty in the globalization of corporate power and the institutional logic of transnational governance as a response to deterritorialization, which reflects the complex geopolitical challenge of embedding the transnational market power of dominant corporate capital in legitimate non-market institutions (Ebner 2011; cf. Polanyi 1944).

Indeed, cosmopolitans not only elide the implicitly ideological character of liberal universalism in the Eurocentric idealization of 'international society', but in their advocacy of governance, free trade and humanitarian intervention, they casually dismiss the political virtues of sovereignty for developing societies in the capitalist periphery that struggle to limit neocolonial dependency. That is to say, cosmopolitans overlook as a matter of course the economic and political utility of sovereign power for weak Third World states that seek autonomy and security either by staggering their historic exposure to global market forces (for example, Brazil), or by relying on norms of non- 


\section{0}

The state form of transnational capital

interference and reciprocity in international law (for example, Iran) as a way to limit intervention by industrialized economies or global institutions acting on behalf of corporate actors, and which thus have less to gain from submission to Western-led global governance (Bello 2009; Evans 2011). Cosmopolitans and constructivists who attempt to deduce the normative and functional desirability of a 'world state' from the perplexing plurality of transnational institutions and regulatory regimes fail to perceive that the acceleration and intensification of capital flows cannot be managed through traditional systems of regulation because the institutional forms of global governance exist to articulate and consolidate the financial interests of corporate power which transgress all jurisdictional limits. Cosmopolitans who assume that global economic integration must lead to suprasovereign decision making for the collective good of international society thus not only ignore the material determination of capitalist geopolitics that forces states into ruthless monetary and trade wars, but also the non-identity of interests between revisionist contenders which paradoxically unites states outside the Lockean heartland.

This faulty perspective is exemplified in the work of liberal globalists such as Boyle, a Hegel scholar who posits supranationalism as a rational political response to economic interdependence. Up to the present time, he contends, governments have

conspired with each other, against their peoples, to maintain their own freedom of action, in response to the threat of supranational regulation implicit in the growth of global trade and finance. But the illusion of their omnipotence, which they have fostered, threatens to destabilize them, perhaps for good [... The] world financial crisis is in fact the beginning of a world political crisis. What went wrong with globalization after 1989 was not simply that the expansion of commerce remained too regulated. Rather it was that, with the partial exception of the World Trade Organization, no regulation at all - political, military or economic - was established at the global level at which the human race was becoming interconnected and interdependent.

(Boyle 2010: 28-29)

This projection of a world state in idealist thought constitutes a false ontology - a failure to grasp not only the absence of a unifying political centre, but that the self-valorizing logic of capital itself is ungovernable. Transnational governance constitutes a complex (yet partial and incomplete) interlocking network of transnational authorities, informal regulatory regimes and parapolitical modes of clandestine private governance which defy simple classification - even within the systemizing framework of Marxist IPE. Globalists like Boyle may be correct to argue that the global financial crisis marks the beginning of a more serious 'world political crisis' - paving the way (negatively, in his view) for a return to multipolarity. Yet the new nomos of the earth is structured less by governance as 'soft' rule making than by the 
disaggregated power of transnational capital whose supremacy over competing national capitals and leverage over national political institutions is sufficient to block demands for effective regulation of the financial institutions that engineered the global crisis.

While transnational governance may be considered a functional precondition for the supranational consolidation of market rationality, it is no substitute for the localization (Ortung) of violence in demarcated zones of economic production and political exclusion which facilitate the legal segregation and appropriation of labour-power necessary for the self-augmentation and spatial organization of capital - particularly in peripheral economies where legal constraints are weaker and where the traditional 'limits' of capital can be superseded through barbarism. This reflects the paradoxical decommodification of capitalist wage labour in corporate globalization, a politically regressive shift that undermines the formal contractual relation of free exchange between capital and labour as a marketable commodity by introducing extra-pecuniary systems of coercion to manage capitalist production in legally demarcated accumulation sites (Westra 2010). It also reflects the totalitarian organization of subjects in zones of legal uncertainty where statebased juridical sovereignty 'no longer orders forms of life and juridical rules in a determinate place but, instead, contains at its very centre a dislocating localization that exceeds it and into which every form of life and every norm can be virtually taken' (Agamben 1998: 175).

\section{Networks of transnational power}

Global governance is thus a means for embedding the asymmetric private power of transnational capital in nonmarket institutions in an integrated global economy where national economies are increasingly conjoined by intensified flows of trade and investment. The endurance of 'old world' politics in a globally integrated economy should not blind us to the expansion and consolidation of transnational corporate power through a range of formal and informal organizations connecting corporate-state elites within and between legal jurisdictions, as a result of which the future of global capitalism is partially independent of its formal sanction by states. In effect, global governance is a consequence of the legal vulnerability of a transnational capitalist class whose financial interests are at variance with those of states, and whose global political power cannot be validated democratically.

In Marxian IPE global governance is understood as functional to but in tension with globalization. Lenin emphasized a connection between transnational organizations and the dynamics of rivalry between European empires for control over territory and markets. He maintained a realist perspective, believing that international institutions represented the temporary and inherently unstable arrangements reached by imperialist powers engaged in an endless struggle to repartition the world among themselves' (Callinicos 2002: 
252). Kautsky (1927), on the other hand, argued that while relentless colonial conquest had operated unchecked until 1914, it was not impossible that finance capital might eventually realize that 'this way of trying to increase profits endangers its entire capital and that it would be more profitable to shift to an ultraimperialism, an international cartelization of the finance capitalists of all countries' (Kautsky 1927: 292-93).

These divergent perspectives are reconciled in the present epoch in the form of a transnational capitalist class whose transnational power derives not only from influence in state legislatures, but from the principle of absentee ownership that sustains dominant capital and enables predatory corporations to sabotage local economies of production and consumption. While Lenin rejected Kautsky's view that competing capitals would 'fuse' into a global monopoly that transcended imperial states (siding instead with Bukharin (1917), who predicted the contradictory development of capitalism in a world of nation-states), the state-centric logic of US hegemony after 1945 has given way to a more geocentric system of transnational class power which operates through informal and formal institutional structures of global governance, reflecting the embedded power of a differentiated class of global investors, financiers and international civil servants who collectively oversee an unevenly integrated global economy that has clearly evolved beyond the capacity of the US to manage through statecraft.

Poulantzas (1975) was correct to argue that a US-centric international economy depended on the reproduction of relations of domination operating in the hegemonic power in metropolitan and semi-peripheral economies, but only if we are also prepared to revise the notion of competing national capitals can we observe the actual divergence of transnational corporate capital from the interests of sovereign states in the present period - a phenomenon Poulantzas, in his defence, could not have foreseen. Poulantzas rejected the deceptively neutral ideology of globalization not because he failed to identify the internationalization of capitalist social relations, but because any interpretation of internationalization based on the idea of 'global integration' is misleading as it conceals the real determination of uneven and combined development in the asymmetric relations between the capitalist core and periphery, and the continued relevance of the national state for the defence and hegemonic articulation of local/regional capitalist interests. The hegemonic ideology of globalization represents a 'spatialized abstraction', an 'abstract process whose uneven development would be simply the "dross" of its concretization into social formations' (Poulantzas 1975: 49-50).

Transnational capital is concentrated in the US, EU and globally significant capital markets in Asia, Latin America and South Africa. As Sklair (2001), Robinson (2004b) and Carroll (2010) argue, the power bloc in national capitals is increasingly composed of factions that, by virtue of their own relative exposure to the transnationalization of capital (and US financial capital in particular), come to reflect at different levels of intensity the interests of non-national capitalist interests. In neoliberal global capitalism, there 
is no absolute dividing line between those oriented towards foreign capital and those who champion domestically owned industrial and commercial interests. Networks of capitalist power are heterogeneous and the national/ transnational divide cuts across rival capitalist interests - in part due to the involvement of the state in fractional reserve banking as a means for stabilizing overextended credit infrastructures and maintaining dominant capital against market forces and deflationary pressures in the economy. This is not simply a result of insider rent seeking in systemically relevant corporate financial institutions, but a consequence of the fact that fiat monetary systems are based on continuous market intervention, in which decisions on monetary policy are the result of 'administrative decisions not of market forces, and in which the banks and large parts of the financial industry cannot be free enterprises but must end up under the tutelage of the state' (Schlichter 2011: 239). In extreme circumstances, a domestic bourgeoisie may challenge the power of transnational capital and ally itself to popular classes in defence of 'sovereign' interests - for example the decision by Cristina Fernández de Kirchner to strip the Spanish corporation Repsol of its controlling stake in Argentina's oil industry in 2012. However, it is more likely that a mutuality of interests between national and transnational capitalists will induce a form of solidarity that conceals the differentiated interests of rival fractions of capital in the ruling power bloc.

Sklair (2001) notes that the transnational capitalist class comprises multiple elements and is constituted through a wide range of transnational practices that 'transect' borders, involving four fractions of capital, namely transnational corporate executives, politicians and international civil servants, global professionals (lawyers, lobbyists, economists, accountants, management consultants, etc.), and consumer elites. Although closely linked to the dominant narrative of consumerism (Carroll \& Carson 2006: 52), this heterogeneous grouping is too variegated to constitute a formally unified class for itself, and thus co-exists adjacent to national corporate and political elites who maintain more limited geospatial and commercial horizons.

Nodal intersections of transnational financial networks are located in Europe and North America, but as accumulation becomes transnational, this is leading to a greater geographical diffusion of corporate power. Despite the influence of elite policy gatherings such as the World Economic Forum or Bilderberg, the transnational capitalist class 'exists neither as a free-standing entity (it is deeply embedded in national business communities) nor as a homogeneous collectivity' (Carroll 2010: 228). Such gatherings reflect the accessibility of national-state managers to the lobbying power of corporations and transnational think tanks which seek to influence the careers of future leaders and the formation of international economic legal structures to facilitate corporation trade and investment, such as the TTIP deal discussed in Chapter 3 (Skelton 2014).

For Robinson, on the other hand, this transnational class may not be a unified or homogeneous group but is still a class in and for itself: as a 
cosmopolitan elite it is symptomatic of globalization, aware of its globality and geopolitical agency as states are "transcended by transnational social forces and institutions grounded in the global system rather than the interstate system' (Robinson 2004a: 56). Robinson distinguishes four uses of the term hegemony, namely domination, leadership, leadership within historic blocs, and multilateral consensus (cf. Worth 2009). The class hegemony of the global capitalist elite requires us to 'abandon outdated and restrictive statecentric conceptions of hegemony to a geocentric perspective' (Robinson 2004a: 54-55). Whereas Poulantzas denied that internationalization leads to integration, for Robinson 'globalization is the basis for the emergence of a single global society marked by transnational political and cultural processes and the global integration of social life' (Robinson 2004b: 9). Whereas internationalization implies a purely quantitative extension of 'intranational' commerce, transnationalization indicates the point at which

national capitals fuse with other internationalizing national capitals in a process of cross-border interpenetration that disembeds them from their nations and locates them in a new supranational space opening up under the global economy [... N]ew forms of organizing globalized production are important because [...] they contribute to the development of worldwide networks that link local capitalists to one another and generate an identity of objective interests and of subjective outlooks among these capitalists around a process of global (as opposed to local) accumulation. Therefore they function as integrative mechanisms in the formation of the TCC and act to shift the locus of class formation from national to emergent transnational space.

(Robinson 2004a: 62)

The reproduction of the transnational capitalist class is closely linked to the cycle Marx termed the 'circuit of capital', namely the conversion of money into capital and through transnational production into greater quantities of money.

At the centre of this circuit of capital is the financial core of the transnational capitalist class - an interlocking global network of 160 directors of financialized corporations who collectively manage \$25 trillion of funds invested in almost every country of the world (Phillips \& Osborne 2013). This elite stratum has acquired transnational hegemony through the 'supersession of narrow economic interests by a more universal social vision or ideology and the concrete coordination of the interests of other groups [...] in the process of securing their participation in this social vision' (Robinson 2004b: 76). The promotion of this ideology is the task of international policy networks which coordinate international monetary and financial regulation through transnational forums for elite representation and consensus formation (Coen \& Grant 2001; Plehwe \& Halpen 2006). Viewed geocentrically, 
these networks constitute an interorganizational field which transcends nationality: superimposed onto the existing framework of corporate power this interorganizational field 'pulls the directorates of the world's major corporations much closer together, and collaterally integrates the lifeworld of the global corporate elite' (Carroll \& Carson 2006: 66). It links clusters of intercorporate strategic power and its broad class interests contradict those of Western consumers whose earning power is in decline, as it is recognized that to make Western economies competitive again 'would require a long-term drop in labor costs and the standard of living to the level of many poor nations, with a high risk of social upheaval that would imperil corporate power and its elites' (Suarez-Villa 2012: 26). Led by the Anglosphere, transnational financial capital is deracinated, its functionaries occupying a rarefied global space supported by interlocking corporate directorships and other mechanisms of global economic integration which link local capitalists to one another and generate an identity of objective interests and subjective outlook among these capitalists around a process of global (as opposed to local) accumulation' (Robinson 2004b: 51).

Yet capitalist sovereignty cannot be viewed exclusively in terms of the dominant market power of a transnational oligarchy separated from territorial constraints - as if transnational power were merely a functional equivalent for transcendent political authority, or as if state actors (which acquire political control by containing time within domesticated spatial contexts) no longer existed. As the subject of globalization, whose single goal is value augmentation, the reproduction and expansion of the value form is contingent on subjectification - on the production of really existing human subjects as an objective personification of economic categories (commodified labour-power, unfree labour, consumer, etc.) who not only respond to the economic discipline of the market, but positively identify with the 'cultural and ideological attractions of a particular world order' (Germain 2011: 79; Overbeek 2013: 169).

The transnational hegemony of capital is realized not simply through territorial or extra-territorial juridical power but in the immanent disciplinary logic of corporate social organization as an economic mode of government that shapes human conduct through the production of optimal economic behaviour and the production of intangible commodities linked to the 'grand scheme of neoliberal social engineering' (Suarez-Villa 2012; Barkan 2013). Capitalist sovereignty is neither a global tyranny nor a new imperialism, as anti-corporate activists maintain, but a global apparatus of capture facilitating the predatory enclosure and incorporation of human labour-power, territory and natural resources for the exclusive use of capital, whether the spatiotemporal context of incorporation is national, regional or global. Central to this is the disciplinary power of financial capital in a posthegemonic global growth system which is no longer subject to the will of an imperial state hegemon, but can neither be administered by a world state with multilateral legitimacy. 


\section{The regulatory form of the global commodity production system}

Analysing the implications of transnational neoliberalism for the reconstitution of world order, Vestergaard asks whether power exercised through global governance is more diffused and dispersed, or whether neoliberalism has intensified authority and control, constraining rather than enabling freedom. His answer is unambiguous: 'Never have market economies seen intervention in so manifold ways [...] Never before have predominant modes of global economic governance taken our notion of what a market economy is so far from a neoliberal ideal of "spontaneous order" (Vestergaard 2012: 172). To illustrate his point, he examines efforts by the IMF to strengthen the financial architecture of the global economy after the Asian financial crisis of 1997-98, an event that routinized 'positive' economic surveillance in addition to the 'negative' monitoring of states in balance-of-payments crisis already required by IMF structural adjustment programmes (SAPs). After the crisis economic surveillance was considered appropriate not only for economies in crisis but as a routinized method for disciplining and 'visibilizing' all economies, 'in the best interest of the "proper functioning" of individual economies as well as of the international financial system as such' (ibid.: 187). The regime of generalized economic surveillance is no longer concerned to differentiate (and isolate) failing from healthy economies; the emphasis, rather, is on the creation of techniques to "render possible the meticulous control of the operations of the economy, a calculated manipulation of its elements, its organization and regulation' (ibid.: 189).

As Ahrne and Brunsson (2006: 80-82) argue, standardization is key to the production of world order, which in its 'pure form means the production of rules without the support of any other organizational element [...] The present degree of global order would not have been achieved without standards'. The question is, however, for whom is this generalized economic surveillance and visibilization carried out? For Vestergaard, the initiative has its origins in the Financial Stability Forum created by the G7 in 1998 to identify standards for future global economic governance - a body chaired by Hans Tietmeyer, although other intergovernmental organizations and regulatory bodies were already involved in agenda setting and norm setting in relation to fiscal policy, banking supervision and market integrity (Vestergaard 2012: 190). In what follows, we clarify this issue, interrogating the role of financial capital in the intensification of global governance through the IMF and G20 - not simply to enforce economic discipline for the benefit of transnational investors, but as a totalizing system of controls to standardize, legitimize and deterritorialize financial decision making. Global economic governance is not an option, but a response to market failure - that is, to the logical impossibility of capitalist self-regulation in a period of intensified accumulation and systemic risk and as an alternative to deglobalization and market anarchy. 'Transnational constitutionalism' is a means to enforce neoliberal orthodoxy through intergovernmental institutions, although such efforts may be 
hampered by the tendency of states to resist the pressures and costs of compliance with constitutionalization (cf. Dierckxsens 2000).

Global economic surveillance was intensified after the Asian financial crisis, but has assumed more complex forms in the rush to stabilize the international monetary system since 2008. The logic of intensified surveillance after 1998 and 2008 is identical, however: namely, to routinize micromanagement of national economies, both rule complying and deviant. Yet a distinction must be drawn between these two moments in the evolution of corporate synarchy: whereas the intensification of surveillance initiated by the G7 in 1998 was aimed at establishing a 're-engineered western-centrism' by stabilizing Anglo-American financial power under the auspices of the IMF (Willke \& Willke 2012: 121; Vestergaard 2012; Stiglitz 2002; Chwieroth 2010), the geoeconomic logic of global governance after the 2008 crisis - symbolized by the international response to the fiscal instability of the eurozone - suggests that Western economies are also facing increased surveillance and micromanagement due to persistent structural rigidities, unmanageable debt, and balance-of-payments problems. This is one reason for the elevation of the G20 in 2009 to an intergovernmental forum aligned closely with the IMF for managing global currency imbalances based on the convening power of systemically important economies.

Within the G20, the concentrated authority of world leaders is separate from the routine functioning of existing institutions of global governance (Rothkopf 2009), while the task of managing the international financial system is farmed out to a revitalized IMF, which stands at the apex of a global financial architecture functioning as the 'last lender of last resort' (Rickards 2014: 202). Yet for advocates of global governance, the G20 is unlikely to achieve a stable or enduring form as a 'global steering committee' unless or until advanced economies agree to submit to multilateral decision making (based potentially on majority voting) and governance reform within the IMF itself, by rebalancing voting rights and endowing the Fund with greater political capital to increase its effectiveness as a forum for 'multilateral solution finding' (Lombardi \& Woods 2008: 733). Although constrained by the power of the US Federal Reserve, one of the main achievements of the G20 in 2009 was the creation of a new SDR facility at the IMF to combat the global liquidity shortage caused by declining credit and declining asset prices. After the financial crisis, the IMF more than doubled its SDR leveraged lending capacity to $\$ 580$ billion ( $\$ 750$ billion by 2014), based on 'loans' by IMF members to the organization, and while such figures fall far short of the market capitalization required for a new global reserve currency, the SDR has emerged as a potential alternative to the dollar as a means to stabilize markets in the next global crisis - an unaccountable and opaque mechanism 'permitting global monetary elites to solve sovereign debt problems using an inflationary medium, which in turn allows individual governments to deny political responsibility' (Rickards 2014: 207). 
Yet the G20 is unlikely to fulfil its mandate as a 'global steering committee', 'world cabinet' or 'informal consultative mechanism' presiding over a complex and uneven global economy unless it overcomes the contradiction between intergovernmentalism and supranationalism in the collective governance of interdependent public goods - a contradiction that makes the global financial steering of the G20 appear rather as a 'macrocosm' of the regional European Stability Mechanism created by the European Council in 2012 to safeguard financial instability in the eurozone (Wouters \& Ramapoulos 2012). Despite lacking formal democratic legitimacy, a committee of G20 finance ministers and bankers forced through agreements in 2009 in response to an 'overriding need to act', aided by the G20's informal structure, which 'allowed the necessary flexibility and adaptation for a swift response' (Subacchi \& Pickford 2011: 5); however, the initial 'spirit of the G20' quickly waned, revealing divergent policy agendas between coalitions of states which replicate existing divisions at the UN. Yet the main alternatives to multilateralism are fragmented protectionism and financial regionalism (Willke \& Willke 2012), where organizations of geographically contiguous states or free trade agreements (FTAs) manage their own financial regulation in competition or cooperation with other regional blocs - for example, the complex and overlapping trade agreements that bind member states of Asia-Pacific Economic Cooperation (APEC) and the Association of Southeast Asian Nations (ASEAN), which are set to become still more complex if the TPP is ratified.

At present, the political organization of global economic governance is still distinguished by an 'Anglo-American cultural footprint and by a transatlantic organizational bias', and continues to reflect the 'hegemonic project of transatlantic civil society' (Friedrichs 2004). Intergovernmental organizations like the IMF and World Bank cannot afford to ignore their most powerful members who retain the option of acting unilaterally and/or defecting from multilateral commitments if they perceive their own relative gains will be harmed, because powerful states with 'attractive outside options cannot commit to abide by disadvantageous rules when their preferences are intense' (Stone 2011: 1). However, if Western economies continue to guard their 'leadership rights' jealously and intergovernmental institutions remain too closely identified with Western interests, they will lose their legitimacy among emerging economies in a posthegemonic global economy which are increasingly less tolerant of Western leadership and eager to develop counterhegemonic financial institutions to rival Western leadership of the global economy.

To understand the changing dynamics of global governance and financial surveillance, it is essential to examine the organization of corporate interest representation that drives the institutionalization of capitalist sovereignty through the standardization, legitimation and deterritorialization of economic and financial decision making. In Chapter 1 it was suggested that while capitalism has its origins in relations of domination established by European empires in the early modern period, the political logic of globalization lies not in imperialism but in the diffuse articulation of corporate power through 
geocentric structures of transnational co-governance based on surveillance and visibilization which escape traditional categories and formulations of juridical sovereignty in the trend towards synarchy.

The point of synarchy is not that it reproduces transcendent sovereignty, nor that it destroys its constituent demoi through coercive homogenization (Chryssochoou 2009), but that it depends on the standardized replication of legal norms and rules among sub-units: states, regions, zones or other spatial constellations created by globalization which adapt to and assimilate mutually reinforcing codes of collective economic existence under the general axiomatic of capital. For this reason the emergent logic of synarchy is consistent with contemporary economic techniques of governance rather than traditional models of political domination and control which depend on the threat or application of force. Although the collectively constituted logic of synarchy exists alongside the traditional conflictual dynamics of geopolitics, this subjectifying mode of governance acquires profound significance in contemporary capitalism because the scope of economic surveillance is potentially intrusive and far reaching: in global capitalism, argues Bogard, the logic of surveillance is smoothing - that is, its essential purpose is to 'destratify desire and the subject, to multiply channels of affect and promote the emergence of hybrid subjects, to free information from its connections to signification and truth, and to virtualize relations of power, all within the axiomatic of capital' (Bogard 2006: 76). In this sense, capitalist sovereignty is projected and diffused in the postsovereign global order through a system of intergovernmental institutions, pre-eminent among which is the IMF - the central pillar of the global financial system that supervises international payments and international exchange rates and which has expanded from shortterm stabilization planning to long-term structural adjustment of economies to meet the needs of global corporate capital.

To ask whose interests the IMF serves, one must begin with its shareholders: the principal capitalist economies whose voting rights reflect their economic weight in the international monetary system and ascribed status in the international hierarchy. However, the progenitors of IMF policy are not sovereign governments but financial corporations whose lending practices create indebtedness, and whose solution to indebtedness is to coerce governments to promote liquidity and remove legal constraints on the mobility of transnational capital through capital account liberalization - a policy once considered an efficient means for channelling investment from capital-abundant to capital-scarce countries where expected returns are high, but which is now understood to create destabilizing speculative 'hot' capital flows that increase the occurrence of financial crises with few gains for investment or output (cf. Henry 2003; Stiglitz 2002).

In fact, the role of the organization is more complex than this allows, for in pushing structural adjustment on recipient states, the goal of the IMF has consistently been to bridge the contradiction between sovereign fiscal and monetary policy and transnational market rationality. As Peet argues, given 
its origins in a state-centred world system, the IMF has attempted to "synthesize aspects of Keynesian regulation with neoliberal demands for deregulation. Resolution of this contradiction has required governance institutions to oversee the deregulation of national economies' (Peet 2009: 117). This policy, he adds, has 'involved a shift upwards in the locus of power to the global institutional level, within geoeconomic power relations that maintained US control' (ibid.).

Peet highlights the close proximity of the IMF to corporate interest organizations that shape global monetary policy, in particular lobbying organizations representing banks whose primary consideration is the security of their investments. The IMF serves financial corporations by (i) maintaining liquidity, (ii) providing intelligence on the real condition of debtor economies through surveillance, and (iii) coordinating international financial policy and stabilizing markets. However, the principal concern of global capital is the transformation of short-term debt into profitable investment:

Bankers see any regulation that restricts capital flows as an obstacle to their business. Their ultimate aim is to keep capital flowing as much as possible. This is why they are not concerned with the immediate repayment of debts as much as with potential repayment in the future. They welcome any suggestion for an increase in lending as long as there is some guarantee that part of their loans will be repaid in the future [...] Some analysts see rescheduling as 'near default', or 'default by attrition' that is, default in everything but name. A good investment banker, however, knows that the transformation of short-term into long-term debt is a transformation of commercial loans into investment loans, and of a commercial client into a chronic borrower.

(Peet 2009: 121)

Yet the influence of the global banking community is subtly qualified by Chwieroth (2010), who argues that the bureaucracy of the IMF was itself already intellectually responsive to neoliberal ideology in its professional working culture, and officials were already advocating the abolition of capital controls before Michel Camdessus (director in the 1990s) campaigned for policy reorientation. 'Without firm directives or formal rules [...] the staff were provided with significant autonomy to develop their approach independently'. This relative autonomy, he adds, 'permitted the staff members to rely on their own judgement and initiative to determine whether liberalization should be encouraged informally in a given case' (ibid.: 159).

This reflects the extent to which transnational institutions like the IMF or Bank for International Settlements (BIS) acquire their own functional logic as norm entrepreneurs, particularly where there is disagreement among principals within the intergovernmental structures that influence policy formation - as is the case with the IMF and G20. Yet the zealous devotion of IMF officials to 'capital freedom' has survived successive crises not only because its members 
espouse neoclassical orthodoxy, but because this technocratic elite operates among a rarefied, self-reinforcing class of chief executives, fund managers, lawyers and high-net-worth individuals whose normative outlook is preformed and predetermined by ideological receptivity towards liberalization - even if (paradoxically) non-state actors like the IMF actually combine Keynesian macroeconomic management policies with neoliberalism, defending a form of financial economics that assumes a "world where entrepreneurs are redundant and financial markets have superior knowledge of customer needs and the potential of resources - in other words a world of financial socialism' (Ehret 2012: 5). The reasons for this must be traced back to the leverage exercised by dominant capital over national and transnational regulatory institutions, a form of private political power that has successfully undermined strong formal regulation (hard rules rather than soft law) in the global financial system in favour of informal interventions to correct market failure based on the transfer of burden sharing to public authorities.

The paradoxical role of the IMF as a international financial institution and arm of the global investment community can be understood further if we examine more closely the ways in which the theory and practice of transnational financial governance diverge. To illustrate this point, Buckley (2012) examines how the IMF consistently acts in contravention of market principles by rewarding banks and elite investors for market failure. The IMF, he observes, does this by

selectively applying market principles and disciplines. The market is allowed to operate unimpeded when it delivers profits to international banks and the elites in developing countries, and its operation is interfered with, grossly, when market forces impose massive losses on the banks and/or the developing country elites.

(Buckley 2012: 43)

This is exemplified by the IMF's demand in 1998 that Indonesia take on the financial obligations of its banking sector to foreign lenders, which led to the widespread impoverishment of the Indonesian population, who were forced to assume the burden of placating foreign lenders by refinancing the nation's banking sector - a phenomenon repeated in the advanced economies after the global financial crisis. The IMF applies market discipline rigidly, yet simultaneously fails to support efficient allocation when it matters: there is no paradox here, however, for the IMF is 'consistent not in its commitment to the allocative efficiency of markets, but in its commitment to furthering the interests of the international commercial banks'. The result is that the Fund 'turns its back on market principles and engineers massive interventions in the market, and at other times when it suits the international commercial banks and elites in debtor countries the IMF applies market principles with extreme rigour' (Buckley 2012: 47). This raises questions about the universalisability of global governance processes, including legal certainty and moral hazard 
prevention which are essential for the creation of a stable environment for 'efficient' financial markets. Yet as Kaufmann and Weber (2012) note, if these issues are critically examined in the light of recent developments, it becomes clear that legal certainty and moral hazard are essentially irrelevant where the objects of surveillance are systemically relevant institutions that are not allowed to fail. In this respect it is increasingly clear that the political economy of world order is only partially defined by market forces: within this international economic system dominant financial capital thrives because the national and transnational institutions that regulate trade and investment (and facilitate the creation of maximum shareholder value by negating competing criteria of economic rationality) are managed by officials acting for corporate power interests. The global economy is 'skewed to the interests of global corporations, it is oligopolistic, competition is often constrained and the market regulations are aimed at controlling national governments as much as at regulating MNCs [multinational corporations]' (Wilks 2013: 150).

For Wilks, the sovereignty of the market is organized around two operative principles that exert the same level of force as limited liability - the basic principle of corporate power. The first is national treatment, which prohibits preferential treatment by governments of domestic producers but does not rule out more favourable terms of trade with foreign multinationals. The second is most favoured nation status (MFN), which requires states to negotiate terms of trade with all trading partners equivalent to those of their closest partners, and which also ensures foreign multinationals are treated equally, regardless of their nation of origin (Wilks 2013: 151). These principles, argues Wilks, 'have becomes part of the DNA of international agencies and networks which regulate the global economy - the IMF, WTO, World Bank, the BIS, G7/8 (or now G20) and the OECD' (ibid.).

Yet despite the power of this global regulatory framework, it is limited by an absence of constitutional rules for regulating investment and competition because Western powers have acted to prevent their formulation and codification, preferring to rely instead on 'soft law' to police corporate governance. Here it is important to note how dimensions of global decision making escape the typical 'global-national' binary of political sociology as state structures 'expand and flow along with the globalization of other social institutions and social relationships', as a consequence of which 'some aspects of the state have been thoroughly transnationalized, while for others the transnational linkages are underdeveloped' (Major 2013: 33-4).

The Financial Stability Board created at the G20 London summit in April 2009 is a global regulatory authority tasked with coordinating the work of national financial authorities and norm-setting regimes, which brings together officials responsible for financial stability, financial institutions, sector-specific international regulatory bodies and central bankers in a new international regulatory regime to stabilize the global monetary system and intensify economic surveillance (Cleaver 2013: 196). Yet the new international financial architecture not only insulates monetary authorities from popular-democratic 
forces, but strengthens ties between private economic actors and public financial institutions, dissolving the distinction between private economic power and public authority. This can be seen in the politics of austerity as a policy response to the sovereign debt crisis in the West, which has resulted in new combinations of private and public power like the European Stability Mechanism which aggregates funds from private banks that are guaranteed by central banks: 'This relationship between private and public finance', Major argues, is increasingly 'hand-in-glove [...] precisely the opposite outcome that Keynes had in mind when he envisioned the role that national monetary authorities would play in regulating and stabilizing the international monetary order' (Major 2013: 43). Global monetary authority, he concludes, has become the 'gateway through which national governments seeking financial assistance must pass'. Largely invisible to the public, however, it is this 'financial dependency on a transnationalized monetary authority that fills a critical part of the story of the resiliency of austerity that so often gets missed by a sociology of globalization defined by a national-global dualism' (ibid.).

Kirton suggests that the de facto legitimation of the G20 as a synarchic model of global governance reflects the underlying instability of a global economy characterized by uneven development, a system increasingly vulnerable to existential threats which - as he puts it - can 'arise anywhere and flow fast and freely to exert their unintended and uncontrolled destruction on even the most powerful states' (Kirton 2013: 381). For neoliberal institutionalists, the lesson of the global financial crisis and the crisis of US hegemony is the inevitable 'messiness' of attempts to achieve multilateralism - a problem identified by none other than the head of the Council on Foreign Relations, Richard Haass, which promotes international collaboration under US leadership (Alexandroff 2010).

For some, G20 summits lack the power to constitute a global political authority (Bremmer 2012); for others, the 'Gx' process does indeed have the potential to become more influential and central to the governance of the world system - to become, in effect, the 'inner cabinet of the global polity, compactly including all globally oriented countries, embracing the full public policy agenda, engaging the multilateral international bureaucracies, and most departments of national governments' (Kirton, cited in Alexandroff 2010: 3). On the other hand, as Alexandroff observes, such idealism runs up against the pragmatism of states which still see international summitry as a vehicle for driving those dimensions of supranational co-governance that advance their own sovereign political interests - particularly in relation to exchange rates - or which use the Leaders' Summit to isolate states that resist Western geopolitical interests - a tendency on display in Brisbane in November 2014. Yet, while governments cope with the geopolitical contradiction between intergovernmentalism and supranationalism, and the democracy deficit of compliance with unelected transnational institutions, the real question for developed and emerging economies is not institutional legitimacy, but 
how sovereign states can operate in and through international regimes to negotiate optimal terms with financial capital over the regulation of global markets to support the market share and market capitalization of transnational corporate networks which constitute a dominant component of their own economic power and geopolitical influence.

\section{Conclusion}

The intensification of transnational governance in the last two decades testifies to the equalizing vulnerability created by neoliberalism as a transnationally constituted global social order in which states must continually anticipate existential threats ('spill-overs') and show systemic relevance or face oblivion. It also suggests that global economic and financial integration tends to proceed ahead of supporting political governance (Berglof 2012), and that crisis management and institutional innovation are likely to remain features of globalization in periods of turbulence. Adaptation to the new international financial architecture is complicated for Western states by the increasing power of non-Western states in an integrated global economy where emerging market economies are demanding more influence in transnational decision making, and where new IFIs like China's Asian Infrastructure Investment Bank (AIIB) are emerging as rivals to the western-led institutions created at Bretton Woods in 1944 (Kirk 2015).

From an institutionalist perspective, financially weakened governments in the West must negotiate a delicate balance between national and transnational priorities: in recognition of the increasing importance of emerging economies, the established hierarchy of Western capitalist states must either yield greater influence within organizations like the G20 and IMF to China, India, Brazil and other middle-level economies where FDI is now concentrated (and thus accept revisionist demands for an adjustment to their modus operandi and strategic direction in return for larger financial contributions), or pursue more aggressive forms of statecraft to weaken their financial stability, intensify competition for control over resources, and attempt (overtly or covertly) to control the rate at which rising economies can grow.

From a critical perspective, however, this dilemma reflects the contradiction between the imperialism and the posthegemonic dynamics of global capitalism, where the capacity of sovereign states to activate power resources and obtain desired effects is greatly determined by their relative position within corporate networks and fluctuations in international flows of capital. On this view, globalization has not only stimulated demands for global monetary coordination and economic surveillance through the state form of transnational capital, but has also, by stimulating growth in emerging market economies, exposed the essential anachronism of imperial state hegemony as a model of asymmetric domination bequeathed by the decline of the European nation-state system. The financial leadership role of Western powers in the primary institutions of global economic governance is still tolerated by non- 
Western powers in return for recognition of their own increasing systemic relevance, but the horizon for global corporate policymaking is shifting beyond the declining economies of the West that triggered the global financial crisis, towards multiple growth poles centred on manufacturing centres forecast to play a pivotal role in global recovery and transnational corporate strategy in the twenty-first century. It seems clear that both rising economic powers like China and India, and reviving powers like Russia will adapt to Western norms of governance in the short term, but will eventually seek to revise the existing structure of global governance to support their own geopolitical aspirations and regional financial interests. The role of the G20 was intensified to broaden the legitimacy of global governance in the wake of the financial crisis, but it cannot conceal the disparity of interests between status quo powers that remain invested in a US-centric order and revisionist powers that are already preparing for a multi-currency reserve system in a posthegemonic international system.

\section{Notes}

1 See Langmore and Fitzgerald (2012), who discuss the similar idea of a 'Tobin tax' as a means for funding the transnational institutions required for strengthening global economic governance.

2 Discussing the need for reform, General Counsel and Director of the Legal Department of the IMF Sean Hagan observed that there is increasing concern that the 'failure by the Fund to take meaningful action to address perceived inequities and inefficiencies in the decision-making process could undermine its legitimacy and effectiveness' (Hagan 2010: 50). The global financial crisis created momentum for a change in voting rights, with emerging market executive directors calling for GDP statistics to be measured not in absolute dollar terms but in accordance with purchasing price parity, reflecting economic reality more closely by providing the "best - and most dynamic - way of measuring the relative volume of goods and services produced by economies' (ibid.).

3 It is important to distinguish between the normative legitimacy of international institutions and their de facto acceptance as appropriate and "worthy of being obeyed' (Keohane 2002: 57). In practice these two dimensions overlap, because an institution's multilateral legitimacy is dependent on whether it is both effective and inclusive. In an ideal world, international institutions would be both effective and inclusive, but in the real world great power politics intrudes and imposes limits on multilateralism.

4 See Dugin (2012) who, from a reactionary conservative perspective, argues that neoliberalism threatens to 'drown the world in a universal sameness'. Like Krebs, Dugin offers a purely cultural critique of neoliberalism devoid of theoretical analysis of the links between ideology and the economic relations of 'post-political' society.

5 The value of the Greek economy fell from US\$341 billion in 2009 to $\$ 242$ billion in 2014 - a decline of 44 per cent (data from www.tradingeconomics.com). 


\section{The crisis of Western economic power}

\section{Introduction}

In this chapter we examine the crisis of Western economic leadership within the structural development of global capitalism. It was suggested in Chapter 3 that the crisis of Western financial capitalism indicates not the end of capitalism as an historically specific mode of power that accelerates yet (periodically) destroys human productivity, but its reorganization and reconstitution in a totalizing form through the state form of transnational capital - that is, through an intensification of global economic integration in which finance plays an increasing role in the generation of value. In this respect, at least, expectations of radical change in the wake of the global financial crisis have been disappointed - not just by the relative ease with which central banks have restabilized economies through unprecedented injections of liquidity (reflating asset bubbles in the equity markets while transferring private corporate debt to the public), but by the failure of Western voters to question the hegemonic discourse of fiscal consolidation (austerity) propagated by corporate media. On the one hand there is wilful delusion among a naïve Western public that current equity values are sustainable - as Chang (2014) argues, these record asset values do not reflect economic fundamentals and are only being sustained by the abnormally high levels of liquidity created by quantitative easing, which can only be withdrawn at the risk of accelerating deflation. On the other hand, there is self-delusion on the left about returning to 'stable' capitalism, indicating a lack of insight into the fundamental contradictions of commodity capitalism that presuppose cycles of accumulation and deleveraging as profit rates rise or decline, and as structural inefficiencies in neoliberal corporate capitalism intensify. On the moderate left, argues Heinrich, "there still exists the belief that, with the "correct" economic policies, full employment can be conjured up; "unchained" capitalism must simply be properly regulated again' (Heinrich 2007: 1). On the radical left, however, there is a widespread and unjustified belief that we are heading for a 'final crisis' - 'as if it were ever the purpose of capitalism to spread full employment and welfare among the people. Crisis and unemployment are in no way a sign of capitalist decline; they are capitalist normality' (ibid., emphasis added). 
This is not to suggest the crisis changed nothing - as will become clear, it indicated the potential limits of accumulating value though financial innovation and technology and the dangers of technology for capitalist social relations only that its political impact has been contained through a condensation of market ideology and authoritarian-populist narratives of identity-driven consumerism which resolve the performative contradiction between subjects as individual consumers and collective producers of nationhood, and which function as 'flanking devices' to marginalize counter-hegemonic anti-capitalist, anti-racist and anti-militarist movements on the left (cf. Woodley 2013). While serious political unrest has occurred in Southern Europe and MENA since 2011, indicating opposition to neoliberal policies and the fragility of pro-Western client elites (Fouskas \& Dimoulas 2013; Hanieh 2013), the crisis has not produced a decisive turning point (in the sense of 'crisis' [Koívelv] as a critical moment of bifurcation), and predictions of revolutionary change have been premature. This has left many on the Left with few other options than to warn of more serious crises to come, as neoliberals rehearse platitudes about a return to growth and the need to 'humanize' capitalist finance (Shiller 2012). ${ }^{1}$

The eclipse of the West is a logical correlate to the resurgence of Asia and the rise of new regional economies that seek to achieve economic growth and geopolitical security through insertion into the global capitalist system. Yet the decline of Western economic hegemony must also be understood in the context of the structural crisis of accumulation haunting capitalism which critical political economists link not only to overcapacity and declining demand but to the inner contradiction of the commodity form which has become more acute with the accelerated development of the money form of capital (Lohoff \& Trenkle 2013). The structural crisis of valorization in Western economies is linked to two key developments in the global economy: financialization and the rise of China as the world's leading exporter whose present expansion remains dependent on Western consumption but whose integration into the capitalist system has internalized within its own domestic economy the overaccumulation crisis haunting the West. However, while China's growth is slowing (Rabinovitch 2014; Roach 2015), and while China faces major political challenges, if the rebalancing of China's economy towards a labour-intensive service sector is successful these are unlikely to delay a shift in the centre of gravity of global capitalism from the West to Asia, negating the violent legacy of Western financial capital in the imperial epoch (Hung 2008). To grasp the structural violence of financial capital it is necessary to reconstruct the historic linkages between Western corporate and security elites in defence of European colonial power, a system of financial and military coercion that sustained Western hegemony up to the 1980s, but which is increasingly challenged by the rise of regional power formations. These linkages incorporated state and non-state actors in a transnational network of financial and military power based on the Anglosphere, supported by local comprador elites in peripheral regions who derive(d) their authority 
and position from proximity to transnational corporations and financial institutions operating within OECD states.

However, an adequate account of capitalist sovereignty must explain not simply the transnationalization of capitalist finance as a causal variable (and its impact on regional markets and local communities), but the inner tendency of capital to develop new social forms while regenerating the identical commodity relations of power rooted in the value form. As self-valorizing value, which produces commodities solely for the sake of production, capital at once creates the conditions for sociopolitical change, yet neutralizes this modernizing impulse by facilitating and intensifying patterns of uneven global development and extreme inequality - a contradictory process that stimulates demands for a synarchic coordination of markets and securitization of investment from corporate actors operating in a global political economy. Yet, however self-correcting this system, the instability of financial capitalism cannot be overcome indefinitely because crisis is a permanent possibility of financial markets in which money is a commodity (Amato \& Fantacci 2012). In other words, crisis is a perpetual feature of financialized capitalism which 'resets' the environment for profitable investment.

Marx's theory of money is a commodity theory of money, where a specific commodity simultaneously plays the role of a universal medium of exchange and store of value because it is itself the product of socially necessary labour. The social function of capitalist money is thus to act as a commodity, the price of which is determined by financial markets, which in turn determine the value of all other commodities, equities and debt-based securities in response to price fluctuations. Finance capital posits no substantive or logical end: its sole goal is to perpetuate itself, delaying ad infinitum the final payment or closure of debt as a relation of power. The perpetuation of debt is its purpose, and finance consistently suppresses the possibility of its own closure by creating new conditions for the further expansion of debt and the production of subjects (individuals, firms, cities, states, etc.), to perform relations of dependence integral to the reproduction of indebtedness, a tendency revealed not only in the growth of private debt among 'libidinally exhausted' consumers, but in the catastrophic First World debt crisis (Stiegler 2010; cf. Pettifor 2006; cf. Lazzarato 2012; Stockhammer 2011).

The political origins of Western economic power lie in the expansion of the debt relation and the coercive appropriation of strategic resources for the reproduction of industrial society in the global North - typically at the expense of industrialization in the global South (Mishra 2013). Western Europe's financial and military power arose in part due to a comparative advantage in violence dating back to the revolution in military affairs between 1500 and 1800 , reflecting important innovations in military production and organization (Morris 2013; Hoffman 2011). ${ }^{2}$

A critical factor in explaining the expansion of financial capitalism is not just the destructive power of Western military forces or the violence employed in extractive industries in colonial economies, however, but the stimulation 
effect of permanent war preparedness in the early twentieth century which not only accelerated the West's comparative advantage in violence but led to a revolution in the organization of public finance and the peacetime adaptation of new forms of deficit spending and monetary expansion to counter the deflationary tendencies of capitalist cycles. The transformation of public finance was achieved principally through inflation, taxation and public borrowing (Strachan 2004), but war itself also afforded an opportunity to reset economies by destroying overcapacity, creating new opportunities for credit, investment and reconstruction. This is exemplified by the second outbreak of total war during the final years of the Great Depression between capitalist states whose aggregate destructive force was enhanced by the mass of idle labour-power that could be translated into unproductive military expenditure. As one historian notes, the Second World War led to 'systematic destruction not merely of armies on the battlefield, but of the industrial capacity of the belligerents and the civilian populations who could place that capacity in motion' (Eaves 2011: 4).

In the extreme case of global deflationary recession, capital facilitates a return to profitability not through higher productivity or innovation as stimuli for 'recovery' - a mythic idea which brackets out the sabotage of communities as a precondition for returning to profitability - but through the destruction of collective wealth in regimes of 'anti-production' and war. Recalling Harvey's (1982: 442) comment that war is the ultimate form of devaluation, Papageorgiou (2013: 39) argues that financial crises and the wars that follow 'perform the function of the negative, purging the mode of production of its momentary excesses and priming a renewed technological base for the return of accumulation'.

In the third and fourth sections of the chapter we examine the approaching decline of Western economic power and the causes of fiscal and monetary instability in the West in the light of research on the present crisis. Our aim is not to recount the events leading up to the collapse of the US subprime mortgage market in 2007 - the subject of an already voluminous literature (Foster \& Magdoff 2009; Ciro 2012; Friedman \& Kraus 2011; Hendrickson 2013; King 2011; Macdonald 2012; Kawamura 2013), but to offer a theoretical account of overaccumulation in a globalizing economy.

As Brenner (2009) argues, the term 'financial crisis' is misleading because it distracts attention from the underlying weakness of capitalist economies since the 1970s, notably the declining rate of return on capital investment and the failure of the rate of profit to recover, which in turn reflect a tendency towards overcapacity in global manufacturing that encouraged financial and nonfinancial corporations to seek alternative lucrative sources of return through financialization. This has led to a massive accumulation of leveraged capital in the form of volatile investment funds ('hot money') in search of high-yield outlets, but while the trigger for the global slump was the collapse of the US housing bubble which sucked in global investment creating huge quantities of toxic debt in the US (Kawamura 2013), the events of 2008 reflect a deeper 
structural crisis of valorization linked to the value form-determined character of capital. The outcome of the crisis was predictable: unemployment, capital flight and bankruptcy led to a 'controlled demolition' of local economies as systemically relevant financial institutions acting through the national and transnational state offered ad hoc solutions to restabilize the financial system, stripping equity from markets, draining national treasuries and, in some cases, 'bailing-in' savings from small depositors and businesses in bankrupt jurisdictions (for example, Cyprus in 2012) to compensate global investors who exploit collapse as an opportunity to 'wipe out competitors, consolidate and centralize bank power and exert an overriding control over the real economy, the institutions of government and the military' (Chossudovsky 2013: 2; cf. Brown 2013). The political economy of debt prioritizes financial gain over productivity, yet however destructive for society, debt deleveraging is seen as 'cathartic' because the restructuring that follows enables 'policies to be adopted which clear the decks, removing subsidies and protection, and freeing up capital from fixed positions. It allows capital to regain mobility, dissolving the spatial and institutional rigidities in which it had become encased' (Gamble 2006: 26).

The actions of corporate financial elites whose venality triggered the global crisis become comprehensible if we recognize that to remain commercially viable banks must integrate increasing sections of the population into the credit/debt nexus of finance - a phenomenon clearly evidenced by the unprecedented growth of subprime lending in the US mortgage industry prior to 2007 (Ivry 2014). Their actions may appear morally reprehensible but must be contextualized by examining the crisis outside the standard framework of methodological individualism favoured by economists to understand the dynamics of accumulation and recession. As we saw in Chapter 3, modern capitalism is a class formation in which private corporate entities govern the individuals and activities within their jurisdiction; however, it is also one in which the power of financial capital may nevertheless be approaching its own asymptotic limits. That is to say, although the capitalist logic of value as equivalence and substitutability underlies the basic functioning of the economy, diminishing market returns as cyclical patterns may be reaching their upper limits, leading to a potential challenge to capitalist finance (Nitzan \& Bichler 2012; cf. Wallerstein 2006b). Far from retreating into irrelevance, the state form of capital has re-emerged as a precondition for managing systemic risk in advanced economies, leading to the monetization of debt (controlled devaluation) and new forms of financial statecraft to undermine rival stores of value (precious metals, commodities) and weaken emerging economies. A hybrid form of economic fascism is emerging - a 'socialism for the investor class' - which will endure if three conditions for the consolidation of transnational corporate power are met, namely: the monetization of debt through expansionary monetary policy; the growth of open-ended geopolitical conflict to neutralize domestic political tensions and drive extractive accumulation in peripheral regions; and investment in the apparatus of state repression and 
surveillance to manage resistance to the corporate appropriation of national incomes.

\section{The logic of Western military and financial power}

The economic power of the West has its origins in the system of financial accumulation and military violence forged by European powers in the eighteenth and nineteenth centuries. European economic development was based on the 'exclusion of the vast majority of the world's population from access to the natural and human resources needed to benefit rather than bear the costs of global industrialization' (Arrighi 2007: 386). It took place under British hegemony, a unique phenomenon in the history of international political-economic organization. Unlike preceding empires,

Britain modelled its post-Waterloo empire on an extremely sophisticated marriage between top bankers and financiers of the City of London, government cabinet ministers, heads of key industrial companies deemed strategic to the national interest, and the heads of the espionage services [...] Because all this was secret, it wielded immense power over credulous and unsuspecting foreign economies. In the Free Trade era after 1846, this covert marriage of private commercial power with government was the secret of British hegemony.

(Engdahl 2004: 8; cf. Van der Pijl 2001; Davis \& Huttenback 1986)

Although Britain's formal empire was destroyed by the impact of the First World War - an epochal event that brought the long nineteenth century to a close and prepared the way for war between Germany, the US and the Soviet Union for global supremacy - the informal system of international finance created under British hegemony endured through a de facto alliance between London and Washington based on tacit agreement to project Anglo-American financial influence in the colonial periphery and Anglo-American control over the new oil-producing regions of the Persian Gulf. The principal goal of British strategy was to rebuff attempts by contender states to challenge its unique role, and to retard German economic growth. Before 1914, this was achieved by undermining Germany's energy security and access to the untapped oil wealth of the collapsing Ottoman Empire; after 1918, it was achieved by undermining the financial stability of the Weimar Republic whose viability as a postimperial state was threatened by unpayable debt. While collaboration between the US and UK ensured the leadership of the Anglosphere in interwar international politics, however, it concealed not only rivalry between financial elites in New York and London for control over capital flows and energy, but the dependence of the UK on American banks whose loans to England and France in the First World War were decisive for Allied victory.

The modern form of capitalist public finance has its origins in the First World War, which saw the expansion of the state form of capital to manage 


\section{The crisis of Western economic power}

the contradictory logic of accumulation in corporate capitalism, the replacement of individuals by public authorities as primary holders of debt, and the costs of financing a war that endured much longer than expected through expansionary monetary policy. As Clarke (1992) observes, the expansion of the state form of capital reflects a constant tendency to develop the productive forces, which in turn reflects the tendency for capital to develop the world market and expand capitalist relations. However, he adds, this tendency to advance productive forces 'without regard to the limit of the market also underlies the tendency to the global overaccumulation and uneven development of capital, as the development of social production confronts the limits of its capitalist form as production for profit' (ibid.: 135). This creates problems for the management of capitalist finance, highlighting not only the class nature of the capitalist state but the specificity of its financial circuit. The relation of the capitalist state to the contradictory logic of overaccumulation, argues Clarke, is mediated by the form of the state:

[While] the subordination of the state to money defines the economic form through which an overaccumulation crisis appears to the state, and sets limits to the powers of the state in response to such a crisis, it does not determine the specific political form of the state, through which the contradictory tendencies of accumulation are mediated politically, nor the specific responses of the state in the face of a crisis. The political form of the state is determined by the class struggle, and most particularly by the struggles of the working class which arise as the working class confronts the subordination of social production to capital as a barrier to its own physical and social reproduction.

(Clarke 1992: 136)

On the other hand, the political management of capitalist state finance reflects the specificity of the financial circuit of the state, for as Davis notes, 'the ability of the state to finance the military, for the expansion of markets abroad and for the discipline of labour at home, must be developed [...] capitalist competition and success at imperialist wars has often been determined by relative fiscal capacity' (Davis 2010a: 413).

The institutionalization of the warfare-welfare state was a subject of intensive research in Marxist political economy after 1945 (Baran 1957; Baran \& Sweezy 1966), and need not be discussed here. What must be addressed is the functional logic of the financial circuit of state in the reproduction schema of the advanced economies in which commodified financial power supported by state power transcends traditional commodity production in the generation of value. For Davis, the financial circuit of the state is a key component in the total reproduction of capital in the advanced economies, although this circuit differs from the general capitalist circuit of capital because there is no absolute expansion of value, because commodities bought by the state are acquired to stabilize and expand the capitalist circuit, and because sovereign 
tax revenues must be adequate to meet the demands of debt servicing although bond auctions enable the state to evade requirements for long-term fiscal stability, utilizing debt instruments to stimulate the economy through the multiplier effect (Davis 2010a: 414-5).

Under normal conditions, this is sustainable because state debt based on governmental taxing authority is a secure asset that sustains macroeconomic stability. In effect, argues Davis, the 'market system can improve in productivity as a consequence of the expansion of the scale of financial circuits, which is a common interest of both the state and private firms' (Davis 2010a: 419). Expanding public debt has thus become a core indispensable feature of capitalist finance highlighting the role of war and war-preparedness as objectives of state policy - less for territorial acquisition than to support the free movement of capital. Under neoliberalism, however, it is not just debt that increases but, paradoxically, the functional centrality of the state form of capital to the reproduction of surplus-value. As Stockhammer notes, this point was noted by Foucault, who observed how neoliberalism departs from classical liberalism because it 'does not aim to liberate markets but rather to create markets, and subordinate government activity under this goal. Markets do not create themselves, if left to their own, but have to be constructed and maintained' (Stockhammer 2011: 241). On the contrary, neoliberalism requires 'permanent and profound state intervention' (ibid.).

The increasing importance of the financial circuit of the capitalist state becomes clear if we examine the legacy of imperial finance in the First World War. Although imperial Britain and France were intolerant of debt - British debts had mushroomed after the Boer War, effectively bankrupting the country, while France was still haunted by the use of irregular forms of finance during the War of the Spanish Succession which undermined its national treasury (Rowlands 2012) - the exigencies of 'total warfare' introduced during the first major international conflict of the industrial age indicate that 'dire financial straits' are not a sufficient reason for states to limit their geopolitical ambitions or back away from conflict in defence of strategic interests (Strachan 2004).

In addition, the financial history of the First World War shows how the lucrative gains obtained from financing the Allied war effort allowed American banks to extend their international influence and capitalize on the massive increase in sovereign debt accrued on both sides of the Atlantic after four years of fighting, leading to a net transfer of funds from Europe to the US which irreversibly altered the balance of transatlantic relations in America's favour. Confident of winning the peace, British hopes of debt forgiveness were dashed at Versailles as it became clear the private liabilities of J.P. Morgan had been transferred to the US Treasury in the war, increasing the functional interdependence of US corporate-state elites. As US debt expanded to unprecedented levels, 'the distinction between Morgan's interests and that of the government became blurred. The US government increasingly made itself [...] a useful instrument for the extension of the new power of New York's international bankers' (Engdahl 2004: 55). 


\section{The crisis of Western economic power}

Hudson (2003) notes that US insistence on repayment of war loans was unprecedented in the history of inter-Allied warfare, and a by-product of this was US refusal to accept exports as a substitute, leading to a huge transfer of gold from Europe to America as payment. This policy ultimately proved disastrous for the interwar economy as the use of repayment schedules and dollar devaluation as weapons undermined hopes for trade normalization and destroyed European hopes for recovery. Roosevelt's belligerence at the 1933 London Conference led to debt repudiation from the Allies which temporarily resolved the intergovernmental debt crisis yet inaugurated a dangerous period of protectionism and imperial regionalism:

It would be false to say that the United States provoked World War II out of malice or out of knowledge of the results of insisting on repayment of its war debts by a world utterly unable to repay them. It is true, however, that no act contributed more to the genesis of World War II than the intolerable burdens the US imposed on its allies of World War I and, through them, on Germany. Every US administration from 1917 through the Roosevelt era employed the strategy of compelling repayment of these war debts, above all by Britain. The effect was to splinter Europe so that the continent was laid open politically as a possible province of the United States.

(Hudson 2003: 113)

The US was also a victim of its own beggar-thy-neighbour policies in the 1930s, unable to recover from the Depression without resorting to military production. The US 'came to recognize that it needed export markets to maintain full employment and prosperity, and that bleeding Europe dry by over-indebting it was counter-productive' (Hudson 2003: 113).

If the First World War established a nexus of interests between financial and military elites in the principal belligerent nations - highlighting the centrality of finance for capitalist power, war-making capacity and domestic security, the Second World War accelerated the unification of corporate-state power through the institutionalization of the 'warfare-welfare' state. The financial and military power of Western economies was further consolidated by the creation of new relations of debt and dependency between Western-led international financial institutions and postcolonial states, through the isolation of the Soviet Union and the assault on communism in Asia, through the violent suppression of workers' movements in semi-peripheral economies (Argentina, Turkey, Greece), and through patronage of client regimes in the global South encouraged to dismantle import-substitution models in favour of export-led growth and infrastructural development financed by World Bank loans (Gunder Frank 1978; Peet 2009; Perkins 2006). Hudson stresses in particular the relevance of Robert McNamara's appointment as president of the World Bank in 1968, reflecting pressure from the US for the Bank to redirect lending operations for the benefit of Western financial institutions 
that see long-term sovereign debt as business investment. The appointment of McNamara, he argues, 'may be viewed as an extension of his authority as strategist of Pax Americana from national to global scope. Having enlarged the Pentagon's role in American society to one of dominance, he was [...] able to lay down explicit social policy conditions to be adopted by applicants for World Bank loans' (Hudson 2003: 197).

Just as Western aid was used to influence the security agenda of client regimes co-opted into the hegemonic discourse of anti-communism, so the resources of the World Bank were now to be mobilized as a 'vehicle for militant US policy abroad', linked to Malthusian demands for population control and controls on fiscal policy (Hudson 2003: 199-201). The focus of lending was export industries as a means to increase foreign exchange reserves and stimulate imports of high-value consumer goods, but this falsely interpreted developing economies as firms "whose cash returns on the use of borrowed funds could be depended to be in excess of the stipulated outflows for debt retirement and interest charges' (ibid.: 207). This led not to increased output of consumer goods for domestic use but to rising imports of finished goods, the cost of which reduced the ability of indebted states to honour financial obligations. Although this forced developing states into more debt, it was consistent with America's Cold War strategy, namely to preserve the geoeconomic relations of power founded at Bretton Woods. Global lending became conditional on structural adjustment: the World Bank had caught up with the 'critique of state interventionism and renewal of neoclassicism that had occurred in "professional economics" in the 1970s" (Peet 2009: 142). Demands for structural adjustment indicated a "process of change in the international financial system [...] using capital accumulating in surplus countries, as in the oil-exporting members of OPEC [Organization of the Petroleum Exporting Countries], to sectorally transform borrowing countries toward export orientation' (ibid.).

Hudson's critique of superimperialism is insightful yet lacks the explanatory force of critical IPE which redefines neocolonial relations of power in the capitalist periphery through dependency theory, following the critique of comparative advantage theory advanced by Prebisch (1950). Dependency is grounded in the weak political sovereignty given to the Third World after 1945 onwards, which Anghie describes as fractured and vulnerable, reflecting the Eurocentric logic of international law whose origins lie in the distinction between the 'universal' liberal civilizing force of European culture and the 'contingent' reality of non-European cultures. This distinction states that Europeans are sovereign while non-Europeans are not, suggesting that the history of the non-European world can only be explained in one way: it is a history of the incorporation of the peoples of Africa, Asia, the Americas and the Pacific into an international law which is explicitly European, and yet, universal' (Anghie 2004: 6).

From a world systems viewpoint, Frank examined the economic causes of dependency, observing that growth in the North can and does lead to growth 
in the South, but more often creates distortion. This paradox was not anticipated by neoclassical economics, he argues, which assumes that growth is universally beneficial (even if the benefits are not apportioned equally). Capitalism, argues Frank (1975, 1978), creates a global division of labour that sustains underdevelopment, where dependent states export minerals, commodities and labour, while importing capital, obsolete technologies and finished goods. This forcibly orients dependent states to the operational interests of transnational financial institutions in OECD economies: resources flow to dependent states but their allocation is determined by the interests of corporate elites rather than the development needs of dependent states. This sustains conditions of poverty and underdevelopment in the global South, yet this global division of labour is a core indispensable condition for the asymmetric consumption of resources in a globally integrated economy.

Laclau (1971) is critical of the abstraction of Frank's theoretical premises, and his failure to differentiate between 'capitalist mode of production' and 'participation in a world capitalist system'. The development of underdevelopment, he argues, derives from an historic logic of superexploitation in colonial economies which was designed to compensate for the low organic composition of capital - expressed as the low technical level of the productive forces. In the colonial epoch this encouraged corporations under imperial protection to fix social relations of production in an 'archaic mould of extraeconomic coercion, which retarded any process of social differentiation and diminished the size of their internal markets' (Frank 1971: 37), which has continued in the postcolonial period (cf. Carchedi 2001: 217). As Westra observes, in the 'twilight zone' of the global South, capitalist development has not just been uneven but stunted:

the modalities of capital accumulation never became central to the material economic reproducibility of most Third World societies. The stunted modalities of capital, and persisting pre-capitalist forms (whether they were original or spawned under historical conditions of contact between then capitalist and non-capitalist economies), then tended to work against each other in fashions extremely toxic for the material-economic reproducibility of human life in the Third World.

(Westra 2010: 182)

Although many developing economies rejected neocolonialism in the 1960s and 1970s and joined the Non-Aligned Movement to escape the ideological embrace of Western liberalism, the destabilization and/or violent overthrow of national-popular governments in the periphery led through an expansion of the debt relation to their reincorporation into the political economy of finance and the abandonment left-populist/corporatist alternatives to capitalism. The nihilism and violence of corporate globalization are revealed in the complicity of democracies in the state terrorism of client regimes in the global South in an effort to incorporate weak sovereign states into the political economy of 
global corporate power. This entails not only financial support for dictators but covert participation in the assassination and intimidation of intellectuals and labour activists, as well as training paramilitaries for counterinsurgency.

The economic and military power of the West was restabilized in the 1980s and given new relevance in a liberal-internationalist discourse that conceals the continuity and magnitude of clandestine Western interventions in support of corporate power in the capitalist periphery. Emphasizing the depoliticization of Western imperial power in the twentieth century, Schmitt looked beyond the myth of Anglo-American exceptionalism to suggest that the unique feature of Anglo-American hegemony lay in the apolitical orientation of capitalist expansion and violence, as a result of which the

economic stands in the foreground to such a degree that it is sometimes even used to deny the fact of imperialism at all, in that economy and politics are opposed to one another on the basis of an inherited nineteenth century antithesis, and the economic is situated as essentially something non-political, the political as something essentially non-economic [...] What the Anglo-Saxons do, in contrast to what the Prussians and other militarists have done, is by definition never imperialism but essentially something different, because it signifies only economic and therefore peaceful expansion.

(Schmitt 1933: 29)

The importance of this observation lies in Schmitt's reconnection of the economic and political. As we have argued, it is the false separation of economy and polity which prevents an understanding of capital as power - where the augmentation of power is not simply a means to but the real end of accumulation. Ownership of property is the source of corporate power, which withholds resources from general use, much as the Enclosure Acts in nineteenthcentury England allowed speculators to exclude land from social use. Abandoning the 'civilizational' legitimation of European imperialism in the nineteenth century, however, the juridical distinction of global imperial finance is not one between Christians and non-Christians, or 'civilized' Europeans and 'barbarians', but a financial distinction between creditors and debtors - that is, between sovereign entities that preside over the financial capacity to determine asymmetric relations of power (and thus to advance/ constrain the development of subject peoples), and weak sovereign entities whose contingent territoriality and autonomy are defined by their relation of dependence to transnational corporate actors.

Whether this new 'division of peoples and states is more peaceful than those of previous centuries', argues Schmitt (2011a: 31), is a 'question unto itself'. What matters is that the articulation of hegemony in the neutral language of 'economic modernization', 'free exchange' and 'pacification' indicates the juridification of international politics in the interwar period, a defining moment in the transition from realism to 'false normativism', 
which Schmitt traces back to the Kellogg-Briand Pact of 1928. This agreement licensed, in an 'elastic' form, the right of a world power to pacify the earth by appealing to internationalism: 'Such an elasticity, such an ability to operate with broad terms and to force the peoples of the earth to respect them, is a phenomenon of world-historical significance' (ibid.). The result is not merely decisional sovereignty but the capacity to create order by determining meaning through the definition and application of political concepts: "with those decisive political concepts the issue is who interprets, defines and applies them; who says, by means of concrete decision, what is peace, what disarmament, what intervention, what public order and security' (ibid.).

To the extent that one state pursues the 'aggressive democratization' of other states, the outcome is imperial relations of power (Musgrave \& Nexon 2013: 133). However, while capitalist relations of power are hierarchic and asymmetric, their operation is concealed through the mediation of international institutions that claim to represent the 'international community' (ibid.: 143). Despite attempts to construct a new justification for empire grounded on humanitarian intervention and democracy promotion (Dahbour 2003; Bricmont 2006), the geopolitical agency of the Clinton, Bush (Jr) and Obama Administrations is founded less on imperial virtue than the securitization of capitalist finance as a transnational mode of power, as a result of which the economic utility of military intervention has altered.

The material determination of capitalist geopolitics and the implicit correlation between financial and military power are revealed in the exceptional force of 'shock and awe' as a strategy to create and annihilate opposition to globalizing capital. The decision by the US to employ exceptional force in Afghanistan in 2002 and Iraq in 2003 not only finds its origins in fascist military strategy (Bromwich 2003), but has a dramatic parallel in the exceptional intervention by the Federal Reserve in the financial markets after September 2008 to prevent an unwinding of debt from destroying the Western banking system (Rickards 2011). Just as military force serves financial ends, the exceptional power of the dollar enables the US to sustain global liquidity as a condition for the global fiat money economy: liquidity constitutes a relation of trust $-\mathrm{a}$ 'peculiar type of trust that must reign in the financial markets [...] the trust that lenders - meaning people who buy shares, the case of financial markets - must feel in their ability to sell what they buy, at any time and with no certainty' (Amato \& Fantacci 2012: 17). Confidence persists only as long as liquidity persists and vice versa, though (as Keynes recognized) the expansion of liquidity is hardly ideal for society: 'because liquidity does not exist from the outset - or cannot constitute the basis for the functioning of a system of healthy credit distribution - it can only exist as long as no questions are asked about it, or at least as long as we pretend to know what it is' (Amato \& Fantacci 2012: 19). Liquidity is thus a fetish, and as 'long as people believe in the fetish, it will dispense its supposedly beneficial effects. When they stop, the fetish is finally revealed for what it has been all 
along: something incapable of adequately supporting the basic relations involved in finance' (ibid.). It is unsurprising, therefore, that liquidity (rather than demand) has been the driving force of business cycles in recent decades, fuelling investment bubbles, including the bond market bubble which allows the US to finance liabilities of $\$ 17$ trillion. ${ }^{3}$ This liquidity fetish evolves in three phases: deregulation, financial innovation and irresponsible monetary policy. 'Financial deregulation and liberalization laid the foundations for financial engineering, while central banks have pumped more liquidity into the financial system every time a bubble has burst, thereby perpetuating the bubble era' (Arestis \& Karakitsos 2013: 68-9).

America's decision to declare a global state of exception and intervene in energy-rich regions indicates the material determination of geopolitics in the present era. As Fouskas and Gökay $(2005,2012)$ argue, NATO's energy wars in the 'Eurasian Balkans' are being waged not simply to secure oil pipelines or to limit the evolution of a Eurasian economic and security system independent of the US, but to prevent energy-rich states from conducting nondollar-denominated oil transactions, which would undermine the power of the petrodollar cartel - the real motive for the occupation of Iraq in 2003 and invasion of Libya in 2011. Yet the state of exception announced after 9/11 also indicates that while interventions may increase profits for US defence firms, oil companies and private contractors, their direct contribution to aggregate capital accumulation is limited (Nitzan \& Bichler 2006: 6). The real impact of 'cheap wars' is felt indirectly through the exploitation of political instability in energy-rich regions, which exerts a mild inflationary effect on the price of assets and consumer goods in advanced economies, which in turn offsets deflationary pressures by incentivizing spending, stabilizing the market power of dominant capital and reducing the burden of debt repayment.

Although deflation at first sight seems to benefit households by increasing purchasing power, it is fatal for capitalist economies dependent on debt to finance spending and investment. Devalued currencies increase the cost for business and government of meeting debt-repayments, and while central banks can respond to inflation by raising interest rates until borrowing drops, stimulating borrowing/spending is impossible beyond a certain point because it is self-defeating to reduce interest rates below zero - although this policy has been tried by the European Central Bank (ECB) to encourage lending by charging eurozone banks for the excess deposits they place with it (The Economist 2014). The actual cause of deflation is the disconnect between wages and productivity (no more so apparent than in Germany), for if workers' pay does not increase commensurate with rising labour productivity then real wages fall and so do prices because fewer people can afford discretionary spending. To avoid wage increases in line with rising living costs, however, it is easier for corporate firms to maintain liquidity through monetary expansion and mild inflation by allowing the price of key commodities such as oil to rise - as occurred dramatically between 2003 and 2008 to the advantage of large energy exporters like Russia. ${ }^{4}$ 
The Federal Reserve's long-term policy of credit easing has been accompanied by an expansionary fiscal policy to mitigate the threat of deflationary recession following the collapse of the long boom of the 1990s (Kawamura 2013), leading to an increase in government spending on 'homeland security' and foreign wars which is estimated to have cost US taxpayers $\$ 3$ trillion (Stiglitz \& Bilmes 2008). The inflationary effect of 'cheap wars' supported by the 'weapondollar-petrodollar coalition' indicates the private power of corporations whose transnational interests transgress the national economic interests of citizens in the US. Mapping the profits of the "weapondollarpetrodollar coalition' against inflation and energy wars, Nitzan and Bichler draw three conclusions, namely: (i) energy conflicts are preceded by a danger zone when rates of accumulation enjoyed by oil companies decline; (ii) each energy conflict is followed by a period in which corporations in the energy sector achieve above-average rates of accumulation; and (iii) with one exception, oil companies consistently fail to 'beat the average without an energy conflict first taking place' (Nitzan and Bichler 2006: 8). This highlights the proximity between corporate and political elites who exchange positions through the 'revolving door' of corporate directorships and political offices in New York, Washington and London. Yet the power advantage gained by dominant capital translates into a net loss for society due to the distributional impact of inflation which sustains the illusion of nominal GDP growth in the short-to-medium term (roughly a decade), but eventually erodes capital through the debasement of the currency:

During the welfare-warfare state, inflation usually involved a wage-price spiral that worked to limit the differential increases in profits [...] The situation now is very different. Workers in the United States are locked in global competition with workers in China, India and other 'emerging markets', which means that wages do not rise - and sometimes even fall in the midst of price inflation. In this context, a four percent inflation translates to a four percent increase in the mark-up and to a far larger increase in profits.

(Nitzan \& Bichler 2006: 14-15)

To this end America's bipartisan political elites first had to abandon their duty to defend the national interest - to honour their mandate to work for the interests of US taxpayers who watch impotently as republican democracy is overtaken by a corporate oligarchy presiding over an entrenched system that thrives on malinvestment (systematic misallocation of resources through corporate-state corruption). Indeed, as Martenson (2011) observes, the political betrayal of the US electorate mirrors in surprising ways developments in Argentina prior to the collapse of 2001, a country in which neoliberal shock therapy and fixed exchange-rate currency regimes led to a fire sale of national assets, inflation, capital flight and eventually sovereign default. 
America's reversal of fortune from the world's most powerful creditor to the world's major debtor highlights the contradictory impact of globalization. While US financial strategy after 1945 sought to maximize American autonomy relative to the rest of the world, the opposite is now the case as constraints on America's freedom of manoeuvre (as consumer of last resort, supplier of global liquidity and indebted state) intensify and as the utility of US military preponderance for client states declines. Although the US retains a 'very high degree of financial and military power', suggests Konings (2008: 56), 'it has no inherently privileged relationship to processes of decentralized globalization'. Eventually, he argues, the US will have no choice but to 'bow before the power of globalizing financial markets and a more decentralized pattern of [global] financial authority' (ibid.: 56-57).

Yet rebalancing has implications for the status of the US as a First World state because consumer purchasing power, "which represents the entirety of means of payment (wages and revenue) used in the buying of goods already produced, already present, is strictly subordinate, as a lesser power flow, to the flows of financing' (Lazzarato 2012: 83). Finance is the 'power for prescribing, ordering, that is, a set of possibilities for choices and decisions with regard to the future, which anticipate what the production, power relations and forms of subjection will be' (ibid.: 84). As we shall see in Chapter 7, while the impact of reserve currency diversification is hard to predict, even if China proceeds cautiously in its Grand Strategy, the evidence suggests that in order to delay the arrival of a multi-currency reserve system the US will intimidate both contenders and allies seeking alternatives to the petrodollar system, leading to currency instability and wider geopolitical conflict.

\section{Accumulation crisis}

Marxian theory suggests that each 'long-run or structural crisis (and related sequence of periodic expansion and contraction and sectoral change) is conjunctural in nature [...] The conclusions of historical crises constitute the beginnings not only of subsequent expansions, but also of succeeding crises' (O'Connor 1984: 55). Furthermore, the way in which each preceding crisis is resolved determines the form of succeeding crises - whether this entails capital restructuring, labour intensification, mass unemployment, expansion in the financial circuit of the state as a component in the total reproduction of capital, or war. Expansionary phases in capitalism lead to crises of overaccumulation (overproduction/inflation/declining demand), threatening the profitability and viability of capitalist commodity production which exists purely for its own sake rather than to meet expanding social needs. In addition, the period of recovery after each successive crisis is always temporary while each expansionary phase fizzles out more rapidly than the previous upswing without resolving the conditions that produced it.

As Brenner (2009) observes, growth in the US from the end of the 'dotcom boom' to the subprime crisis was the slowest in post-war history, yielding 
a zero increase in median family income for the first time since 1945. While it is assumed that capitalism consistently 'defeats diminishing returns to fixed resources through technical change' (Foley 1986: 45), countering the tendency towards a lower composition of capital and longer turnover times which negate rising surplus-value, accumulation crises actually lead to 'rising money prices of commodities, shortages of certain commodities and certain types of labour-power, and higher interest rates. The economy then reaches a point where aggregate demand and output turn down sharply, and the demand for labor-power falls' (ibid.: 47). As capital withdraws from productive investment, as medium-sized firms go out of business, and as employment law is revised in favour of capital, accumulation 'resumes its upward course' (ibid.: 48).

In volume I of Capital Marx stated that capitalist accumulation depends on a continual realization of additional surplus-value as a directionless process that proceeds ad infinitum: 'accumulation for the sake of accumulation, production for the sake of production: this was the formula in which classical economics expressed the historical mission of the bourgeoisie [...] Classical economics takes the historical function of the capitalist in grim earnest' (Marx 1976: 742). For Marx there is a direct link between the ways in which labour, capital and technology are combined in the production process and the realization of value in excess of the costs entailed in capital investment and the material reproduction of labour-power. Where ceteris paribus the production of surplus-value increases more rapidly than the value of additional capital, accumulation can be sustained, but at a certain stage in the cycle - where the level of organic composition of capital invested in capital goods (industrial-technical capacity) overtakes consumer goods capitalization, or where the purchasing power of new consumers is exhausted without introducing unsustainable levels of debt, then demand collapses and production halts (O'Connor 1984: 65-66). For Marx, the problem of overaccumulation reflects the contradiction inherent in capitalist commodity production:

The contradiction [...] consists in that the capitalist mode of production involves a tendency towards absolute development of the productive forces, regardless of the value and surplus-value it contains, and regardless of the social conditions under which capitalist production takes place; while, on the other hand, its aim is to preserve the value of the existing capital and promote its self-expansion to the highest limit (i.e. to promote an ever more rapid growth of this value). The specific feature about it is that it uses the existing value of capital as a means of increasing this value to the utmost. The methods by which it accomplishes this include the fall of the rate of profit, depreciation of existing capital, and development of the productive forces of labour at the expense of already created productive forces.

(Marx 1959: 249) 
Capital is thus incompatible with real social abundance: production must either decline or be terminated before social needs are satisfied because capital is a mode of power that requires scarcity to sustain profitability - that is, where supply is restricted by declining exchange value not use value. This is the case because the competitive valorization of capital drives demands for innovation and productivity; yet the increasing abundance of the means of labour and the expansion of social needs threaten the conditions under which surplus-value can be realized profitably, leading to extended periods in which production must decline or cease completely.

The tendency of capital towards overaccumulation also highlights the centrality of the state circuit of capital in facilitating consumption. The state form of capital is determined not simply by provision of social goods that cannot be produced for private gain, or to promote Pareto optimality, but to 'satisfy the conditions for the self-expansion of capital' (Eaves 2011: 4). Capital, argues Eaves, is 'production run amok' - production for its own sake; the state, on the other hand, is 'consumption for the sake of capital' - a mechanism for consuming the excessive productive capacity of society expressed as an overaccumulation of surplus-value. The expenditure of the state is derived from 'that portion of the surplus produced by capitals which does not go into either the expansion of variable capital (wages) or the expansion of constant capital (machinery, raw materials, etc.)'. The state 'pays for these expenditures by issuing newly created ex nihilo pecuniam' (ibid.), which only acquires value because it is based on a social contract predicated on the sovereignty of the issuing state.

Yet it is capital itself that brings its state form into existence, and there is no alternative to money creation in the advanced economies because capital requires the state to overcome the antagonism between production for private profit and underconsumption by absorbing into itself the growing mass of surplus-value that cannot be realized/invested profitably. In addition, because the natural state of capitalism is stagnation (rather than growth), accumulation regimes tend towards financialization, labour intensification and the erosion of legal protections for labour and the environment - threatening the essential non-capitalist (societal and ecological) preconditions for the future reproduction of the system (Kotz 2007). The contradictory logic of accumulation can be seen as a response to the effect of 'bad infinity' in the ontology of capital which creates demand but cannot meet social needs, and therefore thrives on lack. Drawing once again on Hegel, Marx argued that capital is oriented towards never completed infinitude: 'Fixed as wealth, as the general form of wealth, as value which counts as value, [capital] is therefore the constant drive to go beyond its quantitative limit: an endless process' (Marx 1973: 270). To sustain the self-valorization of value entailed in the quantitative augmentation of capital, all finite forms of realized capital (money, savings, etc.) constitute a barrier to capital's drive towards infinity and must be returned to the circuit of capital through periodic recessions which create scarcity and regenerate demand. Overaccumulation can also be understood in 
poststructuralist terms as a political response to the logic of capitalist excess, for it is the state alone that is 'capable of realizing capitalism's supreme goal, which is to produce lack in large aggregates, to produce lack where there is always too much, by effecting the absorption of overabundant resources' (Deleuze \& Guattari 1977: 235).

The 1930s slump ended in fascism as an historical form of postliberal capitalism. As Eaves argues, economic fascism is 'subject to certain conditions, the most important of which is that the consumption of the mass of society must never expand beyond that point where the sale of labor power is threatened, i.e. must never exceed the average of the daily wage' (Eaves 2011: 2). Although consumption must increase, he argues, it must also 'impoverish society on an ever increasing scale [and] the productive capacity of society must be routinely and systematically destroyed' (ibid.). Yet the destruction of the Second World War testifies to the utility of military conflict for the survival of capitalism, not simply as a means for acquiring territory/resources, but through the institutionalization of war preparedness. This assumed a variety of forms in Europe, Australia and North America and has been extensively studied by regulation theorists who examine the changing patterns of state intervention and political legitimation in Fordist accumulation regimes after 1945 (Aglietta 1979; cf. Jessop 2001).

This model provided unprecedented economic and political stability in Europe and the US for almost three decades, but led to stagnation in 'phase B' of the Kondratieff cycle due to a crisis of overproduction following German and Japanese recovery in the 1960s, which destabilized the Bretton Woods system, forcing the US to abandon gold convertibility and devalue the dollar in an attempt to remain economically competitive. When this failed, the US re-established the value and international prestige of the dollar by signing deals with Saudi Arabia and OPEC states between 1973 and 1975 to denominate oil sales exclusively in dollars in return for US security guarantees, creating an artificial global demand for dollars which was then recycled as investment in US Treasury liabilities and US banks. This dollars-for-oil system was favourable to the US as it required less monetary discipline than a gold standard, allowing the Federal Reserve to expand the US monetary base exponentially. Foreign governments had no option but to lend their currency reserves to finance US consumption, which placed the burden of the balance of payments deficit on foreign states rather than US taxpayers or US corporations. Far from signalling the end of US domination of the capitalist chain, argues Hudson, dollar devaluation became the object of US financial strategy (Hudson 2003: 22). This inaugurated a period of benign neglect characterized by loose monetary policy and higher inflation which endangered the dollar's 'very position as key currency and the international financial structure based upon it' (Hudson 2003: 34-35), before the Volcker shock when the Federal Reserve tightened credit and laid waste to America's industrial base through high interest rates, unemployment and recession (ibid.: 49). 
Attempts to understand capitalist crisis by analysing regulation are useful, but a focus on modes of intervention restricts the object of the analysis to 'superficial and transitory features of capitalism, which are one-sidedly elevated to defining features of a distinctive stage of capitalist development' (Clarke 2001: 77). As a result, recession is misdiagnosed 'as a crisis of particular "modes of regulation" of capital accumulation, which can be resolved by developing new forms of regulation, rather than being seen as a crisis which expresses the contradictory form of accumulation itself' (ibid.). As O'Connor argues, a contradiction exists between the ends of regulation:

On the one hand, the working class/salariat forced the state to protect and enhance the value of its labor-power and labor services, increase stability in labor markets, compensate for losses to the value of laborpower, and so on. In this way the state followed policies which intensified the tendency for the rate of exploitation and profit to decline. On the other hand the state also needed to compensate for previous policies which adversely affected exploitation and profits.

(O’Connor 1984: 225)

In this sense, the state is 'constantly trying to undo with one hand what it [has] done with the other' (ibid.). As we have seen, neoliberals sought to address the accumulation crisis of Fordism by reducing state regulation, cutting public services and tightening fiscal and monetary policy while shifting the burden of debt onto private consumers in an attempt to stimulate demand. In addition, incentives were introduced to intensify competition between workers in the reserve army of labour who had to accept reduced compensation and deteriorating labour conditions. Here it is useful to distinguish between the intrinsic capacity (power resources) of labour and capital on the one hand, and the hegemonic capacity (ability to use those power resources) on the other. The intrinsic capacity of labour rests on its ability collectively to resist changes in working practices; the intrinsic power of capital, on the other hand, rests on its mobility - its capacity to withdraw from investment and seek new sources of profit, and to determine the juridical framework of the capitalist state form.

For Lembcke, hegemonic capacity is the 'ability of one class to intervene in the process by which the opposite class generates its own intrinsic capacity' (Lembcke 2002: 16). The power of capital and profitability of its investments thus depend on its ability to 'maintain the accumulation process (and thus continue to generate its intrinsic capacity) while blocking the contradictory effects of accumulation by mitigating the collectivization of the working class - that is, to exercise hegemonic capacity' (ibid.: 17-8). The effect of the Volcker coup was to attract funds to the US while undermining US manufacturing, which relocated production offshore. A further effect - following Reagan's 'militarized counterrevolution' - was to boost defence spending by allowing the state to consume overcapacity as a 'surrogate' export market. 
Trade and balance of payments deficits enabled the US government to legitimize reduced spending, but this policy had global implications, for given the weight of the US in the world economy, few states 'could afford not to follow US monetary policy and suffer with the US the subsequent recessionary consequences of mounting unemployment and slowed growth' (Westra 2010: 116). Volcker's monetary policy also sealed the fate of the developing world, leading to a reconfiguration of the global financial system to exploit new opportunities for lending as debtor states adopted SAPs in return for emergency IMF loans.

Yet the contradictions of overaccumulation cannot be resolved indefinitely by blocking collective action or internationalizing the means of production through a global division of labour. This is a consequence of the logical contradiction between two forms of wealth: material wealth and abstract wealth (expressed in the reified form of money capital). In capitalism, material wealth is only ever produced if it can also be represented as value - that is, if it results simultaneously in the valorization of value, and where this 'cannot be achieved because the valorization of capital has ground to a halt, material wealth also stops being produced. Goods are even destroyed because they cannot be sold despite the fact that needs are left unmet on a massive scale' (Lohoff \& Trenkle 2012a: 1). Since the 1970s, the world has experienced an overaccumulation crisis because productivity is too high to sustain the process of capital valorization:

Capital has to reproduce itself because otherwise it ceases to be capital and for that purpose a continually growing workforce has to be utilized to produce commodities. But at the same time, competition is driving an unstoppable productivity race that [...] leads to the permanent replacement of labor with physical capital. That is the fundamental internal contradiction in the capitalist mode of production that ultimately has to turn on the mode of production itself. Specifically, if productivity is so high that huge masses of labor-power are made superfluous, that jeopardizes the very basis of capital valorization. This is precisely what is at the core of the fundamental structural crisis that the global capitalist system has found itself in since the end of the post-war boom.

(Lohoff \& Trenkle 2012a: 2)

As long as capital can overcome barriers to accumulation through internationalization this contradiction can be suspended and the spatial limits of capital extended. However, this suspension is always temporary due to uneven development in the global economy. The crisis of Western capitalism exists not because of globalization but as a consequence of the intensifying competition that drives capital to escape restrictions imposed by variable capital (labour-power) through the perpetual innovation of new financial instruments and deregulated foreign direct investment in emerging markets. Yet the relentless drive for accumulation suggests that the attempt of capital to overcome barriers to accumulation by penetrating world markets has reached 
its limits as overaccumulation appears on a global scale' (Clarke 2001: 8081). In this sense, the transition 'from one phase of the cycle to the other is not in the fact of the global character of capital accumulation but its form' (ibid.). The recession of the 1980 s led to a massive devaluation of capital, to the destruction of surplus productive capacity and to a disciplining of labour, followed by a consumer boom that proved insufficient to restore stable and profitable accumulation in the long term. Western corporations were subsequently able to prosper in the boom of the 1990s not through sustained innovation or investment but through new opportunities afforded by postcommunist transition, the global expansion of the debt relation, by the capitalist transformation of China and its integration into the network of transnational corporate power through the WTO (Cox \& Lee 2012; cf. Westra 2012), and by the temporary collapse of Russia as a hegemonic power in Eurasia which offered Western financial and military elites new opportunities for intervention in regions previously closed to Western capital.

Although globalization has lifted large numbers of Asian workers out of subsistence, it has also triggered a chronic condition of overcapacity in the world economy which can ultimately only be resolved through controlled or uncontrolled deleveraging. Despite the flood of cheap money created by expansionary monetary policies in the US, EU and Japan - which have stoked 'destructive booms' in emerging markets that cannot easily be controlled - debt overhang, overproduction and glut in the global economy are exerting downward pressure on prices, confounding Western financial elites whose goal is to prevent long-term stagnation and deflationary recession (Warner 2014c). In the absence of sustained growth and cautious investment, predatory corporations in western economies have embraced financialization, leading economists to measure business 'success' by the expansion of corporate balance sheets (irrespective of the quality of assets acquired), by capacity to leverage credit and by capacity to maximize earnings per share in order to increase 'shareholder value'. Financialized corporations adopted ingenious strategies to simulate growth to the extent that '[t]rillions of dollars that could have been spent on innovation and job creation in the US economy over the past three decades have instead been used to buy back stock, the sole purpose of which is to manipulate the company's stock price' (Lazonick 2013: 235; cf. Cox 2012). As Froud et al. (2006) argue, the ideology of shareholder value has risen to become the standard against which all corporate business activity is judged, yet the concept is no more than an 'artifice' that presumes to know what market investors want (typically a 10-12 per cent return on investment after tax) (ibid.: 42). Yet, the authors argue, if we ignore the hype and examine the 'specifics about what management can do to improve financial results, then we find a good deal of tautology combined with a fairly traditional 1980s concept of strategy' (ibid.: 47). The reality is that financial ideologies like shareholder value yield disappointing results, while benefiting CEOs whose remuneration has grown exponentially. A further outcome is rising corporate malfeasance and personal enrichment - value skimming that 
privileges wealth without function because it is not founded on actual increases in performance and requires only an 'elite structural position where one or a few senior figures can take advantage of ownership rights, deals or operations close to a large income stream' (ibid.: 60).

This trend has resulted not merely in the overvaluation of non-competitive firms and their artificial expansion through mergers and acquisitions, but in the haemorrhaging of salaried jobs among intermediate strata who formerly comprised the basis for a prosperous consumer economy in the post-war era (Lazonick 2013: 264; Roberts 2013). As Lipietz (2001) observes, it is the aggregate of median incomes of lower-middle- and working-class wage earners that allows consumer economies to prosper, and the flexibilization of wage relations in the US has reduced the life chances of educated strata, creating a new precariousness characterized by the declining purchasing power of lowpaid workers and an expanding class of socially excluded individuals who have abandoned the search for employment. ${ }^{5}$ At the other extreme, CEOs have become an 'ineffectual officer class, whose role is to manage events and avoid disaster but not to produce high performance or glorious victory' (Froud et al. 2006: 91).

It is the form in which capital escapes the contradictions of a preceding phase of expansion that is crucial to understanding the next phase of structural crisis, and this is particularly evident in the case of the liberalization of capital flows that followed the recession of the 1970s. Capitalism traditionally maintains itself, argues Wallerstein, 'by mechanisms that restore equilibrium every time its processes move away from it. The equilibrium is never restored immediately, but only after a sufficient deviation from the norm occurs, and of course, it is never restored perfectly' (Wallerstein 2006a: 75).

Neoliberal capitalism increasingly resembles a form of economic fascism shorn of its offensive ideological characteristics, which thrives on the postponement of debt repayment through credit expansion, loose monetary policy, the resort to 'cheap wars' to counter deflationary pressures and extend new opportunities for accumulation, and investment in the apparatus of domestic state repression and surveillance to manage potential resistance to the corporate appropriation of national incomes. At present each of these conditions is being met, with potentially catastrophic consequences for social cohesion and political stability in the US, UK and other low-growth western economies. As Wallerstein cautions, the mechanisms that restore equilibrium cannot persist indefinitely because secular trends start to exhibit 'asymptotic' properties - that is, they incrementally approach the point where continued expansion is no longer viable without a risk of systemic collapse.

For both Wallerstein and Brenner, the recurrent financial crises in the world economy which began with a tightening of US monetary policy in the 1980s and triggered the end of Japanese growth, the Mexican crisis of 1994, the Asian financial crisis of 1997, the Russian default of 1998, the collapse of the US stock market in 2000-01 and the global financial crisis of 2008, indicate the risks attendant in liberalizing transnational capital flows on the one hand, and the 
need to rebalance living standards and Western consumerist excess on the other. The bottom line, argues Brenner, is that to 'resolve the problem of profitability that has so long plagued the system [...] the system requires the crisis that has so long been postponed' (Brenner 2009: 9, emphasis added). The source of the problem lies in the declining rate of profit on capital invested for which the only logical (but politically unacceptable) solution is to allow the unconditional bankruptcy of unprofitable sectors of the economy, for it is only 'by way of crisis that, historically, capitalism has restored the rate of profit and established the necessary conditions for more dynamic capital accumulation' (ibid.).

Despite accusations of 'crony capitalism' by Western commentators, Asian economies living beyond their means in the 1990s recovered from the crisis of 1997 by accepting structural reform, although as we shall see in Chapter 6, Asian economies have instituted regional financial structures to prevent a recurrence of the crisis. Yet Western elites refuse to follow the Asian example and negotiate necessary structural changes which would lead to a loss of international financial prestige. Instead, the systemic crisis of the West is concealed by the ever-larger level of abstract wealth generated through the leveraging and securitization of debt and the creation of new investment bubbles through credit expansion in the equity, property and bond markets.

The crisis of Western economies stems not simply from the venality of Western bankers, therefore, but from attempts by corporate investors and financial mangers to delay the structural crisis of valorization facing the financial system - the approaching 'great devaluation' that governments have managed to evade by pumping liquidity into the system and transferring private losses to taxpayers to prevent deflationary recession, and by forcing interest rates below market-based levels (Pento 2013b). The aim is to forestall a collapse in currency values and assets created through the leveraging of paper claims to future value, which are sustainable only as long as sources of confidence in the market are artificially fabricated and maintained (Lohoff \& Trenkle 2013: 230). Yet by drawing the state ever further into a defence of capitalist sovereignty, this is leading to the further statization of capital allocation in 'liberal' economies illustrated by the increase in the ratio of public expenditure to GDP in the UK from 40.6 to 51.0 per cent in the period 1997-2010 (Winiecki 2013), and the tripling of Britain's national debt from 35 to 100 percent of GDP between 2003 and 2015. This indicates a dramatic shift away from 'equilibrium' as corporate-state elites struggle to sustain the accumulation regime of financial capital and prevent a deflationary spiral through manipulation of currency markets to slow the transition to a posthegemonic global growth system in which capital flows are decoupled from dollar hegemony.

\section{From financial instability to monetary collapse}

Perspectives on the causes of financial crises differ significantly between neoclassical theory, Austrian School economics, Keynesianism and Marxism. In the former case, the occurrence of financial crisis is seen largely as a 
consequence of 'irrational exuberance', inadequate legal regulation, excessive government intervention in the market, and the expansion of the state itself as an institution that is 'too big to fail' (Patton 2013). The target of Austrian School theory, on the other hand, is the bloated welfare state model of Western capitalism and the dissonance between future liabilities and future income that is pushing Western economies towards fiscal collapse. A further target of the Austrian School is the moral hazard implicit in the use of taxation to socialize risk and 'reward' corporate failure, and the tendency of states to flood their economies with liquidity or promote speculative investment bubbles ('Ponzi schemes') which offer easy prosperity but end in disaster as credit expansion ends and interest rates climb (Garrison 2000).

Keynesians such as Minsky (2008), meanwhile, stress the danger of investment bubbles and financial instability, but go further than liberal political economists to argue that the 'financial structure of the advanced capitalist economy exhibits an internal flaw driving it relentlessly from robustness to fragility, making the whole economy susceptible in the end to debt-deflations of the kind exhibited by the Great Depression' (Foster \& Magdoff 2009: 17). For writers like Minsky (2008), instability is endogenously determined, and there is a tension between the lender of last resort function of the state and the fragility of the financial system when the latter reaches such levels of volatility that the former can no longer function effectively. When the Federal Reserve intervenes to protect a financial instrument, therefore, it does so to forestall an incipient crisis; yet it does so by creating the conditions

for a resumption in the process of increasing indebtedness - and makes possible the introduction of new instruments. In effect, the Federal Reserve prepares the way for a type of financing that is a necessary but not a sufficient condition for an investment boom that is brought to a halt by financial crises [...] deficits of Big Government are the sufficient condition. By sustaining aggregate demand, they sustain corporate profits and feed secure assets into portfolios. These conditions mean that an investment boom will occur quite soon after a recession and the investment boom generates the demand for financial instruments that leads to another bout of inflation and crisis.

(Minsky 2008: 95)

Finally, for Marxists there is an inherent link between overdevelopment of the financial sector of the economy and stagnation, which neither orthodox nor heterodox economists seem willing to discuss. As we have seen in the present study, Marxists recognize that debt is a structural feature of all capitalist economies, not just peripheral states in the global South that George (1988) characterized as 'condemned to debt'. As Foster and Magdoff (2009: 20) argue, the growth of debt and speculation are the 'main means by which the system [has] managed to avoid sinking into a slump, while not allowing it to overcome the underlying stagnation tendency'. 
We have seen that Western economic power was acquired through the expansion of Euro-American capital in the nineteenth and twentieth centuries - a process led by the financial imperialism of the Anglosphere. Considered dialectically and historically, therefore, it is of little surprise that the present crisis threatens to exert its greatest impact on the historic centres of capital - the US/UK, in addition to the ageing economies of Japan, Switzerland, the eurozone and states in the eurozone periphery. A key feature of the present crisis is the instrumentalization of the state form of capital to sustain a return to 'business as usual' engineered through exceptional intervention in the financial system and the development of new forms of transnational governance linking corporate, financial and state actors to promote systemic stability and revalorize popular belief in finance as a means to expand opportunities for future accumulation. However, unique as the present crisis is - a distinguishing feature being the moral hazard created by the knowledge that state-sponsored agencies will purchase toxic debt to prevent a collapse of the banking system (Hendrickson 2013: 208) - the general pattern of credit expansion, overleveraging and devaluation is also cyclical and must be understood within the structural and historical context of fluctuating globalization since the late nineteenth century - the internationalization of capital flows that lies behind the international crises and military conflicts of the twentieth century. At the heart of this process is the accumulation of value for investors beyond the limits of secular cycles of expansion and contraction while perpetuating a sense of prosperity among Western consumers whose economic status is distorted by official statistics on national income (GDP per capita as a socially undifferentiated measure of wealth), which conceals the true extent of poverty and underemployment in Western economies. ${ }^{6}$

Pettifor (2006) highlights the parallel between globalization and the fluctuating power of international finance which culminated in what she terms the 'third crisis of globalization', namely the world slump of the 1930s. 'For the third time in 56 years', she argues, the 'system of economic government by international capital markets was discredited and brought to an abrupt end. The cost, in human, social, financial and political terms was immense, indeed incalculable' (Pettifor 2006: 36). Government by international finance was, as we have seen, temporarily brought to a close with Bretton Woods until the recession of the mid-1970s, when political pressure was again directed at Western governments to relinquish control over exchange rates and capital flows, with surplus economies being invited to invest their wealth to support a massive expansion of US debt, allowing the US the 'exorbitant privilege' to continue printing the world's reserve currency (Eichengreen 2011). This privilege has allowed the US to consume global wealth and sustain an economy in which 'low-income countries' earnings from exports [and] financial inflows, have been used to build up reserves of US Treasury bills, i.e. to make cheap loans to the US rather than to undertake domestic spending to reduce levels of poverty' (Pettifor 2006: 49). 
At the same time, pressure from global capital has led governments in the West to deregulate domestic consumer credit through removal of controls on inflationary lending and borrowing, increasing not only average levels of exposure to debt but the number and range of institutions and firms authorized to issue loans. Where 'credit is used to inflate the value of assets', argues Pettifor, then 'even the limits imposed on borrowing by the value of assets evaporate, like bubbles. This is because unregulated credit offered to borrowers on the basis of an asset rising in price will rise in line with the inflating asset' (Pettifor 2006: 78). The result is the expansionary debt bubble that pushed the US and UK to the brink of financial collapse in 2008-09 as it became clear consumers had overreached themselves, creating unsustainable levels of private debt in addition to the unpayable national debts of both states. ${ }^{7}$

The Anglo-Saxon economies are now dependent on exponential and unsustainable borrowing just to continue growing at meagre rates of 1.25 to 1.5 per cent annually; they are, in effect, 'one-legged' (ibid.: 90), presenting corporate-state elites with an acute policy dilemma: cut borrowing through higher interest rates and reduce consumption, or reduce interest rates to maintain the economy on life support at the risk of promoting still higher levels of debt and future default, leading to the withdrawal of credit and a rapid return to recession. Failure to foresee the First World debt crisis suggests a blind spot in the ideology of neoliberalism which problematizes the efficiency of the public sector yet fails to question the natural logic of the privatized consumer as the ontological condition of growth: 'that economies are seen to be composed of consumers is now so taken for granted', Payne argues, that governments 'do not even have to be aware of the historically contingent nature of this object they call "the consumer" [as] an object of rarefaction, and not at all "natural" (Payne 2012: 6). Following Foucault, he suggests that the naturalization of the consumer as an economic 'given' constitutes a failure of governmental rationality, for ' $[\mathrm{k}]$ nowing how to govern requires an explicit vision of the human agents for whom one is governing' (ibid.: 44). The fact that the 'financial crisis has far surpassed in severity any of the systemic issues raised by the boom and bust of the late 1980s gives proof to the fact that there was a unique intensity and complexity to this credit boom' (ibid.: 147). The financial system and its human agents were, he concludes, left 'vulnerable to sudden reverses brought about by an absence of new credit money to support the already existing positions and asset prices that the previously created credit-money open up in the first place' (ibid.).

The explosion of debt in Western consumer economies has been accompanied by an explosion in the trade for mortgage-backed securities and financial derivatives - a high-risk speculative activity that reflects the transition from the original commodity circuit of capital $\left(M-C-M^{\prime}\right)$ to financialized capital $\left(M-M^{\prime}\right)$, where production of value becomes dependent not on labourpower but on the capacity of the financial system to extract more surplus from the general population (Foster \& Magdoff 2009). A central feature of neoliberal financialization is the accumulation of fictitious capital: leveraging 
of paper claims to future in the form of volatile investment funds in search of high-yield outlets. The present economic and financial crisis of the West highlights the economic contradictions raised by this expansion of fictitious capital - a quantity of surplus-value that distorts wealth production and undermines financial stability, but which constitutes a form of 'accumulation symmetrical with new processes of value production' (Marazzi 2010: 48).

Capital, argues Goldner, 'without resort to a full-blown depression or a Third World War, has been struggling to establish a new standard of value to supersede the exhausted one associated with the post-war boom'. To achieve this, he adds, it must 're-equilibrate the existing total paper claims on wealth [...] with existing surplus-value in a new, acceptable rate of profit, at the same time that it expands the reproduction of global society. Yet, because of the preservation of fictitious capital against devaluation, at the expense of material production, it has failed to find this new equilibrium' (Goldner 2009: 4). Yet fictitious wealth created by securitization is still real, for the aim of capitalism as a mode of power is to create a basis for capitalization and expand the quantity of money available in the system by trading on future values - trades in which nominal values of financial derivatives lose all direct or indirect correlation with labour-power itself, acquiring relative autonomy from local economies of production and investment. Capitalist accumulation is a directionless process that recognizes no formal limits; it is logically incomplete until the leveraging of value collapses in a spiral of devaluation. Supported by states, corporate profits can be made almost indefinitely by innovating more complex financial instruments as claims on future value, but this constitutes an extreme form of commodity fetishism, where the source of value in the exploitation of labour is rendered covert: profit is effectively made by utilizing borrowed capital to engage in speculative trades which are not tied to commodity-based assets.

This process is 'astonishing' because the initial capital invested acquires a kind of dual existence: on the one hand, argue Lohoff and Trenkle, the initial capital is held by the 'borrower of the company issuing the shares'; on the other hand, 'the creditor of the shareholder holds a mirror to the initial capital, namely a property title (loan, share, etc.) that represents a momentary claim' (Lohoff and Trenkle 2012b: 2). Although fictitious capital appears to yield unreal values, this doubling is not imaginary, for it 'acquires an objective social existence in the form of securities as long as the certified claim appears to be redeemable'. This claim to value 'represents capitalist wealth in exactly the same way as the value that is squeezed out of living labour' (ibid.). In effect, fictitious capital displaces accumulation from the sphere of production to the sphere of speculation, but this does not mean the end of capitalism as a mode of production contingent on valorization. Rather, it simply points towards the potential devaluation of presently overvalued assets - unsecured financial derivatives that are only overleveraged paper claims to future value.

For Lohoff and Trenkle (2013), the crisis of the Western economies cannot be explained simply through demand-side explanations based on declining 
consumption. It must also take into consideration the replacement of human labour with technology (knowledge-based capital) in the 1980s and 1990s ('third industrial revolution') which pushed more workers out of productive wage labour than it added, while retaining labour as the primary source of capital valorization in commodity-determined societies. This has led to a tension between the capacity of the system to generate surplus-value through commodity production and the compensatory growth of speculative financial capital derived through the generation of fictitious value. To compensate for the declining rate of profit in advanced economies, finance has delayed recession and devaluation by seeking new sources of profit in the future value of financial instruments, a strategy that fails to solve the valorization problem of capital yet exponentially increases the fallout from a collapse in the 'real economy-source' of derivatives whose present/future values are being traded.

Trade in mortgage-backed securities represents the objectification of a credit relation and anticipated future yields based on it, and thus constitutes an autonomous form of capital. Though based on debt, and thus vulnerable to an unwinding of market positions as the euphoria of market upswings subsides, the securitized paper value of a given financial instrument retains a value of its own because it is the autonomous status of the value of securities from the capital they claim to manifest that enables these securities to exist autonomously as capital - not indefinitely, but long enough for dominant capital to generate record profits. The value derived cannot be equated to the value gained from direct exploitation of labour-power; it is, rather, a value derived through calculated speculation, via sophisticated high-frequency trading programmes which place multiple simultaneous bets on a representative sample of commodities and securities. This is simply a process of value creation, as a consequence of which money capital becomes the source of its own growth, expanding and contracting, leaving debt in its wake. Although orthodox Marxists claim that in commodity-producing societies value is generated only through commodified labour-power, if we accept the impure and uneven development of capitalism outside the capitalist economies of the West and the unconstrained growth of finance as a profitable alternative to manufacturing, it is clear that not only are the traditional 'modalities' of capital accumulation not central to the reproducibility of emerging market economies (Westra 2010: 182), but that the direct exploitation of labour is not (as Marxists assume) an ineliminable condition for creating surplus-value because trades in securities and financial derivatives always already take place under capitalist relations of power characterized by the general subsumption of human labour as a commodity for capital expansion.

However, the displacement of accumulation from production to speculation fails to eliminate the valorization problem for capital, and merely moves the problem to a higher and more problematic level with potentially more serious implications for the stability of financialized economies. For, if faith in the realization of future value begins to collapse because it is foreseeable that the real-economy basis to which the property titles correspond has eroded 
(Lohoff \& Trenkle 2012b: 1), then the stability of the wider system is placed in danger. The global (Western) financial crisis occurred because the mechanism required to postpone a structural crisis of valorization eventually failed, thus calling into question the viability of capitalism as a form of abstract wealth production in which only those commodities that augment value are conditionally produced. In April 2009 coordinated action between states convened at the G20 prevented a seizure of the global banking system from sending the world economy into freefall, but while Western governments managed to forestall an unwinding of securitized debt through expansionary monetary policy, higher borrowing, economic stagnation and rising inflation will eventually lead to demands for a rise in interest rates. In contrast with the US, where economic stimulus has enabled the financial system to recover temporarily by fuelling another bubble in the equity and bond markets, the fiscal response of policymakers in the UK and eurozone is to tighten fiscal policy in the vain hope of balancing national budgets - treating the vital support systems of capital (education, welfare, healthcare) as 'ballast' to be hauled overboard to offset the 'systemically relevant' needs of the financial sector: 'Above all else, what has to be prevented [...] is the collapse of the towering mountains of irredeemable payment promises. For that reason, most of the newly created fictitious capital flows back into the financial sector directly and less and less of it enters into circulation in the real economy' (Lohoff \& Trenkle 2012b: 3).

In earlier recessions the state returned the economy to growth by lowering interest rates and promoting increased borrowing, but the economic effect of lower interest rates has been muted by the fact that asset prices are overvalued due to counter-deflationary policies. As Palley argues, 'rather than increasing asset prices and generating a positive wealth effect on consumption as in the past [...] lower interest rates diminished the decline in asset prices that would otherwise have occurred' (Palley 2012: 133). Although falling demand is not the underlying cause of the present crisis, declining wages and debt are preventing Western economies from combating stagnation as households run out of money. Yet deficit reduction and fiscal tightening merely threaten deeper stagnation, exacerbating budgetary imbalances by reducing tax revenue.

To maintain the banking cartel that controls the fiat money system, the US economy has been 'abandoned to the competition' as the Federal state abandons responsibility for investment in national infrastructure (Garcia 2013). Global corporations 'with American names' may be competitive, argues Faux (2006: 190), 'but the US economy - the collection of workers, businesses and infrastructure that produces in America - is clearly not'. Although frustrated by deflationary counter-pressures in the advanced economies, the policy of 'simmering' inflation allows corporate-state elites to reinflate asset prices and monetize US debt at the expense of workers and international creditors. In this way inflation becomes a surrogate for economic growth while easing distributional conflicts (Krippner 2011: 140), but in inflationary credit 
expansions "wealth is transferred from the public in general to the earliest recipients of the newly created credit money. In practice, the earliest recipients are interest groups with the strongest political connections' (Boyapati 2011: 1). This is referred to as the 'Cantillon effect', after the eighteenth-century Irish-French physiocrat Richard Cantillon, who observed that expansionary monetary policies lead to a transfer of wealth from those who hold traditional assets to whomever is closest to the issue of new money, namely financial institutions with ties to the money-issuing bank. This is possible because the transfer of wealth in periods of inflation is concealed from a majority of the population and because rising prices create a 'general state of euphoria, a false sense of wellbeing, in which everybody seems to prosper' (Hayek 1970, cited in Boyapati 2011: 1). However, even harnessed to the market-distorting power of 'systemically relevant' banks that work alongside the Federal Reserve to support the US dollar, this strategy is unsustainable.

The US can delay dollar devaluation in the short term because it is still able to print the currency in which its debt and balance of payments deficit are denominated, and because investors in Asia and the Gulf are still committed to the US monetary system and believe the Federal government itself is 'too big to fail', which in turn enables the US Treasury to borrow privately issued bank money to finance the deficit without paying the equivalent price of an immediate decline in the value of the dollar. Yet a consensus is emerging that the US (and therefore the UK) is on a path to collapse because it has resorted to monetary expansion to manage national finances and simulate recovery without a corresponding structural adjustment of its economy (as occurred in Asia after 1998), or a formal correction in the value of its currency, fuelling anxieties among investors over long-term asset values. As one journalist observes, expansionary monetary policy (in place of structural reform) has created an addiction to central bank money that Western governments are reluctant to address:

Unconventional monetary policy is meant to work on the "hair of the dog that bit you' principle. By fighting a crisis caused by too much money with yet more money, the central bank hopes to restore the economy to a 'normally' functioning machine, at which point saner voices are meant to take over and a more sustainable form of growth establishes itself [...] Unfortunately, the near free money environment has gone on for much longer than anyone anticipated. What's more, we seem quite incapable of easing ourselves off the life support. Every time central bankers try, the economy stalls anew and they are forced to backtrack.

(Warner 2014b: 1)

The US and UK are not alone, or course, for as paper currencies worldwide decline in value against commodities and precious metals, all the major industrialized economies will be tempted to engage in competitive devaluation, adopting beggar-thy-neighbour monetary policies - including the 
eurozone and Japan. However, unlike the eurozone, which has imposed structural reform on states in the currency area (limiting sovereignty over fiscal policy), or Japan, whose debt is offset against its citizens' savings, the US and UK are constrained by unmanageable public and private debt. This, combined with low growth and historically low interest rates, has encouraged both economies to 'steal' growth from emerging markets, creating the risk of currency wars which always 'begin in an atmosphere of insufficient internal growth. The country that starts down this road typically finds itself with high unemployment, low or declining growth, a weak banking sector and deteriorating public finances' (Rickards 2011: 38).

As the world's largest debtor, the US is thus free-riding on the international monetary system, leveraging its trade deficit and debt as weapons to export inflation to emerging markets while exploiting the privileged status of the US dollar as the premier reserve currency to externalize and conceal its domestic economic and political contradictions. In the short term, argues Prasad (2014), the US-led banking cartel can continue to attract foreign investors as long as a 'delicate political equilibrium' is sustained - that is to say, as long as domestic holders of US securities retain their faith that the Federal government will not resort to hyperinflation. It can also even try to drive money capital into government-sponsored debt by reclassifying private bank deposits as 'paper investments', turning depositors' funds into potential bankruptcy disbursements as the primary instrument for bank 'bail-ins' in the next financial crisis (Schortgen 2014).

In the long term, however, these tactics are unsustainable, for once it becomes clear that the Federal Reserve can no longer guarantee liquidity (and as a result of rehypothecation and constraints on supply, lacks adequate physical gold to offset its balance of payments deficit and honour requests by central banks for repatriation of their bullion); once it becomes clear that monetary expansion and deficit spending are reaching critical thresholds, leading to unpredictable non-linear consequences (cf. Mishkin et al. 2013; Moran 2012); and once rival currencies acquire a larger share of central bank currency reserves, the status quo will become untenable and exit from the US dollar will accelerate - although this process will be chaotic and potentially catastrophic for the rest of the world since an unplanned reset in the value of the dollar would lead to revaluation in the value of all assets priced in dollars (except gold). To guarantee global liquidity in the next crisis, argues Rickards (2014), some form of top-down multilateral money creation based on the IMF's SDR facility may be necessary to prevent a disorderly restructuring of the global monetary system - that is, to put in place an alternative multilateral currency arrangement before investor confidence in the dollar evaporates and before non-Western economies move to conduct trade transactions in other currencies.

Yet some observers argue that foreign investors are already exiting longterm US debt - evidenced by the increasing purchase of short-term US Treasury liabilities since 2008 - and predict that the rate of foreign buying 
cannot keep pace with the rising rate of US debt issuance (Skarica 2011: 42), even if the appearance of status quo is maintained in the short term by suppressing gold through sell-offs of gold paper derivatives, extending the maturity of US Treasury securities already purchased by the Federal Reserve, or even prompting foreign investors to purchase dollar assets via 'cut-out' arrangements (e.g. Belgium), to create the impression that international demand is steady and prevent the dollar from sliding (cf. Mackenzie 2014). Above all, it is the appearance of a strong dollar that must be defended even if major surplus economies like China are seeking alternatives to the US bond markets and conducting major international trade transactions in their own currencies.

In the short term, therefore, the fragility of the international monetary system seems to ensure the paradoxical stability of the US dollar (Prasad 2014). Yet as debt-to-GDP ratios deteriorate and interest rates rise, the cost of servicing US debt is likely to rise to more than 30 per cent of Federal government spending by 2016 (Pento 2013a: 159), creating further instability in a bond market already massively overinflated by Federal Reserve asset purchases. Global monetary reset is likely to be accelerated by the decision of major energy producers like Russia, Iran or Saudi Arabia to cease trading in US dollars and accept alternative currencies for oil and gas exports, obliging central banks around the world to rebalance their reserves away from the dollar - though, as we shall see in Chapter 7, it is clear that Western security services will attempt to destabilize any state that tries to exit the dollar system early. Although it is unlikely that a direct hostile assault on the dollar would take the form of dumping US Treasury securities on the market, if transnational investors unload dollar assets, the Federal Reserve will be forced to raise interest rates to sustain competitive bidding for longer-maturing bonds (Rickards 2011; Tanous \& Cox 2011). ${ }^{8}$ Yet, as the US government itself must be aware, this is unlikely to sustain investor confidence indefinitely, leaving US corporate-state elites with three options, namely: (i) devaluation (creating price inflation and political instability in emerging markets which appear to offer investors alternative havens) (Bond 2007); (ii) suppression of the gold market through derivatives trading in 'paper gold' to defend the dollardenominated international payments system; and (iii) radical currency revaluation leading to the replacement of the defunct dollar with a new gold-backed monetary unit with variable global/domestic conversion rates to ensure the continuity of transnational class power and the preservation of plutocratic wealth.

\section{Conclusion}

As one study on the international monetary system argues, since 2007 'the West has been assailed by the longest-running crisis since the 1930s, hollowing out the natural ambitions of the countries that used to run the world, and 
weakening the natural pull of the US and European currencies' (OMFIF 2013: 3). In the new global economy capital is sovereign, and it is impossible for states to resist international pressure for a return to sound money as a means of payment and store of value for transnational investors. Capitalist sovereignty is contingent on the unconstrained global circulation of money capital, and as Goldner (2009: 1) rightly observes, it is the general pattern of capital to 'cheapen all commodities, including the universal commodity laborpower'. Since the recession of the 1970s, Western states have resorted to inflation to conceal distributional conflicts in the absence of robust economic growth, accompanied by financialization to compensate for declining profitability in the non-financial corporate sector. This has fuelled the accumulation of fictitious capital through an intensification of the debt relation and the development of new financial instruments to expand corporate balance sheets and satisfy demands for continually rising shareholder value, exaggerating price-to-earnings ratios. The primary threat to the economic future of the West is not the debt relation itself, however, but the liquidity fetish that has been the driving force of the credit cycle since the 1970s and which is destabilizing bond markets at the risk of devaluation or default. As Warner argues:

Monetary activism may have helped save the UK and the US from greater calamity after the financial crisis, but it only steals growth from the future and from others. One effect of loose money is currency devaluation, which might give a temporary boost but merely shifts the deflationary problem onto other states. This in turn produces a race to the bottom as each country attempts to outdo the other. Globally, it's a zero sum game.

(Warner 2014c: 2)

This zero-sum game will not harm global investors, particularly those with the foresight to invest in gold before it is remonetized, or exit bond markets before debt auctions fail. Those economies and corporate investors that do exit the dollar system at the earliest point are likely to become the leading players in a post-US-centric global economy (cf. Willie 2013), though monetary reset will cause massive capital flight and strip wealth from US consumers following the example of similar sudden economic adjustments in history, including Thailand, Russia, Argentina and Greece. This will mark the beginning of the end of a complex international monetary system centred on the US - a system that effectively disguises and suppresses its own volatility through continual expansion of the credit-debt nexus and the creation of evergreater asset bubbles to compensate for the political failure to address the accumulation crisis of Western financial capitalism. Given the irresistible force of changing global capital flows, however, monetary reset will also accelerate global economic rebalancing, potentially recreating the economic conditions for a (temporary) return to profitable accumulation as the economic centre of gravity in a post-US-centric growth system shifts towards Asia. 
Notes

1 Shiller defends the idea of (regulated) financial capitalism as a legitimate expression of the aggressive competitiveness of human culture, arguing that it 'creates a safe venue for power struggles without violence. Achieving such a system requires appropriate innovations that humanize finance [...] There is no known economic system that can perfect aggressive human impulses, but they can be softened' (Shiller 2012: 1). This may, of course, be true in a purely formal sense - that is, where business is viewed naïvely as a game driven by 'animal spirits' which must be 'tamed' without undermining profits. Yet the author is unable to conceptualize either the brutal origins of capitalist finance in primitive accumulation, or the symbolic violence of financial power as a destructive machine that creates fictitious value through a massive leveraging of debt and intensification of risk, with catastrophic human consequences when the system eventually collapses.

2 Although Hobson (2004) highlights the superior development of military technology in China in the thirteenth century.

3 See Middelkoop (2014). Figures valid for December 2013. In the US, the Federal Reserve now owns 12 per cent of US Treasury bonds. In the UK, where the national debt reached 99 per cent of GDP in 2014, the Bank of England has acquired 25 per cent of UK Treasury liabilities through its Asset Purchase Fund.

4 See moneyweek.com/prices-news-charts/oil. Rising oil prices carry geopolitical risks for the US, benefiting major energy exporters like Russia, which was able to pay off a large part of its national debt during the oil price boom of the 2000s. High oil prices also harm the global mining industry and the US oil industry by increasing the cost of exploration and extraction.

5 The US Federal Bureau of Statistics estimates that only 62.8 per cent of Americans of working age are in employment. See: data.bls.gov/timeseries/LNS11300000 (online data obtained 28 January 2014).

6 For a statistical breakdown of real poverty rates in the US, see www.povertyusa.org/ the-state-of-poverty/poverty-facts.

7 On the UK's unsustainable consumer debt, see Titcombe (2014). UK consumers possess 70 per cent of the credit cards issued in the EU, on which interest is charged at an average of 17.5 per cent.

8 Rickards (2011: 162) argues that if China, for example, wished to divest itself of dollar assets without drawing ire from the US and without threatening the value of its vast remaining holdings, it could simply switch from longer to shorter maturing bonds without reducing its holdings: 'shorter maturities are less volatile, meaning the Chinese would be less vulnerable to market shocks. This shift would also make the Chinese portfolio more liquid, vastly facilitating a full Chinese exit from Treasury securities.' The effect of this, he adds, would be like 'shortening the fuse on a detonator' (ibid.). 


\section{Towards a posthegemonic global growth system}

\section{Introduction}

Resolution of the crisis of neoliberal capitalism suggests two possible outcomes. The first points towards a reversal of globalization as growth in emerging market economies slows and the volume of world trade declines, leading to a fragmentation of the global economy and a return to economic nationalism. This outcome is possible, but unlikely, for four reasons. In the first place, although the momentum towards global economic integration has slowed during the global recession, IMF forecasts suggest that growth in emerging markets will average 5.0 per cent in 2015 - compared with 2.2 per cent among G7 nations (IMF 2014). ${ }^{1}$ Indeed, long-term forecasts suggest emerging market economies will continue to grow by an average of 6.7 per cent annually between 2013 and 2030, and will eventually account for around 75 per cent of exports (Roland Berger Consulting 2011), although this - as suggested in Chapter 5 - may not prevent Western economies attempting to 'steal' growth through competitive devaluation. Second, emerging economies are likely to remain attractive destinations for FDI despite the slump in global trade in the period 2010-14. Third, it is clear that in the new economic geography of regionalism corporations in emerging economies have the potential to reduce operating costs by locating labour-intensive stages of production in low-wage spatial units (Buckley \& Ghauri 2004), while benefiting from rising consumer demand as developing economies experience intensive urbanization and growing affluence. Finally, it is clear that emerging market economies have the option of reorienting their commercial strategies to take greater advantage of regional trading blocs aimed at facilitating a free flow of corporate investment between states within regional spatial contexts exemplified by the growing importance of ASEAN in South-East Asia or the Gulf Cooperation Council (GCC) in the MENA region. Regional organizations of this type are not counterhegemonic in any explicit ideological sense, given their political and commercial ties to the US and EU, which actively promote Western corporate interests by lobbying regional organizations in a formal or informal capacity - for example, the campaign to deny India full member status of APEC because this might tip the balance of power within 
the organization towards Asia (Sahoo 2012). Yet, regional organizations are multilateral in structure and outlook, seeking to facilitate corporate investment and drive economic growth across their respective regions rather than advance the sovereign interests of any single (proto-)hegemonic state actor.

A second outcome is more probable, therefore, namely a posthegemonic resolution of the crisis leading to new forms of capital restructuring and economic rebalancing in favour of emerging market economies, compensating for (yet potentially accelerating) the decline of the EU and North America as Western economic power is undermined by devaluation, rising debt, unemployment and capital flight. This may or may not herald a new post-Eurocentric 'global modernity', as Dirlik (2001) believes - particularly in view of the continuing dependence of China on the US and EU consumer markets (cf. Westra 2012). However, there is evidence to support the view that a recovery of global trade over the next two decades - and thus a continued globalization of capital - is contingent less on a recovery of the West to its former status than on the further penetration of and entanglement of households in emerging market economies by financial instruments and products as capital moves forward to escape its existing spatial and historical limits outside the advanced capitalist states of North America, Japan and Western Europe (Bryan 2012: 173; cf. Harvey 1982). ${ }^{2}$

What is certain, however, is that while sustained rapid growth was restored in Asia in the 'Golden Age' of post-war capitalism after 1945 (Garnaut 2013), exit from the accumulation crisis of the 1970s accelerated integration of emerging economies into the global financial system as non-Western corporations began to challenge the hegemony of Western multinationals for control of markets (Guillén \& Ontiveros 2012). In addition, it is clear that emerging economies have recovered far more rapidly after the recent financial crisis than the advanced economies, whose share of global GDP declined sharply from 57.6 per cent in the period 1986-2007, to 47.9 per cent in the period 2008-10 (Prasad 2012; cf. Marinov \& Marinova 2013). Assuming the stability of the world economy remains unaffected by rising geopolitical tensions between China, Russia and the US (see Chapter 7), global rebalancing points towards a multipolar growth system in which the Washington consensus will be increasingly challenged by posthegemonic/counterhegemonic regionalism. One of the clearest expressions of this phenomenon is the desire of South-East Asian governments to avoid a repeat of the humiliation experienced after the 1997 crisis when IMF support was made conditional on painful structural adjustment. This helps to explain the determination of East Asian economies to accumulate foreign exchange reserves as a hedge against turbulence and the trend in the region towards closer economic and financial integration (Wheatley 2013a; Ziltener 2012). ${ }^{3}$

In this chapter we examine the expansion of transnational capital in Asia and beyond, assessing the causes and consequences of globalizing capital outside the Lockean heartland as the world economy moves towards a multipolar growth system. The key question is not when the balance of 
geoeconomic power will shift, but whether the transition from a US-centred world economy will lead to rebalanced multilateralism (where global instabilities created by the imbalance between surplus and deficit economies are - if not fully resolved - then at least partially addressed), or fragmented regionalism (where interstate/interregional conflicts increase as corporations compete more aggressively for global share of emerging markets within regional accumulation regimes).

This leads to a secondary question, namely whether corporate-state elites in the Anglosphere are in a position to accept and adapt to reserve currency diversification, which will inevitably undermine their ability to delay necessary adjustments in global balance of payments and their associated capacity to coerce non-Western governments to orient their monetary policies in line with the dollar. As noted in the previous chapter, it is far from clear whether overleveraged economies living beyond their means can tolerate reserve currency diversification without resorting to defensive statecraft, increasing the possibility of volatility in currency markets and geopolitical conflict. As we shall see in the final chapter, the implications of posthegemonic regionalism and reserve currency diversification for world order are complex and unpredictable as the US struggles to cope with demands for global liquidity while disengaging from its role as 'provider of global security' in preference for an informal role in sustaining Western corporate influence in Eurasia, Africa and Latin America. Although the US has presided over a monetary policy of benign neglect for decades without having to restructure its fiscal or monetary system to satisfy financial markets, investor confidence in reserve currencies ultimately depends on whether they reflect economic fundamentals and/or whether the issuing nation has the fiscal capacity to sustain liquidity during crises. While there are no immediate threats to the dollar from either the euro or renminbi, as a component of global currency reserves the US dollar has declined relatively quickly from 70 per cent in 2000 to 62 per cent in 2013 (Wheatley 2013b).

Lin and Dailami ask whether the world is actually ready for economic multipolarity - not simply the decline of a US-centred world economy but a multilateral global growth system driven by emerging market economies:

Throughout history, paradigms of economic power have been drawn and redrawn according to the rise and fall of those countries best equipped to drive global growth and provide stimulus to the global economy. Multipolarity, meaning more than two dominant growth poles, has at times been a feature of the world economy. But at no time in modern history have developing countries been at the forefront of a multipolar economic system.

(Lin \& Dailami 2011: 1)

By 2025, they predict, six emerging market economies (China, Brazil, India, Indonesia, South Korea and Russia) will collectively account for 50 per cent of global growth, a development that will put pressure on the international 
monetary system. As these states 'pursue growth opportunities abroad and are encouraged by improved policies at home', they argue, 'emerging market corporations will play an increasingly prominent role in global business and cross-border investment, while large pools of capital within their borders will allow emerging economies to become key players in financial markets' (Lin \& Dailami 2011: 1).

The importance of this cannot be overstressed: not only does it highlight the potential threat to the petrodollar cartel, but for the first time in history it raises the possibility that non-Western state actors and corporations will assume a place 'at the helm' of the global economy as emerging market firms increasingly dominate their own industrial sectors. This will put additional pressure on the West to adapt to a multilateral framework for managing cross-border trade and investment - although Western elites will resist calls for a multipolar global financial regulatory regime until it becomes unavoidable. It will also place pressure on the West to support international development more energetically in response to growing North-South interdependency, particularly in view of the neoliberal argument that effective transnational governance depends on 'leveraging that interdependency to strengthen international cooperation and boost worldwide prosperity' (Lin \& Dailami 2011: 1).

From a critical IPE perspective, however, the expansion of the global economy and the movement of capital away from the West suggests a sustained period of 'poverty capitalism' rather than rising prosperity. As Heinrich argues, capitalist development in India and China

is at its very beginning [...] If in the course of the next few decades a middle class with purchasing power emerges in them - albeit comprising merely 20 to 30 per cent of the population, with the rest living in poverty, that alone would constitute a market of 600 to 700 million people, far larger than the expanded European Union.

(Heinrich 2007: 1)

More importantly, he adds, the "massive army of poor people [in Asia] ensures a stream of cheap labor for the decades ahead. For capital, all manner of things might become scarce in the 21st century, but cheap labor will not be among them' (Heinrich 2007: 1, emphasis added). In periods of low growth and intensified competition it is critical for corporate elites to pay attention to the costs of horizontally integrated multinational firms because commitment to particular sources of supply or demand of goods or services becomes more risky and expensive, encouraging businesses to switch production to cheaper sources of supply (Buckley \& Ghauri 2004: 84). While the capacity of corporations to generate high profits in the West is declining, rates of value augmentation are likely to increase globally as corporate actors shift their focus from depressed markets, leading investors to expand their presence in the Asia-Pacific region where the urban proportion of the population increased from 33 to 43 per cent in the period 1990-2011 (UNESCAP 2012), 
the majority concentrated in 'super-agglomerations' such as Shanghai, Mumbai, Kolkata, Manila, Bangkok and Jakarta - cities which, through a deepening global division of labour, have evolved into geoeconomic 'hubs' for the twenty-first century. ${ }^{4}$ This process is being driven not simply by state actors, however, but by the global and regional commercial strategies of corporate capital.

In what follows we assess the interrelation between regionalism, globalization and economic development, and examine the theoretical contribution of the new economic geography - an innovative sub-discipline of IPE concerned with the spatial reordering of the world in accordance with the shifting geoeconomic priorities of capital. Regional economies can be defined as 'synergyladen systems of physical and relational assets, and intensifying globalization is making this situation more and not less the case' (Scott \& Storper 2003: 579). Regions constitute an 'essential dimension of the development process, not just in the more advanced countries but also in less developed parts of the world' (ibid.), contributing to the 'global mosaic of regional economies' that cut across territorial boundaries, while extending the economic frontiers of capitalism beyond the core industrialized world (Scott 1998: 46-73).

Our primary concern is the geoeconomic logic of regional organizations and FTAs through which capital organizes trade and investment and exploits synergies between economies whose relations are determined by propinquity and proximity, in order to facilitate a more profitable allocation of capital in the wider global economy. Scholars working in this field of global political economy and economic geography are concerned primarily with the functional and political character of the new regionalism as a meso-level feature of global governance in a decentred capitalist world system driven by the competing pressures of globalism and statism. Central to this field of research is the inherent tension between the global multilateral trading system advanced by global agencies like the IMF and WTO, and the growing importance of regional formations as institutional mechanisms for maximizing corporate profitability.

\section{The economic geography of competitive regionalism}

Significant differences exist between the 'autarkic' regional blocs created by revisionist powers in the $1930 \mathrm{~s}$ in opposition to the global imperial power of the Anglosphere, and the competitive regionalisms of contemporary globalization (Telò 2007). Most important, perhaps, is the fact that present developments are a structural phenomenon of international relations in a globally integrated economy rather than a consequence of interimperial conflict: posthegemonic regionalism is an integral feature of globalization, which requires transnational corporate actors to coordinate their commercial strategies through trading blocs, customs unions and other regional organizations that mitigate the impact of trade liberalization while improving terms of trade for corporate entities seeking to grow and invest transnationally. 
Significant differences also exist between contemporary regional formations, particularly strong/closed supranational structures like the EU and weak/open intergovernmental trade agreements (Lane 2012). Liberal globalists theorize regionalization as one step in a logical progression towards a rules-based global capitalist economy managed by transnational and transregional governance structures; for realists, on the other hand, deepening regional projects are potentially incompatible with this vision because regionalization can also result in a zero-sum game between state-centred blocs that compete for market share (geoeconomic realism), consolidating specific roads to capitalism based on competing models of economic and cultural organization (Telò 2007: 10).

One example of this would be the geopolitical tensions between the EU and the new Eurasian Economic Union (EEU) under Russian patronage, which have contributed to the crisis in Ukraine. Although these tensions have been successfully leveraged and exploited by the US to sabotage Russia's deepening economies ties with the EU (see Chapter 7), realists are rightly sceptical of the cosmopolitan vision of global multilateralism, for while capital constitutes the dynamic and directionless force driving globalization - the real subject of a new global sociality - globalization is taking place in a world of nation-states and cannot be detached from geopolitics, not least the transnationally constituted agency of the Anglosphere. Indeed, it is unrealistic to expect militarized states like the US to forgo their hard-power advantage and relinquish their prerogative to engage in coercive diplomacy and/or direct intervention to achieve outcomes consistent with their geopolitical interests. Although many celebrate the rise of competitive regionalism in Asia, Africa and Latin America - highlighting the growth of both East-South and South-South cooperation and regional challenges to the Washington consensus (Bhattacharyya 2011; Smith 2011; Flores-Macías 2012; Broadman 2007; Wylde 2012; Pieterse 2011), Western economies will act to counter Russian, Indian and Chinese penetration of markets in the Balkans, the greater MENA region and Latin America. ${ }^{5}$

The rise of competitive regionalism and the emergence of new global growth poles in a decentred world economy require us to rethink the question of economic rebalancing from a critical perspective - that is, in terms of the contradiction between the means and conditions of accumulation where the 'necessary means to regulate and control the political basis of capital - the wage-labour relation - contradict the ability of capital to expand' (Smith 2008: 196). Capital reinforces spatial integration despite self-imposed geographical barriers. However, adds Smith, it is here that the contradiction of capitalist globalization becomes clear:

First, to the extent that capital escapes one set of spatial barriers, it reimposes them at a different scale. New supranational regions require political institutions to match, and the development of the EEC [European Economic Community] in particular owes much to this process. 
The new spatial fixity brings back the old contradictions in spatial integration and is no spatial fix. But more important the tendency toward the internationalization of capital is severely restrained by the necessity of the nation-state as a means of political control.

(Smith 2008: 196)

As argued in Chapter 4, the state form of capital has evolved in accordance with the internationalization of capitalist relations of power under US hegemony, hastening the growth and intensification of global governance although the synarchic capacity of the transnational capitalist state is distorted by asymmetric relations between powerful state actors who prefer 'governance with government' to supranationalism. For this reason, Brenner (2011) rejects geocentric interpretations of world order in contemporary global capitalism that posit a borderless world where states (and geography itself) no longer matter: spatial displacement leads to the creation of new spaces of production which are contingent on state fiscal, monetary and security policies, geographical contexts and labour conditions (cf. Harvey 1989).

As Brenner argues, critical social scientists must examine more closely how sociospatial configurations are rescaled rather than levelled through corporate globalization to ensure that the effort to 'transcend state-centric modes of analysis does not entail a denial of the national state's continued relevance as a major locus of political-economic regulation' (Brenner 2011: 103). The organization of state space and world space is being radically reformed, and the contemporary form of capitalist spatial organization is now increasely intertwined with 'historically specific patterns of uneven development insofar as it entails the systematic privileging of some locations, places, territories, and scales, and the marginalization and exclusion of others' (ibid.: 106). The result is a multiscalar reconfiguration of the world economy into a hierarchy of local agglomerations and regionally organized subnational/supranational scales which facilitate corporate trade and investment. There is little to be gained by extrapolating from the national-state to global-state form of capital when the complexity of mediating scales is determined by a wide variety of contingent criteria, for corporations employ spatially diverse market-seeking and asset-procurement strategies, operating through complex differentiated networks of subsidiaries and localized spatial monopolies which serve to increase 'specialization and localization to enhance the division of labour globally' (Buckley \& Ghauri 2004: 86).

Global economic restructuring, argues Brenner, heralds a 'new wave of deterritorialization and reterritorialization in which global socioeconomic interdependencies are being significantly extended in close conjunction with the establishment, or restructuring, of relatively fixed forms of capitalist sociospatial organization at diverse subglobal geographical scales' (Brenner 2011: 122). This leads not to one single scale becoming dominant but to dynamic changes in the relations between spatial scales, creating an 
institutional mosaic composed of multiple, partially overlapping institutional forms and regulatory configurations that are neither congruent, contiguous nor coextensive with one another' (ibid.: 113). As the advanced economies attract less investment, the driving force of the new economic geography is the inflow of direct corporate investment into emerging and transitional economies - 53 per cent of which flowed to East, South and South-East Asia between 2006 and 2011 (Iammarino \& McCann 2013). Although the majority of this FDI flows from advanced to developing economies ( 89 per cent), the decision by transnational corporations to locate production in developing and transitional economies is accelerating transfers of capital, technology and innovation from advanced to backward regions, rebalancing the global economy away from the old industrial engines of the US, EU and Japan.

As such, the 'flat earth' theory of global free trade popularized by liberal globalists is a fiction. On the contrary, removal of barriers to trade 'can actually make geographical proximity more rather than less important. Many economic activities benefit from co-location, whether for reasons of simple logistics, shared inputs, or benefits of face-to-face contact' (Iammarino \& McCann 2013: 12; cf. Arita \& McCann 2000). While managerial hierarchies and standardized procedures of global corporations function as 'distancespanning devices', the 'most robust and innovative flat networks are disproportionately local' (ibid.: 13). The implications of this critique can be understood more clearly if we consider the economic logic of regional trading blocs, through which corporate and state actors negotiate terms of cooperation to manage the pressures of globalization in a post-Fordist capitalist system characterized by a persistent tension between multilateralism and regionalism - that is, between demands for global economic integration and the consolidation of market share on the one hand, and regional economic integration on the other. The growth of regional trade agreements is a less familiar dimension of neoliberal globalization, and debate over their role in the global economy raises familiar divisions between orthodox economic theory and critical political economy.

For neoliberals the formation of regional trade agreements is explained in terms of the "unambiguous gains to firms and consumers in founding member countries. Unambiguous gains from trade bloc entry lure countries to enter the bloc which results in the growth of bloc. This growth then generates gains to existing member countries' (Cumberworth 1996: 3), although there is some debate over the optimal size of trading blocs for maximizing returns and their welfare implications for global growth (Krugman 1991; Deardorff \& Stern 1994). As one WTO economist argues, regionalism represents 'a challenge because [regional trade agreements] can result in trade and investment diversion leading to higher welfare costs for non-participants; an opportunity because RTAs may create regional dynamic forces in favour of freer trade which, in turn, can generate important welfare benefits for the rest of the world' (Puche 2000: 123). Completion of the Uruguay Round of trade negotiations in 1994 was intended to create a single global market - albeit without 
universal regulatory convergence; yet capitalist globalization has simultaneously accelerated the development of regional trading blocs because trade among already existing ('natural') trading partners has intensified at a faster pace because regional blocs represent "safe havens" for many smaller countries that [can] not afford a "wait and see" strategy in the international arena" (ibid.: 124).

From a critical IPE perspective, on the other hand, the development of regional trading blocs reflects both the uneven development of global capitalism as a world system and the shifting dynamics between advanced and emerging market economies in a decentred global economy as states grouped within overlapping regional blocs and coalitions of states (NAFTA, EU, ASEAN, EEU, GCC, etc.) become the principal actors in the world economy (Switky 2000: 26). Regional economic integration can be understood either as a one-off event leading to a static outcome, or as a dynamic process that generates its own momentum (the 'spillover effect'), but the economic logic of regionalism is identical in both instances, namely to articulate modes of regulation consistent with the political economy of corporate capital. That is, in a global economy characterized by uneven development, in which the multilateralism of the post-war era under US leadership is disintegrating into posthegemonic regionalism, regionalization provides a post-Fordist solution to the demand from transnational corporations for both flexible production techniques and a flexible deployment of labour and capital within trading blocs/customs unions which constitute a step towards the reconstruction of the capitalist state at a regional and interstate level (Michalak 1994: 44), separate from yet coextensive with the state form of transnational capital discussed in detail in Chapter 4. The 'tension between multilateralism and regionalism', argues Michalak, has 'contributed to the international instability and long-term crisis of capitalism. However, the exact nature of the emerging new relations is not entirely clear' (ibid.).

What is clear is that multilateral trade liberalization and regionalization constitute two contradictory manifestations of the same basic tendency towards overaccumulation in capitalism, the function of which is to ensure the uninterrupted 'expansionary reconstruction of the capitalist mode of production' (Michalak 1994: 50). In theory, regional trading blocs should act as a hindrance to the freedom of global corporations to exploit differences in tax regimes and financial regulations between national economies, but the opposite is in fact the case: regional trading blocs allow corporations to shelter behind protectionism and thus should be understood as an attempt to 'reinstate national regulation on a continental scale' (ibid.: 55). The reality is that transnational corporations are far more regional than global in their spatial extent, which Michalak attributes to the desire of transnational corporations to enjoy the best of both worlds by exploiting the 'economic advantages and flexibility of large markets as well as the protection afforded by regional trading arrangements' (ibid.: 57). This reveals not only the weakness of neoliberal trade theory, but the economic reality of strategic trade intervention as 
a means for corporate-state actors to manage trade relations via participation in regional blocs that contradict laissez-faire - a tendency already present in the rise of the transnational corporation as the principal organizational form of oligopolistic capital.

In the search for value, transnational corporations also exploit political linkages and superior economic-cultural intelligence that pertain within regional contexts for commercial advantage. Intraregional cross-border integration allows transnational corporations to develop differentiated networks of subsidiaries sensitive to local market conditions. Although regional formations may lack geographical contiguity and coextensivity, there is evidence to suggest that capital benefits from propinquity and proximity in the organization of production and perennial search for value, and that global strategies may actually yield lower rates of profit. Cross-border integration within and between corporate firms depends on the formation of differentiated networks of suppliers and subsidiaries which must adapt to the simultaneous (and potentially contradictory) pressures of global integration and sensitivity to local market conditions (which in turn depend on the type of cross-border investment involved and types of commodity being produced). Yet propinquity of production and superior geographical and cultural intelligence allow corporations to take advantage of the higher intensity of exchange between neighbouring countries (Ziltener 2012: 98), to obtain information on rivals and reduce aggregate risk in ways that are simply not possible in global markets.

This reveals the underlying logic of regional trading blocs, namely to allow capital to gain preferential access to foreign markets and maximize commercial relations with states that are also members of the same regional entity. Although exclusive regional formations hinder global multilateralism by containing trade within closed regions and/or reducing global capital flows, they advance trade by consolidating markets at a regional level and promoting intraregional homogeneities which promote economic and financial integration. This process is well established in the EU and needs no elaboration here (see Matousek \& Stavárek 2012), but developments outside Europe suggest that regional financial integration is emerging as a strategy for diversifying and sharing risk, and for maximizing asset returns. Lower transaction costs follow integration of financial markets at every spatial level, increasing demand for assets, while encouraging higher levels of risk diversification. This happens, argues Martin, because a 'decline in transaction costs increases demand for assets in the area, so that the effective size of the market is enlarged' (Martin 2011: 20). The tendency towards financial market segmentation, he adds, "means that there is a financial home market effect favourable to large markets. Both regional and financial integration means that smaller and poorer countries gain. The greater the difference in size and development among countries, the greater is the gain' (ibid.). In a broader economic sense, regional integration allows small economies to counterbalance dominant players such as Germany in the eurozone, although states like Germany can 
exploit their leading position to advance their own national economic and foreign policies (Bulmer 2013).

\section{The challenge of emerging market economies}

Attempts to theorize and explain the present transformation of the global economy highlight different aspects of the process. For some authors, the main development is the rise of Asian regionalism, centred on China and ASEAN (Katzenstein 2006), but also the broader Asia-Pacific community (APEC) within which China must compete for influence with the US. For others the most important development is the transregional rise of emerging market economies (notably the BRICS) and the challenge these present to corporate interests linked to the advanced industrial economies of the West (Marinov \& Marinova 2013; Nayyar 2013; Desai 2013; Guillén \& Ontiveros 2012). For still others, the main issue is the decline of Japanese pre-eminence in Asia as one corner of the 'old Triad' and its replacement by China, South Korea and other leading emerging market nations, which along with the US and the EU comprise three opposing blocs in a global political economy (McAllister \& Sauvant 2013). Finally there are those who argue that, in the absence of real structural reform, the US itself is in terminal decline and can no longer compete in a posthegemonic world system (Janszen 2010; Roberts 2010; Robert \& Maruschzik 2013), or at least cannot do so without falling back on its traditional hard-power advantage to undermine rivals through the projection of coercive financial and military power (Nazemroaya 2012; Petras \& Veltmeyer 2011). We shall deal with this latter issue in the final chapter. In what follows here we examine the rise of new growth poles in the global economy and assess the scale of the challenge presented by emerging markets to the economic hegemony of the US, Europe and Japan.

For some critical international theorists, the global financial crisis is evidence of a trend towards deglobalization, signalling the end of the Washington consensus. Bello (2013) is representative of this view, arguing that the source of the crisis lies in the complex interdependence of a hyperglobalized economy that depends on a structural imbalance between indebted consumer economies in the West and 'chain-gang' export economies in the East (cf. Cox \& Lee 2012; Westra 2012). Bello suggests that while there are pressures within China to disentangle its economy from the US-China nexus forged in the 1990s, the most powerful collective lobby in China (state technocrats, entrepreneurs, party-state managers, foreign investors, etc.) is opposed to relying on domestic demand to fuel future growth. On the other hand, however, he recognizes that the triumph of austerity in the US and EU will 'surely eliminate these two areas as engines of recovery for the global economy' (Bello 2013: 57), forcing China to consider alternatives to export-led growth potentially decoupling the People's Republic from the present framework of globalization. 
However, while there is no question emerging economies are beginning to challenge Anglo-American and Japanese power in the global economy, and that relative growth rates between the West and emerging markets are sharply divergent, the evidence suggests that since the Asian crisis cyclical interdependence has intensified (Derviş 2012; cf. Kose \& Prasad 2010), and forecasts of the death of neoliberalism are overstated. As suggested in Chapter 1, it is precisely through cautious adaptation to globalization that previously authoritarian states such as Brazil, China, South Korea, Indonesia, Russia and Mexico have progressed out of isolation and stagnation: although 'varieties of capitalism' are relevant in a cultural-geographical sense, and although capitalist globalization has been marked by a parallel acceleration of regionalism, adaptation to an economic system forged in the West has enabled emerging market economies to develop towards convergence with the US and EU (measured in terms of purchasing price parity) as new growth poles in the global economy. Pressure to satisfy the rising expectations of their own population is sufficient in and of itself for emerging market leaders (revisionist or not) to adapt to the discipline of global markets - even at the price of generating unrealistic expectations of exponential growth in the face of increasing energy scarcity (Klare 2008).

As Guillén and Ontiveros argue, although there is no doubt that the crisis of neoliberalism 'fundamentally challenged the assumptions and institutions that underpinned the growth of the global economy in the second half of the twentieth century including the roles of fiscal and monetary policies, the welfare state, and international monetary cooperation' (Guillén \& Ontiveros 2012: 16), there has been a failure in any meaningful sense to challenge, discredit or modify the growth-oriented market ideology of capitalism. While status competition and conflict over scarce resources are set to increase as global convergence proceeds (Davies 2012), there is little indication that the subordination of human labour-power and creativity to the process of expanding value or the subsumption of the biosphere to the requirements of capital are in general retreat. ${ }^{6}$

It was suggested in the last chapter that the future growth prospects of the West have been diminished by the negative consequences of financialization. Developments in the US and UK are particularly concerning for, in contrast to the eurozone, where officials have at least revealed the extent of the crisis in the 'Club Med' states, Anglo-American elites have failed to address the constraints of the FIRE (finance, insurance and real estate) economy and the stagnation of investment, as consumption (fuelled by low interest rates and increased personal debt) once again begins to take off (Warner 2014a).

In sharp contrast to the stagnation of the advanced, high-income economies of the West, emerging market multinational corporations in the Asia-Pacific region lie at the centre of the shift in the distribution of global economic power. In contrast with the post-1945 period when capital flowed primarily between developed economies, the transition towards a posthegemonic global economy is leading to the growth of FDI between core and emerging market 
economies and an intensification of trade between economies in the global South (cf. Bhattacharyya 2011; Broadman 2007). By 2010 multinationals in emerging market economies already accounted for 29 per cent of global corporations, with the highest number in China (Guillén \& Ontiveros 2012: 27). By 2030, more than 50 per cent of 'cumulative foreign direct investment will be accounted for by emerging market multinationals, and half of the Fortune Global 500 firms will be emerging market multinationals'. Many of these firms, which invest to acquire market access and procure resources, brands and technologies, 'grew big in [their] domestic market and are now seeking to expand their selling opportunities by making greenfield investments and acquisitions abroad' (ibid.). This expansion of emerging market corporate power is due not only to investment strategies, but to the experience of capitalist development in developing regions which employ local forms of finance to bolster growth regimes against the backdrop of financialization in the West, and which benefit from a global division of labour as capital secures the expansionary reconstruction of new sources of accumulation on a transnational basis.

In Chapter 5 it was noted that the crisis of accumulation in state-democratic capitalism in the 1970s led to a spatial expansion of trade and FDI in regions where development has consistently lagged behind the West. The internationalization of capitalist relations has led to an acceleration of modernization in non-Western economies, which are less constrained in their capacity to adapt to change, in contrast with Western economies which initiated the process of globalization but find it difficult to adapt to new standards and processes in the global economy. This phenomenon was originally theorized by Trotsky (1932) in the 'law of uneven and combined development', which Jan Romein reformulated as the 'law of the handicap of the head start', according to which those states at the forefront of economic modernization are rarely able to sustain their lead when confronted by competitors who import capitalist relations of production and exploitation and learn from the mistakes of pioneers (Van der Linden 2007). ${ }^{7}$ This phenomenon is evidenced dramatically by the rapid economic modernization of East Asia following the spectacular rise of Japan, which not only benefited from emulating and adapting production techniques developed in Europe and America, but which (like West Germany) took advantage of defeat and reconstruction under the US security umbrella to completely rebuild its economy. Trotsky originally defined uneven and combined development with reference to the supersession of England as the world's premier economy in the interwar period:

Although compelled to follow after the advanced countries, a backward country does not take things in the same order. The privilege of historic backwardness [...] permits, or rather compels, the adoption of whatever is ready in advance of any specified date, skipping a whole series of intermediate stages. Savages throw away their bows and arrows for rifles all at once, without travelling the road which lay between those two weapons in 
the past. The European colonists in America did not begin history all over again from the beginning. The fact that Germany and the US have now economically outstripped England was made possible by the very backwardness of their capitalist development [...] The development of historically backward nations leads necessarily to a peculiar combination of different stages in the historic process. Their development as a whole acquires a planless, complex, combined character.

(Trotsky 1932: 26-27)

The internationalization of capitalist social relations led to the supersession of the US by Japan and West Germany as exporting nations - followed by South-East Asia in the 1980s and China in the 1990s. Capital accelerated economic development and accumulation, although the 'forces that have made East Asian capitalism so dynamic for so long have inevitably brought [...] challenges. The continuous process of capital accumulation and the perennial reconstitution of markets as the principle of the economy have unleashed constant political, demographic and economic pressures' (Walter \& Zhang 2012: 3; cf. Bond 2007).

For Avineri, the economic 'advantages' of backwardness theorized by Trotsky can be summarized in the following schematic model:

1 backward societies are subject to exogenous sources of change through interaction with developed societies;

2 the effect of this interaction for the backward society is traumatic;

3 the effect of this interaction leads the backward society to emulate those features of the developed economy that make it advanced;

4 emulation allows backward economies to adopt ready-made models allowing them to skip various stages of societal modernization and technical innovation;

5 this accelerated telescoping of development creates dissonance/ pathologies between pre-modern and modern development forms; and

6 the result is 'uneven and combined development' - a non-uniform and potentially combustible process (Avineri 1977: 70-73).

Trotsky's analysis was based on the unique historical experience of Russia, a backward state that did indeed succumb to the contradictory and combustible combination of archaic and modern forms in 1917, leading eventually to Trotsky's exile and the rise of Stalin. However, notwithstanding the flawed brilliance of Trotsky's incomplete attempt to lend theoretical rigour to the concept of 'permanent revolution', it is the assumption of accelerated development that really matters, for while the state form of capital was fundamental to the postcolonial experience of the global South in the twentieth century, the primary consequence for non-Western societies of prolonged exposure to empire is that 'capitalism in the West [has] had the long- 
term effect of transforming backward societies in a direction historically unprecedented' (Avineri 1977: 79). ${ }^{8}$

In East Asian economies, in particular, this process has been phenomenal, rendering the Asia-Pacific region the most important theatre of global corporate investment as emerging market corporations develop their physical and intellectual infrastructure and scale the hierarchical ladder of the world's most important companies, accounting for 41 per cent of global cross-border investment in 2012 (Guillén \& García-Canal 2013: 4). It is not only emerging market transnational corporations in Asia that have grown in recent decades, but also those in Latin America, Russia, India and the Middle East - regions where cooperation and collusion between state and corporate elites help to shield the latter from the market pressures that force many Western nonfinancial corporations to concentrate on short-term market results as a means to deliver shareholder value.

However, while combined and uneven development of global capitalism intensifies the trend towards 'co-existing multiplicity' in world markets, turning the 'descriptive fact of unevenness into a germ of interactive mutation' between constituent elements in the capitalist world system (Rosenberg 2013: 583), emerging economies are never fully immune from what Trotsky termed the 'whip of external necessity', namely the violence of financial and monetary dislocation originating in the metropole which has intensified since the Federal Reserve initiated quantitative easing in 2009, destabilizing regional economies such as Turkey, Egypt, Brazil, Iran, Indonesia, Kazakhstan and Russia. While economic fundamentals favour emerging economies, their financial and monetary stability are also undermined by the absence of recovery in the West, as Western governments 'combine vast handouts to the banks with austerity for the masses [...] promoting growth and job-creation is always linked to so-called "structural reforms", a euphemism for the destruction of all forms of economic security for workers' (Grey 2013: 1). Austerity depresses demand for imports from emerging markets, which in turn reduces the capacity of emerging market corporations to drive growth and recovery in the global economy. In addition, it is clear Western central banks are content to export deflation via quantitative easing - a monetary version of 'currency war' where stimulus enables central bankers to counter falling prices in their own economies by exporting deflation to less developed regions of the global economy, adding to concerns about financial resilience in emerging markets (Hooy et al. 2013; Devereux \& Yetman 2011).

Yet emerging market corporations are still able to leverage backwardness to their own advantage, adapting ready-made models which allow them to skip specific stages of modernization and innovation, for the rise of emerging economies and regions in the capitalist periphery is also driven by the chaotic, risk-prone nature of corporate investment in developing regions which lack the historically matured finesse of Western financial capital as a coercive lever of power. In contrast with Western multinationals, 'emerging market multinationals started their international expansion lacking proprietary technology 
and strong brand reputations, so they had to compete with different weapons' (Guillén \& García-Canal 2013: 13). In addition, relative 'scarcity of resources such as capital or skilled labor invited emerging market multinationals to innovate, to make it possible to accomplish more with less. They turned their disadvantages into advantages' (ibid.).

Central to emerging market corporate success is a willingness to take greater risks, and to adapt to and embrace chaos by learning and profiting from adverse institutional environments, a pattern suggested by the spectacular rise of East Asian corporations such as Samsung and Acer. Adapting to chaotic conditions in their own domestic economies is understood to enable such emerging market corporations to gain 'firm-specific capabilities' which can then be applied in foreign markets to achieve superior performance in the global economy, suggesting important lessons for less flexible transnational corporations in the West still struggling to exit the global recession (Guillén \& García-Canal 2013: 110, 169):

The development of emerging-market firms into a potent force for globalization in their own right will have important implications for crossborder capital formation, technology generation and diffusion, and financing of commercial activities. A number of innovative and dynamic emerging-market firms are on a path toward dominating their industrial sectors globally - much in the same way that companies based in advanced economies have done over the past half century. Many emergingmarket firms have already begun overtaking their advanced-country competitors in terms of the priority accorded to developing innovative technologies and industrial processes, with 114 firms from emerging economies ranking among the top 1000 firms worldwide by $R \& D$ spending as of 2009 , twice as many as five years earlier.

(World Bank 2011: 5)

This is in large part due to the determination of developing economies in Asia to catch up with Japan and the West, but it is also due to the expansion and intensification of economic transmission channels between developed and emerging market economies, both of which now constitute 'growth poles' in the global economy supported by new concentrations of financial capital.

In a World Bank study of the multipolar economy, a 'growth pole' is defined as any 'economy whose domestic growth helps drive the growth process in other economies' (World Bank 2011: 16), in other words, an engine of capital accumulation. The term 'growth pole' was initially used to refer to 'agglomerations of firms or industries in which growth is concentrated and that had linkages to each other and to peripheral firms. Since then, the term has been applied to an increasingly varied set of related concepts, with "growth pole" quickly taking on a spatial or geographic dimension' (ibid.). The idea of growth polarity has since been 'extended to the global scale while simultaneously becoming somewhat enmeshed with the concept of polarity 
(sites of geopolitical/geoeconomic power) being developed in the international relations literature'. This, it is argued, 'reflects the intuitive idea that geopolitical influence stems ultimately from economic size' (ibid.).

A growth pole entails a complex series of economic transmission channels, the most important of which is scientific-technological progress as a 'spillover' effect (technology transfer). Transmission channels are flows of knowledge which operate through finance, trade and labour migration as well as direct transfers of physical and human capital. Scientific and technological innovation have always functioned as engines of productivity growth in capitalist economies, but their diffusion to emerging markets economies - in addition to FDI in physical and human capital, is understood to be the primary reason for the growth of productivity and income per capita in developing regions of the global economy. However, it is also imperative to consider other proximate factors such as capital accumulation, population, physical capital, education and health, as well as structural factors like political institutions and geography (World Bank 2011: 22). As Table 6.1 shows, whereas advanced economies were drivers of growth in the last century, this is changing: 'Using a measure of polarity that captures growth spillovers via trade, finance, and technology channels - defined as a country's multidimensional polarity

Table 6.1 Multidimensional polarity index, 2004-08 average

\begin{tabular}{lcllll}
\hline Economy real index & \multicolumn{3}{l}{ Economy $H B S$ index } & \multicolumn{2}{l}{ Economy PPP index } \\
\hline China & 26.20 & Euro area & 47.34 & China & 63.70 \\
US & 20.33 & China & 41.54 & US & 51.26 \\
Euro area & 10.86 & US & 30.51 & Euro area & 40.15 \\
Japan & 5.59 & Russia & 25.60 & Japan & 28.15 \\
UK & 5.51 & Canada & 22.61 & Russia & 26.02 \\
South Korea & 5.41 & UK & 22.49 & South Korea & 24.57 \\
Russia & 4.79 & South Korea & 20.49 & UK & 24.01 \\
India & 4.62 & Australia & 20.26 & India & 23.38 \\
Singapore & 4.30 & Brazil & 19.48 & Singapore. & 22.95 \\
Canada & 4.08 & Norway & 19.25 & Canada & 22.92 \\
Australia & 3.27 & Saudi Arabia & 19.18 & Saudi Arabia & 21.33 \\
Malaysia & 3.12 & Turkey & 19.17 & Turkey & 21.33 \\
Turkey & 3.07 & India & 19.14 & Mexico & 21.27 \\
Mexico & 2.94 & Singapore & 19.11 & Malaysia & 21.19 \\
Saudi Arabia & 2.94 & Poland & 18.76 & Australia & 21.14 \\
\hline
\end{tabular}

Source: World Bank 2011: 20

Note: HBS = Harrod-Balassa-Samuelson measure; PPP = purchasing price parity. Real, HBS and PPP-adjusted indexes indicate growth rates calculated from, respectively, GDP data in real 2000 US dollars, nominal local currency converted to US dollars at current exchange rates and deflated by US prices, and 2005 international PPP-adjusted dollars. 
index - the downward trend in the indexes of large advanced economies is evident' (ibid.: 19). ${ }^{9}$

Between 1997 and 2003 emerging market cross-border investment through merger and acquisition (M\&A) deals equalled $\$ 189$ billion (4 per cent of total M\&A activity in the period) (World Bank 2011: 5-6). Between 2004 and 2010 , however, this figure increased to $\$ 1.1$ trillion (17 per cent of the total). Since 2003, roughly 5,000 firms 'based in emerging markets have established a global presence through 12,516 green-field investments of $\$ 1.72$ trillion' (ibid.). In addition, more than a 'third of FDI inflows to developing countries now originate in other developing countries: of the 11,113 cross-border M\&A deals announced worldwide in 2010, 5623 [...] involved emerging market companies, either as buyers or as takeover targets by advanced-country firms' (ibid.). Indeed, whereas the global financial crisis led to a 28 per cent fall in emerging markets' outward investment in 2008-09, comparatively 'this deterioration was considerably less than the almost halved FDI outflows from developed economies in 2009 vs. its level in 2008' (Marinov \& Marinova 2013: 6). Most resilient among emerging markets (despite the negative inflationary effect of US monetary policy) were the BRICS, which accounted at year-end 2011 for more than 70 per cent of cumulative FDI from emerging market economies (ibid.), and 28 per cent of global outward FDI in 2010 (Bertoni et al. 2013: 47; cf. McAllister \& Sauvant 2013). While high-income nations are 'only gradually' recovering from the financial crisis, despite slowing in 2015 emerging market economies

swiftly returned to their fast pre-crisis growth trend. China was one of the first economies to emerge from the crisis, and it returned quickly to around 10 per cent growth. India experienced a stronger contraction, but also attained more than 10 per cent growth in 2010, and the government is putting in place an ambitious new Five Year Plan [...] to keep growth at that level. Latin America sharply rebounded in 2010, after contracting sharply in 2009. Even Sub-Saharan Africa is expected to return quickly to almost 6 per cent annual growth, similar to its performance in the years before the crisis.

(World Bank 2011: 2)

This does not mean - as Bello (2013: 119-36) correctly argues - that China or the BRICS economies can save the world from economic depression, or that a new dawn of East-South/South-South cooperation will suddenly overwhelm the West. However, there is every indication that global economic rebalancing will have geopolitical consequences as older rivalries and dependencies between the West and global South are challenged by the growing assertiveness of emerging economies, changing patterns of global growth, changing patterns of cross-border trade and investment, while generating new forms of economic cooperation that go beyond the older structures of asymmetric domination and dependency inherited from the imperial era. 
Table 6.2 Share of world population and global GDP, 1950-2008

\begin{tabular}{lrrrrrrr}
\hline & 1950 & 1962 & 1973 & 1980 & 1990 & 2001 & 2008 \\
\hline World population & & & & & & & \\
Asia & 55.5 & 52.2 & 54.6 & 55.5 & 56.6 & 57.3 & 57.4 \\
Africa & 9.0 & 9.5 & 10.1 & 10.8 & 12.0 & 13.5 & 14.6 \\
Latin America & 6.5 & 7.3 & 7.8 & 8.1 & 8.4 & 8.6 & 8.7 \\
Developing countries & 67.0 & 69.1 & 72.5 & 74.4 & 77.0 & 79.4 & 80.7 \\
Industrialized countries & 22.4 & 20.7 & 18.3 & 17.0 & 15.2 & 14.0 & 13.3 \\
Eastern Europe/former & 10.6 & 10.3 & 9.2 & 8.6 & 7.8 & 6.6 & 6.0 \\
USSR & & & & & & & \\
Total & 100 & 100 & 100 & 100 & 100 & 100 & 100 \\
Global GDP & & & & & & & \\
Asia & 15.6 & 14.9 & 16.3 & 18.3 & 23.3 & 31.0 & 38.0 \\
Africa & 3.8 & 3.5 & 3.4 & 3.6 & 3.3 & 3.2 & 3.4 \\
Latin America & 7.8 & 8.1 & 8.7 & 9.8 & 8.3 & 8.2 & 7.9 \\
Developing countries & 27.1 & 26.6 & 28.4 & 31.7 & 34.9 & 42.5 & 49.4 \\
Industrialized countries & 59.8 & 59.8 & 58.7 & 56.4 & 55.4 & 51.9 & 44.2 \\
Eastern Europe/former & 13.0 & 13.6 & 12.9 & 11.9 & 9.8 & 5.6 & 6.4 \\
USSR & & & & & & & \\
Total & 100 & 100 & 100 & 100 & 100 & 100 & 100 \\
\hline Sourc: Naygr & & & & & &
\end{tabular}

Source: Nayyar 2013: 50

Nayyar (2013) theorizes the approaching transformation of the global economy as a long-run dialectical process, focusing on the end of a long period of divergence, where Asian, African and Latin American economies lagged behind the West due to the asymmetries of political and economic power created by the experience of colonialism and deindustrialization in regions governed by European empires; and the beginnings of convergence, as developing economies began to close the gap, reflected in changing patterns of global GDP (see Table 6.2, figures adjusted for purchasing power parity). While relative levels of development in Asia and Europe in the eighteenth century were broadly similar, the decline of the 'rest' from 1820 to 1950 led to sharp asymmetries between European and non-European societies (specifically in Asia, where the share of global GDP declined from 36 per cent to 16 per cent) (Nayyar 2013: 20; cf. Amsden 2001). The subsequent coercive integration of Latin America, Asia and Africa into the European colonial trading system, a process stimulated by capital outflows from Europe and increased flows of migration, set in motion a process of transformation where uneven development eventually led to reduced asymmetries, with developing countries' share of global GDP reaching 35 per cent by 1990 (Table 6.2).

If these data are adjusted to account for present market value, however, a different picture emerges (see Table 6.3). It must be stressed that while average 
incomes in the developing world remain a fraction of those in industrialized nations, average incomes as a measure of GDP per capita in the West are exaggerated when compared with the actual distribution of wealth and income in the last two decades. This point is stressed by Saez (2013: 7), who notes that over the period 1993-2012 average incomes in the US grew by 17.9 per cent, while the income of the top 1 per cent grew by 86.1 per cent. During the period of 'economic recovery' in the EU and US (2010-12), the fraction of total growth captured by the top 1 per cent rose to 95 per cent, while real income growth for the bottom 99 per cent stagnated at 0.4 per cent. ${ }^{10}$

Inequality in the UK is, by comparison, lower, with estimates suggesting that in the period 2008-10 the top 1 per cent of British society possessed 13 per cent of national wealth (including pensions), compared with 44 per cent for the top 10 per cent, 62 per cent for the top 20 per cent, and 10 per cent for the lower 50 per cent (Hills \& Bastagi 2013: 26). Yet the most important feature of economic statistics is the direction of trends: on the one hand, growth rates in Asia from 1991 to 2008 averaged 6.5 per cent, and in developing states as a whole the equivalent figure was 5.5 per cent. This compares with 2.2 per cent in industrialized countries, where growth collapsed between 2008 and 2011 to -0.8 per cent (Nayyar 2012: 68-69); on the other hand, the global share of GDP of developing countries has effectively doubled since 1970, suggesting an historic process of economic convergence driven by the determination of Asia and Latin America to overcome relative backwardness through coordinated state intervention, state-managed financial architectures, controlled labour markets and basic welfare provision (cf. Walter \& Zhang 2012: 17). As we have seen, the significance of backwardness was identified by Trotsky, but it was also grasped by Gerschenkron (1962), and while Gerschenkron's model has many limitations, its 'generalizations from history [...] provide analytical insights into how a mix of ideology and institutions, or economics and politics, might foster success in countries which are later-comers to industrialization' (Nayyar 2013: 70).

Table 6.3 GDP and GDP per capita in developing countries and the world economy (in current prices and at market exchange rates)

\begin{tabular}{|c|c|c|c|c|c|c|}
\hline Year & $\begin{array}{l}\text { Developing } \\
\text { countries } \\
\text { GDP } \\
\text { (US\$ } \\
\text { billion) }\end{array}$ & $\begin{array}{l}\text { World } \\
\text { GDP } \\
\text { (US\$ } \\
\text { billion) }\end{array}$ & $\begin{array}{l}\text { GDP of } \\
\text { developing } \\
\text { countries } \\
\text { as \% of } \\
\text { global } \\
\text { GDP } \\
\end{array}$ & $\begin{array}{l}\text { Developing } \\
\text { countries } \\
\text { GDP per } \\
\text { capita } \\
\text { (US\$) }\end{array}$ & $\begin{array}{l}\text { Industrialized } \\
\text { countries } \\
\text { GDP per } \\
\text { capita } \\
\text { (US\$) }\end{array}$ & $\begin{array}{l}\text { Developing } \\
\text { countries GDP } \\
\text { per capita as \% of } \\
\text { industrialized } \\
\text { countries GDP } \\
\text { per capita } \\
\end{array}$ \\
\hline 1970 & 549 & 3,283 & 16.7 & 209 & 2,873 & 7.3 \\
\hline 1980 & 2,540 & 11,865 & 21.4 & 772 & 9,710 & 8.0 \\
\hline 1990 & 3,851 & 22,206 & 17.3 & 947 & 19,303 & 4.9 \\
\hline 2000 & 6,973 & 32,244 & 21.6 & 1,444 & 24,898 & 5.3 \\
\hline 2010 & 20,362 & 63,151 & 32.2 & 3,715 & 39,723 & 9.4 \\
\hline
\end{tabular}

Source: Nayyar 2013: 58 
As relative market shares of emerging and developed economies converge, global wealth and asset holdings are shifting toward emerging markets (World Bank 2011: 4). In sociological terms, however, the 'winners' of globalization remain the transnational investor class and the rising middle classes in emerging market economies whose prosperity contrasts starkly with the stagnating or falling incomes of intermediate strata in the US and EU (Milanovic 2012). ${ }^{11}$ Measured in terms of purchasing power parity, the developing world in aggregate now comprises roughly 50 per cent of global GDP, and this figure is rising as growth in Asia, Latin America and Africa continues to outstrip the US, EU and Japan. As Nayyar argues, the idea that latecomers to industrialization catch up with countries that are leaders, over time, exists in unconventional economic history and orthodox theory' (Nayyar 2012: 73). However, he cautions, this trend cannot be taken for granted, for 'there is nothing automatic about convergence, just as there is nothing automatic about growth' (ibid.). Ultimately, the process of industrialization depends on a series of structural transformations in national (and regional) economies, including most importantly the absorption of rural labour by manufacturing and the rise of the tertiary sector. Statistically the evidence suggests that developing economies now account for 40 per cent of global manufacturing, of which 88 per cent is concentrated in Asia (34 per cent of which are in high-technology industries) (ibid.: 111-13). Yet, in most emerging markets employment in the manufacturing and service sectors is haphazard and insecure, and a large proportion of workers survive due to informal labour, living in slums with few legal protections or political rights. The result is an uneven picture and, building on Amsden's (2001) typology, Nayyar lists 14 states (Argentina, Brazil, Chile, China, Egypt, India, Indonesia, Malaysia, Mexico, South Korea, Taiwan, Thailand, Turkey and South Africa) which have succeeded in approaching some level of convergence with the West. This group (the 'next 14') constitutes 73.9 per cent of the total GDP of developing nations, 75.3 per cent of developing economy manufacturing exports, and 85.6 per cent of manufacturing value added (ibid.: 129).

McAllister and Sauvant (2013: 15) assess the growing importance of FDI from emerging markets for the global economy. Data suggest that global corporations headquartered in emerging economies now account for 30 per cent of all outward and 17 per cent of inward FDI. The authors argue that the increasing importance of outward foreign investment flows by emerging market multinational enterprises are the 'latest discernible pattern' in global outward FDI: 'In a global market once dominated by the US and the EU, this duopoly gave way to the Triad of the US, EU and Japan.' However, they argue, this 'Triad declined, as Japan entered a prolonged period of economic stagnation [...] The rise in OFDI from emerging markets has contributed to the appearance of a "New Triad" consisting of the US, EU and emerging markets' (ibid.: 18). However, the concept of a New Triad - no matter how suggestive - must be disaggregated into a 'multipolar FDI world', where newer growth poles co-exist with established economies. In this sense, they concur 
with the World Bank assessment outlined above, namely that a process of global rebalancing is taking place in line with changes in the global balance of power.

To understand this multipolar global growth system, we need to consider not only statistics on the contribution of emerging market multinationals to global FDI, or their participation in mergers and acquisitions and new greenfield investment, but the wider strategies employed by emerging market economies prior to and since the financial crisis. Were it not for the catastrophic consequences of the global financial crisis for the West, it would be tempting to speculate that the decision to allow Lehman Brothers to collapse was an act of financial terrorism to facilitate the subsequent bail-out of the banking sector which in turn facilitated the leveraged buy-out of America by its financial sector (Brown 2013; Ivry 2014), sending shockwaves through the global economy, curtailing growth in emerging markets as the US struggled with the legacy of two failed military adventures, declining international goodwill and an unwinding housing bubble. However, while financial coercion is a powerful weapon - and the US financial authorities are fully aware of the negative impact of limited adjustments to US monetary policy on emerging economies - such notions are simplistic and overlook the desperate attempts by Western corporate-state elites to stem the deepening crisis in 2009 by pouring liquidity into the international monetary system.

What is clear, though - and this point is emphasized by those who remain sceptical of the long-term economic prospects of BRICS economies - is that the dramatic rise of emerging economies is determined above all not by exposure to but manipulation of globalization - that is to say, by the capacity of economies like China, India, Russia and Brazil strategically to 'shape the conditions of entry of foreign goods and companies into a country' (Beausang 2012: 13). This reflects not only the reality of negotiated adaptation to the Washington consensus (and the development of revisionist alternatives to it), but the tendency for emerging economies to rely on the state form of capital as a stakeholder in capitalist development (Ban \& Blyth 2011). From this perspective, adaptation to the Washington consensus may be more of a formality than a necessity, for what really matters is the capacity of capital operating across spatial scales to leverage commercial advantage through the oligopolistic domination of local and/or regional markets while maximizing yields from strategic FDI. Though vulnerable to monetary policy decisions in the US and other external factors, ${ }^{12}$ emerging economies are well placed to take advantage of superior economic fundamentals to attract investment and provide financial support for emerging market corporations in regional and global markets, which is changing the geoeconomic balance of power in the global capitalist sytem.

\section{New growth poles in the global economy}

While nervous investors are quick at the first sign of geopolitical risk to seek haven in US bond markets (MacDonald 2014), the ascent of emerging 
economies continues apace. Three reasons have been suggested why the crisis has had little long-term effect on emerging market growth, namely: (i) the regional form of globalization discussed in the previous section, which linked to the greater intensity and complexity of commercial and cultural ties between geographically proximate economies; (ii) the advantages of regional trade as an alternative to global market risk and the legal complexity of rules-based global trade under the purview of the Washington consensus; and (iii) the formative experience of previous financial crises in Asia, Latin America, Russia and elsewhere, which has encouraged emerging economies to develop mechanisms of regional financial integration to manage exogenous shocks. The first point we have discussed at length and it should be clear that regionalization is an essential dimension of globalization. The second point will be dealt with in Chapter 7 as a feature of counterhegemonic regionalism, which Western observers fear could undermine hopes for global economic integration and liberal internationalism by eroding the purchasing power of the US dollar and reducing Western access to resources in Eurasia. The third point, however, needs elaboration before analysing reserve currency diversification as a monetary indicator of geoeconomic multipolarity.

The impact of the financial crisis was most severe in the US due to the intensity of financialization and the failure of the US economy to recover from the collapse of the dotcom bubble economy in the late 1990s (Janszen 2010). In addition, the crisis exposed the frailty of a service economy dependent on debt-fuelled consumption as increasing numbers of Americans succumbed to bankruptcy. In the indebted consumer economies of the EU, on the other hand, crisis highlighted the lack of correspondence between monetary and fiscal policy in the absence of political unity. As Teixeira observes, the financial crisis 'revealed the limitations of a legal and regulatory strategy towards market integration which is not accompanied by the development of political integration and mutualization of economic and financial risks - ultimately a federal solution for the internal market' (Teixeira 2011: 20).

In both the US and EU, however, the crisis underlined the weakness of the financial system itself - in particular the banking sector, which had failed to meet appropriate standards of capitalization (Basel II rules) to weather the financial storm, as well as the weakness of public institutions and fiscal discipline in the southern periphery of Europe. Yet above all, the financial crisis indicated flaws in market libertarianism as states rushed to bail out the financial sector and provide subsidies for protected industries. This testified not only to the proximity/interdependence of corporate-state elites (despite neoliberal calls for non-intervention), but the political risks entailed in the sudden lurch towards neo-Keynesianism: as soon as the turbulence had eased, Western governments announced the imposition of fiscal austerity to mitigate the increased debt burden faced by states - a futile gesture in the UK where debt-to-GDP ratios are worse than Greece, where the current account deficit is the worst among OECD states, and where 'recovery' is led by a 'premature 
return to bad habits of house price inflation and credit-driven spending rather than a revival of manufacturing and productive investment' (Evans-Pritchard 2013: 1).

Developments outside the US and EU present a different picture. The crisis in the West had a severe impact on emerging market economies across the globe, but their capacity to manage and recover from the turbulence of 2008 suggests a form of 'decoupling' within global corporatism - a development some writers argue is fuelling a 'clash of capitalisms' already present after the Asian financial crisis (Breslin 2012). Not only did the crisis accelerate a preexisting shift in the balance of economic power from West to East, but the resilience and subsequent recovery of economies outside North America, Europe and Japan suggest that 'while there has been a global economic effect (and perhaps even a global economic crisis), the financial crisis was in the West' (Breslin 2012: 5). Emerging markets are increasingly employing a defensive/assertive 'shield and sword' strategy to protect their economies against contagion. This strategy has entailed two defensive measures:

First - as recommended in the 'Washington consensus' reforms promoted by the IMF and World Bank - they spent budget resources and annoyed entrenched domestic interests by introducing greater competition, honesty, transparency and stability into their domestic banking systems. Second, governments around the Pacific Rim (as well as in Brazil and India) followed developmentalist prescriptions to protect themselves by amassing an unprecedented quantity of foreign exchange reserves - thus simultaneously ignoring advice from international financial institutions.

(Armijo \& Katada 2014: 1-2)

It also entails a clear offensive strategy, allowing the BRICS in particular to leverage their new wealth by lobbying for more negotiating and voting rights in IFIs like the IMF, while offering innovative loans-for-natural-resources and tied aid to states in Latin America and Africa (Armijo \& Katada 2014; cf. Bhattacharyya 2011). This is particularly relevant in East Asia, where the traumatic experience of 1998 encouraged regional corporate-state elites to modify systems of economic and financial management to respond more effectively to turbulence by accumulating foreign exchange reserves, managing exchange rates and improving regional financial integration. For Asian leaders, the goal was to build on existing forms of sub-regional integration to consolidate the economic and financial security of the region by exploiting diversities in relative levels of economic development and capability (cf. Kumar 2004). In Latin America, on the other hand - a region scarred by the impact of coercive neoliberal reforms in the 1980s - the crisis has fuelled a shift towards neo-developmentalism. Developing ideas associated with the 'new structural economics', neo-developmentalist regimes seek to mobilize all available labour resources, transferring financial capital to high-wage and high-value-added sectors of the economy, experimenting with new 
configurations of state-market and state-society relations, while imposing new relations with international financial capital (Ban 2013; Wylde 2012).

To explain the response of East Asian economies to the crisis of neoliberalism, it is important to understand first that in a capitalist economy financial crises lead inevitably to security crises. To mitigate their impact it is necessary to create structures of regional financial governance and regulation to reduce systemic risk, for as one Japanese economist observes:

turmoil in any state's economic and financial system can undermine its very existence. Therefore, any economic crisis that cuts across national borders can be perceived by the affected countries as a 'security' crisis rather than being simply an 'economic crisis'. The economic downturn that began in 2007 and the near collapse of the global financial system certainly warrant being treated as critical threats to 'national security' for a number of countries throughout the world.

(Oba 2013: 110)

With memories of 1998 still fresh in the minds of Asian decision makers when Asian economies collapsed due to excessive short-term lending and high-risk pegs to the US dollar (Sinclair 2012a: 13) - the events of 2008 threatened renewed instability. At the same time, however, the global financial crisis offered Asian corporate-state elites a new opportunity to extend their political leverage, 'because the developed economies were in severe decline while evaluations of the potential for developing economies rose substantially' (ibid.: 110-11). Although Japan remains politically and militarily tied to the US, frustrating China's pretensions to regional hegemony, Oba concludes that the crisis of 2007-09 'altered the paradigm in the Asia-Pacific in ways that reflect a much deeper shift in global power and in the structure of the global economy' (ibid.: 111). Most importantly, however, the crisis offered Asian corporations an opportunity to test the utility and resilience of regional financial cooperation through mechanisms such as the Chiang Mai initiative (a multilateral currency swap agreement linking ten Asian states), the Asian Bond Market Initiative (a credit guarantee/investment facility linking the ASEAN+3 states - China, Japan and South Korea), and the Asian Bond Fund Initiative (ABF - a bond issue denominated in member state currencies agreed by Asian central banks to promote financial mediation and stability). In the absence of a 'grand plan' akin to European federalism, it is important to note that Asian regionalism began as a 'bottom-up' process driven largely by market forces and financial instability, but has since acquired a greater political direction as ASEAN leaders in particular identify opportunities for closer integration (Capannelli 2011).

A key reason for the establishment of intermediated bond funds in Asia is to allow regional economies with large foreign currency reserves to invest in financial assets that realize efficient returns. In a report from the 12 th 
Roundtable on Capital Market Reform in Asia in 2012, the key objective of the $\mathrm{ABF}$ is defined as developing 'efficient and liquid bond markets in the region so that savings in the region can be better utilized to the investment in the region' (Kurihara 2012). At the same time, all East Asian economies have attempted to reduce short-term borrowing from IFIs and accumulate foreign exchange reserves, while avoiding the type of investment in high-risk securities that caused financial meltdown in the US and UK in 2008.

The Asian crisis generated awareness of the need for meaningful defences against global 'hot money' - idle capital that seeks immediate returns without concern for conditionality, long-term financial commitment or managed risk. As Coppola argues, since the Western financial crisis erupted, 'there has been considerable discussion about the role of capital flows in the formation of asset bubbles and their subsequent collapse, and about strategies for managing the movements of "hot money" from country to country in search of yield and/or safety' (Coppola 2014: 1). Yet there is little consensus on whether capital controls are desirable or possible to contain or regulate 'hot money' flows of the kind that destabilized Asia. The problem, argues Coppola, is where flows of idle capital actually go when they pour into and out of local markets. Although the UK government is reluctant, despite growing perceptions of risk, to check flows of idle capital into the London property market, Asian corporate-state elites are wary, aware of the damage caused by the collapse of the Japanese property boom in 1990. To mitigate the risk to economic security, they are seeking to exploit the higher savings rate of their domestic populations to fund foreign exchange reserves to boost investment and defend investors and households against financial speculation, engineering a regional economic recovery supported by regional financial cooperation and increased exports to meet demand in China. Although these economies are keen to export to the West, the fragility of recovery in the US and Europe is stimulating the regional direction of trade and growth in Asia, albeit without reducing longstanding political rivalries (Oba 2013: 126). This is one factor in explaining the slowness of attempts to consolidate the 'noodle bowl' of overlapping trade agreements across Asia into a closer form of regional integration through the proposed Regional Comprehensive Economic Partnership under negotiation between not only the ASEAN +3 economies but also India, Australia and New Zealand (Armstrong 2013). A further stumbling bloc is China, where openness to free trade is historically less developed, where political reluctance to float the renminbi is pronounced, and where preference is shown towards bilateral partnerships rather than multilateral agreements (Volz 2010: 211).

Developments in Latin America offer a further insight into the shifting dynamics of economic regionalism in the developing world. Critics of the Washington consensus argue that the neoliberal model failed in Latin America because it 'concentrated income, reduced employment opportunities, limited business opportunities, and restricted social rights' (Wylde 2012: 17). Regional perceptions of the failure of neoliberal policies have led not to a 
rejection of capitalism in the region, however, but to qualified reassertion of developmental sovereignty in a continent where the persistence of 'heterodox economic traditions at a domestic level, the endogenous dynamics of the political system, and the extent to which corporate interests or mass publics mobilized against pro-Washington consensus technocratic elites have all contributed to bringing the state back in' (Ban \& Blyth 2011: 245). This has led to a 'proliferation of institutional and ideational hybrids' of the Washington consensus in an attempt to align globalization with 'developmental' concerns (ibid.), but has not fundamentally transformed capital accumulation regimes in a region where national-economic policy remains constrained by the power of the bond markets (Kaplan 2013).

Neoliberal scholars distinguish two main forms of 'leftism' in the region: on the one hand, sensible, 'market-friendly' developmentalism; on the other hand, 'authoritarian' left-wing populism (Castañeda 2006; Kingstone 2011). For Wylde (2012), however, this crude distinction derives from an outdated conceptual distinction between social democracy (which Latin America has never experienced) and populism that fails to capture the reality of Latin American politics. Flores-Macías (2012) offers a more sophisticated analysis of the changing character of Latin American politics, and defines the core policy goal of the Left as social justice, political demand for which has been stimulated with different levels of intensity by the fragmentation of traditionally institutionalized party systems across the region.

The shortcomings of neoliberal orthodoxy in Latin America are revealed in the growth of poverty and inequality in the 1980s and 1990s as a hindrance to economic progress. Despite the much-vaunted success of neoliberalism in Chile, between 1980 and 2008 the absolute number of people in poverty across the continent increased from 136 to 190 million, with average poverty rates falling slightly from 40 per cent to 36 per cent (Kacowicz 2013: 118-19). Poverty has, however, been declining more rapidly since the election of leftwing governments across the region due to improving educational opportunities, accelerating growth and the adoption of new policy models focused on taxation, trade, labour markets and assistance transfers (Cornia 2014).

Historically, the main causes of poverty in Latin America have been domestic (social exclusion/unequal distribution), international (dependency/ debt), and intermestic (political-institutional variables with international and domestic effects) (Kacowicz 2013: 132-3). Yet the core problem concerns the role of the state in stimulating growth: although the IMF and World Bank call for improvements in governance and institution building, there is an essential contradiction between this and the neoliberal policy prescription of 'economic conditionality', which has led to a 'retreat and weakening of the state in economic and social welfare terms, as the logical economic consequence of the insertion of Latin American economies into globalization' (ibid.: 133). In a developing capitalist economy the state should function like a 'transmission belt', guiding investment, but the narrow social basis of the state in Latin America hampers fulfilment of this role. As Kacowicz 
concludes, neoliberals wrongly assumed the 'economic problems of the region resided in the state, the solutions being in the market. As a matter of fact, the public sector of the region is roughly half the size of the industrial countries in the Western world (ibid.: 135-6; cf. Centano 2002). In fact, the precondition for growth is the reassertion of developmental sovereignty through active management of the economy rather than the depoliticization of economic policymaking. This has led Latin American governments to move beyond neoliberal orthodoxy to embrace 'inclusive growth' led by a strong state that accepts the economic logic of the market, embracing globalization as an indispensable process while pursuing a 'pro-poor pattern of growth and strong poverty-addressing policies’ (Kacowicz 2013: 136).

In practice, neo-developmentalism constitutes a pragmatic form of neoliberalism inspired by two features of postliberal capitalism in East Asia: bureaucratic autonomy, enabling the state to formulate nationaleconomic goals more independently of sectional interests; and public-private cooperation, enabling the state to form political coalitions with domestic industries (Wylde 2012: 62). Neither of these ideas is new, and neither constitutes a departure from neoliberalism. Following Rapley (2008), Wylde notes that in a global economy developmental states avoid import-substitution models to satisfy domestic demand and concentrate instead on export industries likely to promote new comparative advantages derived from dynamic efficiencies (allocative efficiencies measured over time), rather than static efficiencies (allocative efficiencies measured at a single point in time) (Wylde 2012: 66). Inclusive growth goes beyond demands for Pareto efficiency (where it is impossible to make anyone better off without making any others worse off) to recognize that not only does technical innovation entail expensive public investment in education, but that both state intervention and market exchange entail transaction costs: the question is not which is ideologically superior, but which is cost effective under given political-economic conditions. The appropriate role of the state is to lower transaction costs and it 'may even be appropriate to incur higher transaction costs through state intervention, if there were savings to be made on other costs that more than offset them' (ibid.: 68). In effect, neo-developmentalism advocates a revised form of the 'competition state' to promote growth by aligning economic goals with the investment priorities of capital markets. In this respect, neo-developmentalism is not a coherent ideology of post-neoliberalism but a partial and temporary resolution of social contradictions in the organization of capitalist power created by historical patterns of uneven economic development and backwardness in the region (cf. Saad-Filho 2010; Cerny 1997, 2000; Cerny et al. 2005; Leys 2008).

Considerations of space rule out detailed analysis of the divergent reality of 'pragmatic neoliberalism' in specific Latin American states and its sociopolitical causes. For some commentators, the rise of the left in Latin America constitutes an epochal moment, announcing the end of US 'imperialism' in the continent: 
The political result of the period of mass mobilizations [2000-03] was the emergence of 'center-left' regimes, a hybrid reflecting some of the consequences of the mass power as well as the continuities of the clientelistic politics of the past. [This period] challenged many of the fundamental features of the 'Golden Age' of US imperial rule. The movements called into question the privatizations and denationalization of the economy, the massive illicit foreign debt, the advance towards a highly prejudicial 'free trade-free market' agreement with the US and a banking system subordinated to and plundered by foreign speculators linked through overseas subsidiaries.

(Petras 2009: 452; cf. Robinson 2008)

Yet even radical intellectuals concede that opportunities for further radicalization in the region are limited, in part because of the legacy of the global financial crisis, but also because of traditional geopolitical alignments. Governments such as the Lula regime in Brazil (2003-08) exemplify the more successful features of neo-developmentalism by reducing inflation and increasing the size of the middle class (Kingstone 2011: 125), as the nation seeks recognition as a 'big country' with a surplus of soft power promoting 'consensual hegemony' in the region (Malamud 2012).

Contrary to Petras's (2008: 454) strident prediction, Brazil was in fact one of the first economies to recover after the 2008 crisis and its fiscal conservatism has won it support from investors, in stark contrast with Argentina, which is criticized for intervening in strategic industries at the expense of foreign investors. Yet at both extremes, orthodox austerity policies have been combined with pro-cyclical policies designed to relax fiscal controls and tackle poverty as governments leverage greater state capacity to channel funds into social spending. As Kaplan (2013) observes, this combination of statism and austerity reflects a desire to escape the constraints imposed by global capital markets on national policy autonomy, as well as an aversion among Latin American middle-class voters towards monetary instability gained from long and bitter experience of hyperinflation.

The key question for the present study, however, is not the political progress of the left in Latin America but the extent to which neo-developmentalism has increased financial resilience in the region as a growth pole in the global economy. The evidence suggests that while the significance of the developmental state is limited to political demands for public investment in education and greater poverty reduction, its relevance for regional financial development may be much greater. The reason for this lies in the capacity of global investors to erode the economic autonomy of governments by threatening to withdraw capital in response to higher inflation expectations, causing financial shocks with potentially devastating consequences. While Latin American states are clearly keen to move beyond IMF orthodoxy, the political fate of the region still depends on relations with the US, Europe and transnational investors. 
For Kaplan, this means that the capacity of Latin American states to stimulate their economies 'depends on their ability to develop alternative forms of financing that are less susceptible to speculative market pressures. Without such diversification, future financial turbulence threatens to intensify austerity politics' (Kaplan 2013: 284). In contrast with the US, EU and Japan, Latin American economies have sought to mitigate the threat of financial turbulence and exogenously generated shocks by vastly reducing their exposure to short-term capital flows, which are unsuited to financing long-term development goals. To insulate their economies from financial volatility, Latin American regimes have attempted to 'reduce their debt burdens, fortified their stocks of currency reserves, implemented capital controls and developed local bond markets that are less susceptible to speculative pressures from foreign investors' (ibid.). This has increased freedom of manoeuvre, leading to a reduction in sovereign risk premiums (again in contrast with advanced economies), allowing more flexibility to respond to financial shocks with counter-cyclical policies. At the same time, acquisition of foreign exchange reserves allows Latin American governments further insurance against risk and market volatility (ibid.: 286).

Although capital controls give states additional policy autonomy the political economy of Latin American capitalism is still dependent on the liberalization of financial markets. Yet the question remains whether liberalization should be achieved through international or regional financial integration, and to what extent the latter can be achieved without a parallel commitment to political or even monetary integration. As Haegen and Viñals (2003) argue, regional integration in Latin America has historically been slow for three reasons: first, because of historically low levels of regional trade integration; second, because of insufficient institutional cooperation; and third, because of frequent domestic financial crises, which have dominated domestic policy agendas in all the major economies of Mercosur, undermining attempts to widen intraregional trade ties and rationalize exchange rates. A further reason lies in the appeal of North-South cooperation with the US in preference to South-South cooperation, which has hampered trade and financial integration, a trend increased by the 'informal dollarization' of many weaker Latin American economies (ibid.: 10). Financial integration and development are thus relatively retarded in comparison with Asia and the EU, where capital markets are more advanced, and where domestic savings rates and ratios of market capitalization to GDP are much higher (Torre et al. 2007). Yet, with greater market liberalization and the return of growth after the crisis, the prospects for financial sector development in the region have radically improved, reducing regional dependence on external sources of finance while providing a 'structural shield to counteract the negative spillovers from intensified currency market volatility' (Bréard \& Blancas 2014: 3).

We can see here a parallel, albeit on a more modest scale, with developments in Asia. In both regions, regionalization is linked to the global 
ambitions of regional powers (China and Brazil), both of which are counterbalanced and constrained by the regional interests of middle-level economies (Japan/South Korea in Asia, Argentina/Mexico in Latin America). Yet economic and financial development in both regions is linked to the "hub-andspoke' dynamics of growth in the major regional economies - and in the capacity of those economies individually or collectively to promote financial depth (ratio of the value of total national financial assets to GDP) and financial resilience in the face of market turbulence caused by financial statecraft or financial mismanagement in the West. However, while global investors are keen to exploit opportunities afforded by bond markets in emerging markets, increased capital inflows are a major source of risk as investors eye cautiously changes in monetary policy at the US Federal Reserve and ECB. IMF reports attest that even where developing world states draw appropriate lessons from previous crises and pursue sound policies (i.e. policies prescribed by the IMF), they still 'remain at risk of destabilizing outflows triggered by changes elsewhere' (Atkins 2014: 1). In effect, argues Atkins, 'global capital markets have become too big for many emerging markets. When capital is pulled out by fund managers there are insufficient local buyers to step in. Turbulence inevitably ensues' (ibid.).

Although financial statecraft is a weapon typically used by powerful economies to coerce weaker states (Steil \& Litan 2006), as Armijo and Katada (2013) observe, emerging markets also employ sophisticated 'swordand-shield' tactics in preference to sovereign default or expropriation of foreign-owned assets. One answer for emerging economies is to deepen local investor bases, enabling domestic banks to buy public debt in the event of capital flight or sudden changes in monetary policy in the US. Another option is for states like the BRICS to pool capital through the creation of a self-managed contingent reserve currency fund (Wild et al. 2013), or (like China and Venezuela) to offer sovereign direct lending, providing alternative sources of finance to global capital markets. A final option is to diversify away from the dollar and conduct trade transactions in local currencies, a high-risk strategy that risks the possibility of retaliation. This is the strategy being pursued by Russia and China as the US struggles to manage the decline of the dollar. Russia in particular seeks to disengage from the US-centred global trading system and create a new locus of power centred on the EEU, a transregional organization with a wider geopolitical vision which builds on the security structures of the Shanghai Cooperation Organization (SCO) and Collective Security Treaty Organization (CSTO). Coming in the wake of bilateral energy agreements between Moscow and Beijing, this counterhegemonic geopolitical alignment constitutes a more serious threat to the transnationally constituted geopolitical strategy of the West than the posthegemonic growth poles in Southeast Asia and Latin America. 


\section{Conclusion}

The development of economic regionalism is a structural feature of and logical response to corporate globalization. On one level, governments have an incentive to join regional FTAs to limit the risks entailed in free trade and consolidate ties with neighbouring economies based on the synergies gained from proximity and propinquity. This can be seen most clearly in the EU, which is now the world's largest economic bloc, but it can also be seen in the case of ASEAN, which is developing systems of financial integration reflecting the common anxiety of signatory states towards the instability of the global financial system.

On another level, state-hegemonic regionalism reflects the aspiration of economies like Germany within the EU, the US within NAFTA, or Russia in the EEU to maximize opportunities for trade and investment based on their regional economic weight and corporate market power. For 'geoeconomic realists', this latter point is key, and demonstrates not only the importance of regional bloc formation but the tendency for military conflict to be replaced by economic rivalry. However, whether this ultimately contradicts or consolidates trends towards global multilateral trade advanced through the WTO and the US-sponsored TTIP/TPP negotiations is more difficult to predict, for the outcome depends not only on the growing power of regional competitors to the US (China, Germany, Russia, Japan, India, Indonesia, Brazil, Mexico, Iran), but on the capacity of the US to defend the institutional and ideological foundations of the Washington consensus as a condition for the survival of the dollar as a global reserve currency. In a posthegemonic global economy capital is sovereign, and it is impossible for states to resist international pressure for a return to reliable money as a means of payment and store of value for transnational trade and investment. If global trade ceases to be conducted in US dollars, this will end America's 'exorbitant privilege' and bring about a major restructuring of the international economy and a consequent realignment of world order.

\section{Notes}

1 IMF (2014: 45-67) forecasts for regional GDP growth in 2015: Japan 1.0 per cent; Europe 1.9 per cent; advanced Asia 2.2 per cent; US 2.6 per cent; Latin America 2.7 per cent; Russia/CIS 3.1 per cent; MENA 4.5 per cent; sub-Saharan Africa 5.5 per cent; developing Asia 6.8 per cent; China 7.1 per cent.

2 Bryan observes that 'households are now also conspicuous owners of financial assets, through pension schemes and home ownership. Both are now part of global financial processes, not just of high street banking' (Bryan 2012: 174). Financial markets trade in securities supported by household economies: 'This securitization sees payments out of household income forming the foundations of globally traded financial assets. The effect is that labour changes from a class in production also into a form of financial asset with a distinctive risk profile' (ibid.).

3 Prasad (2014: xiii) argues that the global financial crisis 'shattered conventional views about the level of reserves that is adequate to protect an economy from the 
spillover effects of global crises. Even countries that had a large stockpile found their reserves shrinking rapidly in a short period'.

4 On the phenomenal economic and cultural development of Asian cities, see the collected essays in Daniels et al. 2012.

5 See, for example, Nazemroaya (2012) on the expanding global influence of NATO, discussed in more detail in Chapter 7. For a comprehensive analysis of comparative regionalisms in the twenty-first century, see the collected essays in Fanta et al. 2013.

6 See the 'Manifesto against Labour' by the German-based Gruppe Krisis. The authors argue that in the 'wake of the microelectronic revolution wealth production increasingly became independent from the actual expenditure of human labour power to an extent quite recently only imaginable in science fiction. No one can seriously maintain any longer that this process can he halted or reversed' (Krisis 1999: 1). Yet, they argue, capitalism is inextricable from an ideology of abstract labour as an end in itself - that is, to create value. For this reason, 'the more it becomes obvious that the labour society is nearing its end, the more forcefully this realization is being repressed in public awareness' (ibid.). In Germany, debates on the exhaustion (Erschöpfung) of a society exposed to abstract labour as a self-destructive end in itself are advanced. See, for example, the discussion in Martynkewicz 2013. For a non-Marxist perspective on the future of labour in advanced 'postindustrial' societies, see the discussion of Beck's theory of 'second modernity' in Sørensen \& Christiansen 2012.

7 Considerations of space prohibit wider discussion of the debates in Marxism on the viability of socialist development in pre-capitalist states. While some theorists argue that socialism in a developing (peasant) economy is possible as long as capitalism is fully developed in the advanced states, as Van der Linden notes, Romein fell 'victim to a very common phenomenon among non-technically schooled intellectuals', namely, 'overestimating a people's capacity to adapt to technology - an overestimation that had led Lenin to make a "tragic mistake" (Van der Linden 2007: 157).

8 Trotsky insisted that emerging comparatively late, 'Russian industry did not repeat the development of the advanced economies, but inserted itself into this development, adapting their latest achievements to its own backwardness' (Trotsky 1932: 9, cited in Rosenberg 2013: 590). The limits of this notion were tested by the experience of Stalinism, which Trotsky criticized for its 'bureaucratic distortions'.

9 A multidimensional polarity index is a quantitative measure of an economy's contribution to the growth of the global economy, taking into account the strength of spillovers from domestic development to global growth through trade, investment and the diffusion of technology. High numbers indicate the increasing importance of a growth pole for the global economy in a given time period. For further graphic representations of this index, see charts in World Bank (2011: 15-20).

10 Commenting on Saez's paper, US News observed the growth-dampening impact of gross inequality: 'Wealthy people handle their money differently than the rest. They tend to save a much higher percentage of their incremental income, or invest it in fixed assets [...] These forms of saving and investment do not trickle down to create significant wage income for others.' On the other hand, 'incremental money that flows to the middle class and poor people gets spent much more quickly [...] Money that flows to the middle class and poor has a multiplier effect, rippling through the economy to create more jobs and income for others' (Brodwin 2013).

11 Milanovic observes that: 'In 1988 a person with a median income in China was richer than only $10 \%$ of world population. Twenty years later, a person at that same position within China's income distribution was richer than one-half the world's population. Thus, he or she leapfrogged over approximately $40 \%$ of people in the world. For India, the improvement was more modest, but still remarkable. A 
174 Towards a posthegemonic global growth system

person with a median income went from being at the 10th percentile globally to the 27 th, while a person at the same income position in Indonesia went from the 25 th to 39 th global percentile. An average person in Brazil gained, too. He or she went from being around the 40th percentile of global income distribution to about the 66th. The position of large European countries and the United States remained about the same, with median income recipients there in the $80 \mathrm{~s}$ and $90 \mathrm{~s}$ of global percentiles. But if the economic crisis that currently affects these countries persists, we should not be surprised to find the median individual in the "rich world" becoming globally poorer' (Milanovic 2012: 1).

12 One external factor worthy of mention is demand for commodities in Asia, especially China, whose relative economic slowdown has inevitable implications for relative growth rates in Latin America, Africa and other commodity-exporting regions. 


\section{Capitalist geopolitics}

\section{Introduction}

Until recently, argues Philip Stephens in the Financial Times, Western leaders believed China and Russia "would eventually decide they wanted to be like "us". China would develop as a responsible stakeholder in the existing international order and Russia, albeit with missteps, would see its future in integration with Europe' (Stephens 2014: 1). However, he adds, Xi Jinping and Vladimir Putin 'have decided otherwise. The world is waking up from [its] postmodern dreams of global governance to another era of great power competition' (ibid.). In this final chapter we will examine the merits of this observation and the extent to which it accurately reflects the unease felt by Western leaders and commentators towards the emergence of a posthegemonic order and, more specifically, the implications of Chinese and Russian foreign policy for the financial and strategic power of the West. For while Russia does indeed see its future in partnership with Europe, this is precisely what the US and UK fear the most, namely a geopolitical condominium between Berlin and Moscow which excludes the Anglosphere from Eurasia. But while relations between Russia and the West are complicated by Realpolitik, a deeper source of conflict concerns the financial logic of capitalist geopolitics, namely the social form of monetary power constituted by transnational capital in a decentred global growth system in which the US dollar now constitutes a less secure medium of exchange and store of value. The approaching conflict of the early twenty-first century is not simply a consequence of traditional great power rivalry or the refusal of the US to abandon its claim to exceptionalism, but a conflict over the right to issue and control the international unit of exchange, particularly in the global energy markets. Since 1944, this right has belonged to the US, which abandoned gold in 1971 and debased the dollar in a effort to sustain America's global financial and geopolitical power. However, America's current failure to resolve its fiscal crisis is undermining the stability of the US dollar as a transnational form of money capital, and as the global economy transitions towards a posthegemonic multipolar growth system, US corporate-state elites are faced with the prospect of a multi-currency trade settlement system and a loss of monopolistic power in the energy markets. 
The dilemma facing the Anglosphere is whether to resist this process through statecraft and war, or to engage with China, Russia and Germany to facilitate an orderly reset of the international monetary system and limit America's net loss of power in a multi-currency system. While the recent conflicts in Afghanistan, Iraq, Libya, Syria and Ukraine suggest the US is keen to block the normal development of systemic transition in international relations and maximize relative gains by using military force (or proxy forces organized by US intelligence) to create 'facts on the ground' in geopolitically catalytic states (Brzezinski 1997; Tellis 2011; Meyssan 2014), because America has more to lose from an unplanned end of the petrodollar it may eventually be necessary for corporate-state elites in the US - as the vanguard of a transnational capitalist class - to abandon the status quo and engage with revisionist states to manage the geopolitical transition to a decentred international monetary system.

It has been argued throughout the present study that capital is sovereign: if transnational investors cannot place their trust in devalued paper currencies then they will locate alternative means to secure the value of capital. As a reserve currency, the US dollar since the 1970s has provided liquidity for the international financial system and expanded its circulation by linking its value to oil - hence the centrality of oil in the determination of US foreign policy. However, the petrodollar system is now under threat - not merely from counterhegemonic powers such as Russia, but from Western allies in the Middle East whose long-term financial interests are no longer strictly convergent with the interests of the US. Western elites are acutely aware that if the present status of the dollar is unsustainable then logically it will not be sustained (Middelkoop 2014).

Expert opinion is divided, but the assumption among financial economists is that the world could shift towards a more or less stable multi-currency reserve system consisting of the dollar, the euro and the renminbi, in which gold - as an international asset that is 'nobody's liability' - is set to play a key role in cushioning global monetary reset (OMFIF 2013). Yet the same elites are also aware that the decline of dollar hegemony implies a corresponding decline of US geopolitical power, for without 'king dollar' as a means of payment, the US will have to pay its way without the 'exorbitant privilege' of unlimited credit. The real threat posed by China, Russia, Iran and Venezuela, therefore, is not that they are retreating from the dollar as a means for settling international trade, but rather that in their impatience to reform the international monetary system revisionist powers may precipitate a global reset before the US is: (i) prepared to relinquish quantitative easing as a policy tool to prevent recession; (ii) ready to adapt to a multi-currency reserve system without conceding an irrevocable loss of power; and (iii) in a position to exploit domestic shale gas production as a means to reduce dependency on foreign oil imports, and hence dependency on the petrodollar system.

To explain capitalist geopolitics, it is necessary to go beyond simplistic analyses of the military balance of power given that the US defence budget is 
equivalent to combined defence spending in the next 13 leading military powers, making any direct comparison irrelevant. The point is that the rise of emerging powers and concomitant decline of the West indicate that contemporary globalization is no longer necessarily coterminous with Western leadership - a trend reflected in the declining status of the dollar as a symbol of US global power and the decline of European ambitions to act as a normative power in world politics in favour of investment and trade strategies to leverage the financial might of European capital in its near periphery. As the unipolar order proclaimed in the 1990s fades from memory, and as emerging capitalist powers seek pluralist alternatives to a US-centric economy, the focus of international conflict is moving towards the transnational form of money capital as the material embodiment of the global power of the investor class.

As we saw in Chapter 4, to explain the changing character of world order, liberal and cosmopolitan IR theorists emphasize the emergence of a new geopolitics driven by global governance and complex interdependence. Many are critical of Western states for failing to 'practise what they preach' by not extending democracy as a political means for managing global affairs, but nevertheless believe 'consolidated democracies' in the West have a duty to lead by example and demand the internal democratization of non-Western authoritarian countries (Archibugi 2008). Cosmopolitans adhere to a normative vision of geopolitics emancipated from the lethal rivalries of the twentieth century as political power is 'tamed'. The 'new' geopolitics builds on soft power rather than force, for globalization creates 'new political spaces that are being filled in various ways by both civil society representatives and private sector actors. Such patterns of participation exert strong pressure to move the new geopolitics toward a more peaceful and less war-oriented standard operating procedures' (Falk 2012: 1). Falk concedes, however, that 'we live at a perilous historical moment. The old geopolitics is relying on hard power regardless of cost or risk, and refusing to heed experience, while the new geopolitics is struggling with torments of infancy'. It is unlikely, therefore, that the new geopolitics will triumph in the immediate future, but there is 'evidence of a sharpening tension between the two modes of sustaining security and development in the early twenty-first century' (ibid.). The 'old' geopolitics was derived from a Western-centric imperial order that is now in decline, but hard power has become less effective for achieving geopolitical outcomes through conventional warfare (cf. Kaldor 2012). On the contrary, it is suggested, asymmetric wars have exposed the disutility of overwhelming military force as a means for suppressing nationalist movements and defeating insurgencies, as the US discovered to its great cost in Iraq and Afghanistan.

This cosmopolitan vision of democratic global governance is appealing in many respects, not least for its claim that the process of democratization is always incomplete, even in the West (Archibugi 2008: 20). Despite the admirable sentiment that the principles we employ to determine rights should treat all humans as moral equals (Blake 2013), however, as a normative approach cosmopolitanism ignores the social-material determination of 
contemporary international relations in the transnational organization of corporate power - that is, the material determination of capitalist sovereignty as a transnationally constituted mode of power that intensifies global interdependence yet ultimately depends on the manipulation of outcomes through the financial statecraft and violence of state actors who rehearse the myth of equal sovereignty but implicitly reject the principles of universality and generality upon which cosmopolitanism is founded. It also dehistoricizes the transition from state-centred international relations to geocentric global governance, conflating the deterritorialization of political power in neoliberalism with a depoliticization of the international order. Cosmopolitans mistake the most recent trends in world politics (the rise of non-state actors as 'global players') for a blueprint of international relations in a multipolar world.

This universalizing projection of liberal prerogative dissolves rapidly into philosophical irrelevance when confronted by the increasingly unmanageable and chaotic reality of international politics in the present period, and reveals the failure of Western liberals to recognize that it is the contradictory agency of the US itself which constitutes the main destabilizing force in global politics, as other states wait for the US to change diplomatic course first - a fact recognized even by commentators associated with establishment policy institutions (Niblett 2010a: 4). In effect, cosmopolitans extend to capitalist globalization a directionality and functionality abstracted from the material basis of transnational corporate power as a denationalized accumulation regime $-\mathrm{a}$ new economic order aimed at the unification of peoples under plutocracy (Johnson 2014). This 'postmodern internationalism' is paradoxically fused in a complex dialectic with a geopolitical imperative determined by traditional factors such as enmity and defence of identity (Cohen-Tanugi 2008), and depends on the violence of states to negotiate and enforce the deregulation and liberalization of markets and regions necessary to facilitate the growth of corporate power and corporate-financial investment by developed and emerging capitalist economies.

Attempts to differentiate between 'old' and 'new' geopolitics fail to apprehend the material determination of international relations, embodied in the new global and regional geography of transnational corporate power. Furthermore, the cosmopolitan emphasis on a non-bellicose emancipatory geopolitics leads to a fetishization of soft power which finds its authentic origin in the social character of the commodity form in neoliberal global capitalism as an exchangeable unit of wealth produced for profitable sale rather than use value. Soft power is not a 'benign' postmodern alternative to hard power, as idealists simplistically assume; it is, rather, a policy instrument of corporate and state entities based on the perfectly logical assumption that attraction rather than repulsion is the optimal means for achieving preferred outcomes. The neoliberal mythology of 'soft power' conceals the reality of branding as a precondition for accumulation in the global economy. Contrary to popular assumptions, the exercise of non-coercive soft power to achieve voluntary compliance is contingent on more than simply network agency: 
Soft power, according to Joseph Nye, is 'the ability to get the outcomes you want without having to force people to change their behavior through threats or payments'. What complicates this premise is that a 'payment' could be made in the currency of social capital rather than in money, while a 'threat' could be made by controlling or restricting access to social capital rather than through an economic sanction. If for Nye a payment belongs to the category of hard power because it is based not on attraction and free subscription but on the issuance of cash to achieve an outcome, forms of reward and punishment implicit in networks are still left unconsidered; that is, on occasions or in situations where subscription to a standard was necessary rather than voluntary.

(Van der Velden et al. 2008: 8)

The fetishization of 'soft power' in the neoliberal imaginary is implicitly contingent on the generation of objects of desire through branding in global commodity chains that employ labour-power in the capitalist periphery yet consistently reproduce the dominant narratives of the capitalist metropole, fuelling demand for new technologies and social needs in a potentially infinite cycle of accumulation and value augmentation. Far from being at liberty to construct or project autonomous identities, unbranded ('non-polar') states occupy precarious locations within transnational networks of corporate power which determine capital allocation and resource flows in an integrated economy. As the conflict with Russia demonstrates, the corporate-strategic simulation of 'soft' power to 'attract' Ukraine involved a stage-managed combination of symbolic violence (right-populist political subjectification based on identitarian identification, emphasizing an abstract social feature that constitutes the 'people'), and naked coercion (clandestine training of neofascist militias motivated by antipathy towards Russians and Jews). The effect of this was explosive, igniting a localized proxy war in the Donetsk region while destroying Russia's attempt to assert control over its own 'brand' as an energy giant with a strategic presence in Eurasian geopolitics.

In what follows we examine two key dimensions of the unfolding conflict between Russia, China, the US and the EU over the future of the international monetary system and the long-term geostrategy of states faced with the declining power of the hegemon, building on the discussion in Chapter 5 and Chapter 6. Our first task is to examine the geopolitical dilemma of the West as it confronts the decline of a US-centric world and the increasing willingness of states to counterbalance US power. Here it is imperative to examine the self-identity and unity of the West itself which has been undermined by tensions between the US/UK and eurozone over the future trajectory of the international system and Europe's location in it. The US and EU are dominant actors (core capitalist powers) in the international system and their interrelationship is key to the construction of world order. However, while the US and EU share common interests - for example, the suppression of nationalism in the MENA region and dissemination of liberal ideology - the 
strategic priority of the EU is interregionalism (formalized relations between regional organizations), while the US favours unilateral action and bilateralism in regional contexts (weak regions held together by trade relations) (Hettne 2007: 107; cf. Reiterer 2014). ${ }^{1}$

Despite public displays of unity within the West, however, it is vital to understand the political and economic rivalry that informs US-EU relations, which are complicated by the rise of China and emerging market economies in Asia, Latin America and Africa. The spectacle of Western unity projected at G7 and NATO summits follows the protocols of diplomatic form, but this does not conceal the declining sense of common purpose within NATO. Areas of divergence within the alliance are not confined to issues of global security (e.g. disagreement over Iraq in 2003), but relate to the changing symmetries of power between the US, the EU, China and Russia, the prioritization of transnational issues (Niblett 2010b), and the rationality of intervening in conflict zones in Eurasia and the Middle East to reassert Western geostrategic and financial leadership in the face of counterhegemonic regionalism.

Gamble (2013) posits four scenarios for world order in the twenty-first century, including unipolarity (US hegemony), bipolarity (shared leadership between the US and China), multilateralism (transnational governance through the G20), and multipolar regionalism (the end of US leadership, and deglobalization). He suggests that the optimal scenario for the US is the first, while the EU is more likely to thrive in a multilateral or multipolar world without a single leading power, yet it is unclear whether the EU can manage its external relations without deferring to US leadership.

Our second task is to analyse the geopolitical strategy of the principal contender states in the new multipolar order, and the implications of Russian, Chinese and German foreign policy for Western corporate power. Limitations of space preclude an exhaustive analysis of international relations between the US and regional contender states, but it is essential to evaluate the impact of counterhegemonic regionalism as the US exports its political, fiscal and monetary crises to the international community while struggling to reassert a unilateral foreign policy in strategic conflict zones. As will be clear, there is increasing evidence that Russia and China are no longer willing to accept the terms of US international monetary policy and US leadership in international institutions. China in particular wishes to prepare its currency for a greater role in international trade and investment - not for the sake of acquiring reserve currency status itself, but as a result of dissatisfaction with the dollar system and as part of its overall plan to increase the size and wealth of China's economy (OMFIF 2013: 14). To achieve this as a 'capabilities-hiding power' (Deng Xiaoping's term), China is obliged to tread carefully between compliance with existing international institutions and preparation for global monetary reset.

Less well understood, however, are the counterhegemonic aspirations of key US 'allies', namely Germany and Saudi Arabia, whose geopolitical 
interests are no longer fully congruent with US policy in Eurasia and the MENA region. On the one hand, Germany now has the capacity and opportunity to develop as a major regional force through the expanded economic, political and monetary institutions of the EU (with or without the UK), while forging closer financial links with Russia, Ukraine and other postcommunist successor states, building on the terms of the 1994 Partnership and Cooperation Agreement and the 2003 European Neighbourhood Policy (ENP) which underpin EU trade and security ties with Eurasia and the Mediterranean periphery (Hanieh 2013: 41-43). On the other hand, Saudi Arabia (in competition with Iran) also has the capacity and opportunity acting through the GCC to counter Western influence in the Gulf and wider Middle East as the region acquires a more powerful role in global capital markets as US-Saudi relations deteriorate following the US 'tilt' towards Iran in 2013 (Chulov 2014; Viden 2014).

All four are major export economies seeking to consolidate their regional power at the expense of Anglo-American capital, inviting retaliation in the form of financial turbulence and geopolitical destabilization. The descent of Iraq into renewed conflict illustrates the dangerous consequences of shifting alliances in Mesopotamia - the 'hub' of the arc of instability in the Eurasian Balkans - as Western powers manipulate tensions in an attempt to monopolize control over the flow of energy resources, and as regional powers leverage their geopolitical influence by intervening in local conflicts.

\section{The geopolitical dilemma of the West}

If the US becomes a threat to global security, argues Smith, it will be because it finds the prospect of multipolarity intolerable: "Americans thought the "old" world they had left behind would disappear below the horizon. Instead it has turned into a global "new" world surrounding the US' (Smith 2006: 138). The geopolitical dilemma confronting the US centres on the future of Eurasia as the geographical heartland of world politics, and how to contain the geopolitical aspirations of contender states pursuing strategies beyond followership and partnership while containing escalating domestic crises in American society and rising tensions within the transatlantic alliance over its 'common purpose'.

As Mittelman (2011) argues, the global financial crisis had a lasting impact on world order, leading to a surge in securitization in Western finance and defence - a trend often unnoticed by observers who fail to link the financial and military dimensions of Western geostrategy as the US struggles to reassert its leadership in the international system and retard the formation of counterhegemonic blocs in Eurasia opposed to Anglo-American financial and military power. Although our main focus is the reset of the global monetary system and its implications for the US, this process is inseparable from the geopolitical struggle to secure the energy reserves of Eurasia, control over which is central to US geostrategy. This struggle will be determined by the 
capacity of the US acting through CENTCOM (the NATO command responsible for the area) or through regional proxies to prevent Russia and China (acting collectively or individually) from securing energy, trade and security agreements that exclude Western corporate interests, and which in turn could precipitate a decline of the petrodollar system as the strategic and material precondition for Anglo-American financial and military power. While the US and UK depict China and Russia as revisionist powers, it is the intrusion of the Anglosphere in the complex geopolitical and interethnic disputes of catalytic states in the Eurasian Balkans that is most detrimental to the achievement of regional peace and security, creating the conditions for future conflict and fuelling demands for further Western intervention.

Unravelling the complex determinants of Western foreign policy requires us to identify areas of geopolitical convergence and divergence between the US and EU, the extent to which the US and EU share a 'common purpose', and the extent to which individual states within the transatlantic alliance are willing to defect from established alliance policy and/or initiate unilateral actions in support of their own perceived corporate-strategic interests. Expert opinion on these issues is divided between Cold War liberals who celebrate the resilience and stability of the NATO alliance system in an uncertain and changing world (Brzezinski 2012; Petersen 2011; Hallams 2010), neoconservatives who mourn the lack of common purpose and complacency of the West confronted by rising powers and security threats (Kagan 2004, 2009), liberal internationalists seeking to preserve the coherence of the Western alliance (Cohen-Tanugi 2008; Thies 2009), and critical international theorists who highlight the corporate-political agendas that drive the foreign and military strategy of NATO states in Eurasia and Africa (Johnstone 2002; Nazemroaya 2012; Ganser 2005; Hoffmann 2012).

A similar lack of consensus reflects academic opinion on the interconnected issues of reserve currency diversification. For some the dollar is too firmly established as the world's premier reserve currency and symbol of US power, and is invulnerable to challenges from the euro or renminbi - particularly if European leaders fail to resolve the political and fiscal crises of the EU and Chinese leaders continue to display extreme caution over monetary policy (Williamson 2013; Prasad 2014). For others, the end of dollar hegemony is inevitable: all that remains to be determined is: (i) whether collapse is precipitated by the Federal Reserve itself (through hyperinflation), or whether an end to quantitative easing will lead to market collapse; (ii) whether pressure from global investors, ratings agencies and foreign governments will lead to a sell-off of US Treasury securities; and (iii) whether exit from the dollar will lead to a more general breakdown of the international monetary system in its entirety (Rickards 2014; Calleo 2009; Middelkoop 2014; Ivanova 2010).

Capitalist geopolitics and monetary power are irrevocably intertwined, and each move made on the 'grand chessboard' reflects the deeper struggle by capital to achieve security in an increasingly decentred global economy. However, while foreign policy is driven by geostrategy, it is also essential to 
consider the impact of domestic-political factors in capitalist geopolitics, for while militarism entails risks, the prospect of open-ended, low-intensity military engagement in Eurasia provides a pretext for silencing political dissent, absorbing excess capacity, offsetting deflationary pressures in the economy and stabilizing the power of dominant capital in the financial markets. Viewed historically, geopolitical instability tends to increase at the peak of capitalist power - as in the 1940s when (as now) the income share of the top 10 per cent of American society approached 50 per cent of GDP. As the plutocratic power of wealthy elites approached this level, there was little room left for further enrichment of capitalist elites, who subsequently suffered a relative loss of power under the New Deal (Nitzan \& Bichler 2012: 42). Put differently, systemic crisis and geopolitical instability coincide at a point where capitalist power approaches its asymptotic limits, after which logically it can only be sustained through increased violence until all wealth is appropriated by financial elites. In the transition from democracy to oligarchy, the US and UK are characterized by levels of inequality not witnessed since the 1930s, accelerating the impoverishment and proletarianization of the middle class and the fracture of meritocracy (Piketty 2014).

As is apparent in Greece, where unemployment reached 27 per cent of the working population in January 2013 (Papageorgiou 2013), a rapid deterioration of economic conditions cannot occur without major political consequences, for the closer capitalist power approaches its limits, the more resistance it creates: 'the greater the resistance, the more difficult it is for those who hold power to increase it further; the more difficult it is to increase power, the greater the need for even more force and sabotage' (Nitzan \& Bichler 2012: 21). This sabotage assumes many forms, including recession/unemployment and increased police repression; or governments can temporarily sustain the illusion of prosperity by transferring negative inflationary effects of excess liquidity to developing economies. Alternatively, for militarily powerful states like the US, economic crisis can be used to justify organized violence and war. As Schmitt (1932) argued, violence is a constitutive dimension of modernity rather than its prehistory (cf. Malešević 2010), and perhaps the most dangerous consequence of systemic fear among capitalist elites is that it will lead to an intensification of politics: a catalyzing moment leading to a suspension of rule of law and externalization of conflict through military adventurism justified in the language of statecraft or liberal universalism.

How, therefore, should we explain the geopolitical strategy of the West confronted by the prospect of declining economic power? The first and most important point is to demonstrate the limits of older geopolitical theories based on geographical determinism. A key thinker in this tradition is Mackinder, whose seminal paper 'The Geographical Pivot of History' (1904), influenced a generation of strategists in Britain and Germany, as well as Russia and the US. Mackinder's Heartland thesis is an early illustration of sweeping grand theory in the classical realist tradition which must be placed in the context of its time. For Mackinder, 'all political action occurs in a 
geographical context, and spatial relationships, keyed to the facts of relative location, are almost invariably of significance. In other words, political behaviour necessarily is geopolitical' (Gray 2005: 27). The academic study of geopolitics suffers from 'guilt by association' because it has been appropriated by imperial geostrategists (Mahan, Haushofer, Spykman, Brzezinski, etc.) since its inception, but for Gray this makes as little sense as condemning medical research for its obsession with disease: 'Because much of academe hold to the liberal illusion that international relations can be transformed benignly', he observes, 'it associates geopolitics and its generally realist approach to statecraft, with conditions that need to be changed' (ibid.: 28).

The authentic ethical question is the motivation for seeking geopolitical knowledge in the first place and the practical use made of it by strategists acting either as cheerleaders for their respective governments (Ahrari 2011; Brzezinski 2012; Mahnken 2012), or as objective researchers. Insights obtained through the study of statecraft are morally questionable if and only if they are used to justify or facilitate coercive diplomacy and war, not if they are intended to theorize the actions of bellicose states that regularly engage in coercive diplomacy and war. The real weakness of traditional geopolitics is its lack of reflexivity and failure to calibrate its classical realist premises through dialogue with other critical traditions. As noted in Chapter 2, however, this theoretical limitation can be overcome once we abandon geographical determinism and acknowledge that behind geopolitical actions and concerns economic interests are generally present (Adamo 2001).

To illustrate this point it will be instructive to examine briefly the uncritical and unreflexive thinking of Western geopolitical theorists who continue to call for assertive US leadership yet fail to consider the implications of global economic convergence for the future of the West. From a geopolitical perspective, the US is the intrusive force in Eurasia - a 'non-resident dominant military power' (Ehteshami 2007) - for it is assumed that unless the US continues to try to influence the outcome of diplomacy and conflicts over energy in Eurasia, it will decline into geopolitical irrelevance - becoming the 'EU of the Western hemisphere' (Walton 2007). In other words, the US cannot simply allow regional developments to take their course because this would undermine the agency of Western financial capital in Europe and Asia.

Students of geopolitics are in this respect deeply influenced by the work of Mackinder (1904), whose anxieties towards Russia as a potentially impregnable Eurasian land power still resonate in the work of strategists who see it is as imperative for the US that 'no power or coalition attains hegemony in eastern Eurasia, much less that an explicitly hostile state or coalition succeeds in doing so' (ibid.: 65). Although the US sustained its global power in the post-war period by containing the Soviet Union and preventing Eurasian powers from exerting influence over the Western European and South-East Asian peripheral zones (a policy advocated by Spykman (1942) in his analysis of the 'Rimland'), Western strategists today continue to argue that unless the US maintains a military presence in Eurasia and controls the pace of China's 
internal balancing and economic modernization, the region will once again become closed to Western influence. This, they insist, would deny Western energy firms access to the rich oil and gas deposits of the Caucasus and Central Asia, a transregional space that will eventually be integrated into a Eurasian trade and security system led by China and Russia as the key BRICS economies and principal signatories to the SCO (see below).

While Walton acknowledges that the US must 'adapt its foreign policy to emerging realities' and abandon the illusion of unipolarity at the risk of marginalizing itself among allies (Walton 2007: 9), other theorists advocate a renovated 'twenty-first-century geopolitical strategy' to consolidate Western power through an ideological and strategic 'projection of the West' into Eurasia justified in accordance with Toynbee's universalizing conceptualization of the West as the 'practical application of ideas based on reason and humanism in response to Asiatic authoritarianism' (Petersen 2011: 8). If Western policy elites fail to evaluate the future geopolitically, argues Petersen - that is, to understand the development of international relations in the present epoch in terms of the geopolitical logic of Mackinder's World Island theory, then the 'pre-eminence and power of the West will diminish far more rapidly than many might expect' (ibid.: 9).

While this claim is not entirely false - historically the West has not hesitated to use military power to advance its financial and geopolitical goals in Eurasia - to suggest that Western economies cannot expect to prosper without a proactive policy of regional intervention is dubious. Petersen claims that if the global economy is to prosper 'as prescribed by the Smith-Ricardo free trade model, then the West must be grown into Eurasia and its values and institutions transplanted there' (Petersen 2011: 103), yet simultaneously calls for a proactive interventionist strategy to ensure that Eurasian economies do not develop bilateral trade and investment ties that disfavour Western corporate interests. Though the hypocrisy of this argument is breathtaking, the real issue here is the practical distinction between a 'liberal globalist' strategy defined with respect to international-legal norms and multilateral engagement, and a 'neoconservative' strategy freed from the juridical constraints of international law.

For some, this highlights the quintessential difference between European and American approaches to international relations, reflecting the normative commitment of EU states to legality and multilateralism and the unilateral commitment of the Anglosphere to transnational financial interests. For others, however, it is a false distinction, not merely between the EU as an 'enlightened force' and the US as an imperial power, but between liberalism and neoconservatism - ideological distinctions that collapse into irrelevance if or when the transnationally constituted geopolitical interests of the core capitalist economies are compromised. To illustrate this point we need to examine the geopolitical dilemma of the West with reference to the internal cleavages and conflicts between leading fractions of capital within the Lockean heartland, before widening our investigation to explain how the increasing 
tendency of regional powers in Europe and Asia to check the power of AngloAmerican capital through strategic engagement and political commitment is accelerating the transition to de facto multipolarity.

Smith (2014) argues that while the US is 'selectively' multilateralist and China is 'experimentally' multilateralist, the EU is by default and of necessity a multilateralist regional bloc which despite its internal divisions over foreign policy tries to advocate a consensual approach to diplomacy. This is of course an ideal-typical simplification, for between the EU, US and China there is 'a mosaic of multilateral, quasi-multilateral and bilateral relationships that reflect the different approaches and experiences of the parties and which give rise to the often uneasy relationships among the fragments of order to which they give rise' (Smith 2014: 11-12). While it is possible to measure the nature of multilateral agency pursued by the three economic blocs by examining forms of strategic engagement, political commitment and diplomatic interaction, these too are ideal-typical caricatures of agency deployed to achieve outcomes under variable conditions.

To understand the complex transnationally constituted geopolitical agency of the West, it is essential to abandon the faulty differentiation between conventional and normative power resources deployed by capitalist economies in the transatlantic alliance to achieve their individual or collective goals. This distinction gained traction as a result of the diplomatic row between the US/ UK and the Franco-German entente over Iraq in 2003 - a dispute in which Germany 'arguably prevented NATO from taking the role of compliant alliance partner and doing what the United States wanted' (Schmidt 2008: 57). This dispute was instrumental in emancipating Germany from slavish adherence to American foreign policy (weakening support for the Euro-Atlantic orientation of the EU), but has less to do with pacifist multilateralism than perceptions within the Franco-German axis of their mutual geopolitical interests as the force behind 'deep' integration and the expansion of European capital into Western Eurasia and MENA in conflict/cooperation with the Anglosphere (Nazemroaya 2007).

As Therborn argues, the EU faces three possible futures. The first is to become the 'new West Germany', a powerful and competitive regional economic bloc based on the power of German industrial and financial capital and the willingness of the German taxpayer to compensate for the poorer economies of the southern eurozone. The second is to revert to being America's 'attack dog', 'helping to drive the prey into the guns of the Americans, and taking care of the prey killed' (Therborn 2007: 293). After the Iraq fiasco this scenario was ruled out by most commentators, yet the eastward enlargement of the EU and the eurozone debt crisis have made it easier for the US and UK to undermine the collective rationality of 'Old Europe' within the EU and to relegitimize America's leadership of NATO based on historic fears of Russia. ${ }^{2}$ A final option is to promote the EU as a model of economic efficiency, social security and environmentalism, which could establish the Union as a kind of 'global Scandinavia', a normative force in world politics. 
The strategy favoured by German capital is the first, but as the crisis in Ukraine illustrates, Europe remains a geopolitical platform for American sea power and the EU may be driven against its will towards conflict as the US tries to force European elites to choose between East and West in an attempt to prevent the forging of closer trade and security ties between the EU, Russia and China that might undermine US influence in Eurasia via its bridgehead in the NATO accession states of Eastern Europe. ${ }^{3}$ Integrating Ukraine into NATO after the 'Orange Revolution' of 2004-05 would have been a logical extension of this policy for the US and the EU, weakening Russia's geopolitical position in Eurasia and extending the economic space of the ENP. As we shall see, however, after the brief but decisive conflict in Georgia in 2008, this policy was blocked by the CDU-SPD coalition in Germany which sought to extend diplomatic engagement and security ties with Russia through the Partnership for Peace (PFP) and mutual acceptance of the terms of the 1997 Founding $\mathrm{Act}^{4}$ as the optimal means for reducing tensions in Europe's eastern periphery - although Russia has always viewed the PFP purely as an international framework for security cooperation rather than defence integration in order to guarantee its strategic autonomy (Simon 2008).

The political crisis in Ukraine presents EU states with an historic opportunity to develop transnational leadership in the transition to a multipolar global order, building on their experience of dealing with non-traditional security threats and promoting trust and confidence building in other political contexts (Reiterer 2014). Yet in practice the conditions for achieving collective rationality in international relations are difficult to sustain where individual actors do not have full control over their acts - that is to say, where acts are not options but the consequences of variables beyond the control of the agents in question. This is not because collective rationality is impossible to achieve but because rationality is feasible if and only if it is the product of acts that its members fully and freely control (Weirich 2010). In the EU these preconditions do not apply, for just as global corporate interests take precedence over the national-democratic interests of the US, there is reluctance among European governments to embrace the geopolitical implications of posthegemonic regionalism because the costs of soft balancing against the US/ $\mathrm{UK}$ and the political constraints on collective rational decision making are high. Rationality is a normative ideal, the achievement of which implies that acts are justified and warranted within the constraints of imperfect information. The geopolitical agency of the US/UK is precisely the antithesis of this, namely, unjustified and unwarranted, oriented towards the creation of unpredictability and risk through covert intervention in geopolitically catalytic states. $^{5}$ As the crisis in Ukraine has demonstrated, the transnationally constituted geopolitical agency of the Anglosphere undermined the capacity of the EU to act rationally as a emerging regional entity:

With 28 members of diverse language, culture, history and mentality, the $\mathrm{EU}$ is unable to agree on any foreign policy other than the one 
Washington imposes. The extension of the EU to former eastern European satellites has totally broken whatever deep consensus might have been possible among the countries of the original EEC: France, Germany, Italy and the Benelux states. Poland and the Baltic States see EU membership as useful, but their hearts are in America - where many of their most influential leaders have been educated and trained. Washington is able to exploit the anti-communist, anti-Russian and even pro-Nazi nostalgia of north-eastern Europe [...] to obstruct the growing economic partnership between the old EU, notably Germany, and Russia [...] Apparently abandoning Europe's accumulated wisdom, drawn from its wars and tragedies, and even oblivious to their own best interests, today's European leaders seem ready to follow their American protectors to another D-Day.

(Johnstone 2014: 2)

The EU is an integral component of the Lockean heartland, and EU leaders are aware that the purpose of CENTCOM is to block a transition in the international system and enforce a division of the Eurasian landmass to perpetuate US hegemony, which obliges corporate-state elites in the eurozone to compromise specific EU interests for the sake of transatlantic relations. Europe does not follow the US blindly or stupidly, argues Lagadec (2012: 18, emphasis in original), 'but because contrary to America itself, Europe cannot comfortably live in a post-American world'. A similar point is suggested by Baun (2014), who argues that it is precisely because of the opportunities and risks posed by a changing world order that a new transatlantic 'partnership' must endure, for even as the EU consolidates trade and investment links with Russia, China and the MENA region, the diplomatic and security incentives for bandwagoning behind the US are still too powerful to resist in European capitals. Confronted by instability in geopolitically catalytic states such as Ukraine or Georgia, EU leaders are far too divided and pusillanimous to resist US leadership, and are therefore unable to prevent the US from turning political crises into an artificial choice between contradictory outcomes: on the one hand, consolidation of trade and security ties between the EU and Eurasia independent of US influence; on the other hand, the extension of NATO into Eurasia (and therefore into Russia's sphere of influence).

This, of course, is exactly what Brzezinksi (1997: 40) advocated in his geostrategic policy prescription, namely that the US should 'prevent collusion and maintain security dependence among the vassals, to keep tributaries pliant and protected, and to keep the barbarians from coming together'. In the conflict over Ukraine it has been useful for the Anglosphere to revisit the rhetoric of the Cold War to undermine Russia's attempt to take control over its own sovereign brand in the quest to acquire 'soft power', though it is not Russia which seeks to rebuild the 'Iron Curtain' but the Anglosphere, creating a cordon sanitaire between Germany and Russia to limit integration between Germany and the BRICS, which - while a concern for the US, would enable 
Germany to consolidate its capital base and industrial-technological power in Eurasia while pursuing policy goals laid out in the 'BRICS+G' Sustainability and Growth agenda (Escobar 2015; cf. Bachmann 2005).

To conclude, it might be argued that the real dilemma facing the West concerns the tension between multilateralism and regionalism in the search for Western economic and political security. Korybko (2014) suggests that the Anglosphere is actively involved in frustrating major regional infrastructure projects on a global level, using 'segmented and patterned' strategies to weaken 'resistant and defiant cores' in Eastern Europe, the Middle East, East and South-East Asia, and Latin America - the targets of which are, respectively, Russia's Eurasian Union, the Iran/Syria/Lebanon condominium, China, and Brazil/Venezuela. There is little question that the US and UK clearly favour a more aggressive approach to the Eurasian question, while Germany is more cautious and reluctant to alienate Russia, in part for fear of undermining the energy agreements that constitute a major component of Russo-German relations. Although the US worked to ensure NAFTA would become a regional/hemispheric FTA in which American corporate interests would predominate, and seeks to extend the terms of NAFTA to transatlantic trade with the EU through the TTIP, the US sees no value in regionalism in itself (and, it should be added, sees little intrinsic value in multilateralism unless it yields relative gains). Whereas the US has an interest in preventing the consolidation of strong regionalism as an alternative to (i) the 'Washington consensus', and (ii) the transatlantic security alliance, however, the EU is in favour of post-Westphalian interregional engagement and trade, although EU policy has so far failed to develop in a coherent or systematic way with regard to Asia, Africa, Latin America and MENA (Hettne 2007). There is a temptation prima facie, therefore, to believe the EU represents a civil alternative to hard power, where interstate coercion is replaced by co-governance based on the assumption that 'what has worked in Europe may ultimately prove to have wider relevance [for world order]' (ibid.: 121). This point is made by Simoni (2013), who from a constructivist perspective looks beyond shared security interests, economic interests and cultural values to argue that a de facto division of labour exists between the two sides of the transatlantic alliance, where the US acts as military power of last resort, while the EU is concerned with definitions of international justice. Yet this is also too simplistic, for it ignores not only the divergence of interests between EU member states that typically fail to reach consensus on external policy, but the capacity of the US to limit European autonomy and retard systemic interregionalism in favour of market-led globalization under Anglo-American leadership. ${ }^{6}$

\section{Counterhegemonic regionalism}

In December 2010 Paul Volcker argued that with US power in decline, the 'growing question is whether the exceptional role of the dollar can be maintained' (quoted in Lenzner 2010). The former chairman of the Federal 
Reserve followed up this missive by articulating grave doubts about the coherence of the world economy, observing that it is 'hard to call what's going on a financial system [...] Where can the leadership of the global financial system come from?' (ibid., emphasis added).

For many observers, the answer is China, as the largest creditor and the most powerful emerging economy, yet few economists would argue that China is willing or able to assume a hegemonic role in the international financial system in the near future. In developmental terms, China is a post-revolutionary society whose leadership emphasizes the importance of 'reality and usefulness' in the construction of social order, working in a Comtean sense towards the 'reorganization of human life in practical and scientific terms' (Liu 2012: 61). Although Arrighi believes that the 'social outcome of China's titanic modernization remains indeterminate' (Arrighi 2007: 24), the cultural-political reality of Chinese capitalism is the complete implosion of totalizing collectivism and its replacement by the 'irresistible force of narcissism' driven by material desire and egocentricity (Liu 2012). Eschewing its revolutionary past, China does not seek a return to the chaos of Maoism, only a return to genuine multipolarity (Pan \& Chen 2012). ${ }^{7}$ Not only does China wish to avoid antagonizing the West, but it is aware of the tensions in Sino-US relations that could undermine its comprehensive national strategy ("peaceful rise and development') of adapting to global capitalism and increasing its material wealth and prestige as the pre-eminent economy in Asia without alarming its neighbours.

Yet misunderstanding of China is at heart of the strategic dilemma of the West, whose elites either misconstrue China as a geopolitical 'threat', or denounce the rise of Chinese nationalism, failing to notice that not only must China achieve modernization and internationalization at the same time (Yiwei 2012), but that imposing artificial constraints on China's growth and development is to impose constraints on the sovereignty of capital, thereby artificially restricting the future development of globalization in its transnational and regional forms. As we have seen, the opening of Eurasia to capital instantiated by globalization has problematized the international political economy of Western power. As an historically insular civilization-state, China is less of a security threat to the West than a powerful expression of the emancipation of capital from its Lockean heartland to the 'interstices' of the global economy (Westra 2010). This global economy incorporates diverse economic regions into decentred networks of country clusters and commodity chains, and is decoupled from territorial sovereignty. The economic modernization of China is not just a result of 'capitalism with Chinese characteristics', as Huang (2008) argues, but the pre-eminent example of capitalism in its postliberal corporate form, as a result of which Chinese capital is poised to exert increasing global power in partnership with developed and emerging market economies, in contrast with the violence imposed by European trading empires on economically 'static' regions of Africa and Asia. Though criticized for its voracious pursuit of commodities in exchange for development 
cooperation, China now plays a major role in the modernization of resourcedependent nations in the global South, and 40 African countries have signed trade agreements with Beijing allowing price-sensitive economies access to low-cost Chinese consumer goods (Bhattacharyya 2011: 101; cf. Marton \& Matura 2012; Carmody 2013).

The Western dilemma over China is articulated in the tension between a policy of containment versus accommodation - the former based on strategic engagement and alliance formation in the Asia-Pacific region, the latter based on the integration of China into the global economy. This dilemma pits neoconservatives against pragmatic realists, and both against 'naïve' globalists. One of the main reasons for the incoherence of American economic and strategic policy towards China in the Bush-Cheney period stems from the contradiction between the Republicans' loyalty to corporate interests and reluctance to alienate lower-middle-class 'backlash conservatives' as the White House struggled to 'accommodate the inclination of US capital to profit from the Chinese economic expansion, and simultaneously pander to the national-militarist dispositions of its electoral base' (Arrighi 2007: 306). Yet the fundamental issue for the West is not how to balance China's military modernization (by supporting Japanese, Taiwanese and or Indian regional aspirations as counterweights to Chinese domination in Asia), but how to resist China's determination to challenge the dysfunctional position of the dollar in the international monetary system. Unlike China's military modernization - which has been conducted with maximum secrecy to deflect attention from its application of dual-use technology imports to transform its military capability and increase hard-power projection (Fisher 2008) - China is open in its desire for monetary reset, calling for an orderly transition to a multi-currency system where the dollar is traded alongside other currencies (and gold) as a diversified asset for reserve holders (OMFIF 2013).

For China the instrumental goal is to widen the use of the renminbi as a globally traded currency to increase China's economic power; but while China is prepared to cooperate with Western IFIs (and contributed to stabilization of the global financial system in 2009 in return for representation in Western-led global institutions), its geoeconomic strategy is based on the multilateral logic that 'saving' the West is simultaneously to save Chinese economic modernization itself (cf. Vangeli 2013). China is keen to cooperate with the West where this yields positive-sum results, but is proudly resistant to US demands to reform its political system and is willing to use multilateral engagement, soft balancing and military modernization to erode US leadership (Ahrari 2011). Indeed, despite their characteristic cautiousness, China's leaders have in some instances failed to conceal their exasperation towards the conduct of US fiscal and monetary policy, as revealed in an undiplomatic statement released in October 2013 following the shutdown of the US Federal government, when the Chinese state news agency announced that 'such alarming days when the destinies of others are in the hands of a hypocritical nation have to be terminated' (Xinhua, in Pento 2013b). 
China is also showing greater willingness to exploit bilateral and multilateral ties with Eurasian states to realize its aims, particularly through the SCO, and China's deepening ties with the EU, Latin America, Africa and MENA are a cause for concern for Western elites anxious to limit the rate at which China's economic footprint expands in coming decades. At stake for China is the need for a stable international environment to support the modernization and internationalization of its economy which leads China to avoid open hostilities. As Saunders argues, China needs 'positive relationships with current and potential great powers to facilitate the emergence of a multipolar world order and to deny the United States the opportunity to construct a coalition to contain China and prevent its continued rise' (Saunders 2008: 128). At stake for the US, on the other hand, is not simply the growth of power centres resistant to Western leadership, but the prospect of a premature or involuntary loss of geopolitical control over the global commodity form of fiat money as the primary means of payment in a global economy where trade/investment ties with China are acquiring greater appeal for emerging economies than dependence on the Anglo-American system of debt-based finance.

This explains the significance of the deal between China and Russia completed in November 2014, which signalled a transformation in Eurasian geopolitics with implications for the petrodollar system. Although the scale of the deal (\$400 billion) is significant in itself, turning China into Russia's second largest customer after Germany while ensuring Gazprom an Asian market for 25 years, for many Western commentators its geopolitical significance lies in the fact that bilateral trade deals of this type threaten the monetary foundations of Western hegemony:

If Russia's 'pivot to Asia' results in Moscow and Beijing trading oil between them in a currency other than the dollar, that will represent a major change in how the global economy operates and a marked loss of power for the US and its allies. With the dollar as the world's petrocurrency, it also remains the reserve currency of choice for central banks globally. As such, the US is currently able to borrow with 'exorbitant privilege' [...] simply printing money to pay off foreign creditors. With China now the world's biggest oil importer and the US increasingly stressing domestic production, the days of dollar-priced energy, and therefore dollar-dominance, look numbered. Beijing has recently struck numerous agreements with major trading partners such as Brazil that bypass the dollar. Moscow and Beijing have also set up ruble-yuan swap facilities that push the greenback out of the picture.

(Halligan 2014: 1)

The implications are clear: if global rebalancing continues on its present trajectory and emerging economies abandon energy pricing in dollars, the dollar's reserve currency status 'could unravel fast, seriously undermining the US 
Treasury market and causing a world of pain for the West' (Halligan 2014: 1). For China and Russia, however, the deal is a further step towards exiting the petrodollar system and establishing greater independence from the AngloAmerican transnational capitalist class, although the petrodollar will survive until Saudi Arabia itself decides to seek alternatives to US patronage. As the collapse in the oil price in 2014 indicates, Saudi Arabia is the key petroleum exporting power that can use its spare capacity to undermine the financial viability of other oil-producing powers and influence geopolitical developments in America's favour - albeit at the price of undermining the profitability of US shale gas production. A similar interpretation can be applied to the announcement in July 2014 of the formation of a \$100 billion BRICS development bank to be headquartered in Shanghai, which some Western commentators were quick to dismiss as of 'symbolic geopolitical importance'. The BRICS bank's real purpose, argues one journalist at the Financial Times, 'is to act as a competitor to the US and European-led institutions [...] and to demonstrate that the BRICS nations are not hostage to these constructions of a previous world order or indeed to anything run by the major western powers' (Leahy 2014: 1).

Yet the announcement comes after two years of negotiation between the BRICS partners whose demand for more voting rights in Western-led IFIs has been thwarted by US intransigence, and whose aim is to reduce dependence on the Western-led financial system and shield their emerging economies from the financial turbulence emanating from the US as the Federal Reserve vacillates over whether and how to scale down ('taper') quantitative easing without triggering a collapse in equity markets - as witnessed in October 2014 when even a mild tightening of monetary policy in the US led to market falls (Evans-Pritchard 2014b, 2014c). It also coincides with the launch of the BRICS(A) currency as a medium of conducting non-dollar denominated trade, the new AIIB as a rival to the World Bank in Asia, and a new international payment settlement system to rival SWIFT (Koenig 2014). However, while some commentators insist this 'economic sea change may bring the empire to its knees, without spilling a drop of blood' (ibid.), as evolving ties between emerging markets erode the power of the West over international finance, history suggests that geopolitical transitions of this order of magnitude do not occur in a benign or orderly fashion. On the contrary, there are reasons to expect that monetary reset will lead to currency warfare, political warfare and economic espionage, the consequences of which are unpredictable. ${ }^{8}$ While an abrupt collapse of the dollar would be catastrophic for holders of US debt, the US has more to lose through reset although 'loss' is defined by Western media in terms of global financial instability rather than a decline of Western power (Boyes 2014).

From a Western neoliberal perspective, China and Russia seek to dominate the Eurasian landmass and exclude the West from open access to their energy resources and mineral wealth, yet relations between these two Eurasian powers are more complex than this allows, and Sino-Russian cooperation 
cannot be understood without reference to third-party relations with the US (triangulation), the EU, Central Asia, India and the Middle East. Diplomatic and commercial relations between sovereign territorial units or economic blocs are typically based on strategizing behaviour - that is, where decisions are taken on the basis of available information to engage with or reject opportunities for cooperation, competition and counterbalancing with allies and rivals. Of course, such 'rational' agency is determined closely by the perspectives of individual or collective agents for the 'decision to participate in a multilateral organization is not inherently a rational or predictable reaction to an objective set of interests' (Aris 2011: 11). On the contrary, argues Aris, 'an actor's behaviour is only explainable within the specific context of its perceptions at any given moment in time, and these perceptions cannot be predetermined' (ibid.).

From this perspective, the historical context of rational decision making can only be used to make weak predictions of future behaviour, for international relations lack permanence and priorities and loyalties change rapidly. In reference to the example above, it is clear that China's paramount concern is energy security - to ensure uninterrupted growth - which is in turn dependent on supply, price stability and security of delivery (Ahrari 2011; cf. Marketos 2009). Russia's paramount concern, on the other hand, is to leverage the more restricted geoeconomic power of Russian corporations in a changing multipolar environment by making optimal use of its key strategic resources (energy/defence). Up to 2003-04, Russia was pliant in its dealings with the US, which caused some concern in China, but as the balance of power shifted in the wake of Iraq and Moscow sensed a failure to gain tangible benefits from its alignment with the West, Vladimir Putin tilted Russian foreign policy back towards China to counterbalance the growing US military presence in Central Asia (Swanström 2012; Stent 2014). Russia's strategic position is outlined in its 2009 'National Security Strategy':

World development is following the path of globalization in all spheres of international life, which in turn is characterised by a high degree of dynamism and interdependence of events [...] Values and models of development have become the subject of global competition. The vulnerability of all members of the international community to new threats and challenges has grown. As a result of the rise of new centres of economic growth and political influence, a qualitatively new geopolitical situation is unfolding. There is an increasing tendency to seek resolutions to existing problems and regulate crisis situations on a regional basis, without the participation of non-regional powers. The inadequacy of the current global and regional architecture, oriented (particularly in the Euro-Atlantic region) towards NATO, and likewise the imperfect nature of legal instruments.

(National Security Strategy of the Russian Federation to 2020: para. 8, emphasis added) 
Although Moscow is wary of becoming too dependent on China's demand for energy, Russia needs China to offset resistance within the EU towards energy dependence on its eastern neighbour, and - despite Russian fears of Chinese mass immigration - requires Chinese investment to develop Siberia and the far east. Russia must also compete for Chinese commercial ties with rival energy exporters in Eurasia, including Azerbaijan, Iran, Turkmenistan and Kazakhstan, and although it does not wish to be reduced to the role of a subordinate provider of resources, it is unwilling to cooperate too closely with the West for fear of alienating China and thus losing the opportunity to make strategic gains through mutual Sino-Russian engagement with the US. For this reason Russia is willing to cooperate with China in the SCO, an Asian regional structure that excludes the West and unnerves Western policy elites whose capacity to influence the direction of Russian foreign policy has declined since the collapse of the 'Obama reset', and more recently following US actions in Ukraine which have undermined Russia's incentives to cooperate with the West to contain China's rise in Asia.

What, therefore, are the prospects for counterhegemonic regionalism in Eurasia and what are its potential implications for the West? Western critics claim that not only is the SCO a dysfunctional regional organization which issues frequent and grandiose declarations on trade and security while failing to make significant policy decisions, but that Sino-Russian bilateral cooperation is driven by negative integrating factors, mainly the 'problematic relations they have with the outside world' (Swanström 2012: 11). Again, however, this is hardly a straightforward question and Western assumptions of China's irresistible rise and Russia's corresponding decline cannot fully explicate the dual logic of cooperation and rivalry between the two Eurasian powers in their dealings with the US and EU or their competing perceptions of security and development in Central and East Asia.

The most important point, as Laruelle correctly observes, is that the 'SinoRussian entente is based on a mutual rejection of the so-called unipolar world under American domination, not on any substantive agreement' (Laruelle 2012: 87). Historically, culturally and geopolitically there is no natural harmony of interests between China and Russia that could not be disrupted by the emergence of (potentially unforeseeable) alternative geopolitical alignments: China is an Asian power that seeks to dominate East Asia in the future - an area where Russia is no longer able to project power without great effort; Russia, on the other hand - despite its occupancy of the northern Eurasian landmass - is still primarily a European entity with an historical legacy of influence in Central Asia. There is no question China is the dominant force in the entente, yet Russia continues to enjoy strategic preponderance in the geostrategic heartland of Central Asia, particularly since the announcement of the withdrawal of US forces from Afghanistan and the closure of the last US airbase in Kyrgyzstan (Dzyubenko 2014). While it is the stronger economy, China is willing to tolerate Russian military preponderance in this closed region in preference to US military encirclement of its western borders, 
for even though the CSTO excludes China, it relieves Beijing of responsibility for organizing regional security (ibid.: 81). Although the two states are competitors in Central Asia (Laruelle \& Peyrouse 2013), both cooperate with the authoritarian secular regimes of the region to combat political Islamism and reduce the risk of 'colour revolutions' of the type that occurred in Kyrgyzstan in 2005. In addition, through the SCO, China and Russia coordinate collective action against terrorism, extremism and separatism - the so-called 'three evils' that contribute to regional insecurity. In these respects, at least, although bilateral relations are cordial rather than warm, there is clear recognition of mutual interests, which is not entirely negative.

The US does not fear the CSTO as a serious rival to NATO, and while Moscow has been blamed for inciting separatist violence in Georgia and Ukraine better to control its weaker neighbours (actions that have caused consternation in China), the US does not see Russia as a military threat (except as a nuclear power whose capability has been eroded by the planned development of a European ballistic missile defence treaty which Russia initially showed interest in joining until it became clear that it could not obtain the necessary guarantees that NATO missiles would not target the Russian Federation itself). ${ }^{9}$

Russia's military power aside, the focus of Western concerns is the emergence of an informal alliance between Eurasian energy-exporting economies that is partially replicated in the formal structure of the SCO and the informal structure of the BRICS, which poses a greater challenge to Western hegemony (Chun 2013; cf. Mudunuru 2013). The correspondence between the formal/informal dimensions of this counterhegemonic bloc is imprecise, but it does not depend on shared commitment to an ideological vision of world order. Still less does it limit the foreign policy of its adherents in any binding sense beyond vague conceptions of 'mutual trust and advantage' in the charter of the SCO (the 'Shanghai spirit'), which is oriented more towards 'Asian' than 'Western' values. However, while this may evoke the Asian-African Bandung communiqué of 1955, the priority is economic growth rather than a common vision of development:

From the perspective of the Central Asian Republics, the framework of the SCO, which contains their traditional economic sponsor, Russia, and [...] China, is seen as an important source for economic investment to aid their ailing domestic economies. Reciprocally, the Chinese leadership considers the development of economic opportunities in Central Asia as a primary aim, including gaining access to raw materials. As part of its concentration on energy as an area of strategic importance during the last decade, the Russian leadership considers maintaining its position as the main economic trade partner of the former Soviet Republics and ensuring it has an important stake in the direction of oil and gas pipelines in the region as priorities.

(Aris 2011: 79) 
The reality is that the SCO is an expression of Eurasian multilateralism, and is the only regional intergovernmental organization in Eurasia that Russia does not dominate (Marketos 2009: 31). Unlike the CSTO and the new EEU, which are recognizably Russian-led institutions reflecting Moscow's security and trade priorities in the post-Soviet space, the SCO has evolved as a more legitimate intergovernmental structure, reflecting the interests of all its member states rather than those of an aspiring hegemon, one which allows Central Asian states to participate in 'generating regional approaches to cooperation and security on an equal basis with the larger powers [...] an opportunity that Central Asia has not had before in modern times' (ibid.: 33).

Although some Western-sponsored international NGOs express concern that the SCO exclusively comprises authoritarian postcommunist states with little or no commitment to democratic norms (World Democracy Forum 2008; Ambrosio 2008), and although the SCO ultimately serves to stabilize Sino-Russian hegemony in Eurasia, Marketos is doubtful whether this unifying factor could overcome the disparity between Chinese and Russian policy and the internal contradictions within the SCO as an organization that has failed to evolve into a strong institutionalized alliance. As one Chinese scholar argues, the reasons for this are clear: "Russia needs to assure its Central Asian partners that it is "keeping an eye" on China's intentions vis-à-vis the region and stands by to provide Central Asian states with diplomatic backing should they need it in relations with China' (Guang, cited in Marketos 2009: 58). At the same time, he adds, Chinese efforts to 'endow SCO bodies with even a restricted supranational mandate will meet with Russian resistance. Russia will strive to preserve the SCO's original design as an intergovernmental forum' (ibid.).

For Russia, the SCO provides a forum for pushing counterhegemonic agendas vis-à-vis the West, and there is no desire for it to evolve into a political or customs union dominated by China's overwhelming economic power, rendering Central Asia (and eventually Russia itself) helpless in trade negotiations with Beijing. Hence the SCO is more likely to evolve as a "balancing coalition' with China as the leading power, Russia as an influential secondtier power with control over vast energy resources, and the Central Asian states as outliers, which is capable of using 'military, economic, political and normative levers against the United States and its interests in Asia' (Sussex 2014: 74). Yet this countervailing potential cannot negate the diplomatic and military influence of the US in Asia, which is built not just on American 'imperialism' but on the active complicity of East Asian states which prefer to maintain a regional political order contingent on the 'absent superpower' rather than be forced to accept the strictures of a Sino-centric regional order (Goh 2013). Neither can it create the necessary economic sovereignty to support the emergence of a truly autonomous Eurasian geopolitical bloc capable of entirely resisting the financial encroachment of transnational capital (cf. Fotopoulos 2014). 
If therefore Eurasian political unification is a non-existent prospect, the practical issue confronting Western elites is the potential expansion of the SCO and its possible correlation with the counterhegemonic agendas of the BRICS economies, which have 'unsettled conventional wisdom and cast doubt on the US dollar's future as the world's leading reserve currency' (Rickards 2014: 146). These two issues are closely correlated and must be dealt with in tandem before analysing the growing tensions between the Anglosphere and the core states of the eurozone. Of principal concern is the expansion of the SCO to include Iran, India, Pakistan and Mongolia as full members, as well as the accession of Belarus, Sri Lanka and Turkey to 'dialogue partner status'. The strategic importance of the SCO increased dramatically in September 2014 with the agreement in Dushanbe to expand the organization in Asia, increasing its representative legitimacy while enabling the organization to impact more effectively on security developments in its core region (Tiezzi 2014). As scholars of European regionalism are aware, however, the expansion of any intergovernmental organization is likely to create increased complexity for existing members and dilute the capacity/willingness of the organization to act in a unified, coherent fashion.

International observers believe neither Russia nor China yet wishes to grant Iran member status because this would further complicate their already awkward relations with the West due to the existence of sanctions, but talks on Iran's inclusion demonstrate the extent of realignment since the Iraq war and the US financial crisis. This reflects above all the role of Russia, which has been driving the SCO's enlargement as Eurasian economies increase their gold reserves in anticipation of a faltering dollar. However, the inclusion of Iran is in the interests of China, which has quietly increased its influence in MENA through its patronage of Iran in defiance of Western efforts to isolate the Islamic Republic. As one observer argues:

China's interest in absorbing the Middle East into her sphere of influence is obvious, given her current and future energy requirements; but she will also want to tap into the enormous wealth of the region. Her link into it is through Iran [...] to which she provided support during the Ahmadinejad years. One can only speculate about the degree of Chinese influence behind Iranian political developments, with Iran now aligning herself with China's view that trade matters more than belligerence with her perceived enemies. However, if one acknowledges China's strategic and trade interests, there is a ready explanation behind Iran's diplomatic moves to heal the rift with Saudi Arabia and other members of the Gulf Cooperation Council.

(Macleod 2013: 1)

This helps to explain the partial de-escalation of antagonistic rhetoric between Iran and its Arab neighbours, which remain fearful of Iran's nuclear aspirations and influence in the Gulf, yet are aware that deepening ties with 
Iran would balance Saudi hegemony in the region, introducing a 'second axis to the GCC evolution and change its outlook from security to economic growth and development' (Al Mukhaini 2014). It is mistaken for the US to view China or Russia as simply a threat to its commercial interests in the Middle East because their primary interests are also commercial:

while China's and Russia's increasing involvements in the region undoubtedly present a challenge to US and broader western hegemony, some care needs to be taken in interpreting the nature of these rivalries. Precisely because of the highly internationalized structure of the world market, all major states - including China and Russia - are deeply enmeshed in mutual trade and capital flows, sharing a common interest in the stability of global capitalism.

(Hanieh 2013: 44)

For China, in particular, the priority is to promote regional stability as the US begins to disengage from conflicts in the region, although China's hopes for stability in Syria and Iraq have been undermined by spillover effects from the Syrian civil war and the violence of the ISIL (Islamic State of Iraq and the Levant) insurgency which has created opportunities for closer military ties between Moscow and Baghdad, ${ }^{10}$ leading the US to return to Iraq to assist the Iraqi government with airstrikes following accusations of pusillanimity by Saudi leaders over America's 'lamentable' handling of events in the region (Al Faisal 2013), and fears over the emergence of an Iranian-dominated Shia energy bloc with geopolitical ties to Russia and China (Weiler 2014; Minin 2013). The US, for its part, is keenly aware that the foundations of the USSaudi alliance that created and sustained the petrodollar cartel have been eroded as the Saudis develop a leadership role in the GCC (in competition with Qatar), while pursuing a more active role as a global and regional force (cf. Gause 2011; Koch 2011). Arab states like Saudi Arabia and Syria have indicated a growing desire to trade with China, leading some observers to argue that the geopolitical chaos created by the fallout from the 'Arab Spring' has forced China to rethink its long-term strategy of forging a New Silk Road linking the economies of Asia and the Middle East (Chaziza 2013).

Although Iran's accession to the SCO is significant, the inclusion of India and Pakistan is a more logical geographical extension of the SCO into Southern Asia where a range of security issues require the attention of the international community. As Aris argues, there are huge potential benefits for increased cooperation between India and SCO members which would intensify existing trade and security ties between Russia, China and India within a new Eurasian 'security triangle', yet the inclusion of India as a democratic state could shift the emphasis of the SCO away from its core concerns (regime security) and alter the identity of the organization (Aris 2011: 160-8). The alignment of India towards the Eurasian 'strategic triangle' is a consequence of the election of the nationalist BJP Indian leader, Nerendra Modi, who has 


\section{0}

shown more willingness to enter into dialogue with China, as reflected in his bilateral meeting with Xi Jinping before the BRICS summit in July 2014 where China's president invited the Indian prime minister to resolve outstanding 'boundary issues', deepen India's engagement with the SCO, and attend the leaders' meeting of APEC states in Beijing in November 2014 - the last of which, we noted in Chapter 6, is opposed by the US.

For the US, India's accession is a diplomatic blow that could decisively tilt the balance of power as well as the balance of world opinion among developing countries away from the West, while forcing India to make more complex strategic calculations in decisions on foreign policy. From an Indian perspective, India's accession to the SCO brings it closer to the three countries the US wants to 'distance from its allies' (Russia, China and Iran), which will 'upset fence-sitters in the US establishment already unsure of the fruits of courting India over the past decade' (Kasturi 2014; cf. Rozin 2014). In addition to joining the SCO, India's alignment with Russia and China in the BRICS represents a powerful expression of countervailing power in a posthegemonic multipolar world, for it is this transregional economic bloc that seeks to 'reconfigure the world', to bring about an end to dollar hegemony and to challenge the predominance of Western values in global affairs:

Two processes are exerting definitive influences over the current global geopolitical dynamics. On the one hand, attempts are [being] made to establish - regardless of the imminent human costs - a unipolar world order propped up by financial and military might $[\ldots]$ On the other hand, the contours of an alternative world order offering greater fairness, rooted in different philosophies of individual existence, and based on its own economic and social order are increasingly visible. Since individual countries and national governments are defenceless at the face of the global financial centres, civilizations have to take over the leading role in the struggle for the survival of mankind, and the advent of [the] BRICS, along with its potential partner - the Shanghai Cooperation Organization, reflects one of the first initiatives of the kind. Interestingly, due to profound geopolitical reasons the civilizations now moving to the front stage are oriental and carry essentially non-Western values, moral norms, and forms of social organization.

(Ivashov 2011: 1)

Although the tone of this analysis is polemical, the political and economic implications of the challenge posed by the BRICS to Western economic hegemony are understood perfectly clearly by Western commentators, including Rickards, who notes that BRICS leaders are developing 'radical new positions' on five key issues confronting the world in a transitional period, namely voting rights in the IMF, voting in the $\mathrm{UN}$, multilateral assistance, international development, and global reserve composition (Rickards 2014: 147). He also notes that the BRICS mission statement calls for 'nothing less than a 
rethinking or overturning of the post-Second World War arrangements made at Bretton Woods and San Francisco that led to the original formation of the IMF, World Bank and the United Nations' (ibid.). In the absence of meaningful reform, the 'BRICS will take concrete steps to create their own institutions to perform their functions on a regional basis. The evolution of such institutions would inevitably entail a diminution in the role of the institutions they were meant to replace' (ibid.).

This is a threat the Anglosphere cannot ignore, for while Western media devote little coverage to BRICS announcements, while Russian and Chinese intentions are often misrepresented, and while understanding of the BRICS is limited in the West, alignment between the SCO and BRICS constitutes a counterhegemonic challenge to Western leadership in IFIs and America's hold over the global monetary system, exemplified by the decision by Russian and Chinese banks to facilitate Iranian hard currency transactions in defiance of Western sanctions on Iran and Iran's forced exclusion from international payments systems (Rickards 2014: 152). This example indicates the interrelation between financial and geopolitical power that underpins the transnational commodity form of money capital and the vulnerability of the US dollar as rival articulations of international monetary power compete for the confidence of investors and sovereign reserve holders. It also explains the material determination of the US to retaliate against plans for a BRICS reserve currency in the aftermath of its diplomatic retreat over intervention in Syria, for at stake is nothing less than Western control over the petrodollar system and America's power to print the currency in which international energy trades are denominated - without which the Anglo-American financial elite can no longer exert control over the future development of globalization.

As Eurasian economies add their weight to the Chinese-Russian alliance against Anglo-American financial hegemony, new combinations of financial and military action will inevitably be deployed to defend the status quo and prevent a loss of US dominance in global energy markets and energy transportation routes linking Europe, Asia and the Middle East (cf. Schortgen 2013). It is no longer possible to make sense of geopolitical developments in Eurasia unless we are prepared to link seemingly unconnected events across the region to the broader questions of energy and international monetary power - in particular, the determination of non-western powers to prepare for the contingencies of global monetary reset. After backing away from conflict in Syria in September 2013 and accepting a Russian-led diplomatic solution to the crisis, the US gained time to consider its options. Yet this rare display of multilateralism conceded strategic gains to a counterhegemonic coalition which has enabled Iran to reduce its diplomatic isolation by leveraging its position as defender of Syrian sovereignty and patron of the Hezbollah militia that turned the tide of the conflict in Syria in 2013. It is possible that the coup d'état in Kiev in February 2014 was aimed at punishing Russia for its support of Syria and for Iran's rise as a regional force in the Middle East, 'paving the way for a renewed attempt to topple the Syrian regime of President Bashar al- 


\section{2}

Assad' (Shaoul 2014). Syria matters, he adds, as it houses a major Russian naval base and 'occupies a strategically important position on the eastern Mediterranean, linking it to Central Asia and the Far East' (ibid.).

In reality, the actions of the US and its allies in Syria and Ukraine demonstrate that even where NATO cannot intervene directly, the West will attempt to force developments on the ground by using private security firms or backing the most reactionary social elements against regional leaders who ally with non-Western powers. In Syria the strategy of the West is to weaken the Russian and Iranian-backed government by supporting moderate Sunni rebels, while 'allowing' Saudi Arabia and Qatar to provide financial support for ISIL as a lever to pressure the Shi'ite governments of Iran, Iraq and Syria (Blair 2014). In Ukraine, on the other hand, Western strategy is to draw Russia into a land invasion of eastern Ukraine through acts of provocation which Russia has resisted, opting instead to provide aid to level the military balance and accelerate peace talks between Kiev and pro-Russian separatists.

The conflicts in Syria and Ukraine raise questions about whether efforts to forge a security order in Eurasia independent of the US will be blocked by the latter's desire to remain geopolitically relevant. For some it is only a matter of time before conflict erupts between NATO and Russia (Dugin 2014), while China's monetary ambitions could trigger a currency or trade war (Mirhaydari 2014). While enlightened observers in the US recognize that the West can no longer afford to think in Cold War terms (Hanson 1996), this type of progressive thinking is hardly shared by Western security elites eager to counter the disintegrative tendencies within NATO, to restrict Russian/Chinese political influence in the Middle East, and to preserve Western geostrategic control over energy transportation routes. The decision by the CIA to support the Euromaidan protests in Ukraine indicates the offensive intent of the Anglosphere confronted by the international financial profile of the BRICS and Russia's soft-power rebranding. ${ }^{11}$ Not only did the US help facilitate a coup d'état against Yanukovych by supporting neo-fascist forces, but it also reopened the question of European security, generating calls from NATO leaders for military spending to meet the 'Russian threat', and sanctions to punish Russian leaders like Igor Sechin who are planning a Eurasian energy trading system to break the monopoly of the petrodollar cartel in global energy markets (Durden 2014; Sandford 2014; Weiler 2014).

\section{German Europe}

A further - if somewhat less dramatic - challenge to the transnational leadership of the Anglosphere stems from the unanticipated growth of German political and economic power as the dominant state in the EU in the wake of the eurozone crisis - a crisis that threatened in 2011-12 to push Italy and Spain towards sovereign default and to undermine the supranational institutions of the EU, allowing Eurosceptics in the UK to claim vindication for their visceral opposition to the European single currency. Yet the stabilization 
of the eurozone under German leadership has created new opportunities for supranational integration between member states through the introduction of tighter fiscal rules to regulate the budgets of member states and reduce the potential for debt to undermine the financial stability of the Union. This has increased Germany's financial authority within the EU to the chagrin of France and the 'Club Med' economies, as the UK frets at the sidelines over the deflationary risks posed by a commitment to austerity and the subtle resurgence of German power in Europe. What is unclear, however, is the likely impact of Germany's increasing geoeconomic power and diplomatic influence in the EU for the foreign and defence policy of the Federal Republic as a member of the NATO alliance, a policy which some analysts argue is entering a period of transition following Germany's decision to oppose (in solidarity with France) regime change in Iraq in 2003 and to abstain (in opposition to France) over regime change in Libya in 2011 (Heymanns 2013).

Some 25 years after reunification, German capital stands poised to reap the benefit of the shifting balance of power in the global economy, with new opportunities for expansion into Eastern and Southern Europe, western Russia, the Caucasus and the Middle East, as German corporate-state elites cautiously begin to prepare the nation to assume a more proactive role in international affairs. Yet contrary to alarmist voices, it is wrong to assume that stabilization of the euro has given Germany a 'free hand' in the EU, for the political risks entailed in imposing austerity have been great, and Greece's threatened exit from the eurozone would be catastrophic for Berlin's hard-won reputation for sound moral-political judgement (Lang 2013).

It is not merely a question of German leadership of Europe but rather what type of Europe Germany wishes to create as the US begins to disengage and shift its attention to the Asia-Pacific region - to the consternation of Germany's EU partners, which fear the possible consequences of a pan-European political order with Germany as its hub (Navarro 2011). However, just as it is mistaken to describe Germany as a 'tamed power' in Europe without a meaningful foreign policy (Bulmer \& Paterson 2010; cf. Katzenstein 1997), so too is it simplistic to see Germany as a threat to its neighbours, even if historical memories of assertive German leadership colour perceptions. As Beck argues, 'everyone knows it, yet to articulate it is to break a taboo: Europe has become German. Nobody intended this but [...] Germany's economic power has catapulted it into becoming the most important great power in Europe' (Beck 2012: 7).

On this view, German reunification and German leadership in the eurozone crisis have increased the incentive for Germany to advance its national goals by accepting a form of 'institutional lock-in' (where a dominant state asserts its leadership by agreeing to engage with rules-based institutions while retaining the prerogative to alter the terms of multilateral engagement if necessary), as a result of which Thomas Mann's vision of Europe has come a step closer to realization, namely a Europeanized Germany as the hub of a German Europe organized into a coherent federation. For many Europeans, 
of course, the optimism and subtlety of this argument are lost, as Berlin's leadership in the eurozone crisis has created serious divisions in the EU - not merely between creditor and debtor states (particularly Greece and Italy whose political sovereignty has been compromised), but between European governments that support the emerging 'Berlin consensus' and European voters across the EU (including Germany itself) who manifestly do not.

Yet Germany's stabilization of the euro through the ECB has imposed structural adjustments on southern eurozone states, designed to support a return to growth across the currency area without resorting to the excessive monetary expansion used by the US and UK as a means to disguise the hollowness of economic 'recovery' after the global financial crisis. So successful has the stabilization of the euro been since 2012 that the currency area is rapidly becoming a major destination for FDI from China and ASEAN economies which consider the euro a safe alternative to the dollar, and Berlin's determination to preserve the single currency at all costs clearly demonstrates that for Germany the survival of the euro has always been more than simply a question of monetary policy, reflecting the essential character of the EU as a political project to extend German fiscal and monetary practices to the eurozone in its entirety (Bulmer \& Paterson 2010).

Yet two basic questions remain, namely: (i) does this 'German Europe' represent a new form of counterhegemonic regionalism in potential conflict with the transnationally constituted geopolitical and financial power of the Anglosphere; and (ii) is Germany pulling away from NATO in favour of working towards a more autonomous foreign and defence policy - particularly in the light of the NSA espionage scandal and the desire of the US to impose sanctions on Germany's key trading partner, Russia? Although a complete answer to this question would require a separate study, evidence suggests that while Germany has shown itself willing to challenge American leadership by refusing to cooperate with NATO or by pursuing its own unilateral priorities in specific conflict scenarios, despite pressure from NATO allies like France, Italy and the UK, it is reluctant to assume a visible or proactive leadership role in managing threats to European security which might undermine its reputation for cooperative multilateralism and conditional support for the EU as a security actor (cf. Biscop \& Renard 2010).

Bulmer and Paterson are correct to argue that in response to its emerging power in the EU and increasing geoeconomic might, Germany is moving from a condition of 'tamed power' to 'normalization', expressed as the 'willingness to undertake unilateral demarches, the adoption of a discourse of national interest in policy statements, and the use of power to keep certain items off the agenda' (Bulmer \& Paterson 2010: 1059). Such a transition involves difficult choices, where the "hard edges" of power are no longer softened by the device of being able to present national interests as simultaneously European ones', leading to a 'rebalancing away from indirect institutional power to the hard bargaining of agent power' (ibid.: 1060). The significance of Germany's institutional power can be seen in the adoption by 
the ECB of the Bundesbank's mandate to maintain price stability and to impose fiscal discipline on spendthrift politicians (Abdelal \& Krotz 2014: 136). The significance of Germany's new 'agent power', however, can also be seen in the diplomatic standoff between Berlin and London in June 2014 over the appointment of Jean-Claude Juncker as president-elect of the European Commission - a decision that UK Prime Minister David Cameron wanted to be taken by the European Council (an intergovernmental body) rather than the European Parliament (a supranational body). Cameron issued a variety of implied threats in order to force the issue, but German Chancellor Angela Merkel dismissed British protests with a vague pledge to support UK reform proposals for the EU. Operating outside the eurozone, however, the UK has forfeited influence over the determination of policy and personnel, while German power has increased in the aftermath of the eurozone crisis and Berlin seems unwilling to return to its earlier habit of deference towards the UK and France.

To understand the strategic priorities of the Federal Republic, however, we must first understand the importance of 'exporting stability' (Stabilitätsexport) for Germany as the largest economy in Europe with vulnerable borders, and the effect of Germany's rising geoeconomic power on geopolitical thinking in the new Federal Chancellery and Foreign Office in Berlin.

After reunification, German foreign policy was dominated by two key developments, first the eastward expansion of NATO (and subsequently the EU), and second conflict in the western Balkans - security issues that continue to create instability in Europe's eastern and south-eastern periphery. For historic reasons strategic geopolitics in the tradition of Mackinder and Haushofer are discredited in Germany, and the new Berlin Republic has dissociated itself from the disastrous consequences of the radicalization of German foreign policy after the fall of Bismarck in 1890 and the rise of fascism in the 1930 s.

This position is supported by a majority of Germans (61 per cent), who reject involvement in NATO deployments driven by Realpolitik (Körber-Stiftung 2014), and domestic opinion is considered by Germany's foreign and defence elite to be the main constraint on increased cooperation with and participation in NATO security operations. Even where Germany has agreed to participate in out-of-area operations (in Kosovo and Afghanistan), it has offered only limited support in line with its Basic Law, which requires strict parliamentary oversight of the activities of German armed forces abroad. This has created friction between Berlin and Washington reminiscent of the antipathy that flared between France and the US in the 1960s when Charles de Gaulle withdrew French forces from NATO, and has led pro-US German observers to criticize the 'friendly disinterest' of Germany's elites towards military affairs, and Germany's unwillingness to fulfil its role as 'leader of the European pillar of the Alliance' (Bunde 2013).

Others point out that if Germany wishes to benefit from a global economy, it must expect to invest in security to defend open borders - in addition to 


\section{6}

Capitalist geopolitics

ratifying the TTIP - for America's 'involvement with the EU depends in large part on its relations with Europe's major countries including Germany, the symbol of a once divided Europe and a benefactor of its success' (Janes \& Nicholson 2014: 2). This can be read in many ways, but it clearly indicates the anxiety felt towards the declining appeal of NATO, and is typical of rhetoric used by US-funded NGOs which, since Germany's abstention over intervention in Libya, have targeted the German elite in an effort to generate support for the globalization of NATO as an alliance that is undermined by lack of consensus and common purpose, and which must either secure a global mandate to intervene 'out of area' or fade into geopolitical irrelevance (cf. Kober 2009; Navarro 2011). From a US perspective, Germany is the 'weak link' in the Atlantic security community, and every effort is made through the cultivation of pro-American opinion in the German media to deter the Berlin corporate and political class from forging closer ties with Russia and China at the expense of the transatlantic alliance (Ulfkotte 2014).

Although Germans view NATO as an 'organization from the past' (Sauer 2014), Washington's tactic is to 'shame' Germany's elites into aligning domestic opinion away from pacifism towards geopolitical engagement and increased defence spending. ${ }^{12}$ This tactic has not been without effect, as evidenced by the speech delivered at the Munich Security Conference in January 2014 by Federal President Joachim Gauck, who stressed the need for Germany to contribute to and participate in more enthusiastically the defence of European and global security in an increasingly risk-prone international environment (Müller 2014). Gauck caused controversy when he declared that not only should Germans be 'ready to do more', but that 'we are moving towards a form of responsibility to which we are so far unaccustomed' (Frankfurter Allgemeine Zeitung 2014). ${ }^{13}$

This change of tone in foreign and security policy is further evidenced by the strident rhetoric of former Defence Minister Thomas de Maizière, who impressed his NATO counterparts in 2013 with proposals for reform of the military alliance that would see all member states develop and finance sovereign military capabilities collectively rather than individually - in country clusters - allowing Germany greater influence over the smaller NATO member states in its region (Heymanns 2013). Maizière has also supported calls for parliamentary restrictions on the Bundeswehr (armed forces) to be relaxed or abolished, beginning with German operations organized under the auspices of the EU, for example, in Kosovo where Germany is the main EU Investitionspartner, and where the breakaway Albanian-majority statelet is part of a developing economic network linking Central Europe to the western Balkans. ${ }^{14}$

Such changes in a country's security and foreign policy do not happen spontaneously; rather, they occur in periods of conflict and change when geopolitical opportunities arise to assert greater influence - as Germany discovered in 1999 following NATO's bombing of Serbia and occupation of Kosovo (a template for 'humanitarian interventions' in Iraq and Libya which 
Germany declined to support), or as a result of attempts by transnational elites to undermine the political consensus within countries and manipulate its evolution towards adoption of more hard-line positions. In the former case, it is clear Germany used the opportunity of war in Kosovo to advance its own geopolitical interests in the Balkans, where the EU has taken over responsibility for security from the UN and where the BND is active in protecting German interests (Johnstone 2002; cf. Fitsanakis 2008). In the latter case, it is clear transatlantic elites exploited the crisis in Ukraine not only to reduce German scepticism towards military engagement but to challenge Germany's partnership with Russia and generate support for a revision of the 1997 Founding Act. Indeed, since the formation of anti-communist 'staybehind armies' in occupied Germany in the 1950s (Müller 1991), the US, UK and France have shown a consistent willingness to appeal to the most reactionary elements in the German establishment to advance Western financial and geopolitical interests, which in the present global confrontation are best served by German support for the pro-US regime in Keiv and the creation of a new cordon sanitaire from the Baltic to the Black Sea.

The litmus test of Germany's evolving foreign and security policy in the near periphery of the EU is the reaction of German corporate-state elites and German voters to the crisis in Ukraine and the call for sanctions against Russia. In contrast with the near-hysterical reaction of governments in Romania and Poland, and the siren calls of the neoconservative anti-Russia lobby in the US which has used the crisis to demonize Russia using tactics reminiscent of the crisis in Georgia in 2008 (cf. Tsyganov 2009), Germany has refused to engage in wild denunciations of Russian foreign and security policy in Crimea and eastern Ukraine, and has been slow to agree to economic sanctions which have adversely affected the interests of German corporate investors in Russia who do business in the US (Schepp \& Schmergal 2014). This reluctance has resulted in accusations that Germany is dominated by Putin-Versteher ('Putin sympathizers') who underestimate the authoritarian character of Putin's government and the political risks of 'appeasing' Moscow (Adomeit 2014).

This criticism is reminiscent of the negative publicity surrounding the $€ 8.8$ billion Nord Stream project between Gazprom and Ruhrgas (E.ON), which led to the opening in September 2011 of a pipeline under the Baltic Sea, bypassing the existing Eastern European transit route through Ukraine, thereby enabling Germany to secure its gas supplies from Russia independently of any disputes that may flare up between Russia and Ukraine. Germany's desire to secure its own independent energy supplies may or may not be read as evidence of counterhegemonic tendencies in its foreign policy, but the evidence suggests that Berlin is concerned primarily with its own energy interests rather than those of its eastern neighbours, and is prepared to act unilaterally and geopolitically in defence of its energy interests - even at the risk of being accused of promoting a 'Berlin-Moscow axis' at odds with German membership of NATO. 
Hoffmann develops this point further in his analysis of German national security policy, arguing that after a long period of dormancy the geopolitical dimension of German energy policy has been 'suddenly discovered'. In his view, German foreign policy is defined by cooperative multilateralism with Western partners, commitment (Bindung) towards Russia for long-term energy security, and regional diversification of energy imports (Hoffmann 2012: 246). However, while Germany needs Russia, it seeks to avoid dependence on Russian gas imports, a fact demonstrated by its participation in the EU's Central Asia Initiative. Despite Germany's renewed desire to act in a unilateral capacity, it remains committed to collective EU efforts because it is only via a 'European framework that Germany's geopolitical interests can be realized' (ibid.: 320). Putin-Versteher may be more voluble in Germany, but the Berlin Republic remains closer than critics realize to US policy on Ukraine, and Chancellor Merkel's approach to the crisis has been driven by a desire to promote EU investment in its near periphery through the ENP without undermining Germany's partnership with Russia, while simultaneously being seen to support US attempts to punish Russia over Crimea and for daring to challenge the petrodollar cartel. However, if US foreign policy 'were to change toward a more confrontationist or containment approach, trouble in the transatlantic relationship would be brewing' (Adomeit 2014: 2). The accuracy of this prediction can be seen in the decision by Angela Merkel and François Hollande to break ranks with the Anglosphere and negotiate a second Minsk ceasefire agreement for Ukraine in February 2015, rejecting the belligerent threats of US leaders to arm the Ukrainian military.

\section{Conclusion}

Power transition theorists like to maintain that the threat of systemic war escalates when a 'single dissatisfied great power's capabilities catch up to or pass the capabilities of the traditional dominant power that is now in relative decline. During this power transition, the challenger sees an opportunity to defeat the dominant power and establish a new order' (Rasler \& Thompson 2012: 99). For US students of international security studies it is axiomatic that China - like Germany a century ago - will seek to acquire the capability to challenge the roaming power of the US in Asia, to exert control over its 'near seas', to promote Sino-centric regional economic integration, and to defend and advance Chinese sovereignty claims while sustaining harmonious relations with its Asian neighbours and avoiding conflict with America as the latter increases its military presence in the Pacific (Glaser 2014). However, while China's rise is already creating unease among its Asian neighbours whose ambivalence towards America's military presence in the Asia-Pacific is tempered by anxiety about Chinese territorial aspirations - it is doubtful whether China's corporate-state elites will have the opportunity to emulate the example of American hegemony. Even if Mearsheimer is right - that one cannot predict the intentions of China's leaders in the future - it is clear 
China is only one great power among many in an emerging complex multipolar system which (in contrast to the world the US inherited in 1945) will materially constrain China's ambitions (Moens 2012: 107).

Yet, as we have argued, the future of world order in a globally integrated economy will be determined less by China's capacity to grow peacefully than by unwillingness in the West to accept a reset of the international monetary system and a consequent diminution of its transnational financial power. To sustain this power in international politics, the US and its allies are accustomed to acting unilaterally to suppress regional contenders and degrade local sovereignties to maximize the mobility of finance capital concentrated in North America, Japan and the EU. Western financial power is supported by the formal military alliance of NATO, but also by the informal interventionist power of the US, UK, France, Israel and Australia as military actors in their own right. It is further supported by the transnational signals intelligence capacity of 'ECHELON' centred on the NSA and GCHQ (which continues to deny Germany full membership and is a source of tension in transatlantic relations). ${ }^{15}$ Although NATO is an institutional relic of the Cold War, internally divided and unable to prevail in unconventional warfare, it remains a symbol of Western power and is quick to assume the mantle of the international community', even if on closer inspection it is a 'military club of richworld states and their satellites used to enforce western strategic and economic interests' (Milne 2014: 2).

America's pivot towards Asia (locating 60 per cent of its military power in the region) constitutes an attempt to remain geopolitically relevant by emphasizing the threat posed by Chinese military modernization. Yet China is not yet a direct threat to US interests in the eastern Pacific because it can only hope to increase the marginal costs of America's presence in the region rather than achieve naval parity (Monteiro 2014). Beyond its need for monetary reset, China's geostrategic priority is the security of its maritime trade and energy imports, and it is precisely this vulnerability that the US may seek to exploit to constrain China in a conflict scenario. ${ }^{16}$

The question remains, however, whether international society - to the extent that such a collective entity exists as a pluralistic aggregation beyond the liberal-universalist imaginary - is capable of managing the transition to a multipolar global growth system and thus to address the geopolitical tensions created by capitalism. Multilateralism is an institutional form of international praxis based on 'coordinating principles between three or more states in accordance with certain principles' (Ruggie 1993: 8), but the 'real test of multilateralism as an international practice is the extent to which it shapes institutions and rules, frames international norms and values, and affects behaviour, especially of key actors' (Smith 2014: 10). At present, argues Smith, the US views itself as a 'rule maker' and regards China and Russia as 'rule takers' reluctant or otherwise; but if the Washington consensus gives way to decentred globalism, the question will be how the US adjusts to its status as a declining world power among great powers. 
As the permissive environment of the 1990s recedes, realists embrace a return to multipolarity, yet a note of caution is advisable lest we succumb to the idealism of those like Zakaria (2011) who predict a new era of multilateralism in global politics; or Buzan who argues that there is no "need for the US to see off challengers to its sole superpower status, first because there are none, and, second, because that status is anyway indefensible both socially and materially' (Buzan 2011: 21); or Ikenberry, who notes that all emerging powers are capitalist and, though not 'united by a common principled belief in a postliberal world order [...] are all very much inside the existing order and integrated in various ways into existing governance institutions' (Ikenberry 2013: 96). Ikenberry in particular compares the US-centric order of the late twentieth century to ownership of a privately owned corporation which as a result of globalization is now 'going public'. The goal for the West, he insists, is to manage this historic transition while retaining a 'seat on the board', though he fails to register how this transition is complicated by the decline of the US dollar as the monetary basis of Western financial power and the material threat posed by reserve currency diversification and non-dollardenominated trade for the transnational security and energy networks that sustain this power.

This, of course, is hardly surprising, given the lack of attention paid by IR to the determining role of capital which presupposes its own universality and self-existence in the unfolding drama of globalization. Although complex interdependence reduces the likelihood of great power war, it is uncertain whether global convergence will lead to peaceful multilateralism in a multipolar global growth system structured by rival corporate power interests. On the contrary, as it becomes apparent that Western corporate-state elites are unwilling to hand over 'seats on the board' to financial elites from emerging economies and accept the verdict of history, the world is likely to witness a relative intensification of geopolitical rivalry as Eurasian and East Asian economies recalibrate their financial and monetary systems away from the direct influence of Western-led IFIs.

While liberal realists seek evidence to support the transition from international society to world society, forecasts of multilateral cooperation between interdependent states must be balanced against the persistence of antagonistic competition between regional and transregional capitalist blocs - located principally in the West and Eurasia. There are few reasons to expect the US to relinquish its embedded institutional power or to abandon unilateralism, suggesting a continued or expanded occurrence of conflicts between the declining hegemon and 'recalcitrant' regional powers which opt for 'extreme self-help' or align themselves with revisionist great powers. Monteiro (2014) suggests rightly that the potential for the declining hegemon to be drawn into regional conflicts remains high as long as the incentive for 'extreme self-help' exists for regional powers, yet the premise of unipolarity itself is faulty and is clearly contradicted by the capacity of 'recalcitrant' powers like Iran to leverage their geopolitical security by aligning with great powers like Russia 
and China against the West's attempts to isolate the Islamic Republic. Although Israel retains the option of preventive war to delay Teheran's bid for military hegemony in the Gulf, Iran's economic and political interests in the greater Middle East have been successfully defended and advanced through deft cooperation with Syria, Russia and China against US/Saudi foreign policy, suggesting the growing irrelevance of America's 'unipolar moment' beyond the seminar rooms of Ivy League graduate schools.

Anglo-American IR scholars are correct to argue that emerging great powers seek accommodation with the West, yet are correspondingly blind to the refusal of the Anglosphere as a transnationally constituted geopolitical force to accommodate itself to the realities of global economic convergence. What is missing in many analyses is acknowledgment of the impact of relative decline for the US in a global capitalist economy where the rapid (yet uneven) development of emerging economies contrasts sharply with the US, where a corporate oligarchy depends on direct financial life support from the Federal Reserve and the destabilization of regional economies that resist the penetration of Western capital.

Above all, however, Western transnational foreign policy is driven by fears that China and Russia are preparing for a major loss of international confidence in the dollar, exemplified by the decision by BRICS economies to develop alternatives to the Western-dominated global financial and payments system in defiance of the Anglo-American elite. However, while the Anglosphere is opposed to monetary reset, given there is no way to resolve the fiscal crisis of the US state without also generating hyperinflation, Western corporate-state elites may already have privately concluded that the short-term cost of delaying dollar collapse by manipulating gold paper markets (allowing China to acquire gold cheaply while continuing to hold US debt in return) are less serious than the catastrophic risk of a disorderly default as investors abandon US securities for alternative havens. China and Russia are preparing for the remonetization of gold as an integral component of monetary reset, and despite the effect of quantitative easing and economic sanctions are relatively less vulnerable to the financial statecraft of Anglo-American capital. Tacitly supported by China, Russia is pursuing a high-risk strategy in this respect, namely to sell oil only for physical gold, thus re-opening the 'gold window' through trade rather than through the currency markets without Western permission. This strategy may succeed, argues Kalinichenko, regardless of whether the West agrees to pay for energy in gold:

Since Russia has a constant flow of dollars from the sale of oil and gas, it will be able to convert these dollars to buy gold at current gold prices, depressed by all means by the West [...] Using the mechanism of active withdrawal from the market of one financial asset artificially lowered by the West (gold) in exchange for another financial asset artificially inflated by the West (USD), Putin has thereby started the countdown to the end of the world hegemony of petrodollar [...] The West can spend as much 
of its efforts and resources to artificially increase the purchasing power of the dollar, lower oil prices and artificially lower the purchasing power of gold. The problem of the West is that the stocks of physical gold in possession of the West are not unlimited. Therefore, the more the West devalues oil and gold against the US dollar, the faster it loses devaluing Gold from its not infinite reserves.

(Kalinichenko 2014: 1)

This strategy is intended to weaken the global hegemony of the petrodollar and turn the US currency into an intermediate means of payment for an asset with no counterparty liability - physical gold. Predictably, this has led to retaliation in the form of US-Saudi cooperation to suppress the price of oil in an attempt to undermine the Russian economy further, leading to a 41 per cent decline in the value of the rouble in December 2014 and the replacement of leading figures at the Central Bank of Russia (Fedorinova 2015).

Although Russia under Putin has successfully overcome the bitter legacy of economic collapse, sovereign default and internal conflict, and has willingly engaged with the West and adapted to new international institutional norms, Moscow's attempt to rebrand the country as a resurgent economic power with vital geopolitical interests in Eurasia has failed in Western eyes because the US cannot tolerate any challenge to the transnational geopolitical agency of Western financial and security interests. As Ishchenko (2015: 2) argues, 'at any given time Putin [has] engaged in precisely the level of confrontation with the United States that Russia could handle. If Russia isn't limiting the level of confrontation now, it means Putin believes that, in the war of sanctions, the war of nerves, the information war, the civil war in the Ukraine, and the economic war, Russia can win.' Washington, he adds, is not governed by fools, and US actions in Ukraine reflect a realization in the West that as the US declines Russia has become stronger, economically, militarily and diplomatically: 'This process was natural and impossible to arrest,' he argues, 'and we could have projected with a high degree of certainty that by 2020 to 2025 , without any confrontation, the period of US hegemony would have ended, and the United States would then be best advised to think about not how to rule the world, but how to stave off its own precipitous internal decline' (ibid.). While Russia and China need peace to realize their long term goals, therefore, the US needs perpetual conflict to push rising contenders off balance and delay a secular realignment of world order - even at the risk of igniting full-scale war in Europe.

Underlying the long-term decline of the US and UK is an accumulation crisis - a tendency towards overaccumulation that can 'never be eliminated' (Harvey 1989: 182). Overaccumulation, argues Harvey, is 'an eternal problem for any capitalist mode of production. The only question [...] is how the overaccumulation tendency can be expressed, contained, absorbed or managed in ways that do not threaten the capitalist social order' (ibid.). As we saw in Chapter 4 and Chapter 5, the contradictory logic of overaccumulation is 
increasingly mediated through the state form of capital along multiple spatial scales, and the intensified political management of transnational capital reflects the specific capacity of the financial circuit of states and IFIs to reproduce the political conditions necessary for the valorization of value through investment and speculation in established and emerging markets. Yet declining profitability and intercorporate rivalry are eroding the capacity of all states - particularly the US and UK - to accumulate value profitably, to resist deflationary pressures, and to control the direction of capital flows as once self-sustaining financial corporations demand increasing levels of structural support through state circuits of capital to sustain the accumulation of derivative values that generate the illusion of wealth - directly contradicting the neoliberal myth that society should be ordered through competitive 'marketbased mechanisms rather than state intervention' (Soederberg 2006: 111).

This, in turn, is undermining the fiscal integrity and stability of the US and UK, which are increasingly unable to contain reserve currency diversification and the speculative orientation of transnational capital towards emerging markets which offer investors more opportunities for profitable accumulation. Sparked by the refusal or inability of Western corporate-state elites to engineer structural reform of their banking systems, the accumulation crisis of Western capital is pushing Western corporate-state elites to shift the cost of devaluation elsewhere - onto emerging economies, workers and the poor. As the 'concentration and centralization of capital proceeds', argues Smith, 'the overaccumulation and devaluation of capital necessarily tends to occur on an ever more massive scale. Global turbulence and generalized economic insecurity increasingly become the normal state of affairs' (Smith 2003: 38). Although realists continue to insist that in an international system structured by anarchy states organize their security and prepare for war, making conflict likely even if states do not seek it, it is increasingly clear that the underlying structural cause of conflict in the international system is no longer geostrategic rivalry as such, but financial pressure to preserve the concentrated economic power and above-average earnings of dominant capital, particularly financialized corporations that benefit from the pro-liquidity policies and asset purchases of central banks, whose primary function is to maintain the existence of system-relevant institutions.

As liberal internationalism is gradually superseded, the old imperial illusions of the West increasingly resemble relics of nineteenth-century capitalism that no longer correspond to the complex realities of a multipolar global growth system characterized by new forms of uneven and combined development. Indeed, as Buck-Morss notes, for too many left-wing radical critics the term US hegemony 'stands in for all the evils of the world: economic, cultural and political. But it needs to be emphasized that none of the problems that concern us [...] would disappear even if the United States ceased to exist altogether' (Buck-Morss 2007: 440). While geopolitics has been defined historically by the logic of national security, capitalist geopolitics is ultimately defined by 'ruling class security' (Apeldoorn 2014), and even if organizations 


\section{Capitalist geopolitics}

like the SCO or BRICS present a counterhegemonic challenge to the West, they nevertheless exist in the first instance to provide a forum for co-managing the security of participating capitalist states whose domestic social and political regimes are far from progressive. From this perspective, the material-ideological structures of corporate capitalism are changing in form, but corporatism will not 'end' with the decline of the US from a world power to great power although reports indicate that corporate-state elites in the US itself are preparing for an upsurge of violence as the economy deteriorates and environmentalist opposition to corporate energy policy escalates (Gaist 2014; Ahmed 2013).

While transnational corporations headquartered in the West would prefer to lead global markets through peaceful, rules-based trade, as Cooke observes, "peaceful market domination has become more difficult as the US has declined economically in relation to emerging economies like China, India, Brazil, etc.' (Cooke 2013: 3). As the capacity of Western central banks to delay structural adjustment is eroded, as the material-economic structures of Western financial power are placed in question, and as revisionist economies challenge Western leadership in international financial institutions (or develop IFIs of their own), military force and other forms of statecraft will be called upon to undermine contenders, suppress local sovereignties and maintain access to resources necessary for the power of transnational capital. This indicates the essential unity of capitalist sovereignty and state power articulated in contemporary geopolitics - a transnational strategic practice that mirrors predatory corporate rivalry for control over global markets and which reproduces structural conditions for corporate oligarchy through the financial circuits of the national and transnational state form of capital.

\section{Notes}

1 An example of progressive interregionalism would be the developing ties between the EU and ASEAN. The EU is the largest investor in South-East Asia, and the EU is ASEAN's second largest trading partner after China. See Blankert (2012), who frames the relationship in positive terms as a 'natural partnership'.

2 Some observers, e.g. O'Brennan (2014), suggest that after the eurozone crisis external expansion of the EU is stalling - that is, the current project of integrating the smaller states of the western Balkans (former Yugoslavia) is flat-lining due to 'enlargement fatigue' on the part of EU member states, and a 'deficit of implementation' on the side of candidate states.

3 On the dual character of the European continent as a Euro-Atlantic/Euro-Asiatic geopolitical space, see Sava 2004.

4 The text of the 1997 'Founding Act on Mutual Relations, Cooperation and Security between NATO and the Russian Federation' can be found at www.nato. int/cps/en/natolive/official_texts_25468.htm.

5 On the normative deficit of US foreign policy, see Aslam (2013), who argues from an English School perspective that America fails to meet the criteria for great power responsibility in international society: the norm of legality, the norm of legitimacy, and the norm of prudence. 
6 For an alternative perspective on EU foreign and security policy, see Sjursen (2012), who argues that the EU is capable of rising above mere intergovernmentalism. See also the contributions in Telò \& Ponjaert 2013.

7 Pan and Chen argue that China's state elite is aware of the risks and opportunities of multipolarity, yet sees the current shift in world order away from Western hegemony as broadly positive because it has been conditioned by globalization and increasing interdependence which hypothetically reduce the potential for war. The official Chinese strategy is to promote what Qin Yaqing somewhat pompously terms 'relational governance', to manage international relations through a 'deliberative political and social arrangement in order to establish order, [...] conduct mutually beneficial cooperation, and build trust through the forming of common understanding of the social norms and human morality' (Pan \& Chen 2012: 72). The principal components of this strategy are 'partnership bilateralism' and 'tailored multilateralism'.

8 Kennan (1948) defined political warfare in a 1948 State Department memorandum as 'the logical application of Clausewitz's doctrine in time of peace [...] the employment of all the means at a nation's command, short of war, to achieve its national objectives'. For further details of current US thinking on the utility of political warfare, see Boot et al. 2013.

9 On the development of missile defence since the Cold War, see Futter 2013. Turnbull (2014) argues that the real focus of US ballistic missile defence operations is Asia rather than Europe.

10 In September 2014 Iraq took delivery of new Russian Pantsyr-S1 mobile shortrange air defence systems. See www.janes.com/article/43893/30-09-2014.

11 On the historical evolution of Russia's identity in international relations, see Taras 2013.

12 Deploying this tactic, Bunde argues: 'While the strategic community in Germany is mostly on the same page with international critics, Germany's international partners will have to target the political leadership - preferably along the lines suggested by the [Stiftung Wissenschaft \& Politik/German Marshall Fund] report and appeal to those traditions of the German strategic culture that they want to see strengthened. What they can thus do is to opt for a strategy of naming and shaming, basically letting the German government know that the only way to keep NATO relevant is to actually invest in and commit to its multilateral structures. This means more pooling and sharing, more common funding, and the ensuing commitment that these common resources can actually be used by NATO (or some of its allies) even if one ally has objections against a certain mission' (Bunde 2013: 3).

13 'Deutschland muss bereit sein, mehr zu tun [...] Wir sind auf dem Weg zu einer Form der Verantwortung, die wir noch nicht eingeübt haben.'

14 See the speech by Sigmar Gabriel, German Federal minister for economy and energy, 28 August 2014, to assembled business leaders, www.bmwi.de/DE/Service/ veranstaltungen.

15 On the EU investigation into ECHELON, which provides vital economic intelligence for Anglo-Saxon economies, see Schmid 2001 and Asser 2000; also see Bamford 2008.

16 Awareness of this vulnerability is driving Chinese investment in overland trade routes from the Indian Ocean to western China and the creation of port facilities in Asia (China's 'string of pearls') to protect its expanding global economic footprint (see Joshua 2013). China's acquisition of Gwadar port in Pakistan in February 2013 against US wishes is a case in point. The port - which the US previously sought for its own military purposes - provides China with a vital strategic asset in the Balochistan region of Pakistan, adjacent to the Strait of Hormuz, and is being linked by road to Kashgar in China. The deal also has implications for India, Iran and the United Arab Emirates (Mazhar et al. 2012; Sharma 2013). 


\section{Abbreviations}

ABF Asian Bond Fund Initiative

AIIB Asian Infrastructure Investment Bank

APEC Asia-Pacific Economic Cooperation

ASEAN Association of Southeast Asian Nations

BIS Bank for International Settlements

BJP Bharatiya Janata Party

BND Bundesnachtrichtendienst (German intelligence)

BRICS(A) Brazil, Russia, India, China, South Africa

CDU Christian Democrats

CEO chief executive officer

CIA Central Intelligence Agency

CIS Commonwealth of Independent States

CSTO Collective Security Treaty Organization

ECB European Central Bank

EEC European Economic Community

EEU Eurasian Economic Union

ENP European Neighbourhood Policy

EU European Union

FDI foreign direct investment

FIRE finance, insurance and real estate

FTA free trade agreement

G7 Group of Seven advanced economies

G20 Group of Twenty advanced and emerging economies

GCC Gulf Cooperation Council

GCHQ Government Communications Headquarters

GDP gross domestic product

IFI international financial institution

IMF International Monetary Fund

IPE international political economy

IR international relations

ISDS investor-state dispute settlement

M\&A merger and acquisition

MENA Middle East and North Africa region 
MFN most favoured nation

MNC multinational corporation

NAFTA North American Free Trade Agreement

NATO North Atlantic Treaty Organization

NGO nongovernmental organization

NSA National Security Agency

OECD Organisation for Economic Co-operation and Development

OPEC Organization of the Petroleum Exporting Countries

PFP Partnership for Peace

R\&D research and development

RTA regional trade agreement

SAP structural adjustment programme

SCO Shanghai Cooperation Organization

SDR special drawing right

SPD Social Democratic Party

TPP Transpacific Partnership

TTIP Transatlantic Trade and Investment Partnership

UN United Nations

US United States

USSR Union of Soviet Socialist Republics

WTO World Trade Organization 


\section{Bibliography}

Abdelal, R. and Krotz, K. (2014) 'Disjoining Partners: Europe and the American imperium', in L.W. Pauly and B.W. Jentleson (eds) Power in a Complex System, London: Routledge.

Adamo, F. (2001) 'Geopolitics and geoeconomics: from colonialism to globalism', in M. Antonsich et al. (eds) Europe between Political Geography and Geopolitics, English trans., Rome: Societa Geografica Italiana.

Adler, E. (1997) 'Seizing the middle ground: constructivism in world politics', European Journal of International Relations, 3, 3: 319-363.

Adomeit, H. (2014) 'Germany's Russia policy: comparative perspectives and consequences for transatlantic policy', American Institute for Contemporary German Studies, 29 May, www.aicgs.org/publications.

Agamben, G. (1993) The Coming Community, English trans., Minneapolis, MA: University of Minnesota Press.

Agamben, G. (1998) Homo Sacer: Sovereign Power and Bare Life, English trans., Stanford: Stanford University Press.

Agamben, G. (2005) State of Exception, English trans., Chicago: Chicago University Press.

Agathangelou, A.M. and Ling, L.H.M. (2009) Transforming World Politics: From Empire to Multiple Worlds, London: Routledge.

Aglietta, M. (1979) A Theory of Capitalist Regulation, English trans., London: New Left Books.

Agnew, J. (2005) Hegemony: The New Shape of Global Power, Philadelphia: Temple University Press.

Ahmad, A. (2004) 'Imperialism of our time', in L. Panitch and C. Leys (eds) The New Imperial Challenge: Socialist Register 2004, London: Merlin.

Ahmed, N. (2012) 'Capitalism, covert action and state terrorism: toward a political economy of the dual state', in E. Wilson (ed.) The Dual State: Parapolitics, Carl Schmitt and the National Security Complex, Farnham: Ashgate.

Ahmed, N. (2013) 'Pentagon bracing for public dissent over climate and energy shocks: NSA Prism is motivated in part by fears that environmentally-linked disasters could spur anti-government activism', www.theguardian.com/environment/ea rth-insight/14-06-2013.

Ahrari, E.M. (2011) The Great Powers and the Hegemon, Basingstoke: Palgrave Macmillan. 
Ahrne, G. and Brunsson, N. (2006) 'Organizing the world', in M. Djelic and K. Sahlin-Andersson (eds) Transnational Governance: Institutional Dynamics of Regulation, Cambridge: Cambridge University Press.

Aidi, H.D. (2009) Redeploying the State: Corporatism, Neoliberalism and Coalition Politics, Basingstoke: Palgrave Macmillan.

Albo, G. (2004) 'Old and new economics of imperialism', in L. Panitch and C. Leys (eds) The New Imperial Challenge: Socialist Register 2004, London: Merlin.

Albo, G., Gindin, S. and Panitch, L. (2010) In and Out of Crisis: The Global Financial Meltdown and Left Alternatives, Oakland, CA: PM Press.

Albritton, R. (2002) 'Marx's value theory and subjectivity', www.area3.org.es.

Albritton, R. (2003) 'Superseding Lukács: a contribution to the theory of subjectivity', in R. Albritton and J. Simoulidis (eds) New Dialectics and Political Economy, Basingstoke: Palgrave Macmillan.

Albritton, R. (2004) 'Theorizing capital's deep structure and the transformation of capitalism', Historical Materialism, 12, 3: 73-92.

Alden, C., Morphet, S. and Vieira, M.A. (2010) The South in World Politics, Basingstoke: Palgrave Macmillan.

Alexandroff, A.S. (2010) 'Challenges in global governance: opportunities for G-x leadership', Policy Analysis Brief March 2010, Iowa: Stanley Foundation.

Al Faisal, T. (2013) 'Saudi Arabia's foreign policy', Middle East Policy, 20, 4: 37-44.

Al Mukhaini, A.A. (2014) 'Gulf states should form regional bloc with Iran', www.al-m onitor.com/pulse/originals/2014/04.

Al Tamimi, N.M. (2014) China-Saudi Arabia Relations: Marriage of Convenience or Strategic Alliance? London: Routledge.

Althusser, L. (1969) For Marx, English trans., London: Allen Lane.

Altvater, E. (1972) 'Zu einigen Problemen des Staatsinterventionsismus', PROKLA, 3: $1-54$.

Altvater, E. and Hoffmann, J. (1990) 'The West German state derivation debate: the relation between economy and politics as a problem of Marxist state theory', Social Text, 24: 134-155.

Amariglio, J. and Calliari, A. (1993) 'Marxian value theory and the problem of the subject: the role of commodity fetishism', in E. Apter and W. Pietz (eds) Fetishism as Cultural Discourse, Ithaca: Cornell University Press.

Amato, M. and Fantacci, L. (2012) The End of Finance, English trans., Cambridge: Polity.

Ambrosio, T. (2005) Challenging America's Global Preeminence: Russia's Quest for Multipolarity, Aldershot: Ashgate.

Ambrosio, T. (2008) 'Catching the "Shanghai Spirit": how the Shanghai Cooperation Organization promotes authoritarian norms in Central Asia', Europe-Asia Studies, 60, 8: 1321-1344.

Amin, S. (1976) Unequal Development: An Essay on the Social Formations of Peripheral Capitalism, New York: Monthly Review Press.

Amin, S. (1997) Capitalism in the Age of Globalization, London: Zed.

Amin, S. (2011) 'Exiting the crisis of capitalism or capitalism in crisis', in B.K. Gills (ed.) Globalization in Crisis, London: Routledge.

Amsden, A.H. (2001) The Rise of the Rest: Challenges to the West from Late Industrializing Economies, Cambridge, MA: Harvard University Press.

Anderson, J. (2008) 'The sovereign foundations transatlantic crisis in the post-9/11 era', in J. Anderson, G.J. Ikenberry and T. Risse (eds) The End of the West? Crisis and Change in the Atlantic Order, Ithaca: Cornell University Press. 


\section{Bibliography}

Andreski, S. (1968) Military Organization and Society, London: Routledge \& Kegan Paul. Andrews, D.M. (2006) 'Monetary power and monetary statecraft', in D.M. Andrews (ed.) International Monetary Power, Ithaca: Cornell University Press.

Angeloni, I. (2012) 'The Group of 20: trials of global governance in times of crisis', in B. Eichengreen and B. Park (eds) The World Economy after the Global Crisis: A New Economic Order for the 21st Century, Singapore: World Scientific.

Anghie, A. (2004) Imperialism, Sovereignty and the Making of International Law, Cambridge: Cambridge University Press.

Apeldoorn, B. (2014) 'Geopolitical strategy and class hegemony: towards a historicalmaterialist analysis', Spectrum Journal of Global Studies, 6, 1: 1-20.

Apeldoorn, B., De Graff, N. and Overbeek, H. (2012) 'The rebound of the capitalist state: the rearticulation of the state-capital nexus in the global crisis', Globalizations, 9, 4: 467-470.

Appadurai, A. (1990) 'Disjuncture and difference in the global cultural economy', in M. Featherstone (ed.) Global Culture: Nationalism, Globalization and Modernity, London: Sage.

Archibugi, D. (2003) 'Cosmopolitical democracy', in D. Archibugi (ed.) Debating Cosmopolitics, London: Verso.

Archibugi, D. (2004) 'Cosmopolitan democracy and its critics: a review', European Journal of International Relations, 10, 3: 937-973.

Archibugi, D. (2008) The Global Commonwealth of Citizens, Princeton: Princeton University Press.

Arendt, H. (1958) The Human Condition, Chicago: University of Chicago Press.

Arestis, P. and Karakitsos, E. (2013) Financial Stability and the Aftermath of the 'Great Recession', Basingstoke: Palgrave Macmillan.

Aris, S. (2011) Eurasian Regionalism: The Shanghai Cooperation Organization, Basingstoke: Palgrave Macmillan.

Arita, T. and McCann, P. (2000) 'Industrial alliances, and firm location behaviour: some evidence from the US semiconductor industry', Applied Economics, 32: 13911403.

Armijo, L.E. and Katada, S.N. (2013) 'Theorizing the financial statecraft of emerging powers', New Political Economy, www.tandfonline.com/doi/full/10.1080/13563467. 2013.866082\#.U0aL-stOXiw.

Armijo, L.E. and Katada, S.N. (2014) 'Multipolarity, financial statecraft and the liberal world order', www.isn.ethz.ch.

Armstrong, S. (2013) 'Will Asian trade strategies unite or divide', www.eastasiaforum. org/2013/09/15.

Arnsperger, C. (2008) Critical Political Economy: Complexity, Rationality and the Logic of Post-Orthodox Pluralism, London: Routledge.

Arrighi, G. (1994) The Long Twentieth Century. Money, Power and the Origins of our Times, English trans., London: Verso.

Arrighi, G. (2007) Adam Smith in Beijing: Lineages of the Twenty-First Century, London: Verso.

Arrighi, G., Barr, K. and Hisaeda, S. (1999a) 'The transformation of business enterprise', in G. Arrighi and B.J. Silver (eds) Chaos and Governance in the Modern World System, Minneapolis: University of Minnesota Press.

Arrighi, G., Hui, P.-K., Ray, K. and Reifer, T.E. (1999b) 'Geopolitics and high finance', in G. Arrighi and B.J. Silver (eds) Chaos and Governance in the Modern World System, Minneapolis: University of Minnesota Press. 
Arthur, C. (2001) 'Value, Labour and Negativity', Capital \& Class, 25: 15-39.

Arthur, C. (2002) The New Dialectic and Marx's Capital, Leiden: Brill.

Arthur, C. (2004) 'Subject and counter-subject', Historical Materialism, 12, 3: 93-102.

Arthur, C. (2006) 'The problem of use-value for a dialectic of capital', in R. Albritton and J. Simoulidis (eds) New Dialectics and Political Economy, Basingstoke: Palgrave Macmillan.

Aslam, W. (2013) The United States and Great Power Responsibility in International Society, London: Routledge.

Asser, M. (2000) 'ECHELON: big brother without a cause', news.bbc.co.uk/1/hi/ world/ europe/820758.stm.

Atkins, R. (2014) 'Emerging markets increasingly unstable amid US Fed taper fallout: wobbles spread across Argentina, developing Asia, Turkey and Brazil', www.ft.com/ 03-04-2014.

Avgouleas, E. (2012) Governance of Global Financial Market: The Law, the Economics, the Politics, Cambridge: Cambridge University Press.

Avineri, S. (1977) 'Trotsky, Marxism and the revolution of backwardness', in S. Avineri (ed.) Varieties of Marxism, The Hague: Martinus Nijhoff.

Bacevich, A.J. (2008) The Limits of Power: The End of American Exceptionalism, New York: Metropolitan Books.

Bache, I. and Flinders, M. (2004) 'Multi-level governance and British politics', in I. Bache and M. Flinders (eds) Multi-Level Governance, Oxford: Oxford University Press.

Bachmann, (2005) 'The German sustainability policy: state of the art', www.nachha ltigkeitsrat.de/uploads/media.

Bachrach, P. and Baratz, M.S. (1970) Power and Poverty, Oxford: Oxford University Press.

Bain \& Company (2012) 'A world awash with money: global trends through 2020', www.bain.com/images/bain_report.

Bakan, J. (2002) The Corporation: The Pathological Pursuit of Profit and Power, London: Constable.

Bamford, J. (2008) The Shadow Factory: The Ultra-Secret NSA from 9/11 to the Eavesdropping on America, New York: Random House.

Ban, C. (2013) 'Brazil's liberal neo-developmentalism: new paradigm or edited orthodoxy', Review of International Political Economy, 20, 2: 298-331.

Ban, C. and Blyth, M. (2011) 'The BRICS and the Washington consensus: an introduction', Review of International Political Economy, 20, 2: 241-255.

Banerjee-Guha, S. (2010) 'Introduction: transformative cities in the new global order', in S. Banerjee-Guha (ed.) Accumulation by Dispossession: Transformative Cities in the New Global Order, New Delhi: Sage.

Baran, P. (1973 [1957]) The Political Economy of Growth, London: Penguin.

Baran, P. and Sweezy, D. (1966) State Monopoly Capitalism, New York: Monthly Review Press.

Barkan, J. (2009) 'Use beyond value: Giorgio Agamben and a critique of capitalism', Rethinking Marxism, 21, 2: 243-259.

Barkan, J. (2013) Corporate Sovereignty: Law and Government under Capitalism, Minneapolis, MN: University of Minnesota Press.

Barrow, C. (2005) 'The return of the state: globalization, state theory and the new imperialism', New Political Science, 27, 2: 123-145.

Bauman, Z. (2002) Society under Siege, Cambridge: Polity. 


\section{Bibliography}

Baun, M. (2014) 'Transatlantic relations in a changing world: towards a more equal and effective partnership', in S. Roy, D. Cooper and B.M. Murphy (eds) Transatlantic Relations and Modern Diplomacy: An Interdisciplinary Examination, London: Routledge.

Beausang, F. (2012) Globalization and the BRICs: Why the BRICs will not Rule the World for Long, Basingstoke: Palgrave Macmillan.

Beck, U. (2012) Das deutsche Europa: Neue Machtlandschaften im Zeichen der Krise, Frankfurt: Suhrkamp.

Bedirhanoğlu, P. (2008) 'The state in neoliberal globalization: the merits and limits of Coxian conceptions', in A. Ayers (ed.) Gramsci, Political Economy and International Relations Theory, Basingstoke: Palgrave Macmillan.

Bell, J.R. (2003) 'From Hegel to Marx to the dialectic of capital', in R. Albritton and J. Simoulidis (eds) New Dialectics and Political Economy, Basingstoke: Palgrave Macmillan.

Bello, W. (2009) The Food Wars, London: Verso.

Bello, W. (2013) Capitalism's Last Stand? Deglobalization and the Age of Austerity, London: Zed.

Berberoglu, B. (2005) Globalization and Change: The Transformation of Global Capitalism, Lanham: Lexington.

Berglof, E. (2012) 'Filling the gaps - the Vienna Initiative and the role of international financial institutions in crisis management and resolution', in F. Allen, M. Aoki, N. Kiyotaki, R. Gordon, J.E. Stiglitz, J.-P. Fitoussi (eds) The Global Macro Economy and Finance, Basingstoke: Palgrave Macmillan.

Berle, A.A. and Means, G.C. (1933) The Modern Corporation and Private Property, New York: Macmillan.

Berman, M. (2011) Why America Failed: The Roots of Imperial Decline, New York: Wiley.

Bertoni, F., Elia, S. and Rabbiosi, L. (2013) 'Outward FDI from the BRICS: trends and patterns of acquisitions in advanced countries', in M.A. Marinov and S.T. Marinova (eds) Emerging Economies and Firms in the Global Crisis, Basingstoke: Palgrave Macmillan.

Bhattacharyya, S.B. (2011) 'The BRICs and Africa: emerging markets and SouthSouth cooperation', in R. Modi (ed.) South-South Cooperation: Africa on the Centre Stage, Basingstoke: Palgrave Macmillan.

Biancheri, F. (2010) The World Crisis: The Path to the World Afterwards, Paris: LEAP 2020.

Bieler, A. and Morton, A.D. (eds) (2006) Images of Gramsci: Connections and Contentions in Political Theory and International Relations, London: Routledge.

Biersteker, T.J. and Weber, C. (1996) 'The social construction of state sovereignty', in T.J. Biersteker and C. Weber (eds) State Sovereignty as Social Construct, Cambridge: Cambridge University Press.

Birch, K. and Tickell, A. (2010) 'Making neoliberal order in the United States', in K. Birch and V. Mykhnenko (eds) The Rise and Fall of Neoliberalism: Collapse of an Economic Order? London: Zed.

Biscop, S. and Renard, T. (2010) 'The European Union as a security actor: cooperative multilateralism', Security and Human Rights, 21, 1: 12-17.

Bjola, C. and Kornprobst, M. (2011) 'Introduction: the argumentative deontology of global governance', in C. Bjola and M. Kornprobst (eds) Arguing Global Governance, London: Routledge. 
Blair, D. (2014) 'Qatar and Saudi Arabia have ignited time bomb by funding global spread of radical Islam', www.telegraph.co.uk/news/worldnews/middleeast/iraq/ 04-10-2014.

Blake, M. (2013) 'We are all cosmopolitans now', in G. Brock (ed.) Cosmopolitanism versus Non-Cosmopolitanism, Oxford: Clarendon Press.

Blakely, R. (2009) State Terrorism and Neoliberalism: The North in the South, London: Routledge.

Blankert, J.W. (2012) 'ASEAN and the EU: natural partners', in D. Novotny and C. Portela (eds) EU-ASEAN Relations in the 21st Century, Basingstoke: Palgrave Macmillan.

Bloch, E. (1959 [1995]) The Principle of Hope, 3 vols, English trans., Harvard: MIT Press.

Blumberg, B. and Nogales, P. (2008) 'Marx after Marxism: an interview with Moishe Postone', platypus1917.org/01-03-2008.

Bobrow, D.B. (2008) 'Strategies beyond followership', in D.S. Bobrow (ed.) Hegemony Constrained: Evasion, Modification, and Resistance to American Foreign Policy, Pittsburg: University of Pittsburg Press.

Bodie, M.T. (2012) 'The post-revolutionary period in corporate law: returning to the theory to the firm', Seattle University Law Review, 335, 4: 1033-1059.

Boggs, C. (2011a) Phantom Democracy: Corporate Interests and Political Power in America, Basingstoke: Palgrave Macmillan.

Boggs, C. (2011b) Empire versus Democracy: The Triumph of Corporate and Military Power, London: Routledge.

Bohle, D. (2006) 'Neoliberal hegemony, transnational capital and the terms of the EU's eastward expansion', Capital \& Class, 30: 57-86.

Bohler, D. and Neunhöffer, G. (2006) 'Why is there no third way? The role of neoliberal ideology, networks and think tanks in combating market socialism and shaping transformation in Poland', in D. Plehwe, B. Walpen and G. Neunhöffer (eds) Neoliberal Hegemony: A Global Critique, London: Routledge.

Bond, P. (2007) 'Volatile, uneven and combined capitalism', in R. Albritton, B. Jessop and R. Westra (eds) Political Economy and Global Capitalism, London: Anthem.

Bone, J.D. (2010) 'Irrational capitalism: the social map, neoliberalism and the demodernization of the West', Critical Sociology, 36, 5: 717-740.

Bonefeld, W. (2013) 'Adam Smith and ordoliberalism: on the political form of market liberty', Review of International Studies, 39, 2: 233-250.

Boot, M. et al. (2013) 'Political warfare', Council on Foreign Relations Policy Innovation Memorandum No. 33, www.cfr.org/wars-and-warfare/political-warfare/p30894.

Boyapati, V. (2011) 'The politics of deflation', www.marketoracle.co.uk/Article25706. html.

Boyer, R. (2000) 'Is a finance-led growth regime a viable alternative to Fordism? A preliminary analysis', Economy and Society, 29, 1: 111-145.

Boyer, R., Uemura, H. and Isogai, A. (2012) 'Introduction: Asia, a social laboratory of contemporary capitalisms?' in R. Boyer, H. Uemura and A. Isogai (eds) Diversity and Transformations of Asian Capitalisms, London: Routledge.

Boyes, R. (2014) 'Putin's alliance threatens the globe: Russia, China and India together would have huge strength in military muscle and energy', www.thetimes.co.uk/ comment/28-05-2014.

Boyle, N. (2010) 2014: How to Survive the Next World Crisis, London: Continuum.

Bréard, B.F.G. and Blancas, P. (2014) 'Latin America regional outlook', Scotiabank Global Economics, March, www.gbm.scotiabank.com/English/bns_econ/latin.pdf. 


\section{Bibliography}

Bremmer, I. (2012) Every Nation for Itself: Winners and Losers in a G-Zero World, London: Portfolio Penguin.

Brenner, R. (2002) The Boom and the Bubble, London: Verso.

Brenner, R. (2006) The Economics of Global Turbulence: The Advanced Capitalist Economies from Long Boom to Long Downturn 1945-2005, London: Verso.

Brenner, R. (2009) 'The economy in a world of trouble [interview with Seong-Jin Jeong]', www.internationalviewpoint.org/spip.php?article1657.

Brenner, N. (2011) 'The space of the world: beyond state-centrism', in D. Palumbo-Liu et al. (eds) Wallerstein and the Problem of the World, Durham: Duke University Press.

Brenner, R. and Jeong, S. (2009) 'Overproduction not financial collapse is the heart of the crisis: the US, East Asia and the World', Asia-Pacific Journal, 6 May, www.japa nfocus.org/-Robert-Brenner/3043.

Breslin, S. (2012) 'East Asia and the global/transatlantic/western crisis', in S. Breslin (ed.) East Asia and the Global Crisis, London: Routledge.

Bretherton, C. and Vogler, J. (1999) The European Union as a Global Actor, London: Routledge.

Bricmont, J. (2006) Humanitarian Imperialism: Using Human Rights to Sell War, New York: Monthly Review Press.

Brittan, S. (1988) The Economic Consequences of Democracy, second edn, Aldershot: Wildwood House.

Broadman, H.G. (2007) Africa's Silk Road: China and India's New Economic Frontier, Washington: World Bank.

Brodwin, D. (2013) 'Suffering under the weight of inequality', www.usnews.com/op inion/blogs/economic-intelligence/2013/09/12.

Bromley, S. (2003) 'Reflections on empire, imperialism and the United States', Historical Materialism, 11, 3: 17-68.

Bromwich, D. (2003) 'The meaning of shock and awe', www.huffingtonpost.com/ 03-09-2013.

Brooker, P. (2010) Modern Stateless Warfare, Basingstoke: Palgrave Macmillan.

Brown, E.H. (2010) Web of Debt, Chippenham: Third Millennium.

Brown, E.H. (2013) 'The leveraged buyout of America', www.globalresearch.ca/ 5346992.

Brown, R.H. (2005) Culture, Capital and Democracy in the New America, New Haven: Yale University Press.

Brown, W. (2006) 'American nightmare: neoliberalism, neoconservatism and de-democratization', Political Theory, 34, 6: 690-714.

Bruno, K. and Karliner, J. (2002) Earthsummit.biz: The Corporate Takeover of Sustainable Development, Oakland: Food First Books.

Brusse, W. (2009) The Great Depression of Debt, New Jersey: Wiley.

Bryan, D. (2012) 'Going forward: the perpetual crisis of finance', Culture and Organization, 18, 2: 171-176.

Bryan, D. and Rafferty, M. (2006) Capitalism with Derivatives: A Political Economy of Financial Derivatives, Capital and Class, Basingstoke: Palgrave Macmillan.

Brzezinski, Z. (1997) The Grand Chessboard: American Primacy and its Geostrategic Imperatives, New York: Basic Books.

Brzezinski, Z. (2012) Strategic Vision: America and the Crisis of Global Power, New York: Basic Books.

Buck, P.D. (2008) 'Keeping the collaborators on board as the ship sinks: toward a theory of fascism and the US "middle class", Rethinking Marxism, 20, 1: 68-90. 
Buchanan, K. and Keohane, R.O. (2006) The Legitimacy of Global Governance Institutions, Cambridge: Cambridge University Press.

Buckley, P.J. and Ghauri, P.N. (2004) 'Globalisation, economic geography and the strategy of multinational enterprises', Journal of International Business Studies, 35: 81-98.

Buckley, R.P. (2012) 'Reforming international financial governance', in K. Macdonald, S. Marshall and S. Pinto (eds) New Visions for Market Governance: Crisis and Renewal, London: Routledge.

Buck-Morss, S. (2007) 'Sovereign right and the global left', Rethinking Marxism, 19, 4: $432-451$.

Budd, A. (2013) Class, States and International Relations: A Critical Appraisal of Robert Cox and Neo-Gramscian Theory, London: Routledge.

Bukharin, N. (1972 [1917]) Imperialism and the World Economy, English trans., London: Merlin.

Bull, H. (1977) The Anarchical Society. A Study of Order in World Politics, Basingstoke: Palgrave Macmillan.

Bulmer, S. (2013) 'Germany and the eurozone crisis: between hegemony and domestic politics', SPERI conference on 'Austerity vs. Growth: Future of the European Political Economy', University of Sheffield, 1-3 July.

Bulmer, S. and Paterson, W.E. (2010) 'Germany and the European Union: from "tamed power" to normalized power?', International Affairs, 86, 5: 1051-1073.

Bunde, T. (2013) 'Has Germany become NATO's "lost nation”? Prospects for a reinvigorated German NATO policy', American Institute for Contemporary German Studies, 6 December, www.aicgs.org/publications.

Burman, S. (2007) The State of the American Empire: How the USA Shapes the World, London: Earthscan.

Burn, G. (2002) 'Germany unlocked? Globalising capital and the logic of accumulation', in J. P. Abbott and O. Worth (eds) Critical Perspectives on International Political Economy, Basingstoke: Palgrave Macmillan.

Burnham, J. (1941) The Managerial Revolution, London: John Day.

Burns, T.R. and Kamali, M. (2003) 'The evolution of parliaments: a comparativehistorical perspective on assemblies and political decision-making', in G. Delanty and E.F. Isin (eds) Handbook of Historical Sociology, London: Sage.

Burrage, M. (2008) Class Formation, Civil Society and the State, Basingstoke: Palgrave Macmillan.

Butler, J. (2012) The Golden Revolution: How to Prepare for the Coming Global Gold Standard, New York: Wiley.

Butler, T. and Savage, M. (eds) (1995) Social Change and the Middle Classes, London: UCL Press.

Butler, T. and Watt, P. (2007) Understanding Social Inequality, London: Sage.

Buzan, B. (2011) 'A world order without superpowers: decentred globalism', International Relations, 25, 1: 3-25.

Byrne, D. (1998) Complexity Theory and the Social Sciences: An Introduction, London: Routledge.

Cabrera, L. (2004) Political Theory of Global Justice: A Cosmopolitan Case for the World State, London: Routledge.

Callaghan, M. (2014) 'BRICS muscle up over Russia', www.lowyinterpreter.org/post/ 31-03-2014. 


\section{Bibliography}

Calleo, D.P. (2009) 'Twenty-first century geopolitics and the erosion of the dollar order', in E. Helleiner and J. Kirshner (eds) The Future of the Dollar, Ithaca: Cornell University Press.

Callinicos, A. (2002) 'Marxism and global governance', in D. Held and A. McGrew (eds) Governing Globalization, London: Polity Press.

Callinicos, A. (2005) 'Imperialism and global political economy', International Socialism, 108, www.isj.org.uk/?id=140.

Callinicos, A. (2007) 'Does capitalism need the state system?', Cambridge Review of International Affairs, 20, 4: 533-549.

Callinicos, A. (2009) Imperialism and Global Political Economy, Cambridge: Polity.

Capannelli, G. (2011) Institutions for economic and financial integration in Asia: trends and prospects, ADBI Working Paper 308, Tokyo: Asian Development Bank Institute, www.adbi.org.

Carchedi, G. (2001) 'Imperialist contradictions at the threshold of the third millennium: a new phase?', in R. Albritton, M. Itoh, R. Westra and A. Zuege (eds) Phases of Capitalist Development: Booms, Crises and Globalization, Basingstoke: Palgrave Macmillan.

Carmody, P. (2013) The Rise of the BRICS in Africa: The Geopolitics of South-South Relations, London: Zed.

Carroll, W.K. (2004) Corporate Power in a Globalizing World, Ontario: Oxford University Press.

Carroll, W.K. (2010) The Making of a Transnational Capitalist Class: Corporate Power in the 21st Century, London: Zed.

Carroll, W.K. and Carson, C. (2006) 'Neoliberalism, capitalist class formation and the global network of corporations and policy groups', in D. Plehwe, B. Walpen and G. Neunhöffer (eds) Neoliberal Hegemony: A Global Critique, London: Routledge.

Cartalucci, T. (2014) 'NATO hopes for a "Russian invasion" of Ukraine', www.globa lresearch.ca/15-07-2014.

Carver, T. (2000) 'Hegel and Marx: Reflections on the Narrative', in T. Burns and I. Fraser (eds) The Hegel-Marx Connection, Basingstoke: Palgrave.

Casarini, N. (2009) Remaking Global Order, Oxford: Oxford University Press.

Casey, T. (2011) 'Capitalism, crisis and a zombie named TINA', in T. Casey (ed.) The Legacy of the Crash: How the Financial Crisis Changed America and Britain, Basingstoke: Palgrave Macmillan.

Castañeda, J.G. (2006) 'Latin America’s left turn', Foreign Affairs, 85, 3: 28-43.

Centano, M.A. (2002) Blood and Debt: War and the Nation State in Latin America, Pennsylvania: Pennsylvania University Press.

Cerny, P.G. (1997) 'Paradoxes of the competition state: the dynamics of political globalization', Government and Opposition, 32, 2: 251-274.

Cerny, P.G. (2000) 'Restructuring the political arena: globalization and the paradoxes of the competition state', in R.D. Germain (ed.) Globalization and its Critics, Basingstoke: Macmillan.

Cerny, P.G. , Menz, G. and Soederberg, S. (2005) 'Different roads to globalization: neoliberalism, the competition state, and politics in a more open world', in S. Soederberg, G. Menz and P. Cerny (eds) Internalizing Globalization: The Rise of Neoliberalism and the Decline of National Varieties of Capitalism, Basingstoke: Palgrave Macmillan.

Chance, G. (2010) China and the Credit Crisis: The Emergence of a New World Order, Singapore: Wiley. 
Chandler, W.M. (1909) The World State, Johannesburg: Grocott \& Sherry.

Chandran, N. (2015) 'Is the dollar losing its clout among emerging markets?', www. cnbc/09-03-2015.

Chang, H.-J. (2014) 'This is no recovery, this is a bubble - and it will burst', www. theguardian/2014-02-24.

Chapple, S. (2012) 'Origins of transnational governance in the nineteenth century', in M. Head, S. Mann and S. Kozlina (eds) Transnational Governance: Emerging Models of Global Legal Regulation, Farnham: Ashgate.

Charlton, A. (2008) 'Capital market liberalization and poverty', in J.A. Ocampo and J.E. Stiglitz (eds) Capital Market Liberalization and Development, Oxford: Oxford: University Press.

Chase-Dunn, C. (1981) 'Inter-state system and capitalist world-economy: one logic or two?', International Studies Quarterly, 25, 1: 19-42.

Chase-Dunn, C. (1989) Global Formation: Structures of the World Economy, Cambridge: Basil Blackwell.

Chayes, A. and Chayes, A.H. (1995) The New Sovereignty: Compliance with New International Regulatory Agreements, Cambridge, MA: Harvard University Press.

Chaziza (2013) 'The Arab Spring and the implications for Chinese policy', www. rubincenter.org/wp-content/uploads/08-2013.

Cheru, F. (2011) 'South-South cooperation: what prospects for a new Bandung consensus?', in R. Modi (ed.) South-South Cooperation: Africa on the Centre Stage, Basingstoke: Palgrave Macmillan.

Chossudovsky, M. (2013) "The confiscation of bank savings to "save the banks", www.globalresearch.ca/5329411.

Chryssochoou, D.N. (2009) Theorizing European Integration, second edn, London: Routledge, 131.

Chulov, M. (2014) 'Is America's relationship with Saudi Arabia broken beyond repair?' The Guardian, 28 March, www.theguardian.com/world/2014/mar/28/bara ck-obama-saudi.

Chun, K.H. (2013) The BRICS Superpower Challenge: Foreign and Security Policy Analysis, Farnham: Ashgate.

Chwieroth, J.M. (2010) The IMF and the Rise of Financial Liberalization, Princeton: Princeton University Press.

Ciro, T. (2012) The Global Financial Crisis: Triggers, Responses and Aftermath, Farnham: Ashgate.

Clackson, A. (2014) 'Strategic alliance between Russia and China: Shanghai Cooperation Organisation on the rise', www.globalresearch.ca/5402861.

Clark, I. (2011) Hegemony in International Society, Oxford: Oxford University Press.

Clarke, S. (1989) 'The Marxist theory of overaccumulation and crisis', www.warwick. ac.uk/ syrbe/pubs/sands.pdf.

Clarke, S. (1992) 'The global accumulation of capital and the periodisation of the capitalist state form', in W. Bonefeld et al. (eds) Open Marxism Volume 1: Dialectics and History, London: Pluto.

Clarke, S. (1994) Marx's Theory of Crisis, Basingstoke: Macmillan Press.

Clarke, S. (2001) 'Class struggle and the global overaccumulation of capital', in R. Albritton, M. Itoh, R. Westra and A. Zuege (eds) Phases of Capitalist Development: Booms, Crises and Globalization, Basingstoke: Palgrave Macmillan.

Clarke, S. (2005) 'The neoliberal theory of society', in A. Saad-Filho and D. Johnstone (eds) Neoliberalism: A Critical Reader, London: Pluto. 


\section{Bibliography}

Cleaver, T. (2013) Understanding the World Economy, fourth edn, London: Routledge. Coase, R. (1937) 'The theory of the firm', Economica, 4, 16: 304-405.

Coen, D. and Grant, W. (2001) 'Corporate political strategy and global policy: a case study of the transatlantic business dialogue', European Business Journal, 13, 1: 37-44.

Cohan, P.S. and Rangan, U. (2010) Capital Rising: How Capital Flows are Changing Business Systems All over the World, Basingstoke: Palgrave Macmillan.

Cohen, B.J. (2008) International Political Economy: An Intellectual History, Princeton: Princeton University Press.

Cohen, B.J. (2010) 'The international monetary system: diffusion and ambiguity', in P.F. Diehl and B. Frederking (eds) The Politics of Global Governance: International Organizations in an Interdependent World, Boulder: Rienner.

Cohen, J. (2004) 'Whose sovereignty? Empire versus international law', Ethics and International Affairs, 18, 3: 1-24.

Cohen, R. and Kennedy, B.J. (2000) Global Sociology, Basingstoke: Palgrave Macmillan.

Cohen, S. (2008) Geopolitics: The Geography of International Relations, Lanham: Rowman \& Littlefield.

Cohen-Tanugi, L. (2003) An Alliance at Risk: The United States and Europe since September 11, English trans., Baltimore: The Johns Hopkins University Press.

Cohen-Tanugi, L. (2008) The Shape of the World to Come: Charting the Geopolitics of a New Century, English trans., New York: Columbia University Press.

Collins, J.L., Di Leonardo, M. and Williams, B. (eds) (2008) New Landscapes of Inequality and the Erosion of Democracy in America, Santa Fe: School for Advanced Research Press.

Cooke, S. (2013) 'Is capitalism to blame for the Syrian war drive?', www.counterp unch.org/2013/09/18.

Cooley, J.K. (2008) Currency Wars: Forging Money to Break Economies, London: Constable.

Copley, G.R. (2014) 'Decline of the West: seven strategic ramifications of Crimea's return to Russia', www.worldtribune.com/2014/03/17.

Coppola, F. (2014) 'Capital controls or cooperation?', www.pieria.co.uk/articles.

Cornia, G.A. (2014) 'Recent distributive changes in Latin America: an overview', in G.A. Cornia (ed.) Falling Inequality in Latin America: Policy Changes and Lessons, Oxford: Oxford University Press.

Cowling, K. and Tomlinson, P. (2005) 'Globalisation and corporate power', Contributions to Political Economy, 24: 33-54.

Cox, R.W. (1996 [1983]) 'Gramsci, hegemony and international relations: an essay in method', reprinted in R.W. Cox, Approaches to World Order, Cambridge: Cambridge University Press.

Cox, R.W. (1999) 'Civil society at the turn of the millennium: prospects for an alternative world order', Review of International Studies, 25, 1: 3-28.

Cox, R.W. (2012) 'Corporate finance and US foreign policy', in R.W. Cox (ed.) Corporate Power and Globalization in US Foreign Policy, London: Routledge.

Cox, R.W. (2013) 'Transnational capital and the politics of global supply chains', Class, Race and Corporate Power, 1, 1: 1-28.

Cox, R.W. and Lee, S. (2012) 'Transnational capital and the US-China nexus', in R.W. Cox (ed.) Corporate Power and Globalization in US Foreign Policy, London: Routledge.

Crane, A., Matten, D. and Moon, J. (2008) Corporations and Citizenship, Cambridge: Cambridge University Press. 
Cribb, R. (2009) 'Introduction: parapolitics, shadow governance and criminal sovereignty', in E. Wilson (ed.) Government of the Shadows: Parapolitics and Criminal Sovereignty, London: Pluto.

Crouch, C. (2011) The Strange Non-Death of Neoliberalism, Cambridge: Polity.

Cumberworth, M.B. (1996) 'Theory of exclusive trading blocs', Working Papers in Economics, 239, University of Sydney, Department of Economics.

Cutler, C. (2005) 'Gramsci, law and the culture of global capitalism', International Review of Social and Political Philosophy, 8, 4: 527-542.

Cutler, C. (2011) 'The privatization of political authority in the global political economy', in G. Teeple and S. McBride (eds) Relations of Global Power: Neoliberal Order and Disorder, Toronto: University of Toronto Press.

Cynamon, B.Z. (2013) 'Understanding the great recession', in B.Z. Cynamon, S. Fazzari and M. Setterfield (eds) After the Great Recession, Cambridge: Cambridge University Press.

Dabène, O. (2009) The Politics of Regional Integration in Latin America: Theoretical and Comparative Explorations, Basingstoke: Palgrave Macmillan.

Dahbour, O. (2003) Illusion of the Peoples. A Critique of National Self-Determination, Lanham: Lexington.

Dalby, S. (2013) 'Challenging cartographies of enmity', in J. Stavrianakis and J. Selby (eds) Militarism and International Relations: Political Economy, Security, Theory, London: Routledge.

Daley, J. (2009) 'There'll be nowhere to run from the new world government', The Telegraph, 19 December, www.telegraph.co.uk/comment/columnists/janetdaley/6845967.

Dallmayr, F. (2010) The Promise of Democracy: Political Agency and Transformation, Albany: SUNY Press.

Daniels, P.W., Ho, K.C. and Hutton, T.A. (eds) (2012) New Economic Spaces in Asian Cities: From Industrial Restructuring to the Cultural Turn, London: Routledge.

Dannreuther, R. (2013) International Security: The Contemporary Agenda, Cambridge: Polity.

Daping, H. (2012) 'Have a concrete and historic understanding of globalization and what China has done', in C. Tuo (ed.) Chinese Perspectives on Globalization and Autonomy, Leiden: Brill.

Davenport, A. (2011) At the Limit: On Realism, Materialism and International Theory, $\mathrm{PhD}$ thesis, Brighton: University of Sussex.

Davidson, L. (2014) 'America your days as a superpower are numbered', www.telegrap h.co.uk/finance/economics/12-09-2014.

Davies, R.W. (2012) The Era of Global Transition, Basingstoke: Palgrave Macmillan.

Davies, W. (2011) 'From new times to end times', New Statesman, 21 November: 31-33.

Davis, A.E. (2010a) 'Marx and the mixed economy', Science and Society, 74, 3: 409-428.

Davis, L.E. and Huttenback, R.A. (1986) Mammon and the Pursuit of Empire: The Political Economy of British Imperialism 1860-1912, Cambridge: Cambridge University Press.

Davis, P.R. (2010b) 'America's middle class in crisis', www.marketoracle.co.uk/Arti cle21732.html.

Dean, J. (2009) Democracy and other Neoliberal Fantasies. Communicative Capitalism and Left Politics, Durham, NC: Duke University Press.

Dean, K. (2003) Capitalism and Citizenship. The Impossible Partnership, London: Routledge.

Dean, M. (2014) 'Rethinking neoliberalism', Journal of Sociology, 50, 2. 


\section{Bibliography}

Deardorff, A.V. and Stern, R.M. (1994) 'Multilateral trade negotiations and preferential trading arrangements', in A.V. Deardorff and R.M. Stern (eds) Analytical and Negotiating Issues in the Global Trading System, Ann Arbor: University of Michigan Press.

De Angelis, M. (1996) 'Social relations, commodity fetishism and Marx's critique of political economy', Review of Radical Political Economics, 28, 4: 1-29.

De Angelis, M. (2010) 'The production of the commons and the "explosion" of the middle class', Antipode, 42, 4: 954-977.

Debord, G. (1994) The Society of the Spectacle, English trans., New York: Zone Books.

Dejung, C. and Petersson, N.P. (2013) 'Power, institutions, and global markets: actors, mechanisms and foundations of worldwide economic integration 1850-1930', in C. Dejung and N.P. Petersson (eds) The Foundations of Worldwide Economic Integration, Cambridge: Cambridge University Press.

Delanty, G. (2000) Citizenship in a Global Age: Society, Culture, Politics, Buckingham: Open University Press.

Deleuze, G. and Guattari, F. (2004a [1977]) Anti-Oedipus: Capitalism and Schizophrenia Vol. I, English trans., London: Continuum.

Deleuze, G. and Guattari, F. (2004b [1980]) A Thousand Plateaus. Capitalism and Schizophrenia Vol. II, English trans., London: Continuum.

Deneault, A. (2010) Offshore: Tax Havens and the Rule of Global Crime, English trans., New York: New Press.

Derviş, K. (2012) 'World economy: convergence, divergence and interdependence', www.imf.org/09-2012.

Desai, A. (2013) 'The BRICs are building a challenge to western economic supremacy: Brazil, Russia, India, China and South Africa, united by rejection of the neoliberal model, plan to create their own institutions', www.theguardian.com/commentisfree/ 2013/apr/02.

Desai, R. (2006) 'Neoliberalism and cultural nationalism', in D. Plehwe, B. Walpen and G. Neunhöffer (eds) Neoliberal Hegemony: A Global Critique, London: Routledge.

D'Estaing, O.G. (2007) 'The needs and challenges of global governance', in M. Fratianni, P. Savona and J.J. Kirton (eds) Corporate, Public and Global Governance: The G8 Contribution, Aldershot: Ashgate.

Devereux, M.B. and Yetman, J. (2011) 'Financial contagion and vulnerability of Asian financial markets', in M.B. Devereux, P.R. Lane, C.-Y. Park and S.-J. Wei (eds) The Dynamics of Asian Financial Integration, London: Routledge.

Devine, F. (2005) 'Middle class identities in the United States', in F. Devine, M. Savage and J. Scott (eds) Rethinking Class. Culture, Identities and Lifestyles, Basingstoke: Palgrave Macmillan.

Devine, F. and Savage, M. (2005) 'The Cultural Turn, Sociology and Class Analysis', in F. Devine, M. Savage and J. Scott (eds) Rethinking Class. Culture, Identities and Lifestyles, Basingstoke: Palgrave Macmillan.

Dierckxsens, W. (2000) The Limits of Capitalism: An Approach to Globalization without Neoliberalism, English trans., London: Zed.

Di Leonardo, M. (2008) 'Introduction: new global and American landscapes of inequality', in J.L. Collins, M. Di Leonardo and B. Williams (eds) New Landscapes of Inequality, Santa Fe: School for Advanced Research Press.

Di Maggio, P. and Powell, W. (1987) 'The iron cage revisited: institutional isomorphism and collective rationality in organizational fields', American Sociological Review, 48, 2: $147-160$. 
Dirlik, A. (2001) Global Modernity: Modernity in the Age of Global Capitalism, Boulder: Paradigm.

Dirlik, A. (2011) 'Revisioning modernity: modernity in Eurasian perspectives', Inter-Asia Cultural Studies, 12: 284-305.

Dixon, A. and Monk, H.B. (2010) 'Rethinking the sovereign in sovereign wealth fund', SSRN, ssrn.com.

Djelic, M.-L. and Sahlin-Andersson, K. (2006) Transnational Governance : Institutional Dynamics of Regulation, Cambridge: Cambridge University Press.

Djilas, M. (1957) The New Class: Analysis of the Communist System, English trans., London: Thames \& Hudson.

Domhoff, W. (2014) Who Rules America? The Triumph of the Corporate Rich, seventh edition, Columbus: McGraw-Hill.

Drezner, D.W. (2007) All Politics is Global: Explaining International Regulatory Regimes, Princeton: Princeton University Press.

Dugin, A. (2012) The Fourth Political Theory, English trans., London: Arktos.

Dugin, A. (2014) 'The war on Russia and its ideological dimension', openrevolt.info/ 2014/03/11.

Duménil, G. and Lévy, D. (2001) 'Periodizing capitalism: technology, institutions, relations of production', in R. Albritton, M. Itoh, R. Westra and A. Zuege (eds) Phases of Capitalist Development: Booms, Crises and Globalization, Basingstoke: Palgrave Macmillan.

Duncan, G. (1989) 'Introduction', in G. Duncan (ed.) Democracy and the Capitalist State, Cambridge: Cambridge University Press.

Dunt, I. (2014) 'Comment: The EU-US treaty which enforces privatisation', www.pol itics.co.uk/comment/2014/02/24.

Durden, T. (2014) 'The sanctions war: Washington threatens Russia over "petrodollarbusting deal"', www.globalresearch.ca.

Durham, M. and Power, M. (eds) (2010) New Perspectives on the Transnational Right, Basingstoke: Palgrave Macmillan.

Dussel-Peters, E. (2006) 'The Mexican economy since NAFTA: socioeconomic integration or disintegration?', in D. Plehwe, B. Walpen and G. Neunhöffer (eds) Neoliberal Hegemony: A Global Critique, London: Routledge.

Dzyubenko, O. (2014) 'US vacates base in Central Asia as Russia's clout rises', www. reuters.com/article/2014/06/03.

Eaves, J. (2011) 'Capital, absolute overaccumulation and the fascist state', pogoprincip le.wordpress.com/16-03-2011.

Ebner, A. (2011) 'Transnational markets and the Polanyi problem', in C. Joerges and J. Falke (eds) Karl Polanyi, Globalisation and the Potential of Law in International Markets, Oxford: Hart.

The Economist (2014) 'Worse than nothing: interest rates turn negative for some', www.economist.com/finance-and-economics/08-11-2014.

Ehret, M. (2012) 'Financial socialism: the role of financial economics in economic disorganization', econ.as.nyu.edu/docs/IO/27425/Ehret_11262012.pdf.

Ehteshami, A. (2007) Globalization and Geopolitics in the Middle East: Old Game, New Rules, London: Routledge.

Eichengreen, B. (2008) Globalizing Capital: A History of the International Monetary System, Princeton: Princeton University Press.

Eichengreen, B. (2011) Exorbitant Privilege: The Rise and Fall of the Dollar, Oxford: Oxford University Press. 


\section{Bibliography}

Elsner, W. (2012) 'Financial capitalism - at odds with democracy: the trap of an “impossible" profit rate', Real World Economics Review, 62: 132-159, www.paecon. net/PAEReview/issue62.

Emadi-Coffin, B. (2002) Rethinking International Organization: Deregulation and Global Governance, London: Routledge.

Engdahl, F.W. (2004) A Century of War. Anglo-American Oil Politics and the New World Order, London: Pluto.

Engdahl, F.W. (2009) Full Spectrum Dominance: Totalitarian Democracy in the New World Order, Edition Engdahl.

Escobar, P. (2015) 'What the BRICS plus Germany are really up to', http://rt.com/op -edge/236219-russia-china-germany-trade-axis/27-02-2015.

Eskelinen, H., Liikanen, I. and Scott, J.W. (2013) 'On the edge of neighbourhood: regional dimensions of the EU-Russia interface', in H. Eskelinen, I. Liikanen and J.W. Scott (eds) The EU-Russia Borderland: New Contexts for Regional Cooperation, London: Routledge.

Evans, L. (2011) 'Understanding the political economy of forced dependency in the globalized world', www.feasta.org.

Evans-Pritchard, A. (2013) 'Britain to have worst 2014 trade deficit in industrial world on EU forecasts', www.telegraph.co.uk/finance/economics/05-11-2013.

Evans-Pritchard, A. (2014a) 'The nagging fear that QE itself may be causing deflation', www.telegraph.co.uk/finance/comment/04-06-2014.

Evans-Pritchard, A. (2014b) 'World economy so damaged it may need permanent QE: Markets are realising that the five-and-a-half year recovery since the financial crisis may already be over', www.telegraph.co.uk/finance/economics/15-10-2014.

Evans-Pritchard, A. (2014c) 'One simple reason why global stock markets are reeling: The world's central banks have slashed stimulus by $\$ 125 \mathrm{bn}$ a month since the end of last year leading to the current market rout', www.telegraph.co.uk/finance/econom ics/16-10-2014.

Everling, C. (2010) Dialectics of Class Struggle in the Global Economy, London: Routledge.

Falk, R. (1995) On Humane Governance: Towards a New Global Politics, Philadelphia: Pennsylvania State University Press.

Falk, R. (2004) The Declining World Order: America's Imperial Geopolitics, London: Routledge.

Falk, R. (2012) 'Is there a new geopolitics? A new form of geopolitics is threatening to dethrone the old paradigm of a hard power, West-centric world', www.aljazeera. com/indepth/opinion/2012/08.

Fanta, E., Shaw, T.M. and Tang, V.T. (eds) (2013) Comparative Regionalisms for Development in the 21st Century, Farnham: Ashgate.

Faux, G.P. (2006) The Global Class War: How America's Bipartisan Elite Lost our Future, Chichester: Wiley.

Featherstone, K. (2003) 'Introduction: in the name of "Europe", in K. Featherstone and C.M. Radaelli (eds) The Politics of Europeanization, Oxford: Oxford University Press.

Fedorinova, J. et al. (2015) 'Russia picks new monetary policy chief as currency plummets', www.bloomberg.com/news/14-01-2015.

Feenberg, A. (1996) 'Review of Moishe Postone: Time, Labor, and Social Domination: A Reinterpretation of Marx's Critical Theory', Theory and Society, 25, 4: 607-611.

Feenberg, A. (2014) The Philosophy of Praxis: Marx, Lukács and the Frankfurt School, London: Verso. 
Feldstein, M. (2013) 'Resolving the global imbalance: the dollar and the US savings rate', in L. Yueh (ed.) China and Globalization: Critical Concepts in Economics, London: Routledge.

Fisher, R.D. (2008) China's Military Modernization: Building for Regional and Global Reach, Westport: Praeger.

Fitsanakis, J. (2008) 'German intelligence active in Kosovo', www.intelnews.org/ 29-11-2008.

Fleetwood, S. (2012) 'Laws and tendencies in Marxist political economy', Capital and Class, 36, 2: 235-262.

Flores-Macías, G.A. (2012) After Neoliberalism? The Left and Economic Reforms in Latin America, Oxford: Oxford University Press.

Foley, D.K. (2001 [1986]) 'Money, accumulation, crisis', in J. Lesbourne and H. Sonnenschein (ed.) Marxian Economics I, London: Routledge.

Foster, J.B. and Magdoff, H. (2009) The Great Financial Crisis: Causes and Consequences, New York: Monthly Review Press.

Fotopoulos, T. (2014) 'BRICS and the myth of a multipolar world', english.pravda.ru/ world/asia/06-10-2014.

Fouskas, V.K. (2003) Zones of Conflict: US Foreign Policy in the Balkans and Greater Middle East, London: Pluto.

Fouskas, V.K. and Dimoulas, C. (2013) Greece, Financialization and the EU: The Political Economy of Debt and Destruction, Basingstoke: Palgrave Macmillan.

Fouskas, V. and Gökay, B. (2005) The New American Imperialism: Bush's War on Terror and Blood for Oil, New York: Praeger.

Fouskas, V. and Gökay, B. (2012) The Fall of the US Order: Global Fault-Lines and the Shifting Imperial Order, London: Pluto.

Frank, A.G. (1971 [1969]) Capitalism and Underdevelopment in Latin America, London: Pelican.

Frank, T. (2002) One Market under God. Extreme Capitalism, Market Populism and the End of Economic Democracy, New York: Vintage.

Frankfurter Allgemeine Zeitung (2014) 'Gauck-Rede im Wortlaut: "Deutschland muss bereit sein, mehr zu tun"', www.faz.net/aktuell/politik/inland/31-01-2014.

Freeman, A. and Kagarlitsky, B. (2004) 'Introduction: world empire - or a world of empires', in A. Freeman and B. Kagarlitsky (eds) The Politics of Empire: Globalization in Crisis, London: Pluto.

Freeman, R. (2007) 'The challenge of the growing globalization of labor markets to economic and social policy', in E. Paus (ed.) Global Capitalism Unbound: Winners and Losers from Offshore Outsourcing, Basingstoke: Palgrave Macmillan.

Friedman, J. and Kraus, W. (2011) Engineering the Financial Crisis: Systemic Risk and the Failure of Regulation, Philadelphia: University of Pennsylvania Press.

Friedman, T.L. (1999) The Lexus and the Olive Tree, New York: Farrar, Strauss, Giroux.

Friedrichs, J. (2004) 'The neo-medieval Renaissance: global governance and international law in the new Middle Ages', in I.F. Dekker and W.G. Werner (eds) Governance and International Legal Theory, Leiden: Nijhoff.

Frisby, D. (1992) The Alienated Mind: The Sociology of Knowledge in Germany 19181933, London: Routledge.

Froud, J., Johal, S., Leaver, A. and Williams, K. (2006) Financialization and Strategy: Narrative and Numbers, London: Routledge.

Fuchs, C. (2010) 'Critical globalization studies and the new imperialism', Science and Society, 74, 2: 215-247. 


\section{Bibliography}

Futter, A. (2013) Ballistic Missile Defence and US National Security Policy: Normalization and Acceptance after the Cold War, London: Routledge.

Gaist, T. (2014) 'US military planning to suppress domestic unrest', www.wsws.org/ en/articles/2014/08/30.

Gallarotti, G.M. (2010) Cosmopolitan Power in International Relations: A Synthesis of Realism, Neoliberalism and Constructivism, Cambridge: Cambridge University Press.

Gamble, A. (2006) 'Two faces of neoliberalism', in R. Robinson (ed.) The Neoliberal Revolution: Forging the Market State, Basingstoke: Palgrave Macmillan.

Gamble, A. (2013) 'The EU and the evolving shift of power in global governance', in M. Telò and F. Ponjaert (eds) The EU's Foreign Policy: What Kind of Power and Diplomatic Action? Farnham: Ashgate.

Gammon, E. (2010) 'Oedipal authority and capitalist sovereignty: a Deleuzoguattarian reading of IR theory', Journal of International Relations and Development, 13, 4: 354-377.

Gamson, W.A. (2006) 'Movement impact on cultural change', in S. Pfohl, A. Van Wagenen, P. Arend, A. Brooks and D. Leckenby (eds) Culture, Power and History: Studies in Critical Sociology, Leiden: Brill.

Ganser, D. (2005) NATO's Secret Armies: Operation Gladio and Terrorism in Western Europe, New York: Frank Cass.

Ganser, D. (2012) "“America is addicted to oil". US secret warfare and dwindling oil reserves in the context of peak oil and 9/11', in E. Wilson (ed.) The Dual State: Parapolitics, Carl Schmitt and the National Security Complex, Farnham: Ashgate.

Garcia, C. (2013) 'The collapse of US infrastructure spending', ftalphaville.ft.com/ 30-10-2013.

Garnaut, R. (2013) 'Making the international system work for the platinum age', in D.S. Prasado Rao and B. van Ark (eds) World Economic Performance: Past, Present and Future, Cheltenham: Edward Elgar.

Garrison, R.W. (2000) Time and Money: The Macroeconomics of Capital Structure, London: Routledge.

Gause, F.G. (2011) Saudi Arabia in the New Middle East, Council Special Report No. 63, December, www.cfr.org/content/publications/attachments/Saudi_Arabia_CSR63.pdf.

Gawel, K. (2012) 'Value as subject: the unilateral capital relation', canononline.org.

Geisst, C.R. (2005) Undue Influence. How the Wall Street Elite put the Financial System at Risk, New Jersey: Wiley.

Gellner, E. (1983) Nations and Nationalism, Cambridge: Blackwell.

George, D.A.R. (1993) Economic Democracy: The Political Economy of Self-management and Participation, Basingstoke: Palgrave Macmillan.

George, S. (1988) A Fate Worse than Debt, New York: Grove Weidenfeld.

Germain, R. (2010) Global Politics and Financial Governance, Basingstoke: Palgrave Macmillan.

Germain, R. (2011) 'New Marxism and the problem of subjectivity: towards a critical and historical international political economy', in S. Shields, I. Bruff and H. Macartney (eds) Critical International Political Economy: Dialogue, Debate and Dissensus, Basingstoke: Palgrave Macmillan.

Gerschenkron, A. (1962) Economic Backwardness in Historical Perspective, Cambridge: Harvard University Press.

Gibbs, D.N. (2012) 'The military-industrial complex in a globalized context', in R.W. Cox (ed.) Corporate Power and Globalization in US Foreign Policy, London: Routledge. 
Giddens, A. (1984) The Constitution of Society, Cambridge: Polity.

Giddens, A. (1985) The Nation State and Violence, Cambridge: Polity.

Gilbert, A. (1999) Must Global Politics Constrain Democracy? Great-Power Realism, Democratic Peace and Democratic Internationalism, Princeton: Princeton University Press.

Gilbert, J. (2010) 'The loss of philosophy', www.redpepper.org.uk/The-loss-of-philosophy.

Gilens, M. and Page, B.I. (2014) 'Testing theories of American politics: elites, interest Groups, and average citizens', Perspectives on Politics, 12, 3: 564-581.

Giles, C. (2014) 'China poised to pass US as world's leading economic power this year', www.ft.com/30/04/2014.

Giles, C. and Harding, R. (2014) 'IMF warns on emerging market exposure to capital flight', www.ft.com/21-01-2014.

Gill, S. (1990) American Hegemony and the Trilateral Commission, Cambridge: Cambridge University Press.

Gill, S. (1993) 'Neoliberalism and the shift towards a US-centred transnational hegemony', in H. Overbeek (ed.) Restructuring Hegemony in the Global Political Economy: The Rise of Transnational Neoliberalism in the 1980s, London: Routledge.

Gill, S. (1998) 'New constitutionalism, democratization and global political economy', Pacifica Review, 10, 1: 23-38.

Gill, S. (2002) 'Globalization, market civilization and disciplinary liberalism', in E. Hovden and E. Keene (eds) The Globalization of Liberalism, Basingstoke: Palgrave Macmillan.

Gill, S. (2008) Power and Resistance in the New World Order, Basingstoke: Palgrave Macmillan.

Gill, S. and Law, D. (1988) The Global Political Economy, Baltimore: Johns Hopkins.

Gill, S. and Law, D. (1993) 'Global hegemony and the structural power of capital', in S. Gill (ed.) Gramsci, Historical Materialism and International Relations, Cambridge: Cambridge University Press.

Gillespie, W. (2006) 'Capitalist world economy, globalization, and violence: implications for criminology and social justice,' International Criminal Justice Review, 16, 1: 2444.

Gills, B. (2003) 'Globalization as global history: introducing a dialectical analysis', in M. Tétreault, R.A. Denemark, K.P. Thomas and K. Burch (eds) Rethinking Global Political Economy: Emerging Issues, Unfolding Odysseys, London: Routledge.

Gills, B. (2011) 'Globalization, crisis and transformation: world systemic crisis and the historical dialectics of capital', in B. Gills (ed.) Globalization in Crisis (Globalizations vol.11, 1/2), London: Routledge.

Gilpin, R. (1981) War and Change in World Politics, Cambridge: Cambridge University Press.

Gilpin, R. (1987) The Political Economy of International Relations, Princeton: Princeton University Press.

Gilpin, R. (2000) The Challenge of Global Capitalism, Princeton: Princeton University Press.

Gilpin, R. (2001) Global Political Economy. Understanding the International Economic Order, Princeton: Princeton University Press.

Girling, J. (1987) Capital and Power. Political Economy and Transformation, London: Croom Helm.

Giroux, H.A. (2008) Against the Terror of Neoliberalism, Boulder: Paradigm.

Glaser, B. (2014) 'China's grand strategy in Asia: statement before the US-China Economic and Security Review Commission May 2014', csis.org/files/attachments/ ts140313_glaser.pdf. 


\section{Bibliography}

Glyn, A. (2006) Capitalism Unleashed, Oxford: Oxford University Press.

Goh, E. (2013) The Struggle for Order: Hegemony, Hierarchy and Transition in PostCold War East Asia, Oxford: Oxford University Press.

Golding, S. (1992) Gramsci's Democratic Theory. Contributions to a Post-Liberal Democracy, Toronto: University of Toronto Press.

Goldner, L. (2009) 'Fictitious capital and the transition out of capitalism', libcom.org.

Gonzaga, E. (2009) Globalization and Becoming-Nation: Subjectivity, Nationhood and Narrative in the Period o Global Capitalism, Quezon: University of the Philippines Press.

Goodman, E.R. (1959) The Soviet Design for a World State, New York: Columbia University Press.

Gorz, A. (2011) Critique of Economic Reason, second edn, London: Verso.

Gray, C.S. (2005) 'In defence of the Heartland: Sir Halford Mackinder and his critics a hundred years on', in B.W. Blouet (ed.) Global Geostrategy: Mackinder and the Defence of the West, London: Cass.

Greenlaw, D., Hamilton, J.D., Hooper, P. and Mishkint, F.S. (2013) 'Crunch time: fiscal crises and the role of monetary policy', NBER Working Paper, www.nber. org/papers/w19297.

Grey, B. (2013) 'Turmoil in emerging economies a symptom of global crisis', www. wsws.org/en/articles/2013/08/27/econ-a27.html.

Grossheutschi, F. (1996) Carl Schmitt und die Lehre von Katechon, Berlin: Duncker \& Humblot.

Gruppe Krisis (1999) 'Manifesto against labour', www.krisis.org/1999/manifesto.

Guilhot, N. (2010) 'American Katechon: when political theology became international relations theory', Constellations, 17, 2: 224-253.

Guillén, M.F. and García-Canal, E. (2013) Emerging Markets Rule: Global Growth Strategies of the New Global Giants, New York: McGraw Hill.

Guillén, M.F. and Ontiveros, E. (2012) Global Turning Points: Understanding the Challenges for Business in the 21st Century, Cambridge: Cambridge University Press.

Gunder Frank, A. (1975) On Capitalist Underdevelopment, Bombay: Oxford University Press.

Gunder Frank, A. (1978) Dependent Accumulation and Underdevelopment, London: Macmillan.

Gupta, S. (2002) Corporate Capitalism and Political Philosophy, London: Pluto.

Guzzini, S. (2012) 'The ambivalent "diffusion of power" in global governance', in S. Guzzini and I.B. Neumann (eds) The Diffusion of Power in Global Governance, Basingstoke: Palgrave Macmillan.

Guzzini, S. and Leander, A. (2006) 'Wendt's constructivism: a relentless quest for synthesis', in S. Guzzini and A. Leander (eds) Constructivism and International Relations, London: Routledge.

Habermas, J. (1975) Legitimation Crisis, English trans., Boston: Beacon.

Habermas, J. (1984) The Theory of Communicative Action. Vol. I: Reason and the Rationalization of Society, English trans., Boston: Beacon.

Habermas, J. (1987) Philosophical Discourse of Modernity, English trans., Cambridge: Polity.

Haegen, P. van der and Viñals, J. (2003) 'European and Latin American experience in regional integration', in P. van der Haegen and J. Viñals (eds) Regional Integration in Europe and Latin America: Monetary and Financial Aspects, Aldershot: Ashgate. 
Hagan, S. (2010) 'Reforming the IMF', in M. Giovanoli and D. Devos (eds) International Monetary and Financial Law: The Global Crisis, Oxford: Oxford University Press.

Hagan, S. (2012) 'Enhancing the IMF's regulatory authority', in T. Cottier, J.H. Jackson and R.M. Lastra (ed.) International Law in Financial Regulation and Monetary Affairs, Oxford: Oxford University Press.

Haiven, M. (2010) 'Finance as capital's imagination? Reimagining value and culture in an age of fictitious capital and crisis', Social Text, 29, 3: 93-124.

Hallams, E. (2010) The United States and NATO since 9/11: The Transatlantic Alliance Renewed, London: Routledge.

Halliday, F. (1986) The Making of the Second Cold War, second edn, London: Verso.

Halligan, L. (2014) 'Russia-China gas deal could ignite a shift in global trading: Russia is increasingly looking east to China as a trading partner and that could mean an end to the dollar's dominance as a petrocurrency', www.telegraph.co.uk/ finance/comment/liamhalligan/10854595.

Hanieh, A. (2013) Lineages of Revolt: Issues of Contemporary Capitalism in the Middle East, London: Haymarket.

Hansen, B. (2011) Unipolarity and World Politics: A Theory and its Implications, London: Routledge.

Hanson, J. (1996) The Next Cold War? American Alternatives for the Twenty-First Century, Westport: Praeger.

Harding, R. (2014) 'US fails to approve IMF reforms', www.ft.com/14-01-2014.

Hardt, M. and Negri, A. (1994) Labor of Dionysus: A Critique of the State-Form, Minneapolis: University of Minnesota Press.

Hardt, M. and Negri, A. (2000) Empire, Cambridge, MA: Harvard University Press.

Harmes, A. (2008) 'The rise of neoliberal nationalism', Paper presented at the International Studies Association, March 2008, www.allacademic.com.

Harrod, J. (2006) 'The century of the corporation', in C. May (ed.) Global Corporate Power, Boulder: Lynne Rienner.

Hart-Landsberg, M. (2013) Capitalist Globalization: Consequences, Resistance and Alternatives, New York: Monthly Review Press.

Hart-Landsberg, M. and Burkett, P. (2006) 'China and the dynamics of transnational accumulation: causes and consequences of global restructuring', Historical Materialism, 14, 3: 3-43.

Hartnet, S.J. and Stengrim, L.A. (2006) Globalization and Empire: The US Invasion of Iraq, Free Markets and the Twilight of Democracy, Tuscaloosa, AL: University of Alabama Press.

Harvey, D. (2005 [1982]) The Limits to Capital, London: Verso.

Harvey, D. (1989) The Conditions of Postmodernity: An Enquiry into the Origins of Cultural Change, Oxford: Blackwell.

Harvey, D. (2003) The New Imperialism, Oxford: Oxford University Press.

Harvey, D. (2005) A Brief History of Neoliberalism, Oxford: Oxford University Press.

Harvey, D. (2010) 'The right to the city: from capital surplus to accumulation by dispossession', in S. Banerjee-Guha (ed.) Accumulation by Dispossession, New Delhi: Sage.

Haslam, J. (2005) The Nixon Administration and the Death of Allende's Chile, London: Verso.

Head, M. (2008) Evgeny Pashukanis: A Critical Reappraisal, London: RoutledgeCavendish.

Heater, D. (1996) World Citizenship and Government: Cosmopolitan Ideas in the History of Western Political Thought, London: Macmillan. 


\section{Bibliography}

Heater, D. (2000) 'Does cosmopolitan thinking have a future?', Review of International Studies, 26: 179-197.

Hedges, C. (2009) Empire of Illusion: The End of Literacy and the Triumph of Spectacle, New York: Nation Books.

Heinberg, R. (2005) The Party's Over: Oil War and the Fate of Industrial Societies, East Sussex: Clairview.

Heinrich, M. (2007) 'Profit without end: capitalism is just getting started', www.oeko nomiekritik.de.

Held, D. (1995) Democracy and the Global Order: From the Modern State to Cosmopolitan Governance, Cambridge: Polity.

Hell, J. (2009) 'Katechon: Carl Schmitt's imperial theology and the ruins of the future', The Germanic Review, 84, 4: 283-326.

Hellmann, G. (2008) 'Inevitable decline versus predestined stability: disciplinary explanations of the evolving transatlantic order', in J. Anderson, G.J. Ikenberry and T. Risse (eds) The End of the West? Crisis and Change in the Atlantic Order, Ithaca: Cornell University Press.

Henderson, J., Dicken, P., Hess, M., Coe, N. and Yeung, W.-C. (2002) 'Global production networks and the analysis of economic development', Review of International Political Economy, 9: 436-464.

Hendricks, C.L. (2008) 'Foucault's Kantian critique: philosophy and the present', Philosophy and Social Criticism, 34, 4: 357-382.

Hendrickson, J.M. (2013) Financial Crisis: The United States in the Early Twenty-first Century, Basingstoke: Palgrave Macmillan.

Henry, P.B. (2003) 'Capital account liberalization, the cost of capital, and economic growth', American Economic Review, 93, 2: 91-96.

Herd, G.P. and Dunay, P. (2010) 'International security, great powers and world order', in G.P. Herd and P. Dunay (eds) Great Powers and Strategic Stability in the 21st Century, London: Routledge.

Hettne, B. (2007) 'Interregionalism and world order: the diverging EU and US models', in M. Telò (ed.) European Union and New Regionalism: Regional Actors and Global Governance in a Post-Hegemonic Era, Aldershot: Ashgate.

Heymanns, S. (2013) 'NATO reform strengthens Germany's role', www.globalresearch. $\mathrm{ca} / 5356102$.

Hicks, S.V. (2002) 'Regionalism, globalism and the prospects for world order: a Hegelian approach', Interpretation: A Journal of Political Philosophy, 30, 1: 49-78.

Higgott, R.A., Underhill, G.R.D. and Bieler, A. (2000) Non-State Actors and Authority in the Global System, London: Routledge.

Higgs, R. (2007) 'Military-economic fascism: how business corrupts government and vice versa', The Independent Review, 12, 2: 299-316.

Hill, M. and Montag, W. (2000) 'What was, what is, the public sphere? Post-Cold War reflections', in M. Hill and W. Montag (eds) Masses, Classes, and the Public Sphere, London: Verso.

Hills, J. and Bastagi, F. (2013) 'Trends in the distribution of wealth in Britain', in J. Hills, F. Bastagli, F. Cowell, H. Glennerster, E. Karagiannaki and A. McKnight (eds) Wealth in the UK: Distribution, Accumulation, Policy, Oxford: Oxford University Press.

Hills, J. and Stewart, K. (2005) A More Equal Society? New Labour, Poverty, Inequality and Exclusion, Bristol: Policy Press.

Hiro, D. (2012) After Empire: The Birth of a Multipolar World, New York: Perseus. 
Hirsch, J. (1974) Staatsapparat und Reproduktion des Kapitals, Frankfurt-am-Main: Suhrkamp.

Hirst, P. (1994) Associative Democracy. New Forms of Economic and Social Governance, Cambridge: Polity.

Hirst, P. and Thompson, G. (1999) Globalization in Question. The International Economy and the Possibility of Governance, second edn, Cambridge: Polity.

Hobsbawm, E. (1992) Nations and Nationalism since 1780: Programme, Myth, Reality, second edition, Cambridge: Cambridge University Press.

Hobson, J.M. (2004) The Eastern Origins of Western Civilisation, Cambridge: Cambridge University Press.

Hoffman, M. (2007) 'Foucault's politics and bellicosity as a matrix for power relations', Philosophy and Social Criticism, 33, 6: 756-778.

Hoffman, P.T. (2011) 'Prices, the military revolution and western Europe's comparative advantage in violence', Economic History Review, 64, S1: 39-59.

Hoffmann, N. (2012) Renaissance der Geopolitik: Die deutsche Sicherheitspolitik nach dem kalten Krieg, Wiesbaden: Springer.

Hollis, S.A. (2009) "Neither slave nor free": the ideology of capitalism and the failure of radical reform in the American South', Critical Sociology, 35, 1: 9-28.

Holloway, J. and Picciotto, S. (1978) 'Introduction: towards a materialist theory of the state', in J. Holloway and S. Picciotto (eds) State and Capital: A Marxist Debate, London: Edward Arnold.

Hooy, C.-W., Ali, R. and Rhee, G. (2013) 'Emerging markets and financial resilience', in C.-W. Hooy, R. Ali and S.G. Ree (eds) Emerging Markets and Financial Resilience: Decoupling Growth from Turbulence, Basingstoke: Palgrave Macmillan.

Hoppe, C. (2008) 'Passing the buck: state responsibility for private military companies', European Journal of International Law, 19, 5: 989-1014.

Horn, M. (2002) Britain, France and the Financing of the First World War, Montreal: McGill-Queens University Press.

Huang, Y. (2008) Capitalism with Chinese Characteristics: Entrepreneurship and the State, Cambridge: Cambridge University Press.

Hudson, M. (2003) Super Imperialism. The Origins and Fundamentals of US World Dominance, second edn, London: Pluto.

Hudson, M. (2005) Global Fracture. The New International Economic Order, second edn, London: Pluto.

Hudson, M. (2010) 'Marx to Goldman Sachs: the fictions of fictitious capital and the financialization of industry', Critique: Journal of Socialist Theory, 38, 3: 419-444.

Hufbauer, G. and Xie, D.D. (2012) 'Financial stability and monetary policy: need for international surveillance', in T. Cottier, J.H. Jackson and R.M. Lastra (ed.) International Law in Financial Regulation and Monetary Affairs, Oxford: Oxford University Press.

Hung, H. (2008) 'Rise of China and the global accumulation crisis', Review of International Political Economy, 15, 2: 149-179.

Hüppauf, B. (1997) 'Modernity and violence: observations concerning a contradictory relationship', in B. Hüppauf (ed.) War, Violence and the Modern Condition, Berlin and New York: Walter de Gruyter.

Hurd, I. (2008) 'Theories and tests of international authority', in B. Cronin and I. Hurd (eds) The UN Security Council and the Politics of International Authority, London: Routledge.

Hutchings, K. (1999) International Political Theory, London: Sage. 
Hyland, J. (1995) Democratic Theory. The Philosophical Foundations, Manchester: Manchester University Press.

Hymer, S.H. (1979) The Multinational Corporation: A Radical Approach, Cambridge: Cambridge University Press.

Iammarino, S. and McCann, P. (2013) Multinationals and Economic Geography: Location, Technology and Innovation, Cheltenham: Edward Elgar.

Ikenberry, G.J. (2000) 'America's liberal grand strategy: democracy and national security in the post-war era', in M. Cox, G.J. Ikenberry, T. Inoguchi (eds) American Democracy Promotion: Impulses, Strategies and Impact, Oxford: Oxford University Press.

Ikenberry, G.J. (2001) After Victory: Institutions, Strategic Restraint and the Rebuilding of Order after Major Wars, Princeton: Princeton University Press.

Ikenberry, G.J. (2008) 'State power and international institutions: America and the logic of economic and security multilateralism', in D. Bourantonis, K. Ifantis and P. Tsakonas (eds) Multilateralism and Security Institutions in an Era of Globalization, London: Routledge.

Ikenberry, G.J. (2011) Liberal Leviathan: The Origins, Crisis and Transformation of the American World Order, Princeton: Princeton University Press.

Ikenberry, G.J. (2013) 'The liberal international order and its discontents', Millennium Journal of International Studies (10 May 2010).

Ikenberry, G.J., Mastanduno, M. and Wohlforth, W.C. (2011) 'Introduction: unipolarity, state behaviour and systemic consequences', in G.J. Ikenberry, M. Mastanduno and W.C. Wohlforth (eds) International Relations Theory and the Consequences of Unipolarity, Cambridge: Cambridge University Press.

IMF (2014) World Economic Outlook: Legacies, Clouds, Uncertainties, Washington: IMF Publication Services.

Ishchenko, R. (2015) 'What does Putin want?', http://thesaker.is/22-04-2015.

Israel, J. (1971) 'The principle of methodological individualism and Marxian epistemology', Acta Sociologica, 14, 3: 145-150.

Itoh, M. (1988) The Basic Theory of Capitalism: The Forms and Substance of the Capitalist Economy, Basingstoke: Macmillan.

Ivanova, M. (2010) 'A reversal of fortune: the (un)likely future of the dollar', Critique: Journal of Socialist Theory, 38, 1: 11-34.

Ivashov, L. (2011) 'BRICS and the mission of reconfiguring the world', www.volta irenet.com/article170451.

Ives, P. (2006) 'Language, agency and hegemony: A Gramscian response to PostMarxism', in A. Bieler and A.D. Morton (eds) Images of Gramsci: Connections and Contentions in Political Theory and International Relations, London: Routledge.

Ivry, B. (2014) The Seven Sins of Wall Street, New York: Public Affairs.

Jackson, P.T. (2010) 'The perpetual decline of the West', in C.S. Browning and M. Lehti (eds) The Struggle for the West: A Divided and Contested Legacy, London: Routledge.

Jameson, F. (2011) Representing Capital: A Reading of Volume One, London: Verso. Janes, J. and Nicholson, P. (2014) 'Remapping German-American relations', American Institute for Contemporary German Studies, www.aicgs.org/publications/14-12-2013.

Janszen, E. (2010) The Postcatastrophe Economy: Rebuilding America and Avoiding the Next Bubble, New York: Portfolio. 
Jervis, R. (2011) 'Unipolarity: a structural perspective', in G.J. Ikenberry, M. Mastanduno and W.C. Wohlforth (eds) International Relations Theory and the Consequences of Unipolarity, Cambridge: Cambridge University Press.

Jessop, B. (2001) 'What follows Fordism? On the periodization of capitalism and its regulation', in R. Albritton, M. Itoh, R. Westra and A. Zuege (eds) Phases of Capitalist Development: Booms, Crises and Globalization, Basingstoke: Palgrave Macmillan.

Jessop, B. (2004) 'Multi-level governance and multi-level metagovernance', in I. Bache and M. Flinders (eds) Multi-Level Governance, Oxford: Oxford University Press.

Jha, P.S. (2006) The Twilight of the Nation-State: Globalisation, Chaos and War, London: Pluto.

Joffé, G. (2001) 'European multilateralism and soft power projection in the Mediterranean', Zürcher Beiträge zur Sicherheitspolitik und Konfliktforschung, 61: 31-56.

Johnson, M. (2014) 'Globalization and decline of the West: Eurasianism, the state and the rebirth of ethnic socialism', www.eurasiareview.com/02052014.

Johnson, P. (2009) Habermas: Rescuing the Public Sphere, London: Routledge.

Johnson, S. (2009) 'The quiet coup', www.theatlantic.com/magazine/archive/2009/05/ the-quiet-coup/7364/.

Johnston, H. (2009) 'Protest cultures: performance, artefacts, and ideations', in H. Johnston (ed.) Culture, Social Movements and Protest, Aldershot: Ashgate.

Johnston, R.D. (2003) The Radical Middle Class. Populist Democracy and the Question of Capitalism in Progressive Era Portland, Oregon, Princeton: Princeton University Press.

Johnstone, D. (2002) Fools' Crusade. Yugoslavia, NATO and Western Delusions, London: Pluto.

Johnstone, D. (2014) 'Tightening the US grip on western Europe: Washington's Iron Curtain in Ukraine', www.globalresearch.ca/08-06-2014.

Jones, D.M., Khoo, N. and Smith, M.L.R. (2013) Asian Security and the Rise of China: International Relations in an Age of Volatility, Cheltenham: Edward Elgar.

Joseph, J. (2002) Hegemony. A Realist Analysis, London: Routledge.

Joseph, J. (2008) 'On the limits of neo-Gramscian international relations: a scientific realist account of hegemony', in A. Ayers (ed.) Gramsci, Political Economy and International Relations Theory, Basingstoke: Palgrave Macmillan.

Joshua, A. (2013) 'China takes control of Gwadar Port', www.thehindu.com/news/ 18-02-2013.

Kacowicz, A.M. (2013) Globalization and the Distribution of Wealth: The Latin American Experience, Cambridge: Cambridge University Press.

Kagan, R. (2004) Paradise and Power: America and Europe in the New World Order, New York: Atlantic.

Kagan, R. (2009) The Return of History and the End of Dreams, New York: Atlantic.

Kaldor, M. (2012) New and Old Wars: Organized Violence in Global Era, third edn, Cambridge: Polity.

Kalinichenko, D. (2014) 'Grandmaster Putin's golden trap', www.gold-eagle.com/0712-2014.

Kaplan, R. (2002) Warrior Politics: Why Leadership Requires a Pagan Ethos, New York: Vintage.

Kaplan, S.B. (2013) Globalization and Austerity Politics in Latin America, Cambridge: Cambridge University Press. 


\section{2}

Kashmeri, S.A. (2011) NATO 2.0: Reboot or Delete? Dulles: Potomac Books.

Kasturi, C.S. (2014) 'Delhi gears to join China-Russia club', www.telegraphindia.com/ 1140806.

Katzenstein, P.J. (1997) Tamed Power: Germany in Europe, Ithaca: Cornell University Press.

Katzenstein, P.J. (2006) 'East Asia beyond Japan', in P.J. Katzenstein and T. Shiraishi (eds) Beyond Japan: The Dynamics of East Asian Regionalism, Ithaca: Cornell University Press.

Kaufmann, C. and Weber, R.H. (2012) 'The role of transparency in financial regulation', in T. Cottier, J.H. Jackson and R.M. Lastra (ed.) International Law in Financial Regulation and Monetary Affairs, Oxford: Oxford University Press.

Kautsky, K. (1988 [1927]) The Materialist Theory of History, New Haven: Yale University Press.

Kawamura, T. (2013) 'The global financial crisis: the instability of US-centred global capitalism', in K. Yagi, N. Yokokawa, S. Hagiwara and G.A. Dymski (eds) Crises of Global Economies and the Future of Capitalism, London: Routledge.

Kay, G. (1988) 'Right and force: a Marxist critique of contract and the state', in M. Williams (ed.) Value, Social Form and the State, London: Macmillan.

Kay, G. and Mott, J. (1982) Political Order and the Law of Labour, London: Macmillan.

Kay, T. (2011) NAFTA and the Politics of Labor Transnationalism, Cambridge: Cambridge University Press.

Kearns, G. (2009) Geopolitics and Empire: The Legacy of Halford Mackinder, Oxford: Oxford University Press.

Keene (2009) 'International society as an ideal type', in C. Navari (ed.) Theorising International Society: English School Methods, Basingstoke: Palgrave Macmillan.

Keily, R. (2005) 'Capitalist expansion and imperialism-globalization debate: contemporary Marxist explanations', Journal of International Relations and Development, 8, 1: 27-57.

Kelso, L.O. and Kelso, P.H. (1986) Democracy and Economic Power, Cambridge, MA: Ballinger.

Kennan, G. (1948) 'Problem: the inauguration of organized political warfare', academ ic.brooklyn.cuny.edu/history.

Kennedy, P. (1987) The Rise and Fall of the Great Powers, New York: Vintage.

Keohane, R.O. (1984) After Hegemony: Cooperation and Discord in the World Political Economy, Princeton: Princeton University Press.

Keohane, R.O. (2001) 'Governance in a partially globalized world', American Political Science Review, 95, 1: 1-13.

Keohane, R.O. (2002) 'Moral commitment and liberal approaches to world politics', in E. Hovden and E. Keene (eds) The Globalization of Liberalism, Basingstoke: Palgrave Macmillan.

Keohane, R. and Nye, J.S. (2012 [1977]) Power and Interdependence, fourth edn, Boston, MA: Longman.

Keohane, R. and Nye, J.S. (2005 [1984]) After Hegemony: Cooperation and Discord in the World Political Economy, second edn, Princeton: Princeton University Press.

Keohane, R. and Nye, J.S. (1997) 'Interdependence in world politics', in G.T. Crane and A. Amawi (eds) The Theoretical Evolution of International Political Economy: A Reader, New York: Oxford University Press. 
Keping, Y. (2012) 'Globalization and state sovereignty', in C. Tuo (ed.) Chinese Perspectives on Globalization and Autonomy, Leiden: Brill.

Kerton-Johnson, N. (2011) Justifying America's Wars: The Conduct and Practice of US Military Intervention, London: Routledge.

Kicillof, A. and Starosta, G. (2007) 'On materiality and social form: A political critique of Rubin's value-form theory', Historical Materialism, 15, 3: 9-43.

Kiersey, N.J. (2008) 'World state or global governmentality? Constitutive power and resistance in a post-imperial world', Global Change, Peace and Security, 20, 3: $357-374$.

Kincaid, J. (2005) 'A critique of value-form Marxism', Historical Materialism, 13, 2: 85-119.

Kindleberger, C. (1973) The World in Depression, Berkeley: University of California Press.

Kindleberger, C. (1981) 'Dominance and leadership in the international political economy: exploitation, public goods and free rides', International Studies Quarterly, 27: 5-10.

King, G. (2009) 'Overcoming structure and agency: Talcott Parsons, Ludwig Wittgenstein and the theory of social action', Journal of Classical Sociology, 9, 2: 260-288.

King, J.E. (2011) 'Four theses on the global financial crisis', in S. Kates (ed.) The Global Financial Crisis: What Have We Learnt? Cheltenham: Edward Elgar.

King, S.D. (2013) When the Money Runs Out: The End of Western Affluence, New Haven: Yale University Press.

Kingston-Mann, E. (2006) 'The romance of privatisation and its unheralded challengers: case studies from English, Russian, Soviet and post-Soviet history', in F. von Benda-Beckmann, F. Von Benda-Beckmann, K. Von Benda-Beckmann and M.G. Wiber (eds) Changing Properties of Property, Oxford: Berghahn.

Kingstone, P. (2011) The Political Economy of Latin America: Reflections on Neoliberalism and Development, London: Routledge.

Kirk, D. (2015) 'China's Asian Infrastructure Investment Bank upsets US, lures US Allies including Korea', www.forbes.com/23-03-2015.

Kirton, J. (2013) G20 Governance for a Globalized World, Farnham: Ashgate.

Klare, M. (2008) Rising Powers, Shrinking Planet: How Scare Energy is Creating a New World Order, Oxford: Oneworld.

Klijn, E.-H. and Skelcher, C. (2007) 'Democracy and governance networks: compatible or not?', Public Administration, 85, 3: 587-608.

Kliman, A. (2007) Reclaiming Marx's 'Capital': A Refutation of the Myth of Inconsistency, Lanham: Lexington.

Knafo, S. (2002) 'The fetishizing subject in Marx's Capital', Capital and Class, 76, $145-175$.

Kober, S. (2009) 'NATO: the end of the permanent alliance', Global Dialogue, 11 (Winter/Spring): 74-81.

Koch, C. (2011) 'GCC states under the Obama administration', in S. Akbarzadeh (ed.) America's Challenges in the Greater Middle East: The Obama Administration's Policies, Basingstoke: Palgrave Macmillan.

Koenig, P. (2014) 'Russia's petroruble challenges US dollar hegemony. China seeks development of Eurasian trade', www.globalresearch.ca/08-04-2014.

Kolko, G. (1964) The Triumph of Conservatism: A Reinterpretation of American History, 1900-1916, New York: Free Press. 


\section{Bibliography}

Konings, M. (2008) 'The institutional foundations of US structural power in international finance', Review of International Political Economy, 15, 1: 35-61.

Konings, M. (2010) 'American finance and empire in historical perspective', in L. Panitch and M. Konings (eds) American Empire and the Political Economy of Global Finance, Basingstoke: Palgrave Macmillan.

Körber-Stiftung (2014) 'Einmischen oder zurückhalten? Ergebnisse einer repräsentativen Umfrage von TNS Infratest Politikforschung zur Sicht der Deutschen auf die Außenpolitik', www.koerber-stiftung.de/Mai2015.

Korybko, A. (2014) 'America's guide to dismantling the multipolar world', orientalre view.org/23-12-2014.

Kose, A. and Prasad, E.S. (2010) Emerging Markets: Resilience and Growth Amid Global Turmoil, Washington, DC: Brookings Institution Press.

Kotz, D.M. (1994) 'Interpreting the social structure of accumulation theory', in D.M. Kotz, T. McDonough and M. Reich (eds) Social Structures of Accumulation, Cambridge: Cambridge University Press.

Kotz, D.M. (2007) 'The erosion of non-capitalist institutions and the reproduction of capitalism', in R. Albritton, B. Jessop and R. Westra (eds) Political Economy and Global Capitalism, London: Anthem.

Krahmann, E. (2012) 'Private military and security companies, territoriality and the transformation of western security governance', in S. Guzzini and I.B. Neumann (eds) The Diffusion of Power in Global Governance, Basingstoke: Palgrave Macmillan.

Kramsch, O. and Hooper, B. (2004) 'Introduction', in O. Kramsch and B. Hooper (eds) Cross-Border Governance in the European Union, London: Routledge.

Krasner, S.D. (1978) Defending the National Interest: Raw Materials, Investments and US Foreign Policy, Princeton: Princeton University Press.

Krasner, S.D. (2005) 'The case for shared sovereignty', Journal of Democracy, 16, 1: 69-83.

Kratochwil, F. and Ruggie, J.G. (1986) 'International organization: a state of the art or an art of the state', International Organization, 40, 4: 753-775.

Krauthammer, C. (1991) 'The unipolar moment', Foreign Affairs, 70, 1: 23-33.

Krebs, P. (2012) Fighting for the Essence: Western Ethnosuicide or European Renaissance, English trans., London: Arktos.

Krippner, G.R. (2011) Capitalizing on Crisis: The Political Origins of the Rise of Finance, Cambridge, MA: Harvard University Press.

Krugman, P. (1991) 'Increasing returns and economic geography', Journal of Political Economy, 99, 3: 483-499.

Kumar, N. (2004) 'A vision of an Asian economic community', in N. Kumar (ed.) Towards an Asian Economic Community: Vision of a New Asia, New Delhi: RIS.

Kurihara, T. (2012) 'Achievements of Asian Bond Markets Initiative (ABMI) in the last decade and future challenges', www.oecd.org/finance/financial-markets/ 49700575.

Kurz, R. (1994) 'Das Ende der Politik: Thesen zur Krise des warenförmischen Regulationssystems', Krisis, 14, Bad Honnef: Horlemann.

Lacher, H. (2006) Beyond Globalization: Capitalism, Territoriality and the International Relations of Modernity, London: Routledge.

Lacher, H. (2008) 'History, structure and world orders: on the (cross-)purposes of neoGramscian theory', in A. Ayers (ed.) Gramsci, Political Economy and International Relations Theory, Basingstoke: Palgrave Macmillan. 
Laclau, E. (1977 [1971]) 'Feudalism and capitalism in Latin America', reprinted in E. Laclau, Politics and Ideology in Marxist Theory, London: NLB.

Lagadec, E. (2012) Transatlantic Relations in the 21st Century, London: Routledge.

Lane, J.-E. (2012) 'The European Union and NAFTA as models of regional integration', in N. Genov (ed.) Global Trends and Regional Development, London: Routledge.

Lang, K.-O. (2013) 'Germany's role in the Eurozone crisis', in R. Boyer, I.T. Berend and K. Haba (eds) The Euro Crisis and European Political Economy: France, Germany and Central Europe, Tokyo: Aoyama Gakuin University Press.

Langmore, J. and Fitzgerald, S. (2012) 'Strengthening global economic governance', in K. Macdonald, S. Marshall and S. Pinto (eds) New Visions for Market Governance: Crisis and Renewal, London: Routledge.

Lapavitsas, C. (2011) 'Theorizing financialization', Work, Employment and Society, 25, 4: 611-626.

Laruelle, M. (2012) 'Moscow's China dilemma: evolving perceptions of Russian security in Eurasia and Asia', in R.E. Bedeski and N. Swanström (eds) Eurasia's Ascent in Energy and Geopolitics: Rivalry or Partnership for China, Russia and Central Asia? London: Routledge.

Laruelle, M. and Peyrouse, S. (2013) Globalizing Central Asia: Geopolitics and the Challenges of Economic Development, Armonk: M.E. Sharpe.

Laski, H. (1936) The Rise of Liberalism: The Philosophy of a Business Civilization, New York: Harper.

Laumann, E.O. and Knoke, D. (1989) 'Policy networks of the organisational state', in R. Perrucci and H. Potter (eds) Networks of Power, New York: De Gruyter.

Lawrence, P.K. (1997) Modernity and War. The Creed of Absolute Violence, Basingstoke: Macmillan.

Layne, C. (2012) 'This time it's real: the end of unipolarity and the Pax Americana', International Studies Quarterly, 56: 203-213.

Lazonick, W. (2013) 'The fragility of the US economy: the financialized corporation and the disappearing middle class', in D. Breznitz and J. Zysman (eds) The Third Globalization: Can Wealthy Nations Stay Rich in the Twenty-first Century? Oxford: Oxford University Press.

Lazzarato, M. (2009) 'Neoliberalism in action: inequality, insecurity and the reconstitution of the social', Theory, Culture and Society, 26, 6: 109-133.

Lazzarato, M. (2012) The Making of The Indebted Man, English trans., New York: Semiotext(e).

Leahy, J. (2014) 'The BRICS bank is more about geopolitics than investment', blogs.ft. com/beyond-brics/16-07-2014.

Leander, A. (2010) 'The paradoxical impunity of private military companies: authority and the limits to legal accountability', Security Dialogue, 41, 5: 467-490.

LEAP (2014) 'Europe dragged into a division of the world between debtors and creditors: the United States' desperate solutions for not sinking alone', www.leap2020.eu.

Lebowitz, M.A. (1992) Beyond 'Capital', Basingstoke: Macmillan.

Leicht, K.T. and Fitzgerald, S.T. (2007) Post-Industrial Peasants: The Illusion of Middle Class Prosperity, New York: Worth.

Lembcke, J. (1988) Capitalist Development and Class Capacities, New York: Greenwood.

Lembcke, J. (2002) 'Labor and capital at the dawn of the twenty-first century', in B. Berberoglu (ed.) Labour and Capital in the Age of Globalization, Lanham: Rowman and Littlefield. 


\section{Bibliography}

Lenzner, R. (2010) 'Volcker says US economic and political influence globally is waning', www.huffingtonpost.com/01-12-2010.

Lepsius, M.R. (1993) Demokratie in Deutschland. Soziologish-historische Konstellationsanalysen, Göttingen: Vandenhoeck \& Ruprecht.

Letiche, J.M. (2007) Russia moves into the Global Economy, London: Routledge.

Levine, N. (2012) Marx's Discourse with Hegel, Basingstoke: Palgrave Macmillan.

Levinson, B.A.U. (2005) 'Citizenship, identity, democracy: engaging the political in the anthropology of education', Anthropology and Education Quarterly, 36, 4: 329-340.

Levitt, T. (1983) 'The globalization of markets', Harvard Business Review, 61, 3: 92-103.

Levy, J.S. (1983) War in the Modern Great Power System, 1495-1975, Lexington: University Press of Kentucky.

Leys, C. (2001) Market-Driven Politics. Neoliberal Democracy and the Public Interest, London: Verso.

Leys, C. (2008) Total Capitalism: Market Politics, Market State, Monmouth: Merlin.

Li, M. (2010) 'The end of the "end of history": the structural crisis of capitalism and the fate of humanity', Science and Society, 74, 3: 290-305.

Liagourias, G. (2005) 'The political economy of post-industrial capitalism', Thesis Eleven, 81: 20-35.

Lilley, S. (2010) 'Capitalist crisis: an interview with Leo Panitch, Sam Gindin and Greg Albo', www.globalresearch.ca/index.php?context=va\&aid=20457.

Lin, J.Y. (2013) Against the Consensus: Reflections on the Great Recession, Cambridge: Cambridge University Press.

Lin, Y.Y. and Dailami, M. (2011) 'Are we prepared for a multipolar world economy?', www.project-syndicate.org/commentary.

Ling, L.H.M. (2013) 'Worlds beyond Westphalia: Daoist dialectics and the "China threat", Review of International Studies, 39, 3: 549-568.

Liodakis, G. (2010) Totalitarian Capitalism and Beyond, Farnham: Ashgate.

Lipietz, A. (2001) 'The fortunes and misfortunes of post-Fordism', in R. Albritton, M. Itoh, R. Westra and A. Zuege (eds) Phases of Capitalist Development: Booms, Crises and Globalization, Basingstoke: Palgrave Macmillan.

Lipschutz, R. (2009) The Constitution of Imperium, Boulder: Paradigm.

Liu, X. (2012) The Mirage of China, Oxford: Berghahn.

Livingston, J. (1986) Origins of the Federal Reserve System: Money, Class and Corporate Capitalism, Ithaca: Cornell University Press.

Llobera, J. (2003) The Making of Totalitarian Thought, Oxford: Berg.

Lo, B. (2008) Axis of Convenience: Moscow, Beijing and the New Geopolitics, London: Chatham House.

Lo, B. (2012) 'The Russia-China-US triangle and its post-Cold War fate', in R.E. Bedeski and N. Swanström (eds) Eurasia's Ascent in Energy and Geopolitics: Rivalry or Partnership for China, Russia and Central Asia? London: Routledge.

Lo, D. and Zhang, Y. (2011) 'Making sense of China's economic transformation', Journal of Radical Political Economics, 43, 1: 33-55.

Lo, D. and Zhang, Y. (2010) China and the Global Financial Crisis, London: Centre for European Reform.

Lohoff, E. and Trenkle, N. (2012a) 'Making every central bank a bad bank: Ernst Lohoff and Norbert Trenkle discuss the economic and financial crisis [part 1]', Krisis: Kritik der Warengesellschaft, www.krisis.org. 
Lohoff, E. and Trenkle, N. (2012b) 'Making every central bank a bad bank: Ernst Lohoff and Norbert Trenkle discuss the economic and financial crisis [part 2]', Krisis: Kritik der Warengesellschaft, www.krisis.org.

Lohoff, E. and Trenkle, N. (2013) Die große Entwertung: vom finanzkapitalistischen Krisenaufschub zur globalen Notstandsverwaltung, Berlin: Unrast Verlag.

Lombardi, D. and Woods, N. (2008) 'The politics of influence: an analysis of IMF surveillance', Review of International Political Economy, 15, 5: 711-739.

Loughlin, M. and Walker, N. (eds) (2008) The Paradox of Constitutionalism. Constituent Power and Constitutional Form, Oxford: Oxford University Press.

Löwy, M. (1981) The Politics of Combined and Uneven Development: The Theory of Permanent Revolution, London: NLB.

Luce, E. (2014) 'America's democracy is fit for the one per cent', www.ft.com/ 30-03-2014.

Luhmann, N. (1990) Essays on Self-Reference, English trans., New York: Columbia University Press.

Lukács, G. (1923) 'Reification and the consciousness of the proletariat', in History and Class Consciousness: Studies in Marxist Dialectics, English trans., London: Merlin Press.

Lukes, S. (2005) Power: A Radical View, second edn, Cambridge: Polity.

Luxemburg, R. (1951 [1913]) Accumulation of Capital, English trans., London: Routledge \& Kegan Paul.

Lynn, B.C. (2010) Cornered: The New Monopoly Capitalism and the Economics of Destruction, Hoboken: John Wiley \& Sons.

Lynn, M. (2015) 'Three ways the rise of China's stock market will change the world', http://telegraph.co.uk/finance/China-business/13-04-2015.

Lyotard, J.-F. (1984) The Postmodern Condition: A Report on Knowledge, English trans., Manchester: Manchester University Press.

Macdonald, R. (2012) Genesis of the Financial Crisis, Basingstoke: Palgrave Macmillan.

MacDonald, S. (2014) 'Why political risk will dominate markets in 2014', www.the globalist.com.

Mackenzie, M. (2014) 'Russia dumps a fifth of its US Treasuries', www.ft.com/ 15-05-2014.

Mackinder, H. (1904) 'The geographical pivot of history', The Geographical Journal, 23, 4: 421-437.

MacLean, N. (2008) 'Southern dominance in borrowed language: the regional origins of American neoliberalism', in J.L. Collins, M. Di Leonardo and B. Williams (eds) New Landscapes of Inequality: Neoliberalism and the Erosion of Democracy in America, Santa Fe: School for Advanced Research Press.

Macleod, A. (2013) 'The great game accelerates', www.financeandeconomics.org/ 09-12-2013.

Macpherson, C.B. (1962) The Political Theory of Possessive Individualism: Hobbes to Locke, Oxford: Clarendon Press.

Mahbubani, K. (2013) The Great Convergence: Asia, the West and the Logic of One World, New York: Perseus Books.

Mahnken, T.G. (2012) 'Thinking about competitive strategies', in T.G. Mahnken (ed.) Competitive Strategies for the 21st Century: Theory, History and Practice, Stanford: Stanford University Press. 


\section{Bibliography}

Major, A. (2013) 'Transnational state formation and the global politics of austerity', Sociological Theory, 31, 1: 24-48.

Malamud, A. (2012) 'Moving regions: Brazil's global emergence and the redefinition of Latin American borders', in P. Riggirozzi and D. Tussie (eds) The Rise of Posthegemonic Regionalism: The Case of Latin America, Dordrecht: Springer.

Malešević, S. (2010) The Sociology of War and Violence, Cambridge: Cambridge University Press.

Mann, G. (2010) 'Value after Lehman', Historical Materialism, 18: 172-188.

Mann, M. (1993) The Sources of Social Power, Vol. II: The Rise of Classes and Nation-States 1760-1914, Cambridge: Cambridge University Press.

Manolopoulos, J. (2011) Greece's 'Odious Debt': The Looting of the Hellenic Republic by the Euro, the Political Elite and the Investment Community, London: Anthem.

Marazzi, C. (2010) The Violence of Financial Capital, English trans., New York: Semiotext(e).

Marazzi, C. (2011) Capital and Affects: The Politics of the Language Economy, New York: Semiotext(e).

March, J.G. and Olsen, J.P. (1989) Rediscovering Institutions. The Organizational Basis of Politics, New York: Free Press.

Marinov, M.A. and Marinova, S.T. (2013) 'The global crisis and the world: the cases of emerging and developed economies', in M.A. Marinov and S.T. Marinova (eds) Emerging Economies and Firms in the Global Crisis, Basingstoke: Palgrave Macmillan.

Marketos, T.N. (2009) China's Energy Politics, London: Routledge.

Marković, M. (1974) From Affluence to Praxis, English trans., Ann Arbor: University of Michigan Press.

Marshall, A.G. (2010) 'The transnational homeland security state and the decline of democracy', www.globalresearch.ca/index.php?context=va?aid=18676.

Marten, D. (2014) 'Are corporate mercenaries assisting neo-Nazis in Ukraine?', www. opednews.com/11-04-14.

Martenson, C. (2011) 'Living through an economic collapse', www.lewrockwell.com/ 2011/06/chris-martenson/living-through-an-economic-collapse.

Martin, P. (2011) 'Regional and global financial integration: an analytic framework', in M.B. Devereux, P.R. Lane, C.-Y. Park and S.-J. Wei (eds) The Dynamics of Asian Financial Integration: Facts and Analytics, London: Routledge.

Marton, P. and Matura, T. (2012) "The "voracious dragon", the "scramble" and the "honey pot": conceptions of conflict over Africa's natural resources', in D. Kopiński, A. Polus and I. Taylor (eds) China's Rise in Africa: Perspectives on a Developing Connection, London: Routledge.

Martynkewicz, W. (2013) Das Zeitalter der Erschöpfung: Die Überforderung des Menschen durch die Moderne, Berlin: Aufbau.

Marx, K. (1859) Contribution to the Critique of Political Economy. Marx-Engels Works Vol. 29, 254- 417.

Marx, K. (1936 [1847]) The Poverty of Philosophy, English trans., London: Lawrence \& Wishart.

Marx, K. (1959 [1894]) Capital: A Critique of Political Economy Volume III, English trans., London: Lawrence \& Wishart.

Marx, K. (1973) Grundrisse: Foundations of the Critique of Political Economy, English trans., London: Pelican. 
Marx, K. (1976 [1867]) Capital: A Critique of Political Economy Volume I, English trans., London: Penguin.

Mastanduno, M. (1999) 'A realist view: three images of the coming international order', in J.A. Hall and T.V. Paul (eds) International Order and the Future of World Politics, Cambridge: Cambridge University Press.

Matousek, R. and Stavárek, D. (eds) (2012) Financial Integration in the European Union, London: Routledge.

Mazhar, M.S., Javaid, U. and Goraya, N.S. (2012) 'Balochistan from strategic significance to US involvement', Journal of Political Studies, 19, 1: 113-127.

McAllister, G. and Sauvant, K.P. (2013) 'Foreign direct investment by emerging economy multinationals: coping with the global crisis', in M.A. Marinov and S.T. Marinova (eds) Emerging Economies and Firms in the Global Crisis, Basingstoke: Palgrave Macmillan.

McDonald, P.J. (2013) 'Capitalism, commitment and peace', in G. Schneider and N.P. Gleditsch (eds) Assessing the Capitalist Peace, London: Routledge.

McGrew, A. (2011) 'The logics of economic globalization', in J. Ravenhill (ed.) Global Political Economy, third edn, Oxford: Oxford University Press.

McKillop, A. (2014) 'Decline and the art of no economic growth', www.marketoracle. co.uk.

McMurtry, J. (2014) 'Global society destruction and the Ukraine crisis: decoding its deep structural meaning', www.globalresearch.ca/26-04-2014.

McNally, C.A. (2012) 'A macro-historical analysis: globalization, party-state and capital in China's emergent capitalism', in M. Ido (ed.) Varieties of Capitalism, Types of Democracy and Globalization, London: Routledge.

McNally, D. (2003) 'Beyond the false infinity of capital', in R. Albritton and J. Simoulidis (eds) New Dialectics and Political Economy, Basingstoke: Palgrave Macmillan.

McNally, D. (2009), 'From financial crisis to world-Slump: accumulation, financialization, and the global slowdown', Historical Materialism, 17, 2: 35-83.

McVeigh, P. (2005) 'Exporting and internalizing globalization: Canada and the global system of power', in G. Menz et al. (eds) Internalizing Globalization: The Rise of Neoliberalism and the Decline of National Varieties of Capitalism, Basingstoke: Palgrave Macmillan.

Meadway, J. (2014) 'The next financial crisis - not if but when', www.neweconomics. org/13-10-2014.

Meaney, M. (2002) Capital as Organic Unity: The Role of Hegel's Science of Logic in Marx's Grundrisse, Hamburg: Springer Press.

Mearsheimer, J. (2001) The Tragedy of Great Power Politics, New York: W.W. Norton.

Menz, G., Soederberg, S. and Cerny, P.G. (eds) (2005) Internalizing Globalization: The Rise of Neoliberalism and the Decline of National Varieties of Capitalism, Basingstoke: Palgrave Macmillan.

Meyssan, T. (2014) 'Washington re-launches its Iraq partition project', www.volta irenet.org/184359.

Mezzadra, S. and Neilson, B. (2013) 'Extraction, logistics, finance: global crisis and the politics of operations', Radical Philosophy, 178: 8-18.

Michalak, W. (1994) 'The political economy of trading blocs', in R. Gibb and W. Michalak (eds) Continental Trading Blocs: The Growth of Regionalism in the World Economy, Chichester: Wiley. 


\section{Bibliography}

Middelkoop, W. (2014) The Big Reset: War on Gold and the Financial Endgame, Amsterdam: Amsterdam University Press.

Miéville, C. (2004) 'The commodity-form theory of international law: an introduction', Leiden Journal of International Law, 17, 2: 271-302.

Milanovic, B. (2012) 'The real winners and losers of globalization', www.theglobalist.com.

Milberg, W. and Winkler, D. (2013) Outsourcing Economics: Global Value Chains in Capitalist Development, Cambridge: Cambridge University Press.

Miller, D. (2010) 'How neoliberalism got where it is: elite planning, corporate lobbying and the release of the free market', in K. Birch and V. Mykhnenko (eds) The Rise and Fall of Neoliberalism: Collapse of an Economic Order? London: Zed.

Milne, S. (2014) 'Far from keeping the peace, NATO is a threat to it', theguardian. com/03-09-2014.

Minin, D. (2013) 'The geopolitics of gas and the Syrian crisis: Syrian "opposition" armed to thwart construction of Iran-Iraq-Syria gas pipeline', www.globalresearch. $\mathrm{ca} / 03-06-2013$.

Minksy, H. (2008 [1986]) Stabilizing an Unstable Economy, New York: McGraw-Hill.

Mirhaydari, A. (2014) 'A currency war is coming: the race to the bottom could have disastrous effects', www.marketwatch.com/2014-04-23.

Mishkin, F.S. et al. (2013) 'Crunch time: fiscal crises and the role of monetary policy', NBER Working Paper, www.nber.org/papers/w19297.

Mishra, P. (2013) From the Ruins of Empire, London: Penguin.

Mitchell, K. (2003) 'Educating the national citizen in neoliberal times: from the multicultural self to the strategic cosmopolitan', Transactions of the British Institute of Geographers, 28, 4: 387-403.

Mittelman, J. (2011) 'What drives global security and insecurity?', Global Change, Peace and Security, 23, 2: 113-116.

Modelski, G. (1987) Long Cycles in World Politics, Seattle: University of Washington Press.

Moens, A. (2012) 'A hard act to follow: thoughts on world leadership in America's shadow', in S. Clark and S. Hoque (eds) Debating a Post-American World: What lies Ahead? London: Routledge.

Monteiro, D. (2014) Theory of Unipolar Politics, Cambridge: Cambridge University Press.

Moran, M. (2012) The Reckoning: Debt, Democracy and the Future of American Power, Basingstoke: Palgrave Macmillan.

Morris, I. (2013) The Measure of Civilisation: How Social Development Decides the Fate of Nations, London: Profile Books.

Mudunuru, L. (2013) 'BRICS in a multipolar world: the emerging geopolitical landscape', in J.M.S. Munoz (ed.) Handbook on the Geopolitics of Business, Cheltenham: Edward Elgar.

Müller, A. (2014) 'Deutsche Eliten setzen auf aggressivere Außenpolitik, Militarisierung und Krieg', www.nachdenkenseiten.de/?p=22292.

Müller, L. (1991) Gladio: Das Erbe des kalten Krieges. Das NATO Geheimbund und seine deutsche Vorläufer, Hamburg: Rowohlt.

Mumford, L. (1967) The Myth of the Machine: Technics and Human Development, London: Secker \& Warburg.

Murphy, C.N. (2000) 'Global governance: poorly done and poorly understood', International Affairs, 76, 4: 789-803. 
Murray, P. (1988) Marx's Theory of Scientific Knowledge, New Jersey: Humanities Press.

Musgrave, P. and Nexon, D. (2013) 'American liberalism and the imperial temptation', in N. Parker (ed.) Empire and International Order, Farnham: Ashgate.

Nace, T. (2003) Gangs of America: The Rise of Corporate Power and the Disabling of Democracy, San Francisco: Berrett-Koehler.

Napoleoni, L. (2009) Rogue Economics, London: Seven Stories Press.

Nash, K. (2010) Contemporary Political Sociology, second edn, Oxford: WileyBlackwell.

Nasser, A. (2013) 'The economics of over-ripe capitalism', www.counterpunch.org/ 03-05-2013.

National Security Strategy of the Russian Federation to 2020 (2009) www.isn.ethz.ch/ Digital-Library/Publications/Detail/?id=154915.

Navarro, L.S. (2011) 'The (geo)politics behind Europe's Libya split: does Germany's lack of support for action in Libya reflect "softness" and introversion?', www.europ eanvoice.com/13-04-2011.

Navarro, V. (2007) 'Neoliberalism as a class ideology', in V. Navarro (ed.) Neoliberalism, Globalization and Inequalities, New York: Baywood.

Nayyar, D. (2012) 'The global economic crisis: what does it mean for the developing world?', in M. Cohen (ed.) The Global Economic Crisis in Latin America, London: Routledge.

Nayyar, D. (2013) Catch Up: Developing Countries in the World Economy, Oxford: Oxford University Press.

Nazemroaya, M.D. (2007) 'Europe and America: sharing the spoils of war', www. globalresearch.ca/19-08-2007.

Nazemroaya, M.D. (2012) The Globalization of NATO, Atlanta, GA: Clarity.

Nesvetailova, A. (2013) 'Money and finance in a globalized economy', in R. Palan (ed.) Global Political Economy: Contemporary Theories, second edn, London: Routledge.

Neumann, F.L. (1942) Behemoth: The Structure and Practice of National Socialism 1933-1944, English trans., New York: Harper \& Row.

Niblett, R. (2010a) 'Introduction' in R. Niblett (ed.) America and a Changed World: A Question of Leadership, London: Wiley-Blackwell/Chatham House.

Niblett, R. (2010b) 'Europe: transatlantic relations still drifting', in R. Niblett (ed.) America and a Changed World: A Question of Leadership, London: Wiley-Blackwell/ Chatham House.

Nicolas, F. (2012) 'China and post-crisis regional financial cooperation in East Asia', in J.P. Cabestan, J.-F. Di Meglio and X. Richet (eds) China and the Global Financial Crisis: A Comparison with Europe, London: Routledge.

Nitzan, J. and Bichler, S. (2006) 'Cheap wars', Economy of the Occupation, 10, bna rchives.yorku.ca.

Nitzan, J. and Bichler, S. (2009) Capital as Power: A Study of Order and Creorder, London: Routledge.

Nitzan, J. and Bichler, S. (2012) 'The asymptotes of power', Real World Economics Review, 60: 18-53, bnarchives.yorku.ca.

Nitzan, J. and Bichler, S. (2014) 'Profit from crisis: why capitalists do not want recovery, and what that means for America', bnarchives.yorku.ca/396/02/20140419.

Nozick, R. (1974) Anarchy, State, Utopia, Oxford: Blackwell. 


\section{Bibliography}

Oba, M. (2013) 'Northeast Asia after the global financial crisis: power shift, competition and cooperation in the global and regional arenas', in T.J. Pempel (ed.) The Economy-Security Nexus in Northeast Asia, London: Routledge.

O'Brennan, J. (2014) "'On the slow train to nowhere". The European Union, "enlargement fatigue" and the western Balkans', European Foreign Affairs Review, 19, 2: 221-242.

O'Connor, J. (1984) Accumulation Crisis, New York: Basil Blackwell.

O'Connor, J. (1989) 'Introduction to a theory of crisis theories', in M. Gottdiener and N. Komninos (eds) Capitalist Development and Crisis Theory: Accumulation, Regulation and Spatial Restructuring, New York: St Martin's.

Offe, C. (1976) Disorganized Capitalism, English trans., Cambridge: Polity.

Offer, A. (2006) The Challenge of Affluence: Self-Control and Well-Being in the United States and Britain since 1950, Oxford: Oxford University Press.

O'Flynn, M. (2012) 'Capital accumulation and the historic decline of liberal individualism', Critical Sociology, 39, 4: 493-509.

Ojakangas, M. (2007) 'A terrifying world without an exterior: Carl Schmitt and the metaphysics of international (dis)order', in L. Odyssseos and F. Petito (eds) The International Political Thought of Carl Schmitt, London: Routledge.

OMFIF (Official Monetary and Financial Institutions Forum) (2013) 'Gold, the renmimbi and the multi-currency reserve system', www.omfif.org/intelligence/reports.

Orlov, D. (2011) Reinventing Collapse: The Soviet Experience and American Prospects, second edition, Gabriola: New Society.

Orum, A.M. and Dale, J.G. (2008) Political Sociology: Power and Participation in the Modern World, fifth edn, New York: Oxford University Press.

Osborne, E. (2007) The Rise of the Anti-Corporate Movement, Westport: Praeger.

Osborne, P. (2010) 'A sudden topicality: Marx, Nietzsche and the politics of crisis', Radical Philosophy, 150: 19-26.

Ostrogorski, M. (1902) Democracy and the Organization of Political Parties, 2 vols, English trans., New York: Haskel House.

O'Sullivan, M. (2000) Contests for Corporate Control. Corporate Governance and Economic Performance in the United States and Germany, Oxford: Oxford University Press.

O'Sullivan, N. (1988) 'The political theory of neo-corporatism', in A. Cox and N. O'Sullivan (eds) The Corporate State: Corporatism and the State Tradition in Western Europe, Aldershot: Edward Elgar.

Ottoway, M. (2001) 'Corporatism goes global: international organizations, nongovernmental organization networks and transnational business', Global Governance, 7, 3: 265-292.

Ouroussoff, A. (2010) Wall Street at War: The Secret Struggle for the Global Economy, Cambridge: Polity.

Overbeek, H. (2004) 'Transnational class formation and concepts of control', Journal of International Relations and Development, 7: 113-141.

Overbeek, H. (2013) 'Transnational historical materialism: "neo-Gramscian" theories of class formation and world order', in R. Palan (ed.) Global Political Economy: Contemporary Theories, second edn, London: Routledge.

Overbeek, H. and Van der Pijl, K. (1993) 'Restructuring capital and restructuring hegemony: neoliberalism and the unmaking of the post-war order', in H. Overbeek (ed.) Restructuring Hegemony in the Global Political Economy, London: Routledge. 
Palan, R. (2000) 'A world of their making: an evaluation of the constructivist critique in international relations', Review of International Studies, 26, 4: 575-598.

Palley, T.I. (2012) From Financial Crisis to Stagnation: The Destruction of Shared Prosperity and the Role of Economics, Cambridge: Cambridge University Press.

Pan, Z. and Chen, Z. (2012) 'Peaceful rise, multipolarity and China's foreign policy line', in T. Inoguchi and G.J. Ikenberry (eds) The Troubled Triangle: Economic and Security Concerns for the United States, Japan and China, Basingstoke: Palgrave Macmillan.

Panić, M. (2011) Globalization: A Threat to International Cooperation and Peace? Basingstoke: Palgrave Macmillan.

Panitch, L. and Gindin, S. (2004) 'Global capitalism and American empire', in L. Panitch and C. Leys (eds) The New Imperial Challenge: Socialist Register 2004, London: Merlin.

Panitch, L. and Gindin, S. (2008) 'Finance and American empire', in L. Panitch and M. Konings (eds) American Empire and the Political Economy of Global Finance, Basingstoke: Palgrave Macmillan.

Papageorgiou, E. (2013) 'Total social crisis and the return of fascism', Radical Philosophy, 181: 39-42.

Pape, R. (2005) 'Soft Balancing against the United States,' International Security, 30, 1: 7-45.

Pashukanis, E. (1951 [1924]) The General Theory of Law and Marxism, reprinted in H.W. Babb (trans.) Soviet Legal Philosophy, Cambridge, MA: Harvard University Press.

Patton, M. (2013) 'Is the US government too-big-to-fail?' www.forbes.com/sites.

Patton, P. (2000) Deleuze and the Political, London: Routledge.

Payne, C. (2012) The Consumer, Credit and Neoliberalism: Governing the Modern Economy, London: Routledge.

Pease, D. (2010) 'From virgin land to Ground Zero: the mythological foundations of the Homeland Security state', in G. Gunn and C. Gutiérrez-Jones (eds) America and the Misshaping of a New World Order, Berkeley: University of California Press.

Peet, R. (2009) Unholy Trinity: The IMF, World Bank and WTO, second edn, London: Zed Books.

Peetz, D., Murray, G. and Nienhüser, W. (2013) 'The new structuring of corporate ownership', Globalizations, 10, 5: 711-730.

Pei-Shan, K. (2013) 'Rethinking the development of US-China relations', in S. Burt and D. Ańorve Ańorve (eds) Global Perspectives on US Foreign Policy, Basingstoke: Palgrave Macmillan.

Pels, D. (1998) Property and Power in Social Theory. A Study in Intellectual Rivalry, London: Routledge.

Pena, D.S. (2001) Economic Barbarism and Managerialism, Westport: Greenwood.

Pennock, J.R. (1979) Democratic Political Theory, Princeton: Princeton University Press.

Penttinen, E. (2000) 'Capitalism as a system of global power', in H. Goverde, P.G. Cerny, M. Haugaard and H. Lentner (eds) Power in Contemporary Politics. Theories, Practices, Globalizations, London: Sage.

Pento, M.G. (2013a) The Coming Bond Market Collapse, Hoboken: Wiley.

Pento, M.G. (2013b) 'De-crowning the dollar', www.huffingtonpost.com/21-10-2013.

Perelman, M. (1987) Marx's Crisis Theory: Scarcity, Labor and Finance, New York: Praeger. 


\section{Bibliography}

Perkins, J. (2006) Confessions of an Economic Hit Man, London: Ebury.

Perrow, C. (2002) Organizing America: Wealth, Power and the Origins of Corporate Capitalism, Princeton: Princeton University Press.

Peters, T.J. and Waterman, R.H. (1982) In Search of Excellence, New York: Harper \& Row.

Petersen, A. (2011) The World Island: Eurasian Geopolitics and the Fate of the West, Santa Barbara: Praeger.

Petito, P. (2007) 'Carl Schmitt and the western-centric and liberal global order', in L. Odysseos and F. Petito (eds) The International Political Thought of Carl Schmitt, London: Routledge.

Petraki, A. and Zalewska, A. (2010) 'Growth prospects of new and old emerging markets', in G. N. Gregoriou (ed.) Emerging Markets: Performance, Analysis and Innovation, New York: CRC.

Petras, J. (2005) Empire with Imperialism: The Globalizing Dynamics of Neoliberal Capitalism, London: Zed.

Petras, J. (2008) 'Civil society and good governance: the politics of adjustment', in J. Veltmeyer (ed.) New Perspectives on Globalization and Anti-Globalization: Prospects for a New World Order? Aldershot: Ashgate.

Petras, J. (2009) 'Latin America: perspectives for socialism in a time of world capitalist recession/depression', Critique: Journal of Socialist Theory, 37, 3: 441-463.

Petras, J. and Veltmeyer, H. (2001) Globalization Unmasked: Imperialism in the 21st Century, London: Zed.

Petras, J. and Veltmeyer, H. (2007) Multinationals on Trial: Foreign Investment Matters, Aldershot: Ashgate.

Petras, J. and Veltmeyer, H. (2008) 'World development: globalization or imperialism?', in H. Veltmeyer (ed.) New Perspectives of Globalization and Antiglobalization, Aldershot: Ashgate.

Petras, J. and Veltmeyer, H. (2011) Beyond Neoliberalism: A World to Win, Farnham: Ashgate.

Pettifor, A. (2006) The Coming First World Debt Crisis, Basingstoke: Palgrave Macmillan.

Pfetsch, B. and Esser, F. (2004) 'Comparing political communication: reorientations in a changing world', in B. Pfetsch and F. Esser (eds) Comparing Political Communication: Theories, Cases and Challenges, Cambridge: Cambridge University Press.

Phelps, N.A. (2008) 'Cluster or capture? Manufacturing foreign direct investment, external economies and agglomeration', Regional Studies, 42: 457-473.

Phillips, P. and Osborne, B. (2013) 'Exposing the financial core of the transnational capitalist class', www.globalresearch.ca/5349617.

Picciotto, S. (2011) Regulating Global Corporate Capitalism, Cambridge: Cambridge University Press.

Pieterse, J.N. (2011) 'Global rebalancing: crisis and the east-south turn', Development and Change, 41, 2: 22-48.

Piketty, T. (2014) Capital in the Twenty-First Century, English trans., Cambridge, MA: Harvard University Press.

Plant, R. (2010) The Neoliberal State, Oxford: Oxford University Press.

Plehwe, D. (2009) 'Introduction', in P. Morowski and D. Plehwe (eds) The Road from Mont Pèlerin: The Making of the Neoliberal Thought Collective, Cambridge, MA: Harvard University Press. 
Plehwe, D. and Halpen, B. (2006) 'Between network and complex organization: the making of neoliberal knowledge and hegemony', in D. Plehwe, B. Walpen and G. Neunhöffer (eds) Neoliberal Hegemony: A Global Critique, London: Routledge.

Plehwe, D., Walpen, B. and Neunhöffer, G. (2006) 'Reconsidering neoliberal hegemony', in D. Plehwe, B. Walpen and G. Neunhöffer (eds) Neoliberal Hegemony: A Global Critique, London: Routledge.

Polanyi, K. (1944) The Great Transformation: The Political and Economic Origins of Our Time, Boston: Beacon.

Porfilio, B. and Malott, C. (2008) 'Introduction: the neoliberal social order', in B. Porfilio and C. Malott (eds) The Destructive Path of Neoliberalism: An International Examination of Urban Education, Rotterdam: Sense Publishers.

Porter, M.E. (1985) Competitive Advantage: Creating and Sustaining Superior Performance, New York: Free Press.

Porter, M.E. (1990) The Competitive Advantage of Nations, New York: Free Press.

Posen, B.R. (2011) 'From unipolarity to multipolarity: transition in sight?', in G.J. Ikenberry, M. Mastanduno and W.C. Wohlforth (eds) International Relations Theory and the Consequences of Unipolarity, Cambridge: Cambridge University Press.

Postone, M. (1993) Time, Labour and Social Domination: A Reinterpretation of Marx's Critical Theory, Cambridge: Cambridge University Press.

Postone, M. (2003) 'Lukács and the dialectical critique of capital', in R. Albritton and J. Simoulidis (eds) New Dialectics and Political Economy, Basingstoke: Palgrave Macmillan.

Postone, M. (2004) 'Critique and historical transformation', Historical Materialism, 12, 3: 53-72.

Postone, M. (2007) 'Theorizing the contemporary world: Robert Brenner, Giovanni Arrighi, David Harvey', in R. Albritton, B. Jessop and R. Westra (eds) Political Economy and Global Capitalism, London: Anthem.

Potts, N. (2010) 'Surplus capital: the ultimate cause of the crisis', Critique: Journal of Socialist Theory, 38, 1: 35-50.

Poulantzas, N. (1975) Classes in Contemporary Capitalism, English trans., London: New Left Books.

Pozo-Martin, G. (2007) 'Autonomous or materialist geopolitics?', Cambridge Review of International Affairs, 20, 4: 551-563.

Prasad, E.S. (2012) 'Emerging markets in the aftermath of the global financial crisis', in B. Eichengreen and B. Park (eds) The World Economy after the Global Crisis: A New Economic Order for the 21st Century, Singapore: World Scientific.

Prasad, E.S. (2014) The Dollar Trap: How the US Dollar Tightened its Grip on Global Finance, Princeton: Princeton University Press.

Prasad, M. (2006) The Politics of Free Markets. The Rise of Neoliberal Economic Policies in Britain, France, Germany and the United States, Chicago: University of Chicago Press.

Prebisch, R. (1950) The Economic Development of Latin America and Its Principal Problems, New York: United Nations.

Puche, J.S. (2000) 'Regionalism and the WTO', in WTO Secretariat (ed.) From GATT to the WTO: Rge Multilateral Trading System in the New Millennium, The Hague: Kluwer International.

Rabinovitch, S. (2014) 'Data underscore depth of China slowdown', www.ft.com/ 13-03-2014. 


\section{Bibliography}

Ransel, V. (2009) 'Cold case democracy and the doctrine of "corporate personhood", part II: smash and grab', www.globalresearch.ca.

Rapley, J. (2004) Globalization and Inequality: Neoliberalism's Downward Spiral, Boulder: Lynne Rienner.

Rapley, J. (2008) Understanding Development: Theory and Practice in the Third World, Boulder: Lynne Rienner.

Rasler, K. and Thompson, W.R. (2012) 'Systemic theories of conflict', in S. McLaughlin Mitchell, P.F. Diehl, J.D. Morrow (eds) Guide to the Scientific Study of International Processes, Malden, MA: Wiley.

Rawls, J. (2001) The Law of Peoples, Cambridge: Harvard University Press.

Reifer, T.E. (2004) 'Hegemony, state-corporate capitalism and anti-systemic movements: contending theoretical and historical approaches', in T.E. Reifer (ed.) Globalization, Hegemony and Power: Anti-Systemic Movements and the Global System, Boulder: Paradigm.

Reifer, T.E. (2005) 'Globalization, democratization and global elite formation in hegemonic cycles: a geopolitical economy', in J. Friedman and C. Chase-Dunn (eds) Hegemonic Decline: Past and Present, Boulder: Paradigm.

Reifer, T.E. (2012) 'State-corporate globalization and the rise and demise of the New World Order', in E. Wilson (ed.) The Dual State: Parapolitics, Carl Schmitt and the National Security Complex, Farnham: Ashgate.

Reiterer, M. (2014) 'The EU's comprehensive approach to security in Asia', European Foreign Affairs Review, 19, 1: 1-22.

Reus-Smit, C. (2005a) 'Constructivism', in S. Burchill, A. Linklater, R. Devetak, J. Donnelly, T. Nardin, M. Paterson, C. Reus-Smit and J. True, Theories of International Relations, third edn, Basingstoke: Palgrave Macmillan.

Reus-Smit, C. (2005b) 'Liberal hierarchy and the licence to use force', in J.D. Armstrong, T. Farrell and B. Maiguashca (eds) Force and Legitimacy in World Politics, Cambridge: Cambridge University Press.

Reuten, G. and Williams, M. (1989) Value Form and the State: The Tendencies of Accumulation and the Determination of Economic Policy in Capitalist Society, London: Routledge.

Rickards, J. (2011) Currency Wars: The Making of the Next Global Crisis, London: Penguin.

Rickards, J. (2014) The Death of Money: The Coming Collapse of the International Monetary System, London: Portfolio Penguin.

Rizzi, B. (1939 [1985]) The Bureaucratization of the World, London: Tavistock.

Roach, S. (2015) 'China at the crossroads: By continuing its economic rebalancing, China could increase the scale of its economy by trillions of dollars', www.thegloba list.com/15-04/2015.

Robert, P.C. and Maruschzik, J. (2013) The Failure of Laissez-Faire Capitalism, Atlanta: Clarity Press.

Roberts, D. (2008) Human Insecurity: Global Structures of Violence, London: Zed.

Roberts, J. and Ng, W. (2012) 'Against economic (mis)conceptions of the individual: constructing financial agency in the credit crisis', Culture and Organization, 18, 2: 91-105.

Roberts, M. (1996) Analytical Marxism: A Critique, London: Verso.

Roberts, P.C. (2010) How the Economy was Lost: The War of the Worlds, Petrolia: Counterpunch. 
Roberts, P.C. (2013) The Failure of Laissez-Faire Capitalism and the Economic Dissolution of the West, Atlanta: Clarity.

Robinson, W.I. (2002) 'Capitalist globalization and the transnationalization of the state', in M. Rupert and H. Smith (eds) Historical Materialism and Globalization, London: Routledge.

Robinson, W.I. (2004a) 'From state hegemonies to transnational hegemony: a global capitalism approach', in T.E. Reifer (ed.) Globalization, Hegemony and Power: AntiSystemic Movements and the Global System, Boulder: Paradigm.

Robinson, W.I. (2004b) A Theory of Global Capitalism: Production, Crisis and State in a Transnational World, Baltimore: Johns Hopkins University Press.

Robinson, W.I. (2006) 'Gramsci and globalisation: from nation-state to transnational hegemony', in A. Bieler and A.D. Morton (eds) Images of Gramsci: Connections and Contentions in Political Theory and International Relations, London: Routledge.

Robinson, W.I. (2007) 'Beyond the theory of imperialism: global capitalism and the transnational state', Societies Without Borders, 2: 5-26.

Robinson, W.I. (2008) Latin America and Global Capitalism: A Critical Globalization Perspective, Baltimore: Johns Hopkins University Press.

Robinson, W.I. (2011a) 'Globalization and the sociology of Immanuel Wallerstein: a critical appraisal’, International Sociology, 26, 6: 723-745.

Robinson, W.I. (2011b) 'The global capital leviathan', Radical Philosophy, 165: 2-6.

Robinson, W.I. and Harris, J. (2000) 'Towards a global ruling class? Globalization and the transnational capitalist class', Science and Society, 64, 1: 11-54.

Rode, R. (2007) 'Europäisches oder atlantisches Deutschland: die ökonomische Dimension', in T. Jäger, A. Höse and K. Oppermann (eds) Deutsche Außenpolitik, Wiesbaden: Verlag für Sozialwissenschaften.

Roemer, J. (1988) Free to Lose: An Introduction to Marxist Economic Philosophy, London: Radius.

Roland Berger Consulting (2011) 'Trend Compendium 2030', www.rolandberger.com/ gallery/trend-compendium/tc2030/content/assets/trendcompendium2030.pdf.

Rosamond, B. and Wincott, D. (2006) 'Constitutionalism, European Integration and British Political Economy', British Journal of Politics and International Relations, 8, 1: $1-14$.

Rosenau, J.N. (1992) 'Governance, order and change in world politics', in J.N. Rosenau and E.-O. Czempiel (eds) Governance without Government: Order and Change in World Politics, Cambridge: Cambridge University Press.

Rosenau, J.N. (2007) 'Governing the ungovernable: the challenge of a global disaggregation of authority', Regulation and Governance, 1: 88-97.

Rosenberg, J. (2013) 'The "philosophical premises" of uneven and combined development', Review of International Studies, 39, 3: 569-597.

Rothkopf, D.J. (2009) Superclass: The Global Power Elite and the World They are Making, New York: Farrar, Strauss \& Giroux.

Rowlands, G. (2012) The Financial Decline of a Great Power: War, Influence and Money in Louis XIV's France, Oxford: Oxford University Press.

Rozin, I. (2014) 'Shanghai Cooperation Organization ready to welcome new members', Russia \& India Report, in.rbth.com/2014/08/04.

Rueschemeyer, D., E. Huber Stephens and J.D. Stephens (1992) Capitalist Development and Democracy, Cambridge: Polity. 


\section{8}

Bibliography

Ruggie, J.G. (1993) 'Multilateralism: the anatomy of an institution', in J.G. Ruggie (ed.) Multilateralism Matters: The Theory and Praxis of an Institutional Form, New York: Columbia University Press.

Ruhl, L. (2007) 'Orientierung der deutschen Sicherheitspolitik: auf Europa oder Amerika?', in T. Jäger, A. Höse and K. Oppermann (eds) Deutsche Außenpolitik, Wiesbaden: Verlag für Sozialwissenschaften.

Rupert, M. (2006) 'Reading Gramsci in an era of globalising capitalism', in A. Bieler and A.D. Morton (eds) Images of Gramsci: Connections and Contentions in Political Theory and International Relations, London: Routledge.

Ruppert, M. (2004) Crossing the Rubicon: The Decline of the American Empire and the End of the Age of Oil, Vancouver: New Society.

Saad-Filho, A. (2010) Growth, Poverty and Inequality: From Washington Consensus to Inclusive Growth, DESA Working Paper 100, www.un.org/esa/desa/papers.

Saez, E. (2013) 'Striking it richer: the evolution of top incomes in the US [updated with 2012 preliminary estimates]', elsa.berkeley.edu/ saez/saez-UStopincomes-2012.pdf.

Safran, W. (1991) 'State, nation, national identity and citizenship: France as a test case', International Political Science Review, 12, 3: 219-238.

Sahoo, P. (2012) 'India and APEC: time to move from observer to member', www.ea stasiaforum.org.

Sandford, D. (2014) 'New US sanctions target Russian officials and companies', www. bbc.co.uk/news/world-27193628.

Sanyal, K. (2007) Rethinking Capitalist Development. Primitive Accumulation, Governmentality and Post-colonial Capitalism, New Delhi: Routledge.

Sarai, D. (2008) 'US structural power and the internationalization of the US Treasury', in L. Panitch and M. Konings (eds) American Empire and the Political Economy of Global Finance, Basingstoke: Palgrave Macmillan.

Saros, D.E. (2009) Labor, Industry and Regulation during the Progressive Era, London: Routledge.

Sassen, S. (1999) 'Embedding the global in the national: implications for the role of the state', in D.A. Smith et al. (eds) States and Sovereignty in the Global Economy, London: Routledge.

Sassen, S. (2011) 'A savage sorting of winners and losers: contemporary versions of primitive accumulation', in B.K. Gills (ed.) Globalization in Crisis, London: Routledge.

Sauer, T. (2014) 'Germany and others are doubtful about NATO', europesworld.org/ 18-02-2014.

Saull, R. (2007) The Cold War and After: Capitalism, Revolution and Superpower Politics, London: Pluto.

Saunders, P.C. (2008) 'China's role in Asia', in D. Shambaugh and M. Yahuda (eds) International Relations of Asia, Lanham: Rowman \& Littlefield.

Sava, I.N. (2004) Geopolitical Patterns of Euro-Atlanticism: A Perspective from Southeastern Europe, Camberley: Conflict Studies Research Centre.

Schepp, M. and Schmergal, C. (2014) 'The boomerang effect: sanctions on Russia hit German economy hard', www.spiegel.de/international/business/21-07-2104.

Schlichter, D.S. (2011) Paper Money Collapse, New York: John Wiley.

Schmid, G. (2001) 'On the existence of a global system for the interception of private and commercial communications - ECHELON interception system' (2001/2098 [NI]), European Parliament: Temporary Committee on the ECHELON interception system.

Schmidt, A. (1971 [1983]) History and Structure, English trans., Harvard: MIT Press. 
Schmidt, S. (2008) 'The reluctant ally: German domestic politics and the war against Saddam Hussein', in D.B. Bobrow (ed.) Hegemony Constrained: Evasion, Modification and Resistance to American Foreign Policy, Pittsburgh: University of Pittsburgh Press.

Schmied-Kowarzik, W. (1981) Die Dialektik der gesellschaftlichen Arbeit. Zur Genese und Kernstruktur der Marxschen Theorie, Freiberg: Alber.

Schmitt, C. (1942) 'Beschleuniger wider Willen, oder: Problematik der westlichen Hemisphäre', in G. Maschke (ed.) Staat, Grossraum, Nomos: Arbeiten aus den Jahren 1916-1969, Berlin: Duncker \& Humblot.

Schmitt, C. (1976 [1932]) The Concept of the Political, English trans., New Brunswick: Rutgers University Press.

Schmitt, C. (1985 [1922]) Political Theology, English trans., Chicago: University of Chicago Press.

Schmitt, C. (1996 [1927]) The Concept of the Political, English trans., Chicago: University of Chicago Press.

Schmitt, C. (2003 [1950]) The Nomos of the Earth, English trans., New York: Telos.

Schmitt, C. (2011a [1933]) 'Forms of modern imperialism in international law', English trans., reprinted in S. Legg (ed.) Spatiality, Sovereignty and Carl Schmitt: Geographies of the Nomos, London: Routledge.

Schmitt, C. (2011b [1939]) 'Grossraum versus universalism: the international legal struggle over the Monroe Doctrine', English trans., reprinted in S. Legg (ed.) Spatiality, Sovereignty and Carl Schmitt: Geographies of the Nomos, London: Routledge.

Scholte, J.A. (2011) 'Global governance, accountability and civil society', in J.A. Scholte (ed.) Building Global Democracy? Cambridge: Cambridge University Press.

Schortgen, K. (2013) 'US goes after BRIC nations to save dollar hegemony after failure in Syria', www.examiner.com/article/14-09-2013.

Schortgen, K. (2014) 'Bank deposits will soon no longer be considered money but paper investments', www.economicpolicyjournal.com/13-11-2014.

Scott, A.J. (1998) Regions and the World Economy: The Coming Shape of Global Production, Competition and Political Order, Oxford: Oxford University Press.

Scott, A.J. and Storper, M. (2003) 'Regions, globalization, development', Regional Studies, 37, 6/7: 579-593.

Scott, J. (1997) Corporate Business and Capitalist Classes, Oxford: Oxford University Press.

Scott, J. (2001) Power, Cambridge: Polity.

Scott, J. (2012) Sociological Theory: Contemporary Debates, second edition, Cheltenham: Edward Elgar.

Shaikh, A. (2005) 'The economic mythology of neoliberalism', in A. Saad-Filho and D. Johnston (eds) Neoliberalism: A Critical Reader, London: Pluto.

Shannon, V.P. (2005) 'Wendt's violation of the constructivist project: why a world state is not inevitable', European Journal of International Relations, 11, 4: 581-588.

Shaoul, J. (2014) 'Syria, Russia and Ukraine', www.wsws.org/en/articles/08-04-2014.

Sharma, R. (2013) 'Will China's takeover of Pakistan's Gwadar port be a game changer?', www.firstpost.com/india/04-02-2013.

Sheppard, E. and Barnes, T.J. (1990) The Capitalist Space Economy. Geographical Analysis after Ricardo, Marx and Saffra, London: Unwin Hyman. 
Sherman, D. (2011) 'Metapolitics now: Negri, critical theory, praxis', in P. Lamarche, M. Rosenkrantz and D. Sherman (eds) Reading Negri: Marxism in the Age of Empire, Chicago: Open Court.

Shiller, R.J. (2012) 'Financial capitalism: a safe venue for power struggles without violence', www.theglobalist.com/31-05-2012.

Simon, H.A. (1961 [1945]) Administrative Behaviour, New York: Macmillan.

Simon, J. (2008) 'NATO enlargement and Russia', in A. Braun (ed.) NATO-Russian Relations in the Twenty-First Century, London: Routledge.

Simoni, S. (2013) Understanding Transatlantic Relations: Whither the West? London: Routledge.

Simpfendorfer, B. (2011) The New Silk Road: How a Rising Arab World is Turning Away from the West and Rediscovering China, Basingstoke: Palgrave Macmillan.

Sinclair, T.J. (2012a) 'Stay on target! Implications of the global financial crisis for Asian capital markets', in S. Breslin (ed.) East Asia and the Global Crisis, London: Routledge.

Sinclair, T.J. (2012b) Global Governance, Cambridge: Polity.

Sjursen, H. (2012) 'Not so intergovernmental after all? On democracy, and integration in European foreign and security policy', in H. Sjursen (ed.) The EU's Common Foreign and Security Policy: The Quest for Democracy, London: Routledge.

Skarica, D. (2011) The Great Super Cycle: Profit from the Coming Inflation Tidal Wave and Dollar Devaluation, New York: Wiley.

Skelton, C. (2014) 'Bilderberg at 60', www.theguardian.com/world/29-05-2014.

Sklair, L. (2001) The Transnational Capitalist Class, Oxford: Blackwell.

Slaughter, A.-M. (2004) A New World Order, Princeton: Princeton University Press.

Slaughter, A.-M. (2005) 'Disaggregated sovereignty: towards the public accountability of global government networks', in D. Held and M. Koenig-Archibugi (eds) Global Governance and Public Accountability, Cambridge: Blackwell.

Smith, A., Stenning, A. and Willis, K. (eds) (2010) Social Justice and Neoliberalism, London: Zed.

Smith, D. (2006) Globalization: The Hidden Agenda, Cambridge: Polity.

Smith, K. (2011) 'South Africa and India as regional leaders of the global South', in R. Modi (ed.) South-South Cooperation: Africa on the Centre Stage, Basingstoke: Palgrave Macmillan.

Smith, M. (2014) 'The EU, the US and China: strategic engagement, political commitment and diplomatic interaction in multilateral arenas', in J. Men and W. Shen (eds) The EU, the US and China: Towards a New International Order? Cheltenham: Edward Elgar.

Smith, N. (2008) Uneven Development: Nature, Capital and the Production of Space, Oxford: Blackwell.

Smith, T. (2003) 'Systematic and historical dialectics: towards a Marxian theory of globalization', in R. Albritton and J. Simoulidis (eds) New Dialectics and Political Economy, Basingstoke: Palgrave Macmillan.

Soederberg, S. (2006) Global Governance in Question: Empire, Class and the New Common Sense in Managing North-South Relations, London: Pluto.

Soederberg, S. (2010) Corporate Power and Ownership in Contemporary Capitalism: The Politics of Resistance and Domination, London: Routledge.

Somers, M.R. (1999) 'The privatization of citizenship: how to unthink a knowledge culture', in V.E. Bonnell and L. Hunt (eds) Beyond the Cultural Turn: New Directions in the Study of Society and Culture, Berkeley: University of California Press. 
Sönmezler, G., Orcun Gündüz, I., Serkan Yürük, M. and Çetin-Gürkan, G. (2010) 'Effects of labour mobilization on ageing populations and the discrepancies of the EU', in S. Vettori (ed.) Ageing Populations and Changing Labour Markets: Social and Economic Impacts of the Demographic Time Bomb, Farnham: Gower.

Sørensen, M. and Christiansen, A. (2012) Ulrich Beck: An Introduction to the Theory of Second Modernity and the Risk Society, London: Routledge.

Spronk, S.J. (2004) 'The contradiction of capitalist sovereignty', paper presented at the annual meeting of the International Studies Association, Montreal, www.allacadem ic.com/meta/p72973.

Spykman, N.J. (1942) America's Strategy in World Politics. The United States and the Balance of Power, New York: Harcourt, Brace \& Co.

Standing, G. (2007) 'Offshoring and labor recommodification in the global transformation', in E. Paus (ed.) Global Capitalism Unbound: Winners and Losers from Offshore Outsourcing, Basingstoke: Macmillan.

Starosta, G. (2004) 'Editorial introduction: rethinking Marx's mature social theory', Historical Materialism, 12, 3: 43-52.

Starosta, G. (2010) 'Global commodity chains and the Marxian law of value', Antipode, 42, 2: 433-465.

Steil, B. and Litan, R.E. (2006) Financial Statecraft: The Role of Financial Markets in American Foreign Policy, New Haven: Yale University Press.

Stent, A.E. (2014) The Limits of Partnership: US-Russian Relations in the Twenty-first Century, Princeton: Princeton University Press.

Stephens, P. (2014) 'What Xi and Putin really think about the West', www.ft.com/ 05-06-2014.

Sterling-Folker, J. (2010) 'Neoliberalism', in T. Dunne et al. (eds) International Relations Theories: Discipline and Diversity, Oxford: Oxford University Press.

Stern, S.M. (1968) Aristotle on the World State, London: Cassierer.

Stiegler, B. (2010) For a New Critique of Political Economy, English trans., Cambridge: Polity.

Stiegler, B. (2011) The Decadence of Industrial Democracies, English trans., Cambridge: Polity.

Stiglitz, J. (2002) Globalization and its Discontents, New York: W.W. Norton.

Stiglitz, J.E. and Bilmes, L.J. (2008) The Three Trillion Dollar War: The True Cost of the Iraq Conflict, New York: Norton.

Stockhammer, E. (2011) 'Neoliberalism, income distribution and the causes of the crisis', in P. Arestis, R. Sobreira, J.L. Oreiro (eds) The Financial Crisis: Origins and Implications, Basingstoke: Palgrave Macmillan.

Stokes, D. (2004) America's Other War: Terrorizing Colombia, London: Zed.

Stone, D. (2000) 'Private authority, scholarly legitimacy and political credibility: think tanks and informal diplomacy', in R.A. Higgott, G.R.D. Underhill and A. Bieler (eds) Non-State Actors and Authority in the Global System, London: Routledge.

Stone, R.W. (2011) Controlling Institutions: International Organizations and the Global Economy, Cambridge: Cambridge University Press.

Stopford, J. and Strange, S. (1991) Rival States, Rival Firms. Competition for World Market Shares, Cambridge: Cambridge University Press.

Strachan, H. (2004) Financing the First World War, Oxford: Oxford University Press.

Stuenkel, O. (2014) 'BRICS undermine Western attempt to isolate Russia', www.post westernworld.com/2014/03/25.

Suarez-Villa, L. (2010) Technocapitalism: A Critical Perspective on Technological Innovation and Corporatism, Philadelphia: Temple University Press. 


\section{Bibliography}

Suarez-Villa, L. (2012) Globalization and Technocapitalism: The Political Economy of Corporate Power and Technological Domination, Aldershot: Ashgate.

Subacchi, P. and Pickford, S. (2011) 'Legitimacy vs. effectiveness for the G20: a dynamic approach to global economic governance', Chatham House International Economics Briefing Paper.

Sullivan, T.A. (2012) 'Debt and simulation of social class', in R. Brubaker, R.M. Lawless and C.J. Tabb (eds) A Debtor World: Interdisciplinary Perspectives on Debt, Oxford: Oxford University Press.

Sussex, M. (2014) 'The Shanghai Cooperation Organization: a future balancing coalition in Asia', in P. Shearman (ed.) Power Transition and International Order in Asia: Issues and Challenges, London: Routledge.

Svedberg, P. (2004) 'World income distribution: which way?', Journal of Development Studies, 40, 5: 1-32.

Swanström, N. (2012) 'Transformation of the Sino-Russian relationship: from Cold War to the Putin era', in R.E. Bedeski and N. Swanström (eds) Eurasia's Ascent in Energy and Geopolitics: Rivalry or Partnership for China, Russia and Central Asia? London: Routledge.

Switky, B. (2000) 'The importance of trading blocs: theoretical foundations', in B. Kerremans and B. Switky (eds) The Political Importance of Regional Trading Blocs, Aldershot: Ashgate.

Talani, L.S. (2012) Globalization, Hegemony and the Future of the City of London, Basingstoke: Palgrave Macmillan.

Tännsjö, T. (2008) Global Democracy: The Case for a World Government, Edinburgh: Edinburgh University Press.

Tanous, P. and Cox, J. (2011) Debts, Deficits and the Demise of the American Economy, New York: Wiley.

Taras, R. (2013) 'The power of images and the images of power: past and present identity in Russia's international relations', in R. Taras (ed.) Russia's Identity in International Relations: Images, Perceptions, Misperceptions, London: Routledge.

Taylor, G. (2010) The New Political Sociology: Power, Ideology and Identity in an Age of Complexity, Basingstoke: Palgrave Macmillan.

Teixeira, P.G. (2011) 'The regulation of the European financial market after the crisis', in P. della Posta and L.S. Talani (eds) Europe and the Financial Crisis, Basingstoke: Palgrave Macmillan.

Tellis, A.J. (2011) 'Creating new facts on the ground: why the diplomatic surge cannot yet produce a regional solution in Afghanistan', carnegieendowment.org/files/afgha n_policy.pdf.

Telò, M. (2007) 'Introduction: globalization, new regionalism and the role of the European Union', in M. Telò (ed.) European Union and New Regionalism: Regional Actors and Global Governance in a Post-Hegemonic Era, Aldershot: Ashgate.

Telò, M. and Ponjaert, F. (eds) (2013) The EU's Foreign Policy: What Kind of Power and Diplomatic Action? Farnham: Ashgate.

Tetalman, J. and Belitsos, B. (2005) One World Democracy: A Progressive Vision for Enforceable Global Law, San Rafael: Origin Press.

Teubner, G. (1997) Global Law without a State, English trans., Aldershot: Dartmouth.

Therborn, G. (2007) 'Europe: trading power, American hunting dog, or the world's Scandinavia?', in M. Telò (ed.) European Union and New Regionalism: Regional Actors and Global Governance in a Post-Hegemonic Era, Aldershot: Ashgate. 
Thies, W.J. (2009) Why NATO Endures, Cambridge: Cambridge University Press.

Thompson, A.A. (1974) The Economics of Corporate Capitalism and Corporate Power, New Jersey: University Programs Modular Studies.

Thompson, P. (2005) 'Foundation and empire: a critique of Hardt \& Negri', Capital and Class, 86: 39-64.

Thrift, N. (2005) Knowing Capitalism, London: Sage.

Tiezzi, S. (2014) 'The new, improved Shanghai Cooperation Organization: China's ambitious goals for the SCO are helped by the imminent addition of three new members', thediplomat.com/2014/09.

Titcombe, J. (2014) 'Britain's credit card addiction: in four scary charts', www.telegrap h.co.uk/25-11-2014.

Torre, A. de la, Gozzi, J.C. and Schmukler, S.L. (2007) 'Capital Market development: whither Latin America?', World Bank Policy Research Working Paper 4156, March 2007, elibrary.worldbank.org/doi/pdf.

Trägårdh, L. (2004) 'Introduction', L. Trägårdh (ed.) After National Democracy: Rights, Law and Power in America and the New Europe, Oxford and Portland: Hart.

Trotsky, L. (1977 [1933]) The History of the Russian Revolution, English trans., London: Pluto.

Tsatsanis, E. (2009) 'The social determinants of ideology: the case of neoliberalism in southern Europe', Critical Sociology, 35, 2: 199-223.

Tselichtchev, I. (2012) China versus the West: The Global Power Shift of the 21st Century, Singapore: Wiley.

Tsyganov, A.P. (2009) 'Blaming Moscow: the power of the anti-Russia lobby', Global Dialogue, 11 (Winter/Spring): 64-73.

Turnbull, G. (2014) 'Shields up: US expands missile defence into Europe and Asia', www.naval-technology.com/features/4215958.

UNESCAP (2012) 'Statistical yearbook for Asia and the Pacific 2012', www.unescap. org/stat/data.

Urry, J. (2003) Global Complexity, Oxford: Blackwell.

Van Camp, N. (2012) 'From biopower to psychopower: Stiegler's pharmacology of Mnemotechnologies', www.ctheory.net/articles.aspx?id=706.

Van der Linden, M. (2007) 'The "law" of uneven and combined development: some underdeveloped thoughts', Historical Materialism, 15, 1: 145-165.

Van der Pijl, K. (2001) 'International relations and capitalist discipline', in R. Albritton, M. Itoh, R. Westra and A. Zuege (eds) Phases of Capitalist Development: Booms, Crises and Globalization, Basingstoke: Palgrave Macmillan.

Van der Velden, D., Kruk, V. and Zifroni, G. (2008) 'Brand states: postmodern power, democratic pluralism, and design', worker01.e-flux.com/pdf/article_29.pdf.

Vangeli, A. (2013) 'On the obstacles to greater commitment in Sino-European relations: a European view', in F. Austermann, A. Vangeli, X. Wang (eds) China and Europe in 21st Century Global Politics: Partnership, Competition and Co-evolution, Cambridge: Cambridge Scholars Publishing.

Vaughan-Williams, N. (2011) 'The border', in S. Legg (ed.) Spatiality, Sovereignty and Carl Schmitt: Geographies of the Nomos, London: Routledge.

Veblen, T. (1932 [1904]) The Theory of the Business Enterprise, New York: Mentor.

Veblen, T. (1994 [1923]) Absentee Ownership and Business Enterprise in Recent Times: The Case of America, London: Routledge/Thoemmes Press.

Vestergaard, J. (2012) 'Disciplining the international political economy through finance', in S. Guzzini and I.B. Neumann (eds) The Diffusion of Power in Global 


\section{Bibliography}

Governance: International Political Economy meets Foucault, Basingstoke: Palgrave Macmillan.

Viden, A. (2014) 'Is the Saudi-US relationship broken?', www.e-ir.info/09-05-2014.

Volz, U. (2010) Prospects for Monetary Cooperation and Integration in East Asia, Cambridge, MA: MIT Press.

Wagner, P. (1994) A Sociology of Modernity. Liberty and Discipline, London: Routledge.

Walker, R. (1993) Inside/Outside: International Relations as Political Theory, Cambridge: Cambridge University Press.

Wallace, M. and Brady, D. (2010) 'Globalization or spatialization', in T. McDonough, M. Reich and D.M. Kotz (eds) Contemporary Capitalism and its Crises: Social Structure of Accumulation Theory for the 21st Century, Cambridge: Cambridge University Press.

Wallerstein, I. (1974) The Modern World-System, New York: Academic Press.

Wallerstein, I. (1995) After Liberalism, New York: Free Press.

Wallerstein, I. (2006a) European Universalism: The Rhetoric of Power, New York: New Press.

Wallerstein, I. (2006b) 'Globalization or the age of transition? A long-term view of the trajectory of the world-system', in S. Dasgupta and R. Kiely (eds) Globalization and After, New Delhi: Sage.

Wallerstein, I. (2010) 'Structural crises', New Left Review, 62: 133-142.

Wallerstein, I. (2011a) 'The limits of capitalism are hit/bifurcation: new hierarchic order or more democracy', www.kontext-tv.de/broadcast/29062011/immanuel-waller stein/capitalism.

Wallerstein, I. (2011b) 'Structural crisis in the world-system?', Monthly Review, 62, 10.

Walter, A. and Zhang, X. (2012) 'Debating East Asian capitalism', in A. Walter and X. Zhang (eds) East Asian Capitalism: Diversity, Continuity and Change, Oxford: Oxford University Press.

Walton, C.D. (2007) Geopolitics and the Great Powers in the Twenty-First Century: Multipolarity and the Revolution in Strategic Perspective, London: Routledge.

Waltz, K. (1993) 'The emerging structure of international politics', International Security, 18, 2: 44-79.

Waltz, K. (2000) 'Structural realism after the Cold War', International Security, 25, 1: 5-41.

Wapshott, N. (2013) 'Has military Keynesianism come to an end?', blogs.reuters.com/ nicholas-wapshott/2013/03/15.

Warner, J. (2014a) 'Want a scary view of where the economy is going?', telegraph.co. uk/finance/11-02-2014.

Warner, J. (2014b) 'Money printing, search for yield and the mirage of financial stability', telegraph.co.uk/finance/07-06-2014.

Warner, J. (2014c) 'Deflation: good, bad - and turning ugly: falling prices aren't always to be celebrated and the global financial crisis remains unsolved', www.telegraph.co. uk/finance/31-10-2014.

Weiler, Y.A. (2014) 'Pipeline predicament: the Ukraine-Syria-Russia-US gas nexus', www.tehrantimes.com/component/content/article/52-guests/114806/18-06-2014.

Weinstein, J. (1969) The Corporate Ideal in the Liberal State 1900-1920, Boston: Beacon Press.

Weirich, P. (2010) Collective Rationality: Equilibrium in Cooperative Games, Oxford: Oxford University Press. 
Wendt, A. (2003) 'Why a world state is inevitable', European Journal of International Relations, 9, 4: 491-542.

Wendt, A. (2005) 'Agency, teleology and the world state: a reply to Shannon', European Journal of International Relations, 11, 4: 589-598.

Westra, R. (2010) Political Economy and Globalization, London: Routledge.

Westra, R. (2012) The Evil Axis of Finance: The US-Japan-China Stranglehold on the Global Future, Atlanta, GA: Clarity.

Wheatley, A. (2013a) 'The origins and use of currency power', in A. Wheatley (ed.) The Power of Currencies and Currencies of Power, London: Routledge.

Wheatley, A. (2013b) 'The pretenders to the dollar's crown', in A. Wheatley (ed.) The Power of Currencies and Currencies of Power, London: Routledge/International Institution for Strategic Studies.

Whitney, M. (2014) 'Why is Putin in Washington's crosshairs?', www.counterpunch. org/2014/04/28.

Wiggin, A. (2014) 'Prepare for the death of the petrodollar', 4 June, dailyreckoning. com/prepare-for-the-death-of-the-petrodollar/.

Wild, F., Galvao, A. and Arkhipov, I. (2013) 'BRICS approve currency fund as bank start-up stalls', www.bloomberg.com/news/2013-03-27.

Wilks, S. (2013) The Political Power of the Business Corporation, Cheltenham: Edward Elgar.

Williamson, J. (2013) 'The dollar and US power', in A. Wheatley (ed.) The Power of Currencies and Currencies of Power, London: Routledge/International Institute for Strategic Studies.

Willie, J. (2013) 'The petrodollar sunset', www.silverdoctors.com/18-01-2013.

Willke, H. (2009) Governance in a Disenchanted World: The End of Moral Society, Cheltenham: Edward Elgar.

Willke, H. and Willke, G. (2012) Political Governance of Capitalism: A Reassessment Beyond the Global Crisis, Cheltenham: Edward Elgar.

Wilson, D.W. (1996) Rethinking Marx's value theory: the social and the free, Working Paper 42, London Guildhall University Department of Economics.

Wilson, E. (2009) 'Deconstructing the shadows', E. Wilson (ed.) Government of the Shadows: Parapolitics and Criminal Sovereignty, London: Pluto.

Wilson, E. (2012) 'The concept of the parapolitical', in E. Wilson (ed.) The Dual State: Parapolitics, Carl Schmitt and the National Security Complex, Farnham: Ashgate.

Winiecki, J. (2013) Economic Futures of the West, Cheltenham: Edward Elgar.

Winters, J.A. (2011) Oligarchy, Cambridge: Cambridge University Press.

Wolin, S. (2010) Democracy Incorporated: Managed Democracy and the Specter of Inverted Totalitarianism, Princeton: Princeton University Press.

Wood, E.M. (2002) 'Global capital, national states', in M. Rupert and S. Smith (eds) Historical Materialism and Globalization, London: Routledge.

Wood, N. (2004) Tyranny in America: Capitalism and National Decay, New York: Verso.

Woodley, D. (2013) 'Radical right discourse contra state-based authoritarian populism: neoliberalism, identity and exclusion after the crisis', in R. Wodak and J. Richardson (eds) Analysing Fascist Discourse: European Fascism in Talk and Text, London: Routledge.

Woods, R. (2010) 'The Sunday Times Rich List 2010: fortunes of the super-rich soar by a third', business.timesonline.co.uk/tol/business/specials/rich_list/article7107299.

Woolridge, A. (2012) 'The visible hand', www.economist.com/node/21542931. 


\section{Bibliography}

World Bank (2011) Multipolarity: The New Global Economy, Washington, DC: World Bank, siteresources.worldbank.org/INTGDH/Resources/GDH_CompleteReport2011.pdf.

World Bank (2014) International Debt Statistics 2014, Washington, DC: World Bank, openknowledge.worldbank.org/handle/10986/17048.

World Democracy Forum (2008) 'Shanghai Cooperation Organization: what are the threats to democrats and what can be done about them?', www.wmd.org/print/a ssemblies/fifth-assembly/reports/defending-civil-society-0/shanghai-cooperation-orga nization (see also: www.wmd.org/sites/default/files/5thAssemblyReport.pdf).

Worth, O. (2009) 'Beyond world order and transnational classes: the (re)application of Gramsci in global politics', in M. McNally and J. Schwarzmantel (eds) Gramsci and Global Politics: Hegemony and Resistance, London: Routledge.

Wouters, J. and Ramapoulos, T. (2012) 'The G20 and global governance: lessons from multilevel European governance', Review of International Economic Law, 15, 3: 751-775.

Wylde, C. (2012) Latin America after Neoliberalism: Developmental Regimes in PostCrisis States, Basingstoke: Palgrave Macmillan.

Yiwei, W. (2012) 'Seeking China's new identity: the myth of Chinese nationalism', in C. Tuo (ed.) Chinese Perspectives on Globalization and Autonomy, Leiden: Brill.

Yong, W. and Pauly, L. (2013) 'Chinese IPE debates on (American) hegemony', Review of International Political Economy, 20, 6: 1165-1188.

Yueh, L. (2013) 'The US, China and global imbalances', in L. Yueh (ed.) China and Globalization: Critical Concepts in Economics, London: Routledge.

Xinbo, W. (2010) 'Understanding the geopolitical implications of the global financial crisis', Washington Quarterly, 33, 4: 155-163.

Zakaria, F. (2011) Post-American World, second edn, London: Penguin.

Ziltener, P. (2012) 'Regional integration in East Asia as a reaction to global challenges', in N. Genov (ed.) Global Trends and Regional Development, London: Routledge.

Žižek, S. (2010) Living in the End Times, London: Verso. 


\section{Index}

accumulation crisis $50,53,57,107,112$, $121,125-6,139,142,212$

Afghanistan 118, 176-7, 195, 205

Africa 180, 182, 189, 190-2, 196

Agamben, G. 17, 36, 45, 91

Aglietta, M. 124

Ahmadinejad, M. 198

Ahmed, N. 213

Ahrari, E. M. 184, 191, 194

Al Assad, B. 201

Albritton, R. 37

Al Faisal, T. 199

alienated labour 27, 35

Althusser, L. 27, 89

American exceptionalism 117

Arab Spring 21, 199

Archibugi, D. 76, 177

Arendt, H. 27

Argentina 67, 93, 114, 120, 139, 161, 169-71

Arrighi, G. 4-5, 11, 14-15, 54, 11, 190-1

Arthur, C. 32-3, 36-7, 79

Asian Bond Fund Initiative (ABF) $165-6$

Asian financial crisis 96-7, 128, 164

Asian Infrastructure and Investment Bank (AIIB) 104, 193

Asia-Pacific Economic Cooperation (APEC) 98, 141

Association of South-East Asian Nations (ASEAN) 98, 141, 151, 165-6, 172, 204, 214

Australia 124, 157, 166, 209

Avineri, S. 154-5

Azerbaijan 195

Bacevich, S. 80

Balkans 146, 205-7, 214

Balochistan 205
Bank for International Settlements (BIS) 100,102

banks $39,41,58,93,100-1,103,106$, $110-3,119,124,136-8,155,165,171$, $192,201,213$

Baran, P. 112

Bauman, Z. 68

Beck, U. 203

Belgium 138

Bello, W. 90, 151, 158

Bhattacharyya, S. B. 146, 153, 164, 191

Bichler, S. 8, 16, 19, 49-50, 58-62, 110, 119-20, 183

Bieler, A. 66

Bilderberg 93

Bloch, E. 25, 27

Boggs, C. 16, 48, 51, 57, 68, 72

bond markets $59,113,119,129,135$, 138-40, 154, 162, 165, 167, 170-1

Bonefeld, W. 65

Boyle, N. 10, 74, 90

Brazil 1, 16, 21, 89, 104, 143, 152, 155-6, 161-4, 169, 171, 174, 192, 213

Brenner, R. 109, 121, 128-9

Breslin, S. 164

Bretton Woods 104, 115, 124, 131, 201

BRICS 1, 75, 151, 158, 162-4, 171, 185, 188-9, 196-202, 211, 214; BRICS bank 193; BRICS(A) currency 193

Brzezinski, Z. 176, 182, 184

Buck-Morss, S. 213

Bukharin, N. 92

Bull, H. 20

Bundesnachrichtendienst (BND) 207

Bush, G. W. 118-9

Buzan, B. 210

Cabrera, L. 82

Callinicos, A. 2, 11, 21-2, 91 


\section{Index}

Cameron, D. 205

Canada 157

Cantillon, R. 136

capitalist sovereignty. $1,3,14-5,18$, 22-8, 45, 47, 49-54, 56, 66, 69, 72, $74-8,84,89,95,99,108,139,178$, 213

Carroll, W. K. 19, 66, 92-5

Central Asia 2, 185, 194-7, 202, 208

CENTCOM (US Military Central Command) 182, 188

Central Intelligence Agency (CIA) 176

Chiang Mai Initiative 75, 165

Chile 67, 161, 167

China 1-3, 6, 14, 16, 51, 74, 120-1, 127, 142-4, 151-4, 165-6, 171-3, 175-80, 184-202, 204, 206, 208-9, 211-14;

Asian regionalism and 151-2; currency (renmimbi) 143, 166, 176, 182, 191; Grand Strategy 184-202; growth 157-8; new international financial institutions 104; new 'Silk Road' project 21, 199; regional aspirations 171; Sino-Russian partnership 193-7

Chossudovsky, M. 110

Clarke, S. 39, 112, 125, 127

Clinton, W. J. 118

Coase, R. 51

Cohen-Tanugi, L. 178, 182

Cold War 5-6, 15, 115, 182, 188, 202, 209, 214

Collective Security Treaty Organization (CSTO) 171, 196-7

colour revolution 196

commodity fetish $32,55,133$

communism 114-5

competition state $66,68,73,168$

constructivism $88-9$

corporate globalization 1, 12, 17, 23-4, $30,51-8,68,77,91,116,147,172$ corporate power, $2-4,10,12,17-21$, $24-5,28-31,44-5,48-59,63-4,66$, 68-9, 72, 75, 77, 89-98, 102, 110, 117, $127,153,178-80,210$

cosmopolitanism 20, 83, 85, 177-8

Council on Foreign Relations 103

counterinsurgency 117

Cox, R. W. 11, 13, 57-8, 61, 68, 88, 127, 138,151

Crimea 207-8

Crouch, C. 47, 70

Cutler, C. 12,67
De Angelis, M. 30, 32

debt 10, 20, 39-40, 43, 50-1, 57-8, 61, 64, 69-72, 84, 97, 99-103, 106-22, 125-32, 134, 142, 151-2, 163, 167, $169,171,186,192-3,203-4,211$; debt crisis of the West 129-39

defence spending $125,176-8,203-7$

deflation 51, 53, 93, 109, 119-20, 128-30, $135,139,155,183,203,212$

Deleuze, G. \&, F. Guattari 24, 62, 76, democracy 3, 14, 43-4, 51, 61, 67, 72, $82-4,103,118,120,167,177,183$

dependency theory 115

derivatives $9,21,132-4,138$

D'Estaing, O. G. 74

deterritorialization $6,24,89,98,147$, 178

differential accumulation 20, 49-50, $56-62,72$

Dirlik, A. 142

Domhoff, G. W. 29, 61

dominant capital 7, 18-20, 44, 49, 50, 56, 58-63, 70, 72, 92-3, 101-2, 119-20, $134,183,213$

dual state 4

Dugin, A. 105, 202

Duménil, G. 57

Echelon 209, 215

economic geography $3,141-8$

efficient market theory 40

Egypt 21, 155, 161

Ehteshami, A. 184

Eichengreen, B. 131

Emergency Economic Stabilization Act (US law) 44

emerging market economies $4,9,13,18$, $75,104,134,141-64$

energy $7,15,18,74,89,111,119-20$, $138,140,152,171,175,179,181-2$, $184-5,189,198-202 ; 207-8$

energy pipelines 119, 196

Engdahl, F. W. 111, 113

English School 80, 214

Enlightenment 82-3, 85

Eurasia (geopolitical space) 2, 5, 73, 119 , 192-8, 199-202; as object of US geostrategy 175, 179-89

Eurasian Balkans 119, 181-2

Eurasian Economic Union (EEU) 149, $171-2,197$

Euromaidan protests (Ukraine) 202

European Central Bank (ECB) 119, 171, 204-5 
European Union (EU) 2, 3, 7, 61, 71, 79, 83-4, 86-7, 97-8, 131, 137, 140 142, 146, 151, 161, 163, 171-2, 179-95; Eurozone crisis 83-4, 97, 131, 137, 202-8; German leadership of 202-8; Neighbourhood Policy 181

Evans-Pritchard, A. 164, 193

fascism 56, 65, 70, 79, 94, 110, 124, 128, 205,

Falk, R. 85, 177

Federal Reserve Bank 5, 53, 97, 118, 120, 124, 130, 136-8, 140, 155, 171,

Feenberg, A. 25, 27, 38

fictitious value $7,9,134,140$,

financialization $5,7,9,11,14-17,25$, 39-40, 58, 69, 107-9, 123, 127, 132, $139,152-3,163$

financial socialism 9, 101, 110

Financial Stability Board 102

financial surveillance 74, 77, 96-104

First World War 111-4

Flores-Macías, G. A. 146, 167

Fordism 15, 57, 125

foreign direct investment (FDI) 2, 16, 104 ; in emerging market economies 141-62

Foucault, M. 113, 132

Fourth World 71

Fouskas, V. K. 107, 119

France 21, 84, 111, 188, 203-7, 209

Functionalism 81

G7 9, 96-7, 102, 141, 180

G20 75-6, 82, 96-8, 100-5

Gabriel, S. 215

Gamble, A. 110, 180

Ganser, D. 182

Gauck, J. 206

Gawel, K. 36, 42-3

Gazprom 192, 207

GCHQ 209

Gellner, E. 76

Georgia 187-8, 196

Germany 21, 49, 63, 67, 73, 84, 111, 114, $119,150,154,172-3,176,180$. 186-8; leadership in EU, 202-8; difficult relations with US 203, 206-7; foreign policy, 180, 205, 208; leadership of EU 202-8; relations with Russia 188-92

Gerschenkron, A. 160

Giddens, A. 76, 88

Gill, S. 13-4, 69

Gilpin, R. 5, 80
Gindin, S. 11, 13

global financial crisis $4,7,13,18,44-5$, 47, 58, 74-5, 78, 90, 101-5, 106, 128, $151,172,181$; impact on emerging market economies 158-62, 165, 169; failure of policy response in the West 135-9, 204

global GDP 21, 142, 159-61

global governance 1, 4-6, 12, 18, 23, 69, $72-8,91-2,88-92,96-8,101-5$

globalism 28, 70, 78-9, 145, 209

gold 15, 114, 124, 137-8, 175-6, 191,

198; artificial suppression of 138 ;

Chinese and Russian policy 211-2; gold standard 124; remonetization of 211

Gorz, A. 36,

Great Depression 109, 124, 130

Great Terror 55

Greece 82-6, 114

Gruppe Krisis 173

Gulf Cooperation Council (GCC) 141, 149, 181, 199

Gunder Frank, A. 114, 116

Gupta, S. 45, 49

Guzzini, S. 10, 83, 88

Gwadar (Pakistan) 215

Habermas, J. 32, 41, 68

Haiven, M. 41-2

Halliday, F. 66

Halligan, L. 192-3

Hanieh, A. 11, 71, 107, 181, 199

hard balancing 5

Hardt, M. \& Negri, A. 8, 23-4, 42

Harvey, D. 8-9, 11, 35, 39, 42, 67, 142, 147,212

Haushofer, K. 184, 205

Heartland theory 73, 181-3, 195

Hedges, C. 5

Hegel, G. W. F. 31-6, 90, 123

hegemonic stability theory 4

Heinberg, R. 7

Heinrich, M. 106, 144

Held, D. 76

Hettne, B. 180, 189

Hezbollah 201

Hiro, D. 6

Holloway, J. \& Picciotto, S. 64, 77

Huang, Y. 190

Hudson, M. 5, 114-5, 124

humanitarian intervention 89, 118, 206

hyperinflation 137, 169, 182, 211

hypermodernity 29 


\section{Index}

Ikenberry, G. J. 4, 14, 210

India 1, 6, 16, 21, 51, 104-5, 120, 141, $144,146,155,157-8,161-4,166$, 172-3; counterweight to China 191, 198, 213; accession to SCO 198-200; relations with China 200

inequality $23,51,57,108,160,167,173$, 183

Indonesia 16, 21, 101,

inflation 9, 58, 64, 77, 97, 109, 119-21, $124,130-9,164,169,182-3,211$

intergovernmentalism $73,77,79,83-4$, 96-100, 103, 114, 146, 197-8, 205

International Monetary Fund (IMF) 1, 40-3, 75-6, 80, 84, 96-101, 104-05, $126,37,141,145,164,167,169$, 171-2, 200-1; relation to G20 97; relation to EU 'Troika' 84; IMF structural adjustment programs (SAPs) 96, 126

investor class, 3, 66, 110, 161, 177

Iran $6,90,138,155$; future accession to SCO 199; counterhegemonic regional power 176, 181, 189; relations with China 198-9; US tilt towards 181

Iraq 4-5, 118-9, 176-7, 180-81, 186, 194, 198; 206, 214; ISIL insurgency 199, 202

Islamic State in the Levant (ISIL) 199 , 202

Islamism 196

Israel 209, 211

Italy $21,188,202,204$

Itoh, M. 64-5

Ivashov, M. 200

Ivy League 211

Janszen, E. 151, 163

Japan 7, 21, 49, 63, 69, 124, 127-8, 131, $137,142,153-4,157,161,165-6$, 170-2, 191, 209; economic decline $148-52$

Jessop, B. 84, 124

Jinping, X. 175, 200

Joseph, J. 89

Juncker, J-C. 205

Kacowicz, A. M. 167-8

Kagan, R. 182

Kaldor, M. 177

Kalinichenko, D. 211-12

Kant, I. 85

Kashgar (China) 215

Kazakhstan 155, 195
Kellogg-Briand Pact 118

Keohane, R. 10, 79, 81, 105

Kirchner, C. F. de 93

Kirton, J. 78, 82, 103

Kolko, G. 49, 53

Kondratieff cycle 11, 124

Konings, M. 5, 121

Körber-Stiftung 205

Kosovo 205-7

Kotz, D. 4, 57, 123

Krugman, P. 148

Kurz, R. 72

Kyrgyzstan 195-6

labour 2, 4, 7-9, 15, 18-9, 47, 51, 53-4, 57, 64-9, 70-3, 88-91, 95, 108-9, 112, $116-7,119,141,145-9,152-3,157$, $160-61,164,167,172-3,179,189$; abstract labour 25-43; and accumulation crisis 121-34; labour theory of value 8

Lacher, H. 88

Laclau, E. 116

Laski, H. 18

Latin America 2, 57, 73, 92, 143, 146, $155,158-72,180,189$

Lazzarato, M. 40, 79, 108, 121

Lembcke, J. 125

Lenin, V. I. 29, 91-2, 173

Lévy, D. 57

Leys, C. 68, 168

liberal universalism 3-4, 82, 89, 183

liquidity fetish 118-21

Lockean heartland 1, 6, 90, 142, 185, 188,190

London Conference (1933) 114

Luhmann, N. 49

Lukács, G. 27, 31, 38

Luxemburg, R. 24, 29

Mackinder, H. 183-5, 205

Macpherson, C. B. 26

Magdoff, H. 7, 109, 130, 132

Mahan, A. T. 184

Mahbubani, K. 18

Malešević, S. 183

Maoism 190

Marković, M. 25

Marx, K. 1, 2, 4, 7-8, 12, 21, 47, 59, 65, $73,89,94,108,122-3$; theory of capital 25-38

Mastanduno, M. 10, 80

McGrew, A. 82-3

McNamara, R. 114-15 
Mearsheimer, J. 4, 208

Mediterranean 181, 202

mercantilism 3

Mercosur 170

Merkel, A. 205, 208

Mexico 21, 128, 152, 157, 161, 171-2

Middle East-North Africa (MENA) 2, 107, 141, 146, 172-3, 179, 181, 186, 188-9, 192, 198

Middelkoop, W. 140, 176, 182

Miéville, C. 55-6

Militarism 17, 183

Minsky, H. 130

Mishra, P. 108

mnemotechnics 40, 46

Modi, R. 199

Mongolia 198

Monroe Doctrine 73

Monteiro, D. 4, 14, 209-10

Morton, A. D. 66

multilateralism 2, 5, 75, 80, 103, 105, 143, 146, 148-50, 180, 185-6, 189, 197, 201, 204, 208-10

multiplier effect 113, 173

multipolarity $1,6,34,73-5,90,142-4$, 156, 161-3, 178, 180, 181, 190-4, 200, 209-10, 213-4; multipolar regionalism 180; western ambivalence towards 181-9

Mumford, L. 19

National Security Agency (NSA) 209

Nayyar, D. 151, 159-61

Nazemroaya, M. D, 151, 173, 182, 186

neoconservatism 182, 185, 191, 207

neo-developmentalism 164-168-9,

neo-Gramscian theory $11,13,88$

neoliberalism 5, 50, 56-7, 65-73

neopluralism 29

New Deal 58, 69, 183

new economic regionalism 145-51

new Silk Road, 21, 199

Nietzsche, F. 40

Nitzan, J. 8, 16, 19, 49-50, 58-62, 110, 119-20, 183

Non-Aligned Movement 116

Nord Stream pipeline 207

North American Free Trade Agreement (NAFTA) 3, 149, 172, 189

North Atlantic Treaty Organization

(NATO) 5, 83, 86, 119, 172, 180, 182, 186-8, 194, 196, 202-9, 214-5

Nye, J. 81, 179
Obama, B. 118, 195

O'Connor, J. 121-2, 125

Offe, C. 31

oil 93, 111, 115, 119-20, 124, 138, 176, $185,192-3,196,211-2$

oligarchy $10,18,51,95,120,183,211$, 214

Organisation for Economic Co-operation and Development (OECD) 18, 102, $108,116,163$

Organization of the Petroleum Exporting Countries (OPEC) 115, 124,

Ottoman Empire 111

Overbeek, H. 66, 69, 95

Pakistan 198-9

Panitch, L. 11, 13

parapolitics 48

Partnership for Peace (PFP) 187

Pashukanis, E. 55-6

Pax Americana 4, 115

Peet, R. 77, 99-100, 114-5

Pento, M. G. 129, 138, 191

permissive environment 5, 210

Persian Gulf 111, 136, 181, 198, 211

Petras, J. 11, 57, 151, 169

petrodollar 119-21. 144, 176, 182, 192-3, 199-202, 208, 211-12

Pettifor, A. 108, 131-2

Picciotto, S. 20, 64, 77-8

Piketty, T. 183

Plehwe, D. 65-7, 94

pluralism $10,29,86$

Poland 157, 188, 207

post-Marxism 24

postmodernism 29, 178

Postone, M. 15, 27, 30-2, 35, 37-8, 89,

poststructuralism 28-9

Poulantzas, N. 92, 94

poverty $25,36,60,116,131$ 167-9; 'poverty capitalism' 144

Prasad, E. S. 137-8, 142, 152, 172

praxis $25,27,88$

proletarianization $51,71,183$

Proudhon, P-J. 25-6

Prussia 117-8

Putin, V. 194, 207-8, 211

Qatar 199, 202

quantitative easing 106, 155, 176, 193, 211

Ransel, V. 52

Rawls, J. 82 


\section{Index}

Reagan, R. 125

realism $10,15,29-30,45,81,87-8,117$, 146, 172, 183-4, 191, 210, 213

Realpolitik 82, 175, 205

regionalism 3, 17, 98, 114, 145-51

Reifer, T. E. 69-70

religion 8,30

renminbi 143, 166, 176, 182, 191

reserve currency diversification 105, 121, $143,163,175-6,182,210,212$

Reus-Smit, C. 6, 88

Reuten, G. 11

Rickards, J. 17, 97, 118, 137-8, 140, 182, 198, 200-1

Robinson, W. I. 3, 12, 19, 24, 50, 92-5, 169

Roemer, J. 26

Roosevelt, F. D. 114

Rosamond, B. 84

Rosenau, J. N. 10, 81

Rothkopf, D. J. 97

Rousseau, J-J. 85

Ruggie, J. 209

Ruhrgas 207

Russia 1, 3, 5-6, 14, 16, 21, 75, 105, 119, 127-8, 138-40, 143, 146, 152, 154-5, $157,162-3,171-2 ; 175-81$, as counterhegemonic power 189-202; energy strategy 211-12; energy trade with China 192; national security strategy 194; relations with China in SCO 1992, 195; policy towards Ukraine 75, 146, 179; role in Syrian crisis 199-202; US-Russian relations $175-81$

Saad-Filho, A. 168

Saudi Arabia 5, 124, 138, 157, 180-1, 193, 198-9, 202, 211-12

Schmied-Kowarzik, W. 27

Schmitt, C. $14,17,48,73,80,87,117-8$, 183

Scholte, J. A. 82

Scott, J. 19, 50, 63, 89

Sechin, I. 202

Second World War 15, 109, 114, 124, 2001

securitization $4,7,13,65,108,118,129$, 133,172

September 112001 (9/11) 4, 119

Serbia 206

shadow banking 41

Shanghai Cooperation Organization

(SCO) 185, 192-201, 214
Shia energy bloc 199

Slaughter, A-M. 10

social democracy 51, 167

socialism $30-1,67,79$

Soederberg, S.

soft balancing 5, 187, 191

soft power 169, 177-9, 188, 202

South Africa 1, 92, 161

South-East Asia 141-2, 148, 154, 184, 189, 214; financial integration 165-6

South Korea 69, 143, 151-2, 157, 161, 165

South-South cooperation 146, 158, 170

sovereignty $1,4,7,10,12,14-5,18$, 22-8, 44-5, 47-56, 60-1, 69, 72, 76-8, $82-4,86,89,91,95,99,102,108,118$, 123, 137, 168, 178, 197, 201, 204, 208; see also capitalist sovereignty

Soviet Union 5, 31, 49, 55, 66, 79, 97 , $111,114,196-7$

Special Drawing Right (SDR) 76, 97, 137,

Spykman, N. 184

Sri Lanka 198

Stalin, J. 154

Starosta, G. 38, 72

state theory $44,48,56,65,77,112,114$, 213;

statism 145,169

Stiegler, B. 1, 7, 40, 46, 71, 108

Straits of Hormuz 215

Suarez-Villa, L. 70, 95,

supranationalism 79-81, 83-4, 90, 98, 104, 107,

Swanström, N. 194-5

Sweezy, D. 112

synarchy 3, 23, 97, 99

Syria 21, 176, 189, 199-202, 211

Taiwan 161, 191

Tännsjö, T. 83

Telò, M. 7, 145-6

terrorism 116, 162, 196

Thailand 139, 161

Therborn, G. 186

Transatlantic Trade and Investment Partnership (TTIP)

transnational capitalist class $50,65,72$, 91-3, 110, 161, 176-7, 193

Transpacific Partnership (TPP) 72, 98, 172

Treaty of Versailles 113

Trotsky, L. D. 153-5, 160

Tselichtchev, I. 6 
Turkey 114, 155, 157, 161

Turkmenistan 195

Ukraine $6,75,146,176,179-81,187-8$

Ulfkotte, U. 206

unipolarity $4-5,10,14,177,180,195$, 200

United Kingdom 70-1, 111, 128-32, 135-40, 152, 157, 160, 163, 166, 175-6, 179-83, 186-7, 189, 202-5, 209, 212

United Nations 86, 201

United States 2-6, 10, 13, 16-7, 49-51, $53,57,63,69-72,92-3,97-8,113-5$, 119-21, 152-4, 175-89; attempts to isolate Russia 75, 146, 179, 207-8; foreign policy 4-5, 24, 57, 146, 171, 176, 182, 208; hegemony 16-7, 56, 69, $92,103,147,180,188,213$; influence of military-industrial complex in 120 ; permanent war preparedness 109, 113, 124; relations with Europe 181-9; US dollar 15, 75, 97, 114, 118-21, 124, 137, 129, 136-9, 143-4, 163, 165, 170-2, 175-7, 180, 182, 189-93, 198-204, 208, 210-11

USSR (see Soviet Union)

valorization (capital) 2, 7, 12-3, 20, 24-5, $30,34,36,40-3,52-3,62,55,107$, $110,123,126,129,133-5,212$

value form $1,11,13,36,43,47,54,95$, 108,110

Van der Pijl, K. 20, 25, 66, 69, 111

Veblen, T. 19, 50-1, 58-60

Veltmeyer, H. 11, 151
Venezuela 171, 176, 189

Vestergaard, J. 96-7

Volcker, P. 124-6, 189

Wagner, P. 29

Wallerstein, I. 5, 11-12, 14, 37, 48, 59, 110,128

Walton, C. D. $184-5$

Waltz, K. 4

Washington consensus $164,7,24,142$, 146, 151, 162-7, 172, 189, 192, 201

Weirich, P. 187

Wendt, A. 72, 85-9

Westra, R. 12, 21, 28, 51, 53, 57, 64, 70, $91,116,126-7.134,142,151,190$

Willie, J. 139

Wilson, D. W. 26

Wilson, E. 4, 13, 48-9

Winiecki, J. 129

Wood, E. M. 43

World Bank 98, 102, 114-5, 156-8, 161-2, 164, 167, 173, 201

World Democracy Forum 197

World Economic Forum 93

world state $78-91$

Wylde, C. 146, 165-8

Xiaoping, D. 180

Xinbo, W. 4

Yanukovych, V. 202

Yiwei, W. 190

Yugoslavia 214

Zakaria, F. 4, 6, 210

Žižek, S. 51 


\section{$\because$ \\ eBooks}

Taylor \&

Francis

eBooks

\section{from Taylor \& Francis}

Helping you to choose the right eBooks for your Library

Add to your library's digital collection today with Taylor \& Francis eBooks. We have over 50,000 eBooks in the Humanities, Social Sciences, Behavioural Sciences, Built Environment and Law, from leading imprints, including Routledge, Focal Press and Psychology Press.

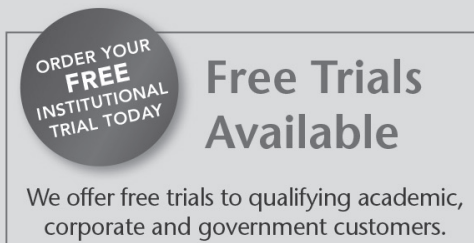

\section{corporate and government customers.}

\section{eCollections}

Choose from 20 different subject eCollections, including:

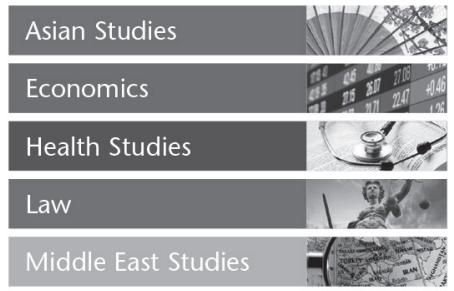

Choose from a range of subject packages or create your own!

\section{Benefits for you}

- Free MARC records

- COUNTER-compliant usage statistics

- Flexible purchase and pricing options

- $70 \%$ approx of our eBooks are now DRM-free.

\section{Benefits for your user}

- Off-site, anytime access via Athens or referring URL

- Print or copy pages or chapters

- Full content search

- Bookmark, highlight and annotate text

- Access to thousands of pages of quality research at the click of a button.

\section{eFocus}

We have 16 cutting-edge interdisciplinary collections, including:

\begin{tabular}{l} 
Development Studies \\
\hline The Environment \\
Islam \\
Korea \\
\hline Urban Studies
\end{tabular}

For more information, pricing enquiries or to order a free trial, please contact your local sales team:

UK/Rest of World: online.sales@tandf.co.uk USA/Canada/Latin America: e-reference@taylorandfrancis.com East/Southeast Asia: martin.jack@tandf.com.sg India: journalsales@tandfindia.com

www.tandfebooks.com 



